\title{
IMPROVED METHODS \\ $-\mathrm{CF}-$ \\ Corn Growing and Intense Cultivation
}

\author{
BY \\ J. B. ARMSTRONG, \\ SHENANDOAH, IOWA
}

\section{SB \\ 191 \\ Mratia}




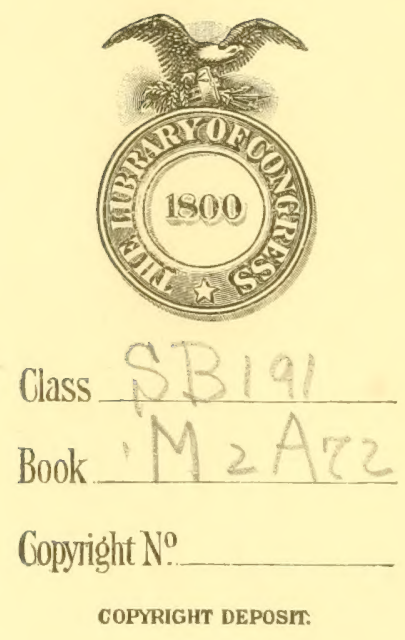





"Some qualities Nature carefully fixes and transmits but some, and those the finer, she exhales with the breath of the individual as too costly to perpetuate. But I notice also that they may become fixed and permanent in any stock, by painting and repainting them on erery individual, until at last Nature adopts them and bakes them into her porcelain." -EMERSON.

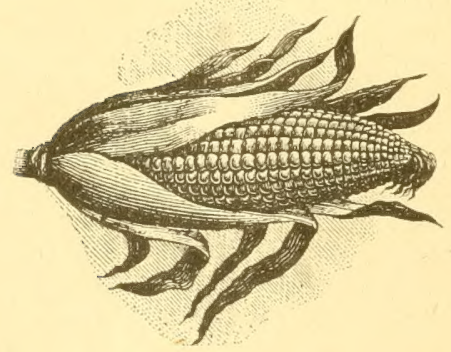


IImproved sisetboos of Corn Growing and Intense Cultínation

\author{
By J. B. ARMSTRONG.
}




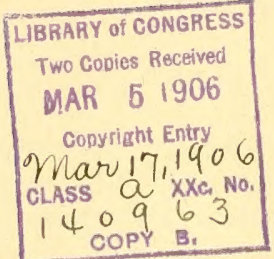

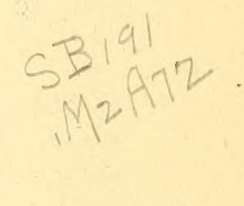



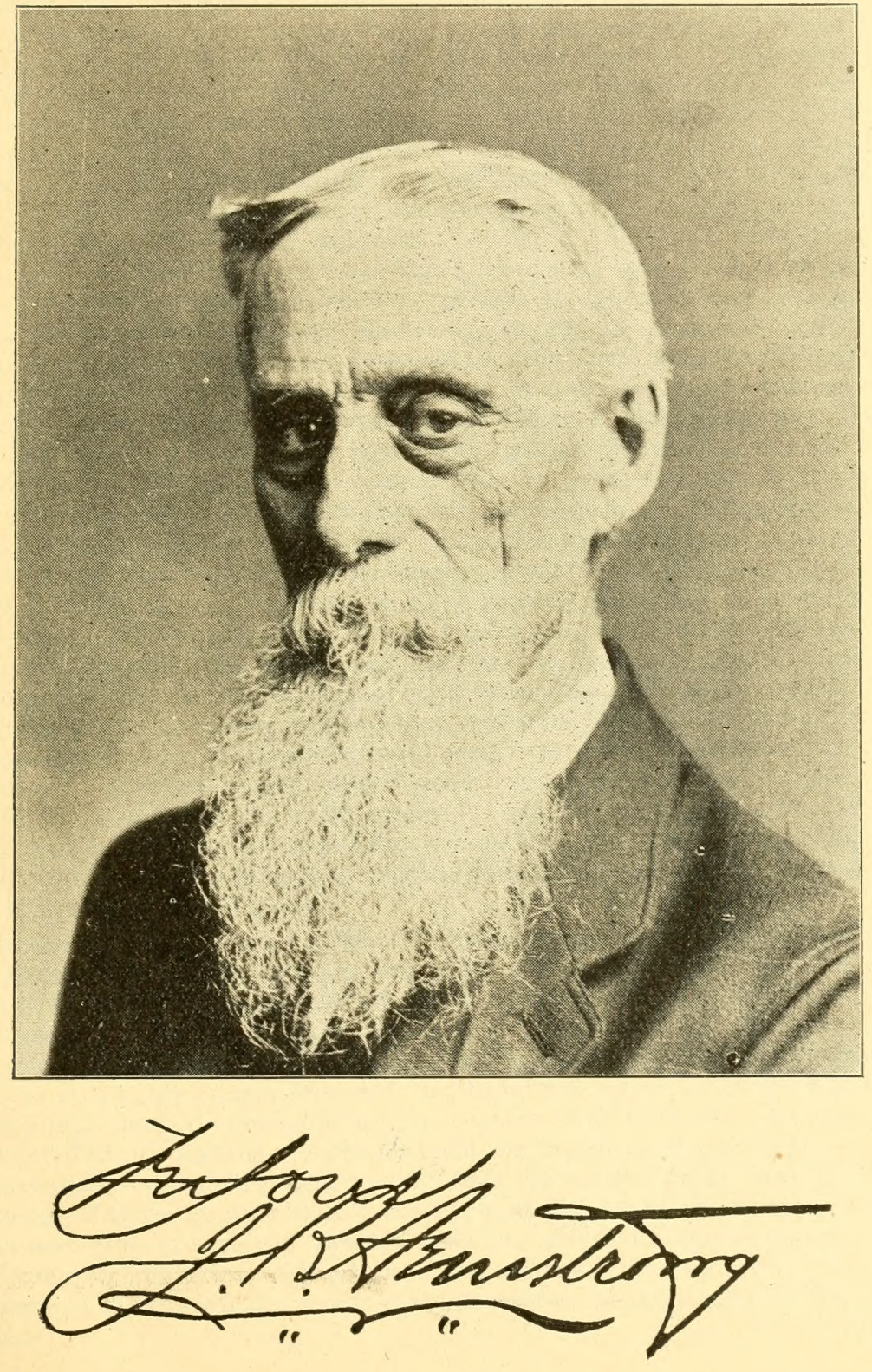



\section{TO THE FARMER, THE FEEDER AND THE BREEDER}

For the past sixty years it has been my lot to be a farmer and connected intimately and very much interested in farm life. T have lived to see the sickle, the cradle and the scythe, the only tools for gathering grain and hay in our New England Home give way to modern machinery. I have watched with interest the strides made by agriculture in its progress to the West. I have seen the great changes from the simple methors and simple life with its few wants that were easily supplied by new and cheap land and few if any taxes. I have farmed on the hilly clay and stone coverel hills of New England. I have made farms of many thousand acres of the virgin soil of the prairies of Illinois, Iowa and Nebraska, therefore think I am competent to give advice on Farming. But those days have passed, farm life has changed, there are no more cheap lands and the farmers of the past must awaken to the fact that he must have more knowledge in rerard to new methods and new uses, that he may be better prepared to grow such crops as will pay interest on higher priced land and give him a fair margin. The masses are waking up new problems. confront them and all other vocations of life. They must and will be met and I trust the farmer will be the last one who will get discouraged. For him the government has at great expense established agricultural schools with teachers who are learned in all that pertains to crops, soils and adaptability and each individual state has her schools working along the same lines and on the same subjects and the farm paper is a welcome visitor at your door each week, bringing you all the latest items in regard to the farmer or his family and finally we come down to the farmers institutes, being held for the farmer and by the farmer. ()ught there be anything discouraging to the farmer or to farm life? We see no reason for discouragement in the new problem that confronts him. There are no other callings so promising as farm life and especially have the farmers of the great corn belt region of our cuuntry good reason to take new courage and stay by the farm. Bat, never before has it been necessary for the farmer to study farming in all its hearings from a practical standpoint, so carefully as at the present day and at no time has he been so much interested in the subject of farming as he is today.

In casting around for a practical treatise on the subject I have been unable to find a book that seemed to the point and so condensed that it would seem to be just what the farmer wanted. I have for several years issued a small paper, The Farmers' Guide and a book on corn growing that have met with great favor amongst the farming people. I have been urged for several years to give to my f urmer brothers the beaefit of my experience, I have in my business connection been brought in contact with farmers in all parts of the United States and for their be selit and the farming world at large I have consented to write this volume, giving them iny best throughts and the best teachings of those wh" are high in the agricultural learning and if as I wish I may help give light on the subject I will be satisfed and my object will have been accomplished. I trust those who may read this book will criticize the same in the spirit and thought that prompted me to bring it before the people. 


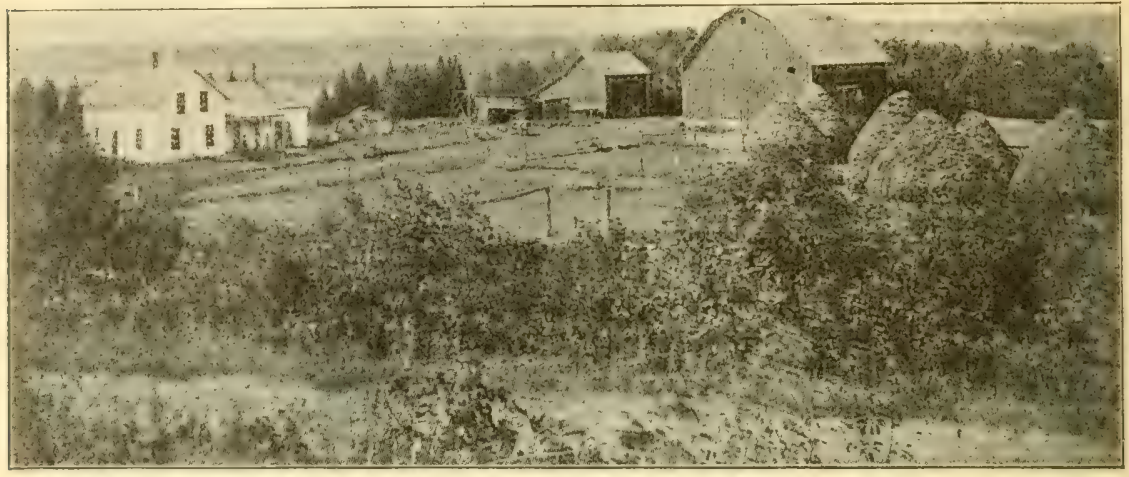

\section{Do Not Sell the Farm}

One can hardly read the above heading without a feeling of sadness With the American people there seems to be born an unrest; a longing to do something or go to some place which if they wished they could not describe and too often we find the farmer who in his younger days, by hard toil or in substance left from his father's estate has gotten together money enough to make the first payment on an unimproved farm, on which himself and his young wife are starting out together to meet the pleasures and sorrows of life, and in their efforts to improve their new home and care for the little ones, years have past, great changes have come of which they took little notice, being mostly interested in clearing away the farm mortgage. Iears roll on, a season of depression is at hand, the wife is over taxed with care and nearly ready to give out, then is it any wonder that the farmer is blue? He sees his neighbor in his fine carriage, with his family seemingly enjoying life ane luxuries. It is no wonder then that when the city real estate man proposes to sell his farm at a great advance that his first conclusion shall be, we will sell the farm and get out of debt and try to live a more easy life. The above experiences comes yearly to thousands of farmers of our nation. How many object lessons they may find each day in any town or city. The poor day laborer, trying by hard work for any wages he may be able to get to clothe and feed his family of little ones. His wife washing or doing such work as she may have to help along. Many such wrecks may be found at all times. The farmer that did not stop to think has sold the farm. Today that same family muurned the loss of their on se happy home. That same farm today is worth many times the value of which it was sold. The owner is today enjoying the improvements they had made, and fruit from the trees that they had planted, all of waich was lost to them through the lack of stopping to consider the question of selling the farm. A farm, depend ou it, is a gift frcm the gods and the time is fast approaching when the farmer will see it. He should not be discontented, he should be cheerfully patient, conditions are most assuredly going to change and he will then discover what wealth he had right before his eyes and in his own possession a claim, staked and fenced, whose giold is not only inexhaustable but sure, a claim, better by far than one of the Klondike or India. There is an ola saying derived from the experience of a man in dealing with the ups and downs of life, during thou- 
sands of years which says that all things comes to him who waits. If the farmer doubts the truth of the old proverb, let him cut it out and put it into his pocketbook The time is coming when he will find it to be true, and the truth will lie beside it in great big bank bills. God's greatest blessing to the average farmer is a farm. Let us entreat of you that you do not forget the advice we give. If you have the farm, be it ever so small, keep it. The time will come when mosi needed that the farm will keep you and yours in happiness and comfort. Therefore, do not sell the farm.

In support of our assertion that the great change is coming, we may state the fact that $\$ 500$ per acre has been paid for farm lands in England and the land has paid the interest of that country on the investment. Today when we note the fact of the great rate at which our naition is multiplying and the hunger manifested by her people for land, take the "Rosebud" land as an object lesson, where thousands were turned away who could not get a farm in that reservation. Then stop to consider the fact that our agricultural land cannot be enlarged, that the increase of population will double in say, ten to twenty years. Can we not reasonably be sure that by giving our farms the same care and attention that they will bring even more than that of England, or any other land on the face of the globe, and especially is this true of the great surplus growing states. Absolutely every acre of it is growing corn, the acreage cannot be enlarged, the consumption of corn is doubling fast. Is it then any wonder that the man with the corn farm is master of the situation? Corn is king, lucky the man who owns and controls a few acres, he and his family are honorable members for life for his kingdom. Then our advice and your judgment would lead you to secure land, treat it fairly, reap the rewards, which says come to him who waits.

\section{The Farmers' Sons and Daughters}

To the coming generation of farmers and to the agricultural world and to the prosperity of our nation is the great question of what shall be the life work of the farmers' sons and daughters. Upon their choice depends in a great measure the welfare and prosperity of our American people and in this article I wish to bring to their attention, the opportunities that today are offered to them by our great schools of Agriculture which are being so fully supported by the great government of the United States and each individual state where all the practical knowledge and experiments are being taught and demonstrated so vividly and truly and where the student is brought so close to nature and its possibilities tnat at once he becomes thoroughly imbued with his work and the possilities that he turns the fiction and dross of the world down for farm life and pleasures of agriculture, forgetting the perplexing turmoil of the professional life of those in town and city and takes for himself the highest and most pleasant profession offered to man-Agriculture. The first question therefore to settle in your mind is, does farming and things pertaining to the farm appeal to you? Do you enjoy the freedom and independence of the farm life? If you can answer these inquiries in the affirmative then I think I have something to say to you about your life's work and determining your profession, which is a question every young man has to settle for himself sooner or later. The successful solution of this important and often intricate problem will largely determine your future useful. ness. You have grown up on the farm, and, I venture there are not many things which come in the ordinary routine of farm work but what you pride 
yourself on being able to do. Therefore, why are you not better fitted to take up the study of a business you already know something about rather than jumping into something you know practically nothing about, but simply think you would like when you once got onto it. One surely makes a mistake in going into something for which they are not fitted. There is no question but that farming is a paying proposition, if run on business principles.

The average farmer is not raising anything like the crops he should. The avera cre corn yield for United States, per acre, does not reach the 35 . bushel mark. Wheat has been condemned as a non-paying crop and dropped from the rotation by many, if rotation is practiced at all. The silo and green crops for soiling are given practically little consideration and scrubby mongrel animals make up the live stock outlay on only too many farms. Would you like to do your part in putting farming on a better basis in yourcommunity?

There is always a market for the best. But without good training how can you expect to produce the best? Iou simply cannot, and you will find you have to "lay down" to the fellow wh) does known now. If you are hunting a profession that offers you an opening and a chance to "make good" then look into agriculture. There is no course now offered to young men which can compare with it in advantages and earnin $\pi$ capacity of its graduates. For example, take this year's graduating class at one of our leading Asriculture Colleges, nine in number (there should have been fifty-nine). Four of these agricultural graduates went back to the farm, the best place to apply their education The other five have good positions elsewhere: one is in the government experiment station: another has a responsible position in the dairy department at the World's Fair: another is assistant farm manager for a millionaire farmer in New York: another is dairy foreman for the same man, and the other is a partner with his father in the fertilizing business. Remember, this is just one year's class from one school.

Prof. H. C. Price, dean of the Ohio college of agriculture in an article in the North American Farmer on the "Opportunities of the agriculturally trained man," says that "among the graduates of the college of agriculture of the ()hio state university who bave graduated in the last eight years are five men who are holding full professorships in leading colleges at a salary of $\$ 2,000$ or more per anum: in the Cnited States department of agriculture there are between fifteen and twenty of our recent graduates who are holding positions with salaries ransing from $\$ 1000$ to $\$ 1500$ per year." Now, if you think your preferences do not lead you back to the farm, how can you in the face of the above examples, and numerous others equally convincing, piunge into the ordinary professions, which are now already overcrowded with their burden of novices, and ignore a field which more than any other offers to the ambitious young man a career of honor and usefulness? Wake up, fellows, to a grood thing! People are coming to realize that there is something really worth while in scientific agriculture and you can see for yourself, when it comes to the "show down" that the agriculturally trained man has hold of a mighty good string.

'The farmers' son, of all young men, have the qualitities first of being a strong, healthy mind, clear judgment, the early thought and training from his parents who are in full sympathy of this line of life work-this combined with the teachings of the Great Bureau of Agriculture at Washington D. C. and 
and the state Experimental stations and the great awaking interest of the people who will, at no distant day demand that the teachers of our public schools shall be competent to teach the same at our public schools when in a crude way they shall be a testing garden, that shall be of great interest to all our boys and girls, then will their minds be stored with such knowledge as will make farming and the farm home the highest ambition and make their lives useful and happy.

\section{Thoughts for the Father and Mother on the Farm-Intelligence and Profitable Farm Knowledge}

As individuals our knowledge is very limited, but when we think that every progressive farmer, feeder and breeder is a student in that greatest of all schools "the school of experience" and that, to many of these students there comes some special task that puts him, or her, as it may be; upon their metal and they successfully work out the problem and wr te out the facts for one of the journals, the concentration of the indivual information reaching millions of eager readers searching for this very knowledge, that will be found in this volume. Nuch of the correspendence is from the level-headed, close observing men who guide the plow, put out the feed and mate breeding stock. Thus these journals become bulletin boards describing facts that may be relied upon.

The greatest experiment station in the world is the Department of Agriculture of Washington D. C. It has behind it the richest and most progressive nation in the world.

Then the several state experiment stations that study soils and condition pertaining to each state. In this work is an army of the b-st trained specialists and not a weekly issue that does not have a record of some triumph "of mind, over matter" how to destroy moulds, rusts, scab fungi and insect pests; they show us lessons in better breeding. Tne students that guide the plow and work in the feed lots and manage the breeding are of the primary class. The experiment station experts are the intermediate. The wizards of the magnifying glass, the microscope and the chemical laboratory are of the "high schoo." 'They tell us of protoplasm; a name not one farmer in ten thousand ever heard pronounced or saw in print, yet it stands for a quality in every living thing and if it were to be destroyed in vegetable life every living creature would soon perish by starvation.

They tell us how in protoplasm is developed the cell that later becomes impregnated with the vital spark we call life, and in the vegetable or plant world there is born from and of this protoplasm countless myriads of a vegetable growth so small that millions of separate organisms can exist in an inch of soil. This growth called bacteria affects for good or bad every bite of our food, every swallow of liquid: without the work of bacteria in our soil our field; would become barren. These deeply learned men prove to us that in or that as part of the atmosphere over every acre of soil there is fertilizing material that our soils are in most need of, nitrogen to the amount of 36,000 tons (nitrogen, pure, is worth $\$ 300$ per ton) or over each acre the nitrogen is worth $\$ 11,000,000$ yet our crops starve for nitrogen. These things are but as drops of water to the ocean of what these wise men tell us every week.

In 1890 a young man bought one of these supposed run down farms at the moderate price of $\$ 10$ per acre in a pleasant county and near a good town 
and shipping station. It was called the poorest farm in the county. In ten years or in 1902 the condition of the soil had been so changed and without a dollar being spent for commercial fertiltzers, and in ways any farmer, no matter how poor, can follow that it is now a first-class farm. This betterment of soil and conditions give this farm rank as one of the best in the country and an offer of $\$ 40$ per acre was refused. He made no substantial headway until he became an earnest student of soils and soil conditions. To help in his studies he bought the best books on farm subjects, he subscribed for a number of leading farm journals and became a zealous student of farm problems and their solution as taught in their columns. He found in every issue something worth many times the cost of the paper or book.

When he got so as to raise more than the work stock consumed, he found colts, calves, pigs and poultry would pay him sometimes double, often three times what shippers would pay. Then feeding journals were added: the need of better stock as a means of better results and breedtng journals were next added.

Without the wise counsel from the able editorials and light and encouragement from the correspondence in these books and journals he would have no doubt but that today he would belong to the army who believe farming doesnot pay. I know it does pay if you know how.

Now I want to teach a million farmers how to tap the great reservoir of riches-the air-and the inexhaustable mine of mineral wealth-the earthand combine this vast store of richness in the surface soil in the form of available plant food, why they are failing as I failed until I found out how to propagate and bring into existence the thousands of millions of bacteria and invisible organism that worked incessantly to help me.

I assume the right to teach in this great school, for I have caused three bushels of great big golden ears of corn to grow where was one before and more than two bushels of heavy wheat on the same land that used to bring but one bushel of lirht chaffy, shriveled wheat. I want to go with the vast army of farmers, feeders and breeders boldly up to the door of the temple of agricultural wisdom. A knock will admit us to the inhaustable store house of knowledge and each one of us, according to his zeal and intelligence, can take all he can use.

The civil laws and public sentiment now requires the lawyer, doctor and professional man to acquire an education in his work. The law of necessity is forcing the farmer and breeder to become a student. The failures upon the farm today are the result of ignorance. Success can only come of enlightenment; the shiftless drones in the hives of agricultural activities are being driven out. The experiment station bulletins and the farmers' institutes are schools of instruction brought to our doors every week. We have no excuse but indolence if we remain ignorant in the future; if we fail the fault is our own. We especially plead with the fathers and mothers upon the farms that they place these educational advantages within the reach of their children to the end that they may fit themselves to hold their own in the fiercer struggles of competition and crowded industries. In the days nearer to us than we think the educated, skilful food producers will have a decided advantage over any class of workers in the world. Failing to fit your sons and daughters for first place you must see them become servants, "hewers of wood and drawers of water" for the educated who will dignify farming as a 
profession. They will do their work with the brain, while your boys and girls toil with the hands.

\section{The Farmer and the Elements}

The farmer of all our workers is at the mercy of uncontrollable elements to a greater extent than any other of the great industries of our nation: the controlling element in his harvest is the physical condition of the soil. If the soil is not in condition to produce a good crop, no amount of labor can produce it. The farmer is at the mercy of the weather. An excess of deficiency of rainfull, an excess or deficiency of heat, determine more than anything else the yield of all kinds of grain. Given weather that will enable the farmer to put his land in proper physical condition and retain it, and there will be a great harvest. Given weather that will forbid this and the harvest will be small. In other words' the yield of the crops will depend not so much on the actual fertility of the soil, its content of potassium, phosphorus or nitrogen, as upon a physical condition that will enable the crops to use the amount of fertility therein contained.

Where lands are soggy, the weather cold, a good stand of corn can not be obtained, no matter how good the seed. Where the same conditions prevail neither wheat nor oats can yield a full crop, because weeds can grow in soil in a bad physical condition while grains can not. We mention this because we wish to impress upon the farmer that what he needs to be thinking about is not so much the chemistry of the soil as soil physics. He needs to study the best methods by which he can get all there is in the weather, so that he can utilize to the fullest extent what nature gives him in the way of heat and light and moisture. These are his raw materials. He can use them to the fullest extent to which they are supplied or he can waste them. If he gets his soil in the best physical condition, in the best tilth possible, where he can make the fullest use possible of the raw material which nature gives him, he will make a success; otherwise, failure is inevitable.

We do not like to see farmers paying too much attention to soil chemistry and spending too much of their money in buying commercial fertilizers. The chemist has his place and can be and is at times of great service. Commercial fertilizers have their place and can sometimes be used to advantage. But the ordinary father had better turn his attention to the best methods of keeping the soil in the very best physical condition, which can be done by rotation of crops, by the careful use of manure, by the use of the best implements available, by using his best knowledge and his best skill. Spend such spare time as he may have in reading some of the many farm papers in which he will find many new ideas, a rich food for sound thinking; again such reading being upon subjects that interest the wife, the sons and daughters, will greatly tend to fix their minds and attention in the right direction; will make them men and women of sound judgment, contented with home and nature in all its purity and comfort, satisfied with himself, his lot and the world; his life will be a happy one and his children a joy in his old age.

\section{A Model Farm}

No one would be so presumptuous as to estimate what will,be the ultimate population of the United States. This is a subject for:much interesting speculation. Some fear is even now felt that the limit of productivity in this country will soon be reached by reason of the rapid settlement of our 
waste and public lands. Nothing better shows how causeless this fear is and what great possibilities of further growth and development still remain to us, than a little pamphlet just issued by the department of agriculture, styled "A Model Farm."

This model farm is situted in a very old settled district in Southeastern Pennsylvania, near a large city and contaias only fifteen acres. Thirteen acres are under cultivation and the remaining two acres are occupied by buildings and surrounding yards. This little tract of land came to its present possessor in $1 \$<1$ with a mortgage of $\$: 00$ upon it. The first year the farm lacked \$ti of paying expenses. By careful management the owner within the next six years paid otf the entire mortgage and interest. That is, he macle $\$ 1,2010$ a year ofl his tifteen acres, and this sum is the annual net profit he has been setting aside ever since the debt was paid.

The methols which this farmer employed to bring about such successful results are worth the consideration of the whole agricultural world. The natural soll of this little farm is very poor, reddish gravelly clay. It was so run-down in 14,1 that it did not support the two cows and one horse kept upon it. Now it raises the roughness for thirty head of stock, serenteen of which are milch cows. The present remarkable state of fertility was brought about solely by the use of stable manure applied directly from the barn as it was produced. The method of handling the manure was such that none was lost, either liquid or sulid. ivo commercial fertilizers were purchased, and no manure was hauled from the city or from other places. The waste from the farm its $1 \mathrm{f}$, judiciously preserved and distributed, was used to bring the farm up to its present high state of productivity.

On assuming management of the farm, the owner read lvaincy's book on the soiling of cattle, published in 1.5,". "Soiling" consists in cutting and feeling green feed instead of allowing the animals to run on pasture. This practice the farmer adopted and carefully preserved all waste. The next year he read Stewart's book on feeding animals and earsed his first lesson in "balanced rations " He also learned to feed some dry hay with the soiling crops, thus giving the manure a proper consistency Th. nce forward the managrement of the constantly growing herd of cuws was a simple matter, and the farm began not only to pay a protit. but to iacrease in fertility. One man and a boy do the labor of the farm, except in hay harvest a ad during the cutting of silage. 'The owner does only such portions of the ordinary labor as he cannot safely trust to hired hands. but he paus all the work and sees that his plans are strictly followed. So systematic is the work that he often goes away fur weeks at a time without notice to his laborers. or interruption of the regular routine. He has plenty of time for rest and recreation. He pays no regard to rotation of crops. His remarkable success depends solely upon planting the right kind of crops, feeding his animals a balanced ration, preserving all manure and waste and protecting the farm from being washect out by the the torrential rains.

The lesson gained by this one man's success is that inferior lands can be matle to yield twice or three times as much as the present average by careful and intelligent husbandry. Such husbandry is not yet generally practiced by American farmers but eventually it will be practiced, and then there needs be no fear that the proluct of the farms will not keep pace with the growing population. 
From the above it is very evident that the population of our great Agricultural country may be increased to any number and yet the necessity of the people will be fully met by the more intense methods of farming and the hetter knowledge that we will have obtained in the methods of preserving and feeding what our farms will produce no nation or people ever had so many bright minds in such earnest work digging deeply into all hidden mysteries of nature which hold the combinations that will unlock the golden treasurers and double and thribble our yield and bring such plants and fruits from their hidden homes in far distant lands to be di-tributed by our Agricultural Associations to those parts of our great domain where they may be most at home or most needed and best adapted. But a few years ago it was thought that winter wheat could not be grown farther north than north Missouri and yet today it may be found growing luxuriously in Ninnesota and South Dakota, the same being true with corn while undoubterly in a tropical plant by the careful selection and breeding is baing grown as far north as North Dakota fruits the apple, peach, plum and cherry are fast making their home in the north, we have only to turn the attention of the thinking man or scientist to anything that will be for the good of the people and he will tind the means to obtain it while it is impossible for each farmer to keep lave with all these improvements as yet by occulying bis spare time in reading Agricultural Papers and Bulletins issued by different State Experimental stations of the different states, he will be well informed on all those subi scts and be able to select such things as shall seem best for himself or his ricinity: the amount of our avalabol farm lands is a fixed fact but our possibilities can not be estimated. Strive then to make your farm a model farm in your own way and with your own mina and means and by so doing you will be satistied witb yourself and the great world at large.

\section{A Twenty Acre Farm}

Reading an article on Page !10.- on the subject of "Land Hunger" prompts me to give the readers of the Farmer my experience on a twenty-acre farm. I came to this county fifteen years ago at the age of eighteen, having workel from twelve years of age until eighteen to save enough money to bay a ticket from S sitzerland to Kansas. I worked out on a farm by the month at from \$1; to $\$ 20$ and went to school a little while in Lincoln. Then I started back to Swityerland with $\$ 10$ which I had saved to visit my p irents and help them secure a home. I stayed in swityerland seven montbs, and went back to Kan. sas again with only $\$ 2.2$. I rented a farm of $1: 0$ acres, married in the spring of $18: \%$, started at the bottom, bought everything on time, and gave half of the crops for rent. The first year's work p zid my debts. The second year I came out $\$ 270$ ahead, which gave me money enough to rent an eighty-acre farm and pay cash rent. But I did not do tbis. I was raised on a six-acre farm in my native couatry and I thought twenty acres would do in this country, so I found a rough piece of land in Pawnee county, Nebraska, for which I paid $\$ 12.50$ per acre. The land next to it sold at from $\$ 4 n$ to $\$ 50$, but this twenty was rough hill land. corered with brush, springs and rocks. The neighbors there wondered what I was going to do with a piece of land like that, but the more they talked the more I determined to show them what could be done. Today many of them say "He makes as much on his twenty acres as we do on our large farm."

What do I raise: Well, potatoes are my money making crop, and small 
fruit. I have about five acres of potatoes every year and from eight to ten acres of corn. I grow corn between the pot atoes and small fruit in the young orchard. I put out an orchard of 950 pears, 500 peaches, 100 plums, cherries, apples, quinces and every kind of small fruit that will grow here. There is always something ripe from the 20th of May until October. Always have something to sell which brings ready cash, and there is always something to do.

About the pears: I put out thirty-six the first year of the different standard varieties. I put them on the north slope where the timber growth was hickory, oak and walnut. Those trees all have tap roots and I pulled some of them out from six to ten feet in length. It is a loamy soil, twenty-two feet deep, and after a rain the land is dried first, therefore I can cultivate it first and let the air in and hold the moisture. On the south slope I let the timber stand. Here I have a spring and nice pasture for two cows and a good protection against heavy winds. That is the true place for a pear orchard. We must study the location, the soil, the tree and its wants if we succeed in prospering in growing it. I have places on my farm where I could not grow trees. Above the pearorchard is about an acre that is wet, which is not fit for corn nor potatoes nor grain nor the small fruit. Sometimes it is not fit for pasture. I made two ditches and filled them with rocks to drain the land and made a reservoir of twelve hundred barrels to save the water. I sowed this piece of ground in English blue grass and red top and it makes a lot of feed and good pasture. The water. Luse for irrigation in dry weather.

But I have found something better than watering my crops. Wealways get enough rain if we take proper care of it. This is my experience the last six years in working a small farm. Cultiration will do it. Not simply cultivation to kill the weeds. hut cultivation so that weeds won't grow. Cultivate the potatoes as long as the vines are green, but do not cut the roots. Cultivate the corn as long as it grows. Do not quit when the tassels appear, but keep on with five or eight shovel-cultivator. That is the time to add bushels to the acre, and these extra bushels make you money which will help you pay off debts and have better homes and be better satisfied. It is not the acres we plant but what we take proper care of, and this can be done on a small farm, and there is where the money lies, having everything under control no matter what the season. I would rather wait on the train than hare the train wait on me, and the same stands good with the crops. We must wait on them and not have them wait on us. From five to eight hours after the rain we can make a good soil mulch and get the best results and save the farm most effectively. If a man has fifty or sixty acres of corn how can he expect that the corn plowed at once after it when the best mulch can be made? Where the plowing has been delayed a crust forms on top and the air will be shut out and the moisture will evaporate rapidly. The roots will grow and the root system will come close to the surface. This is true in any cultivated crop. It is hard on the young orchard to let the crust form, especially hard on pears.

The pear is one of the most thrifty growing trees we have. In 1901, that dry year, I planted 350 and lost only three trees out of 312 where the ground was continuously cultivated, and thirty-six trees which were planted in a clover field and could not be cultivated. We kept a good soil mulch around these latter trees, put hay around them and watered them, but I lost half of them after the clover was taken off the ground. Where I cultivated I had a 
mulch all over the ground and some of the trees bloomed and fruited the same year and have fruited right along ever since. The leaves of the trees in the clover tield besan to look yellow, then black, and soon the limbs anil stems died They could not withstand the heat of the day because of lack of air and moisture for the roots. In 1902 [ put out $4,0 \mathrm{~m}$ ore. H'ear trees planted in 1898 have from one-half to one bushel of fruit to the tree. When I commenced to plant the pears the folks here said that they were not grood--that they bighted. They said I would never see any fruit from 1 hem, that my mon. $y$ was lost. Now they see different. Everybody makcs some failures, but fa lures are worth doilars and cents to us in our future work. They teach us how to become masters of a thing instead of slaves. Mlust of our young men today need a better education and need to get it as they go along in practical work. Five young men went from our township to llatiot $\_$for land. We have plenty of land here for them if they wanted to work. I have a twenty acre farm, and it is enough for any man who will work it right.

Tne above is from the pen of one of our adopted brothers, from a foreign land, so different from ours where in the crowded condition of population of necessity their farms must be small and the farming done in an iutensive manner and such care taken as to seed selection and cultivation and erery fot growing something, their holdings of course being small the farm $r$ is able to, each day, inspect every rod, his habits of care and industry make a good living on those very few acres and when such a farmer brought to our nation and on to our rich prairie where it seems to him one bas only to scratch the suil and it brings forth sucn crops of golden produce that twenty acres seems to him an immense farm. He puts the same methods, the same care and attention as he did in his own country and the results are most wonderful We have in mind an Fuglishman farmer who many years ago sett'ed nearGalesburg, Illinois. At that time land was very cheap, he possessed some means hut only brught forty acres, that being twice the amount he had had to work in England and to him the forty acres was a large tract. His methods were very much like those stated above, although he had turned bis attention more to cattle and hogs For many years his only land was that forty where all his time and attention were spent and until he had accumulat d money that he could not let for a good interest he did not buy or own any other land, b.t final'y for the purpose of employing his money safely he bought more. He often said to the writer, "The forty is all I can attend to as I ought" The small farm well attended brings wealth, bappiness and comfort and the great respect of all our friends. We may learn many valuable lessons by observation of these foreign brothers, who have been forced by circumstances to conform to such rules and such economy as shall bring the greatest results to any nation or people.

J. B. ARMStrong.

\section{The Farmer of the Past And the Farmer of Today}

A few years agro I visited my old Michigan home on a heautiful August morning when I took a stroll out from our native town duwn past the old c metery where so often in our boyhood days we were called to sympathize with our dear friends as their loved ones were being taken to their last resting place and where later in life we laid our dear parents. This was one of those days so bright, so still, so quiet that nature could talk to us in a language none but ourselves could understand and as I passed along and around the old farm where so many of my happy days werespent, all of those bygone 
frien Is, in wr m nd, came trooping up to give us a hearty cheer. Can you wond $r$ that I began to meditate upon the past and as I seated myself upon the $t$ unk of one of those mighty monarchs of the forest under whose branch s ve had often played and chatted with our young friends in days long past? A feeling of sadness came over us, the birds were singing just as mirrily, th: suil was shining just as brightly, all nature was in its beauty, but the companions of our youth were not there, the bright faces, the laughingr eye's and friendly greeting could not be, alas where are they and the farm so chanved? In those days much of it was heavy timber, sixty years ago and [ could only think of the toil and labor that our friend bad done to fell those mirhty trees and put in cultivation those baautiful lands. We were with him in his dirs of strength and toil, his pleasures and sorrows and years ago he passed wo tne other side. Today it is all highly improved, nothing being left but occuinaily an old stump or decaying body to show i s past condition, all mak wy a hug: reminder of the past: as I sat there no sourd reached my ears and I could only realize that as its being typical of the past. Did it erer oc. cur tu you that noise and the kind of noise was a sure index of our advancement :ud progress in farming as well as in manufacturing? About the only noise on the farm in those days was the spinning wheel and loom or the happy ld'sh of the maid as she went out and harkened for the tinkle of the hell : n old brind.e who was peacefully feeding far away amongst the mighty trees and beautiful pasture. There were no moxers, thrashers or engines upun the furm. no modern sewing macbines in the house, no typewriters in the offic. We realize that many many years have past since those days; no other dzys can b? as happ, but with their passing most of our young companions have gone. The days of pioneering are mostly past. Our grandfathers have sublued the mighty forest and made them to blossom as the rose and provided for us, beautiful homes. They too have gone to their eternal rum and we are left to carry on acd improve upon the work left for us. Th.irs wa a life of hardship, lahor and toil: they accepted it cheerfully and did it fithfully and well and the man must indeed be an ingrate whodoes not feel anı $r$ 'coru $\%$ the fact that they made all far more-pleasant for us. They laid th. finmulion and well tou and we have entered upon the building proper. Perhaps only upon the first story but I realize that we must so build on their fommitim that our children shall not be ashamed of cur part of the luilit nw w w the great structure shall tave been finished and let us not forget that we each and all are workers and upon us lepends the solidity and charwer of this mighty structure. We realize today as never before that the farmer is the foundation of all our greatness and yet with all our thinking, wrisms anl experimenting, we still find many that are a chip of the old b.uik initeat of being as they ought, the grand old block with the addition of a new ch 1): we 1 rust that every young man who realizes bis present opportunitios s.h adrantages will try and be a greater and if possible a better $\mathrm{m}$ in tha $\mathrm{w}$ his father in all respects. The farmer of today ought to be more libsally $\cdots$ lu : ited along the line of his special work, that includes more than h) k-learnin'. It requires brain-power more than physical, which will be in demand n the future. He should not be worked so hard that his mental and moral factiti.s may grow and enlarge and be the dominant character of his being. He sionic be familiar with botany that he may intelligently observe the hits of the plants, trees and shrubs and be able to classify annuals, bicunial a.r p prenuial. He should know enough of zoology to be able to judge 
correctly of the use and injures of birds, worms and insects; he should know enough of geology and solid chemistry to distinguish the effect of intense farming and soil robbing; he shculd be, above all, a Christian gentleman at home, in the field, the garden, the orchard, or lawn as well as well as the library. "Does it pay tinancially?" has been the great question of the past: the same questions are before us today: "D jes it pay to be like our fatbers: does it pay to bəa fine and cultured f'hristi an gentleman; do?s it pay to be at home at all time, in the field or with the cultured gentleman you meet from other parts of our great land?" These questions are being auswered every day by the great progress of our mighty nation. Today, y,u may observe on every hill top magnificently grand edifices of learning, where the poor have the same rights and privileges as the rich, where the lowly street Arab may prepare himself if he choose, for the highest honors in the gift of our people. We have now arrived at the point that we must have a better grade of live-stock, a more productive variety of grains, a better quality of fruits and vegetables, more perfect machinery, hetter appliances in all directions, for all will be in great flemand. The old methods cannot suplly: they will not do. All products the farmer has to sell must come to market in an attractive package or form, put up by clean hands and honest weight to receive the highest price. Agrain I wish to say a few words, that it has been our observation in traveling over our country that where we tind the best clothed and fed people, the best land, the greatest number of churches we find the most contented and happy people. Can you imagine what the bearing upon life may be in the beautifying of our homes and grouncis: will they not appeal to our preceptive faculties, to our artistic nature? If so. do not huild a house so large that you cannot alford to paint and adorn it: never hare so large a farm that you cannot have a finely cared for lawn. Such are great object lessons for the good of all. How many of your neighbors will follow your example, how soon will your street be beautiful if your eftorts are in the right direction? I Irust this tidiness will soon sweep over Iowa and that we soon shall see ease, comfort and happiness in all directions. The farmer of all these should have a clear power of observation so that he may readily appreciate and apply nature's laws. Lpon his shoulders rest all our prosperity and until the farmers of our natian are progressive to the highest degree our country cannot attain that eminence we so much desire.

Let each farmer devote all spare time in stuying nature in all its forms and follow our sugrgestions as nearly as possible and he will he able to observe and comprehend many things connected with nature laws which otherwise he would have passed by unobserved. Therefore, let us be thoughtful, industrious and earnest so that those wh) are to take our places will say, "Peace be to our fathers, their examples will be hard to excell, their task was well and faithfully done."

\section{The Plant Breeder}

The plant breeder before making combination should with great care select the individual plant which seems best adapted for its purpose as by this course many years of experiment and much needless expense will be aroided. The difference in the individuals which the plant breeder has to work upon are sometimes extremely slight. The ordinary unpracticed personcannot by any possibility discover the exceedingly minute variations in form, size, color, fragrance, precisity and a thousand other characters which the practical 
breeder perceives by lightning like glance. The work is not easy, requiring an exceedingly keen perception of minute difierences. Great practice and extreme care entreating the organism operated upon and even with all the naturally recuired variation added to those secured by scientific crossing and numerous other means the careful accumulation of slight individual differences through many generations, is imperative after which several generations are often but not always not necessary to thoroughly fix the desired type for all practical purposes. 'The above applies to annual or those plants generally produced by seed. The breeder of plants which can be reproduced by division has great advantage for any valuable individual variation. Can be multiplied to any extent desired without the extreme care necessary in fixing linear breeding, the one which must be reproduced by seed, but even in breeding perenials the first deviation from the original form are of ten unappreciable to the perception but by accumulating the difterences through many generations the deviation from the original form is often astonishing, but by careful and intelligent breeding any peculiarity may be made permanent and valid. New species are at times produced by the art of the breeder and there is no known limit to the improvement of plants through the education of breeding and selection. How soon do the lowly native plants, fruit or grasses disappear from the face of the earth? When once the plant breeder has by his as it were magical touch brought forth the wonderfully improved fruit, fl,ur gains, etc. What great changes have been brought forth in our day: for example, the little nubbeny eight rowed squaw corn of New England, which we grew in our younger days compared with the Mammoth White and Tellow ears of today. The plant breeder is an explorer into the infinite, he will have no time to make money and his castle and brain must be clear and alert in throwing aside possible ideas and rapidly replacing them with living throhbing thoughts followed by action; then and not until then they shall create marvels of beauty and value in new expression of materialized force for everything of value must be proluced by application of the forces of nature which are always awaiting his demand. The rast possibilities of plant breeding can hardly be estimated. It would not be difficult for one man to breed a new life, wheat, barley, oats or rice which would produce one grain more to each head or a corn which should produce an extra kernel to each ear, a potato to each plant or an apple, plum, ordnge or nut to each tree. What would be the result in five staples only in the United States alone the inexhaustable force of nature would produce annually without eflort or cost five million two hundred thousand extra hushels of corn, fifteen million extra bushels of wheat, twenty millions extra bushels of oats, two millions extra bushels of barley, twenty-five millions extra bushels of potatoes? But these vast possibilities are not alone for one year or for our own time or race but are beneficient legacies for every man, woman or child who shall ever inhabit the earth and who can estimate the elevating and refining influence and moral value of fluurs with all their graceful forms and bewitching shades and comhinations of colors and exquisitely varied perfumes. Those silent influences are unconsciously felt even by those who do not appreciate them consciously and thus with better and still better fruits, nuts, grains and flours will the earth be transformed, man's thoughts be turned from the base destructive forces into the nobler productive ones which lift them to higher plains of action towards that happy day when man shall offer his brother man not bullets and bayonets but richer grain, better fruit and fair flowers and beauti- 
ful homes undoubtedly the great Creator placed all plants upon the earth in their primitive state, as it were, at the start, at the same time giving to man the ability by hard work and study to bring to our notice the grand work of perfection and how nobly is this task being carried out. We see it each day most notably in the great variety and beautiful colors of flowers the great variety and better quality of grain and vegetables science, sees better grains, nuts and vegetables, in all new forms, color and flavor with more nutrients and less waste and with every injurious and poisonous qualities eliminated and with power to resist sun, wind, rain, frost and destructive fungus and insect pests and fruit without stones, seeds or spines, better fibre, colfee, tea, spice, rubber, oil, paper and timber trees, starch, color, perfume, plants, every one of these and ten thousand more are within the reach of the ordinary skill in plant breeding. This is the work of the plant breeder. On you now rests one of the next world movements; the guidance of the Creative force are in your hands. Man is slowly learning that he too may guide the forces which through all the ages performing this beneficent work which he sees everywhere, above, beneath and around him in the vast teeming animal and plant life of the world. These lines were brought to our mind when wondering amongst the higher peaks of the Rocky mountains, and while standing on the original maturial from which this planet was made thousands of ages have rassed and still it remains unchanged. In it no fossils or any trace of passed organic life are ever found nor could any exist for the world's creative heat was too intense among those heights of rock, ice, cleft, glacier, cloud and water worn; we stand face to face with the first and last pages of world creation for now we see also tender and beautiful flowers adding grace and form of colur to the grizzly walls and far away down the slopes stand the giant trees, oldest of all living things, embracing all history but even their lives are but as a watch stick since the stars first shone on these barren rocks, before the evolutive forces had so gloriously transfigured the face of our planet home.

The ripe fruit is dropped at last without violence, but the lightning flashed and the storm raged, and strata was deposited and up torn and bent back and chaos moved from beneath to create and flavor the fruit and color the flower on your table today.

Some qualities nature carefully fixes, and transmits but some and those the finer exhales with the breath of the individual as too costly to perpetuate but I notice also that they may become fixed and permanent in any stalk by painting and repainting them on every individual until at last nature adopts themf and bakes them into her porcelain.

\section{Soil, Air And Plant}

\section{[BX PROF. F, B. MUNFORD]}

The roots of farm crops must be continually supplied with fresh supplies of air, or they will turn yellow, appear sickly and die. Seeds will not germinate in any position where they cannot receive the oxygen of the air. This explains why heavy, watersoaked soils are rich in plant food, but their saturated condition exiludes the air, and the roots cannot grow healthy. This supply of air must be continually renewed, and there must be, therefore, a kind of soil breathing to supply fresh air to plant roots.

One of the most important processes in soil is the change of organic mat- 
ter to available p'ant food. This process cannot go forward in the absence of air. The most important available elements of plant food in the soil are the nitrates, and these are formed only in the presence of soil air.

The air must penetrate to the extreme length of the root growth of plants. Th'rs, in the case of clover and alfalfa a ir must penetrate on certain soils from tive to twenty feet in depth. One chief result of growing clover on land is the deep holes made in the soil by the roots of the clover. When the roots decay these are left open for a time. The air thus penetrates easily to the roots of succeeding crops.

\section{SOIL VENTILATION}

In nature the air in the soil is daily renewed by changes in temperature, and hy winds sweeping over the surface. As the soil warms up during the day, the air expands, and a portion of it is forced out. As it cools down again at night, the soil air contracts, and new fresh air from the atmosphere flows in. Fvery rain which falls upon the surface carries with it air, and the percolation of this water downward forces the air from the deeper layers into the natural drainage outlets, and new air rushes in.

\section{INCREASING AIR IN SOILS}

Tillage of whatever kind is one method of supplying air to soils. Plowing, harrowing, cultivating with soil working tools are all efficient for this purpose. In wet, retentive soils, under-dainage is a very efficient method of bringing about soil ventilation.

The rotation of crops helps to aerate the soil. The deeply growing roots of clover, alfalfa and similar crops, leave air passages in the suil, and these become efficient channels for the introduction of the life-giving air.

SOIL, TEMPERATURE AND PLANT GROWTH. SOILS MIUST BE WARM

The importance of a certain degree of heat in the soils furgermination and for plant growth has already been considered, There are certain limits between which seeds will germinate and plants grow. Neither the maximum nor minimum temperature is most favorable. The soil may be too warm and it may be too cold. In the Temperature $Z$ one it may be said that with most of the spring crops the average temperature during the growing season is too cold to produce the largest crops. The processes which combine tc bring about plant growth are mechanical processes, processes of so'ution, and physical processes like osmosis all of which are carried on more efficiently and rapidly in warm temperature The lowest temperature at which growth starts in most crops is from 45 to 48 degrees fahrenheit, but the best results are not reached until the soil has ruached a temperature of nearly 70 degrees. The average soil temperatures in the northern half of the I'nited States are considerable colder than the ahove. At the Pennsylvania Experiment Station it was found that only during two months were temperature warm enough to proluce the best growth of farm crops. It is, therefore, true that the average temperature of soils is too cold. In some practical experiments with farm crops it was found that the germination of wheat, rye, oats and flax does forward most rapilly at 77 degrees to 87 degrees while corn and pumpkins germinate best at 12 to 101 derrees. Haberlandt found that corn would germinate in three days at (i.) degrees, but required eleven days to germinate when the temperature was only 51 degrees. At 65 degrees oats germinate in two days; but the same seeds required seven days to germinate when the tem- 
perature was 41 degrees. This explains why corn rots in the ground if corn planting is followed by cold wet weater. The question is, Can we influence favorably soil temperature by practical methods?

\section{CONDITIONS GOVERNING SOIL WARMTH}

The conditions which determine the degree of heat in soils are: (1) the amount of water in the soil: (2) the incline or slope of the soils: $13 ;$ the color of soils. The most important of these conditions is the amount of water. A soil that is saturated with moisture is a cold soil. It is cold hecau-e of the large amounts of water evaporating continually from the surfice. Th craporation of water is a coolingr process. We bathe our hands and foreheacl when heated, and the evaporation of this water from the surface of the budy results in cooling the system. A drop of ether or alcohol upon the hand leaves a cold sensation, due to rapid evaporation. The physicist tells us that it requires 960 heat units to evaporate one pound of water. This imount evaporated from a cubic foot of soil would lower its temperature more than 10 degrees.

King states that 100 units of heat will raise 100 pounds of water from :32 to 33 degrees. It requires only 19 of the same units to raise the $s, m$. weight of dry sand one degree of temperature. A dry soil then is a warm suil and a wet suil ever a cold one. iny method of cultivation which prevents i vapuration of moisture from the surface of the soil will increase the soil templerature and indirectly increase the yield of crops. The under drainage of wet soils results in increasing the warmth of the soils drained. ('ultivation of the surface, which destroys the capillary condition of the soll, and prevents rapid evaporation, warms the soil and thus promotes directly the better srowth of plants.

Soils which slope to the south are warmer than when sloping in any other direction, because they receive the direct rays of the sun. A black noil is always warmer than a light-colored soil, because black colors ahs irb the heat rays of the sun, and light colors reflect them. This interesting physiral fact can easily be demonstrated by placing a white handerchef a d a bla $\mathrm{k} c \mathrm{cith}$ of equal size on the snow on a bright sunshiny day. Thesn. wunde r the black cloth will melt away while under the white cloth it will remain uncha insd. In general it may be said that one of the most important eficits of woul cultivation of the soil which is always a factor in good farming in the warming of the soil.

Prof. F. B Mumford bears out in full all that we have said in regard to warning for the soil. I am anxious that each reader shall thoroughly read and think ' $n$ what he says. It is interesting reading and such as will do grood to those who follow the thoughts given.

\section{The Abandoned Farms}

We have all seen or read of the abandoned farms in the New England States, and other parts of our great country and such reports are stubhoril facts. And yet the writer, who was brought up in that section, well remembers when those same farms were the garden spots of our nation. T'l ' $y$ were. in fact, fertile, large producing lands, that grew a great abundance of grains, grasses and vegetables but their owners knew nothing of the methods uf preserving the fertility of his lands. He did not, in fact, dream that in each bushel of grain that he had so? $\mathrm{d}$ was selling just so much of the best of of his 
soil and that the day would come when his land could not respond from lack of humus which is the vegetable matter in the soil. Now to determine the quantity present on your farm you have only to dry the soil thoroughly then weigh a suitable quantity of the dried soil, place it in an iron vessel and set it over the fire, bring the contents to a low red heat and stir for a suitable length of time, say for twenty-five or thirty minutes; when cold weigh again; the difierence between the weight before and after heating is the humus that was in that amount of soil; this has been consumed by fire, but heat is not the only thing that destroys humus. Injudicious cropping will remove humus from the soil. As illustration, if commercial fertilizers, even of high grade, be employed for a sufficient number of consecutive years no means in the meantime being employed to make the necessary humus, the soil will become dead and compact having more the appearance of ashes, the humus has been extracted as eflectively as if done by heat. In this condition of tne suil no commercial fertilizer however good or large, will produce a profitable crop. The necessary quantity of humus must be restored to the soil, before there can be any more profitable farming. To maintain a supply of humus a heavy green crop should occasionally be turned under. When the vegetable matter rots it will supply the needed humus. In selecting plants for humus purposes preference is given to those of le : ume family for the reason that in addition to supplying humus a bountiful supply of nitrogen is drawn from the air. A good crop of clover or cow peas or of other legumes easily will mature $\$ 15$ worth of nitrogen per acre which, when turned under will serve the next crop. Iiye is nearly as good for humus purposes but the nitrogen, except which has been drawn from the soil, is wholly lacking, none having been drawn by this plant from the air. For the northern section of our country red clover, alfalfa, cow peas, eic., are the best but in the south the hirryvetch or crimson clover may be grown during the fall and winter aud cow peas soy beans, etc, during the summer. The rauker the growth of these plants the greater will be the quantity of nitrogen drawn from air. Hence it usually pays well to liberally fertilize said legume crops. Here is a good fertiliz'r for cow peas, red clover, etc., etc., which shou d be liberally used on light or thin soil $M x+001 b s$ of muriate of potash with 1000 lbs of acid phospedte and apply 400 to $6000 \mathrm{lbs}$ per acre, preferab y a few wetks before seeding. If cow peas are used they should be planted in three feet drills, fertilizer applied in the drills and the plant thoroughly cultivated from start tu finish. One peck of seed per acre will ba ample for forage or imp ovemeat purposes with proper cultivation the fertilizer will act far better th $\mathrm{u}$ when broadcasted without further cultivation. If the improvement of the land is the ohject sourht the entire crop at maturity should be turned uder. When the quantity of vegctable matter is large several months will $b=n$ ncessary for it to properly be composed before seeding thereon. In the meantime the soil should he plowed several times and tae rotted vegetable matter properly mixed therewith: the 1 and not until then will the soil bs in a proper condition toyield its strength Some prominent writers advocate feeding the hay and returning the mature to the land I f this plan be adopted twelve mus. may cuap,e before it is returned to the land and by reason of the manure $h$ iving been scattered here and there much of it will never be returned. The action of the vegetable matter on the soil is such that I am emphatic in turning under such portions of the green crop as can well be spared from the barn. 
pea hay contains about the same nutritive value pound for pound as wheat brand and can therefore be substituted for wheat brand The hay contains ten and eight-tenths per cent of protein and thirty-six and six-tenths per cent of carbohy ${ }^{3}$ rates. In a well balanced ration there should be one part of protein to five or seven parts carbohydrates. Timothy hay contains two and eight-tenths per cent of protein and forty and four-tenths of carbohydrates; hence if a a ton of timothy or some similar hay, corn fodder, shredded corn, etc, be mixed with a ton of pea vines, the mixture will contain one par of protein to nearly six parts carbohydrate. This is a fairly well balanced ration and will give far better results than the two hays will if fed separately: alfalfa, crimson clover, etc., may be submitted for pea vine hay. The farmer who wishes quick results may use propared fertilizer. It has taken many years to reduce fertility of our lands. It will take time to restore it hut so surely as the above systems are followed so surely will your farm be brought up to its natural standard. The laws of nature may not be broken except we must most assuredly pay the penalty. The man who reads and thinks will most assuredly learn the lesson, so that we may escape the hardships of our fathers and there will be no more abandoned farms.

\section{The Possibilities of Farm Education}

That the farmers of our great Agricultural country are fast waking up to the fact that they must be better prepared to meet the great competition that the introduction of quick and cheap transportation to all parts of the universe. The railroad and steamboat today make it possible and at the same time profitable to ship products thousands of miles and from many foreign nations where land is cheap and labor at such figures that our farmers could not sustain life with it, to say nothing of comfort and luxurieshence you will at once observe the great necessity of devising some methods by which our American farmers may be able to compete successfully with those conditions and at the same time sustain the beautiful homes and the dignity of the American Agricultural wor!d If so, their first thought must be a better education along the lines of Agriculture and the management of of their farms. The kin 1 and quality of grass, grain, fruits and vegetables, stock and other products. All must be of the best and to do this, knowledge must be had. If so, to whom must they look? Our government recognizes that the advantages of more and better knowledge have formed the Agricultural Bureau of the United States. The best minds to be found a re studying the latest methods and appiances to be found in all parts of the world, together with the best plants, truits, vegetables and seeds. Full reports are made to the government who in turn through th ir bulletins send it out to the people. This is a great and good work but in our vastness cannot reach but c smparatively few. Next in importance are the state Agricultural colleges and schools. They are nearer our homes and the penp'e. They have attracted to themselves our sons and daughters who have first got the spirit at home of the beauty and benefit of better understanding of the methods of practical farming. At those schools they may be brought to as nearly perfection as it may be possible but this does not reach the masses although it does create a thirst for more and better knowl, dge amongst i he great masses of farming people. The next and greatest educator of all that meets fully the requirements necessary and scattered broadcast each week at a rery 
nominal price are the Agricultural papers which are being delivered each week to those that they most assist. A farm paper from, as it were, a farmer to his brother farmer. No new methods, appliances, fruits, llowers, seerls or plants, tnat may be brought to notice escape their observation and criticism along this line.

No state has so many bright minds and forceful writers as Iowa. For many years it has been our pleasure to read such papers as The Furmers Trils

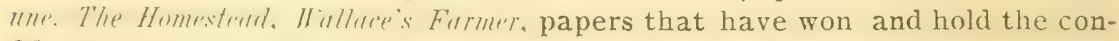
fidence of the thinking and up-tc-date farmers of our land Other states are fast following their example. A mighty giant altbough but a few years old the Tuentirfl" ("ntur!" Firmpr of Nebrashra has taken its place at the head in that state and is surely rolling along the noble work and we trust that the time is not very distant when the good people will demand that arriculture shall be taught in our public schools: that there shall, at least, be a training farm in a small way where the Jittle ones shall be taught the first rucliments of plant and llower growing and a thirst developed amongst our children for nature's purity and beauty instead of yellow covered literature, cigarettes and fiction. When that time shall have arrived the city student will compete with his country cousin for the substantial homes of farm life and prosperity that only comes from higher knowledge of nature in all its beauty.

Why cannot we as farmer's family read, observe and learn the new and improved things as they come along aud keep on a level with the city family? We inust read more, observe more and put into practice what education and arlvantages we have, and do our best to keep abreast with the times. Then we can feel ourselves just as intelligent, just as polished and just as much admired as our city cousins, and neel not harbor the feeling that we are being laughed at or snubbed because we toil in God's subiime instead of the dark, glo my city oflice or store and when someone refers to us as "farmer" we will feel as much pride in the name as others do to hear "banker," "merchant," "lawyer," etc.

\section{The Twentieth Century Farmer Seen by the Eyes of an lowa Citizen}

The twentieth century farmer is the best specimen of a well developed, all round man the world has ever seen. He holds a unique position of power and responsibility among men.

He is the sheet anchor that keeps the nation from drifting upon the shoals of political experiments. the ballast that holds the ship of state steady through a political storm every four years. He is the nation's time lock that prevents the nation's wealth from all being squindered in senseless speculation. He is the fountain of life that sends a new stream of new life blood into the dissipated and exhausted cities, preventing mental collapse and moral degration. He is the steward that guards well the bread-box of the world, keeping monopol sts from controlling the necessities of life.

No man is su at the mercy of commercial life, yet no man can be so independent of commercial life as the intelligent farmer. When he kuys the farmer pays the other man's price-when he sells the other man sets the price on what he sells. But offsetting this apparent condition of slavery stands the fact that the farmer raises what he needs to cat and feed, and he does not liare to buy much from anyone if prices are not right, and if he is out of deht he can get along without selling until the price is right. 
So we find this man the most independent man on earth if heowns a small farm free from debt.

The world's rulers, be they called this or that, are slaves to an exacting public. They must serve the people that they rule over; they must serve custom, fasbion and folishness. If one sneezes, the world knows in a few minutes that he has caught cold, how he caught it, who attends him, how his temperature and pulse is, what his prospects of recovery are and who will be the ruler if he sneezes again.

Assassins track the rulers as the hunting log tracks the fox. Covetous politicians seek their downfall. Cartoonists insult and degrade them daily. Verily, rulership is slavery, not freedom.

The merchant is successful in proportion to the way that he pleases his customers. He must he pleasant whether he feels like it or not. He must flatter the women and kiss the babies, or they go elsewhere.

So it is with every line of business. Men must bow and scrape, flatter and applaud, throw out bait to catch trade and work till they sweat blood to hold their trade. The world is fickle. No m un can say he does not care what people think of him or his groods. No man can say, "I don't care for you."

Every business, every trade, is at the mercy of a tyrant called unions. No man may think he can do as he please as long as these exist. The independent working man is dependent. He finds that life, liberty and the pursuit of happiness is but a Fourth of July dream.

An effort has been made time and again to organize the farmers into a union or trust. Thank God, it nas never succeeded. Let us have one avocation that is free from tyranny within our own ranks. Let us be free to sell when and where we please.

The twentieth century farmer, owner of a small farm that is free from debt, stand-distinctly as the most indept ndent man on earth. When hired help organize against him he can pasture his farm and do witbout help till men come around and a,k for a job. When railroads and grain dealers conspire against him he can quit raising grain to sell until corporation come to their senses. When strikesstop the wheels of commerce hecan sit in the shade and wait for the return of common sense and brothərly luve.

The twentieth century farmer is the best fed man on earth. Think not? Ask the parson who eats at the table of city and country people. In town he goes for a call about dinner time and is spi. $d$ hy the little girl, "Nama, the preacher is coming." Nama must get up a fine dinner and "phones to the market for a chicken-the preachers always like chicken. Soon the delivery hoy brings the chicken. It is a lead one, been dead a long time. It has hung in the shop to "cure" until it is blue and callaverous looking, too skinny to make a decent grary. l'oor parson, their troubles are many. "Won't you have some more strawberries?" They are so nice." Berries: they were what the farmer did not want, were jolted in a wagon till more or less mashed, set in the sum in front of a store, gathered enough dust to make them gritty, set. in the ice box till chilled, picked over and served with skimmed milk. "No, thank you; berries do not agree with me.',

The reverend goes driving into the country, is spied by a gond farmer's wife, wro calls him in to stay for dinner. Never refuses Soon a nice, plump, yellow-legged chicken is shot and in the pot. Grary? I guessyes. And big, lucious strawherries that were just picked from the garden. No little sauce 
dish, but a big saucer full, heaped up like a cushion pyramid. Cap it with sugar and baptize it with cream, realcream, and see if the parson will refuse a second dish.

This is no dream. This is real life in the homes of all progressive farmers today. They have a variety of garden stuti, always fresh, always ready, with all kinds of meats and fruits at command, that would bankrupt a city banker if he were to buy them for his table. Eat from the hands of a $\$ 150$ chef if you will, but give the bill of fare gotten up by the farmer's wife for themselves.

The twentieth century farmer is the most broadly and practically educated man on earth.

Book learning is not education. Fducation is a combination of common sense and practical experience. Common sense is not learned from books, nor can experience be so obtained. Books have their place. They serve as references for a while and as ancient history in a year or so after they are published. Experience is ever changing.

The farmer lives a life of constantly changing experience. He is a student of things as well as of books. He learns to see, hear, feel and do. He studies the book of nature with the Creator as his master--a master who constantly turns news pages and furces the student intu new condition, severely punishing ignorance and liberally rewarding the faithful learner.

No man has to change work so constantly and study such a variety of subjects as does the present day farmer.

The trend of education is towards specialization. The workman learns but one thing, the professional man makes a speciality of one branch of his profession. Competition narrows education.

The farmer is independent because he is sort of Jack-of-all-trades and a fair master of all. He can lay brick or stone, plaster, paint, do carpentering, blacksmithing, surve ying; he is a machinist, engineer, road boss and school director. He must know somewhat of the sciences, of business, law, medicine and even theology. He has something to do with ornithology, entomology, horticulture, floriculture and landscape architecture. Study the curriculum of an agriculture college and you will see what the young farmer of today has to know before he even begins to farm for himself.

The farmer trains his eyes to see, his ears to hear, his taste to differentiate, his nose to judge, his hands to feel, his feet to keep under him, his heart or sound to sympathize, his brain to tbink, his judgment to act, his conscience to discern.

He works with both hands, both feet, head and heart. Surely our twentieth century farmer is a well developed man. None with him will compare.

Let us compare the independent farmer with other callings. Lest some farmer should be contemplating sending his boys t' the city to learn a profession and thus become "respectable," I want to rem nd him that farming is not what the carto mist pleases to 1 " cture it in conp 2 rison with ocher business.

Would you have him study law? Law is honorable and respectable when practiced by a respectable man-so is any business. But the law does not offer opportunities for independent thinking asd judgment. The judge looks wise and is so considered, but his pusicion de pends upun bis adherance to past decisioas. The attorney presents his ca-e based upon precedent and not upon any new thought he may have or any new theory he may present. He 
quotes authority like an encyclopedia but he never stands as an autbority on anything himself. He calls the expert witness-a farmer perhaps-to be authority.

The law is a good stepping stone to political position, but every step from the farm and the White House is a step toward dependence and away from independence.

Going to try medicine? Noble work, useful profession. But it is narrow and very binding. The conscientious physician must be on duty day and night. He has little or no time for broad research or personal pleasure.

Make him a minister! The ministers has opportunities for a broad experience. He is listened to patiently for what he represents more than for what he is as a man. He is a man without a permanent home. His life is one of constraint and not of freedom. His truubles are many-his pleasures few.

Compare the life of a prosperous farmer with that of any other and it is easily seen that it is safe to gro slow when pushing the boys out into the world to win happiness, fortune and honor.

Do not think I adrocate keeping the boys on the farm. Those who do not fit into farm life should get out of it. All I am trying to do is to change the minds of those parents who think farming is beneath their son and who dream of city life as one of ease and prosperity.-Twentieth Century Farmer.

\section{The Farmer With Brains and Thought}

Our readers will remember that we have heretofore referred to the fifteen-acre farm owned by J. D. Detrich of Flowertown, Pennsylvania. Twenty years ago Mr. Ditrich purchased this small farm, which was not considered in his neighborhond as a piece of land which would contribute much to a man's income. This Mr. Detrich also found out af'er the first year's operations had been concluded. as he had a harl time to make the first payment on the mortgage, to meet tbe interest paympts and to pay for the labor employed. The reason for 1 his Mr Detrich says was due to the fact that during the first year he ran the farm according to the old methods of farming generally in use. A goodly portion of the farm wis in grass, but the whole fifteen acres could not support more than two cows and a horse, as the land was run out and apparently depleted of its fertility. At the end of the first year, it was decided that something had to be done, either the farm had to be disposed of, or else more improved methods of farming had to be employed. Mr. Detrich chose the latter. Being a well educated man, he turned his attention to books that gave information on arricultural matters. He studied the experiments carried on by the experiment station, read a large number of agricultural papers, and put into practice what be learned from them. After reading some Mr. Detrich came across a book on soiling and finally decided that pasturing land under his condi ions was not a paying proposition, but that he must raise soiling crops, and produce more feed per acre, so as to support more cattle on his snall farm He never bought a dollar's worth of commercial fertilizers nor did he purchase any barnyard manure, but relied upon what was made on his own farm. The farm gradually increased in fertility until now it produces enough roughage in the way of green feed, silage and hay to support thirty head of cattle the jear around, or in other words, it feeds two head of cattle per acre and last year one and one-half tons of hay were even sold off from the place. 
In regard to his farming, Mr. Detrich recently said before the Pennsylvania Board of Agriculture:

"The plan of soiling the dairy cattle was adopted over against the extravagant method of pasture. It was conducted carefully and obserringly but not with the good results that wire claimed for it. The production of milk from cows grown and fed in the stall was not equal to the same animal's yield when on pasture. Bit the saving of manure by the soiling sys:em was a marked advantage. Someone has said that no one owns deeper than he plows, and the eighteen years experience in soiling sugrest that no one plows wider than the land is manured.

"It was about this time that the balanced ration of Wolf was being discussed in the journals and agricultural magazines and gave the writer a great deal of information that was entirely new on the feeding of a diary animal for protit. The adopting of the balanced ration by Wolf, as a guid, and not as an absolutely me hanical rule, made the soiling s;stem a real succoss.

"To carry on the soiling system many changes were iatroduced into the clairy barn for the comfort of the dairy animals. Cement lluors, additional windows, ventilators, platform stalls, well-made water-tight rutters, with cement bottoms, so as to retain all the manure po sible, bcdding cut onequarter inch, water introduced direct into the dairy harn, comvenient fecd spouts and all green and dry forage run through a cutter and droplud down into the feeding passageway.

"Convenience and cleanliness are watchwords of the dairyman. Clean cattle, clean milkers, clean dairy barn and clean vessels stand for clian milk. For no strainer will strain dirt out of milk. The coiling of the dairy animal means cleanliness. She must be curried for the sake of health as well as cleanliness. And strict attention u $u-t$ be given to all sanitary regulations in caring for milk according to our modern civilization.

"After all these years of experience in suiling, nothing would induce a return of the ola system of rota ion and pasture. By soiling the acreage of the fifteen-acre farm is increased at least four times. The product of the dairy is coveted, because there is never any flavor of grass, weeds, garlic or any foreign taint imparted to the product of the dairy.

"The cows have a longer period of lactation, largely accounted for on account of a regular supply of water, food and attentiun. There are now in vogue two systems of soiling. The one is the growing of the green crops in the tield and baving them come in succession, so t at there is an abundance of green food at least for seven months in the year in the climate around Philadelphia. The other, and the one m st likeıy to be adopt $d$, and which is a real boon to the large farms as $w .11$ as the small ones, for it is entirely practic $s$ for both, is the soiling of the green crops for summer as well as winter use. The silo has been the indippensable fuctor on th: fifteen-acre farm since 18\%: An abandoned chicken house on the iittle farm was converted into a primitive silo to store the succulent food of summer for the Jerseys. It was a venture to risk mo. ey, time and machinery twenty years ago. Today the earnest inquiry i-, how can I get one? There are now two 60 -tons silos on the same little farm.

"The advantages in soiling are so numerous in the experience of the writer that he has concluded that no man but a rich man can atford to pasture a cow. 
"Pasture is wastefui; soiling economic. Pasture is like killing an ox for his liver; soiling is the saving and using of the entire animal.

"Th: animal in pasture has one mouth to eat ana four feet to tramp. In dry weather the grass is pulled out by the root; in wet weather is tramped into mud. This farm last year wintered sixteen cows in milk, one Jersey bull 4 yearsold. four heifers 2 years old and ten head of young stock ranging from 1, montbs down to three weeks, and two horses. All hay, beduing and silage were last year grown on the fifteen acres, and none purchased at all in the market. We attribute this wondrous yield to the soiling system. It lifted the mortgage, paid the taxes and labor and finds its owner not complaining that farming doesn't pay."

The above is a good example of what may be done by intensive methods of farming. It should be understood that Mr. Detrich did not do any gardening beyond uhat was needed for his own family, but he kept good dairy cows to convert the raw waterial of the farm into money and manure. While his plan may not be adapted to our western conditions, yet it is a fact that in many instances we are depending entirely too much upon pasture and are not paying enough attention to the production of soiling crops. Especially is this true with reference to the silo. Every man who milkes ten cows or more should by all.means own a silo and store away a large amount of green feed for winter use. The time has come when we must get more out of the land per acre than we have been getting in years gone by and the silo is a structure that will help solve this problem.

The ['aited States government has recently reorganized the great value of Mr. Tetrich's farm and has purchased the same at a cost of $\$ 1000$ per acre.

The farm will be used as an object lesson of what can be done by intensive farming meth.ds. Silentific soil and other experiments will also be conducted on the farm. Mr. Detrich has now gone to manage a 340 acre farm in Chester county, Pa., which will from now on be conducted on the same plan on which h sorn at Flowertown has been conducted for the past twenty years.-Farmers Tribune.

\section{Agriculture at the Head}

There is no need in wasting words to show that the agriculture of this country should be developed extensively and rapidly. The whole country and its people in every profession are experiencing a development such as has never been known or even dreamed of before in any period of human history since time began.

The prosperity of other industries and all of the people aftords an opportunity for this derelopment of our agriculture, we as farmers can protit by it, and what is of more consequence the country as a whole needs it.

The population of our country is doubling very fast, emigration from foreign countries where never so large and all our customers and the demand from fureign countries are fast doubling up for all products and today in the corn growing part of our U. S. nearly every acre that can be successfully grown to corn is under cultivation. There are developing many new uses to wh.ch it is being applied, a great expansion in the uses to which it is adapted and the only way that we can supply these demands will be to improve the seed and manner of cultiration, the methods of sustaining the fertility of the soil in such a manner that we may grow doubly and threbly the amounts we formerly did under the methods of the past. Go back twenty 
years. C'orn was but corn, of course it was a little better than the same was fifty years ago. Though the improvements have been made by selection, without any thought of what the bearing would be in the future, but when the time did arrive and when man did begin to think and talk and when the fact was thoroughly demonstrated that great improvements were possible then came the awakening and tchay through the influence of thinking farmer, through the agency of the agricultural press the great work is groing on, all realizing the fact that we must grow larger yields of better product and at less expense.

We need to raise larger yields. We know enough already to believe that with better bred varieties and with hetter methods the same expense we now bestow upon an acre should bring us better yields and at no higher cost. As to the world that is to consume it, I never knew it to be too well fed, for the sun has never shone upon the earth a single day without shining upon starving people. We talk of our greatness, and we are inclined to ignore agriculture as an nccupation fit only for the inferior people, and to tbink that the business of food production will somehow take care of itself. But the stubborn fact is that mankind as a whole has never yet learned how to get enough to eat.

Here we come in contact with one of the great vital problems of our success. One of the imperitive laws of nature. We must heed it. Today we are hearing much said in regard to the eastern states. It is said that mucb of those sections have been so run down they cannot be made to grow enough to support the wants of the most simple people, yet many of us fully remember when that portion of our $[$. S. was the great producing and feeding portion of our nation. Why is this? In our judement but one thing was thought of at that time. The cultivation was simple, the only object being, to get all that were possible today, no heed being given of tomorrow. The land was robbed and nature outraged, the books were closed until such usages as would pay the old score and put some capital in the bank when business will be resumed and good interest paid. These lessons are imperitive and must be learned.

Those who have possessed themselves of rood land and have made the most of it have in some way prospered and have gradually possessed themselves of a large share of the earth aud the fullness thereof, laying all others tribute to their energy, ability and foresight. This is now the opportunity of this country, and therefore we should make our lands produce to the utmost.

With new and improved seeds of all kinds our thinking toilers all along the line, our great government expending many thousands of dollars in the search in all parts of the world for seeds plants grasses, fruits, etc., that may be adapted to our vast and varied climate and soil and while of course some selections brought forth will be worthless the better will be obtained. Our farmers are today the ones at the head. They are blazing the way to prosperity with better varieties and their adaptibility while the manufacture of implements are filling every want bringing out the implements that seemingly have the mind of the builder. All seemingly having caught the spirit of progress and are proudiy marching on to capture the world.

Again, if we are to get the most out of our lands we must learn to produce the highest quality. There is more money in it to the farmer and more sat- 
isfaction to the buyer. For oblivious reasons there is generally an abundance of the ordinary, but American agriculture is not to be satistied until it produces food of the highest grade for the markets of the world. Nowhere else on earth is the land occupied by a people so intelligent, so educated, and therefore so able as ours, and if we live up to our opportunities we shall never rest satisfied until we are not only the best fed people on earth, as we are today, but until we have attained commercial supremacy in the agricultural markets of the world. It is quality with lessoned cost of production that will do this, and we are, therefore, in the markets for new ideas and better methods in agriculture.

Did it ever occur to you that the old Indian corn of our grandfathers' day with the people who cultivated it have passed from the earth torever, and that part of the world lacking in the art of up to day agriculture are only half fed. are far behind in intellect, morals, and religion and it has often occurred to me that in sending our missionaries to foreign lands to teach, as it is often said, the heathen, the great reguirements ought to be the ability of teaching agriculture and all of its improvements.

\section{Must Maintain Soil Fertility.}

Nor is this all of our problem. We must not only raise larger yields of higher quality and produce them cheaper, but we must learn to do it without running down the fertility of our lands. If we cannot do this then our success and our greatness are but temporary, for we are selling out, giving away or wasting the very possibilities of the next generations unless we preserve unimpaired the fertility of our lands.

Our children and our children's children will need good fool, and an abundance of it. They will have their troubles to meet and their supremacy to maintain as well as we, and altogether likely it will be under conditions more complex than ours, certainly not simpler.

Here are deep and far reaching questions of public policy regarding the treatment of our lands, which in the last analysis are of public and not private concern. These are matters which, if well looked after, will make our future as well as our present greatness and happiness possible, but which, if neglected or wrongly administered, will make them impossible, no matter what the form of government, no matter what the social or the religious standard may be.

Nothing can be clearer than this, that if the agriculture of this country is to keep pace with other internal development and if it is to accomplish most for itself and for the country now and for all time, then it must take on and sustain a pronounced developement; and the problems and the details of this developement must be the special charge and care of the agricultural people themselves.

It is not that men of other callings or professions would by design either arrest or impede the developement of American agriculture All men of even average intelligence see its importance and would have it developeai: besides they are primarily interested in other things, just as we who are farmers believe in the necessity of great and prosperous manufacturing plants or lines of transportation, and yet if their prosperity depended upon our exertions, our active influence, our opinions, our judgements and our advice, I fear their prosperity would appreciably suffer, if not come to an end altogether. 
It is now and always will be a fact that agricultural people themselves must look after all matters touching agriculture. They know the details involved; It is the means whereby they live and by which the little ones are fed and fitted for life; it is life and love and opportunity and everything to them. They may be prejudiced but their prejudice will get rubbed away: they may be often wrong, but their judgements will be corrected; they may not be equal to the task, but they will come up to it. Right or wrong, equal or un qual to the task but they as we may be, it is both the privilege and the duty of the farmers themselves to study the possibilities and needs of agriculture and to work in season and out of season for its most perfect development. We owe it to our profession; we owe it to our country; we owe it to our children and to our our land to accept this responsibility and do this thing.

If, then this is to be our work, how shall it proceed? How shall the details be worked out? And who shall take the lead and blaze the road and be the special champion of the cause?

Each division of our great nation must be educated along the line in which they are to work or to which they are best adapted. The workman must be earnest, honest and intelligent. In this way we may pass down to our children in better condition than we took them, not only improvements in all lines and all directions. It cannot be denied that the nearer we work to nature and perfection the more we appreciate the great ruling power.

\section{How Legumes Improve the Soil}

In one of the year books of the department of agriculture, Washington, considerable space is given to a discussion of leguminous crops. It is pointed out that modern agricultural chemists have discovered that leguminous crops are not only consumers of available plant foods, but they actually manufacture the $m$ wt valuable and most essential nitrogenous compounds using the free gaseous nitrogent of the air. The transformation of an inert gas takes place throu: h the agency of minute almost infinitesimal bacteria which live within the tissues of the roots of plants of this order, producing knot-like swellings or galls upon them. Wach variety of legume has its own peculiar bacterium, comes in contact with and infests the roots: the plant cannot get m sre nitrogen than could he secured by the roots of a grass or tohacco plant. It can then only take up such nitrogen as is already present in the soil in available or suluble form. If these bacteria are entirely absent from the soil, the c over or bean will not fully develop unless an abundance of soluble nitrates are present.

This wonderful dependence of plants of the clover family upon the minute hacteria which live within the root tissues offers an explanation of the failure of su: i crops when tried upon soils not previously devoted to their cultivation. [t has been found by experiment in this country and abroad that such new lesumino's crops may be successfully cultivated by inoculating the land either witu ar ifi ial preparations or culture, containing these germs or with soil from a fi a'd where this crop has been previously grown. Good results are also som times secured by treating the seeds preliminary to sowing, by such an inocuation the yield of total dry matter has been increased sometimes from ten fold to thirty fold. Moreover it is found that there are no gall tubarcles furmed on the roots of leguminous crops when these nitrogen bac- 
teria are not present in a soil and hence there can then be no utilization of gaseous atmospheric nitrogen by them.

Nitrogen is the most important plant food; it is the most extensive fertilizer when purchased in artificial mature. It is also the most necessary element of animal food. For when it is entirely absent or present in insufilient quantities, there can be neither growth nor complete repair of worn out tissues, hence it can readily be understood why the abundant cultivation of leguminous crops is so necessary. The leguminous crops are the only crops which will, when plowed under, increase the total fertilizing materials of the soils. The farmer who thoroughly studies the above gets each point firmly fixed in his mind, and carries out the principles as near as possible will most assuredly reach a rich reward.

\section{Bacteria And the Nitrogen Problem}

[BY GEORGE T. MOORE]

Physiologist in Char!le of Laborator!l of Plant Physiology. Bureen of Plant Industry.

INTRODUCTION

There is probably no fact in plant physiology which has been more firmly established than all plants must have nitrogen in order to thrive, and that under normal conditions this nitrogen must be obtained through the roots in some highly organized form. It is not necessary to discuss this point, for practical experience demonstrates its truth every time a soil is exhausted by any crop, and the farmer testifies to his belief in this fact when he tries to reestablish the fertility of his ground by adding some fertilizer rich in nitrogeneous matter. While there are certain other substances, such as the phosphoric acid, potash, iron, etc., which plants must have and can only obtain through the soil, the demand for nitrogen is so much greater and in one sense so much more important, that the question of the availahle nitrogen supply in the world has come to be looked upon as lying at the very foundation of agriculture and demanding the most careful consideration. Since the conditions of life in the civilized quarters of the globe are such as to cause a constant loss of nitrogen, there have been some who have predicted what bas been termed a "nitrogen famine," which is to occur within the next forty or fifty years, and the possibility of such a catastrophe has been very graphically portrayed. On the other hand, there are investigators who feel that the possibility of such a condition has been much exaggerated and that the amount of nitrogen in the soil can never be exhausted to such an extent as to affect the crop-producing power of the earth. In order that we may be able to form a more definite opinion upon the subject, it may be well to look at some of the ways in which nitrogen is lost, and then see how it may he reclaimed.

\section{HOW NITROGEN IS LOST}

In the first place, the conditions of life on the ordinary farm are such as to cause the constant loss of this valuabie element through the removal of the crops taken from the soil. If every crop that grew on the land could be returned to it, nature has made provision for getting it back in suitable form for plant food. In the case of nitrogen, neither plants nor animals are able to produce this substance directly in an available form. It is necessary that certain bacteria take hold of plant and animal products, and by means of pe- 
culiar changes produce nitrates from fats, sugars, starches, etc. Without these hacteria everything would have to come to a standstill long ago, for unless iecay takes place and the decomposed elements are rearranged into definite nitrogenous salts no plant is able to use them. Thus, it will be seen that certain bacteria in the soil play as important a part in the food supply of the earth as cio the animals and larger plants upon which we think we are so dependent.

It is hardly necessary to refer to the vast waste of nitrogenous material that is involved in modern sewage methods.. Millions of dollars' worth of nitrogen which would naturally return to the soil under action of nitrifying bacteria is every year carried off in various waterways and ultimately reaches the ocean, where, of course, it is of no benefit to man. More than fifty years ago Liebig said on the subject:

Nothing will more certainly consummate the ruin of England than the scarcity of fertilizers. It means the scarcity of food. It is impossible that such a sinful violation of the divine laws of nature should forever remain unpunished, and the time will probably come for England, sooner than any other country, when with all of her wealth in gold, iron, and coal she will be unable to buy the one-thousandth part of food which she has during hundred of years thrown recklessly away.

A third great source of nitrogen loss is through the action of a group of bacteria which have the power of breaking down nitrates, depriving them of oxygen, and reducing them to ammonia or nitrogen gas, when they are, of course, unavailable for plant food. This process of denitrification, while very useful in the septic tank, which is the most sanitary method of sewage disposal, is the source of considerable loss to the farmer, and manures may often be rendered practically worthless by the action of these bacteria.

Other means by which nitrogen is lost so far as plant foods are concerned, are the washing out of nitrogen salts from the soil and the burning of explosives which are largely composed of some nitric salt that would be directly valuable to the regetable kingrom. The action of nitrate of soda, or saltpeter, has heen studied experimentaily, and it is known that up to a certain maximum about 23 pounds of nitrate of soda will yield to an increase of one bu. of wheat per acre. Thus, when bundred of thousands of tons of explosives are used in waging war, every battle liberating nitrogen which, if applied to the soil, would increase the yield of wheat by thousands of bushels, the actual cost of war shousd be estimated at considerably more than is usually calculated: and if there is soon to be a nitrogen famine, war becomes more serious than ever before.

With all these destructive forces at work and nitrogen being liberated on every hand, it is no wonder that thinking men have become alarmed at the prospect, and have endeavored in every way possible to discover some means of increasing the world's supply of this necessary element.

\section{HOW NITROGEN IS GAINED}

The most valuable compound containing suflicient fixed nitrogen to be used in any quantity as a nitrogenous fertilizer is the nitrate of soda, already referred to as the basis of so many explosives. This salt occurs naturaily in certain regions of Chile and Peru, where for countless centuries the continuous fixation of atmospheric nitrogen has been carried on by bacteria. Un. fortunately, however, like any other mineral supply in the earth, the quantity is limited, and although it is diticult to get accurate estimates of the 
amount of nitrate remaining in the beds, authorities seem to agree that at the present rate of export the raw material will all be exhausted within from forty to fifty years. To show how much more rapidly this supply is being exhausted than it was possible forty years ago, it is only necessary to state that in 1860 all estimates showed that the amount of nitrate of soda then known would last for nearly fifteen hundred years. The demand has rapidly increased, however, and although the output is controlled, there is annually consumed in the world's markets nearly one and a half million tons of nitrate of soda, representing a value of about $\$ 10(1,000,000$. () f this amount the United States requires about 15 per cent, and it is by far the most expensive fertilizer that is in use by the farmer.

In addition to the nitrate of soda beds there have also been large deposits of guano, which have served as one of the principal sources of nitrogen. The greater part of the guano beds are now completely exhausted, however, and although new deposits are occasionally discovered, they are of such limited area, or of such a low percentage of nitrogen, as to have practically no effect upon the avilable nitrate supply.

There are certain other chemical salts which furnished a limited amount of nitrogen, such as the product which remains from the distillation of coal in the process of gas making, but all of them are obtained in such comparatively small quantities that they are not worth taking into consideration when one realizes the enormous amount of nitrogenous fertilizer necessary to replace the combined nitrogen which is annually removed from the soil in one way or another.

Ever since the importance of increasing the combined nitrogen supply has been realized, men of science have naturally turned to the atmosphere as being the most promising field for experiment and the one most likely to eveatually solve the whole problem. When it is remembered that nearly eight-tenths of the air about us is nitrog $n$, and that plants are ahle to obtain their entire source of carbon from a gas, which is present in the comparatively small proportion of one-tenth of one per cent, it seems almost increditable that there should be any more difficulty about a plant's nitrogenous food than about its supply of carbon dioxid. Since it seemed so well settled, however, that plants coull not use nitrogen as a gas, the chemists and physicists have made every effort to devise some mechanical means of making this element arailable in a combined form. It has heen known that discharges of lightning passing through the air are able to fix free nitrogen, and, beginniag with this as a basis, smme very satisfactory results have been obtained by the use of electricity. With a power sulliciently cneap and with perfect machinery, there seems good reason to believe that in the near future it will be possible to place upon the market a manufantured nitrate of sola or nitrate of potash that will be superior quality to the deposits found in South America. and that will also be reasonable enough in price to compete with the natural product.

\section{NITROGEN-FIXING BACTERIA}

Fortunately, there are still other means by which nitrogen gas may be made available for plant food, and that, too, without requiring the introduction of a commercial product, which must always be rather expensive, whatever degree of perfection may be reached in the mechanical operation of the process. Ever since the earliest days of agricultural science it has been 
noticed that certain land, if allowed to stand fallow for a considerable length of time, would gain in nitrates without any visible addition having been made. It is now known that one of the principal means of this iccrease in nitrogen content is due to a few forms of soil bacteria which have the power of fixing the free nitrosen from the air and rendering it availab'e for plant food. These organisms have been isolated and cultivated artificially, and great hopes were held at one time that it would be possible to inoculate land with these cultures and thus bring about a larye increase in the nitrogenous salts without the aid of any mauure or mineral fertilizer. Under certain conditions these hacteria seemed able to lo a larse amount of work, and there are experiments on record where the crops raised from plots incculated with nitrogen-fixing organisms were much greater than crops from uninoculated land. Infortunately, these results were not always constant, and such a large percentagre of failures had to be reported that from a practical standpoint the use of such cultures is now considered worthless. A matter of such vast importance to agriculture, however, should not be neglected simply because of first failures. It is quite possible that as we become better acquainted with the habits of these bacteria and learn the conditions which are most favorable to fixing nitrogen and the causes which prevent this operation from going on at all times, we shall be able to discorer some means of using these nitrogen gatherers in practical farming.

\section{ROOT TUBERCLE BACTERIA}

In the meantime there is still one other means at hand which can be used and has heen used for countless centuries as a most efficient method of conserving the world's nitrogen supply. Kver since the time of Pliny and other early writers upon agricultural topics, it has been known that certain leguminous crops, such as clover, beans, peas, etc., did not require the same amount of fertilizer as other plants, and indeed it seemed as though they actually benefited the soil instead of being a detriment. Various theories have been adranced to account for this effect, perhaps the most widespread opinion being that members of this family, owing to the unusual length and strength of their root yystem, were able tu draw upon a store of food that was not available to wheat and corn and other crups not belonging to the p.d-bearing group It is only within a comparatively recent time that the real cause of the beneficial ellect of these lerrumes has heen fully understood, and it seems that here again the bacteria are responsible for the nitrogen-gathering power: for it in because these plants are ahle to fix and use the free nitrogen of the air that fhey are of such benefit in rotation and in reviving poor and exhausted land. The immense yield of wheat following alfalfa or clover are easily understood when it is realized that there has actually been added to the soil a certain definite amount of nitrogen in such form that the wheat can be henefited by it. Such efficient users of the atmospheric nitrogen are clover and peas and similar crops that they can actually live and thrive in a soil that has not the first trace of combined nitrogen within it. If quartz sand he irnited to red heat, thus burning out all the nitrates, and then be plantel with peas or heans, it is posible to hring these plants to full maturity without in any way allowing a particle of fixed nitrogen to find its way into the soil. ()n the other hand. wheat or potatoes, or crops not legumes, will dic as soon as the small amount of nitrogen available from the seed is 
exhausted. What is the reason for this? It cannot be mert ly a difference in the length or extent of the root system, hecause plants.flourish where it is certain there are no available nitrates whatever. For a lons time the presence of certain peculiar nodules or tubercles upon the l.rum.s has been noted and speculated upon. These formations are always pre-ent upon the roots of leguminous plants grown under proper conditions, and may vary in size from that of the smallest pin head, in some clovers, to a cluster as iarge as a potato. They bave been thought to be due to the hites of worms and insects, or to be caused by conditions of the soil and various abnormal climatic effects, and only within very recent years has it been learned that these formations are due to the presence of the innumerable bacteria, ard that unless these tubercle-producing bacteria exist the plant is no more able to use the nitrogen from the air than wheat or any of the other crops which clo not have such nodules on their roots.

\section{MICROSCOPIC APPEARANCE OF TUBERCLES}

If a thin cross section of one of these tubercles be; examined under the microscope it will be seen that the cells are very much larger than in a normal root, and that almost the entire contents have been replaced by masses ot minute hacteria. These hacteria gain an entrance into the plant through the root hairs, and may assume shapes very different from the ordinary rods and spheres that are usually found in this group. The appearance of branching has led some observers to cousider that these tubercle?formers were not true bacteria, but belonged to some group intermediate hetween the bacteria and fungi. This is not prolable, however, for there is abundant eviclence to prove their relationship to the true bacteria, and while the p culiar shapes are somewhat characteristic of the group, they are not exclusively of this form, many tubercles having nothing but the short rods.

Just where the nitrogen is fixed and how it is used hy the plant have heen debated questions. Some have supposed that the presence of the hacturia in the roots simply acted as a stimulus, and that the leaves of the pl tut were thus able to take in nitrogen as a gas and to elahorate nitrates from it in some such way as carhon is formed from carbon dioxid. It seems much more probable, however, that the bacteria themselves fix the nitrowen in the roots of the plant and that it is then used as nitrates would be used fr $\mathrm{m}$ the soil. It is certain that these tubercle organisms can tix free nitrogen in cultures, and there is no reason to suppose that this power is lost when within the roots of a legume. Furthermore, it seems as though the plaut actually uses the contents of these tubercles, for at the end of the season the tubercles are found to be much softer and shrunken, and are practically emptied of their mass of bacteria.

\section{EFFECT OF TUBERCLES}

It is a weil-established fact, and has been shown by a number of independent investigators in rarinus parts of the country, that the lemminous crop which bears tubercles will exceed a similar crop with rut tubercles by from 100 to 1000 per cent; that is, a field of clover grown "n such ponr soil that it would only yie!d 201 prounds to the acre would he so in wisated by the presence of tubercle-forming bacteria that on exactly similar soil it would produce from $f(m)$ to $2(m)$ pounds to the acre, and this without any cost $w h$, tever for fertilizers and.with very little more labor. In adition to the increase of the actual weight of the crop, tubercles also cause the plants to 
flower and fruit earlier, and the number of seed produced is very much greater.

Thus it will be seen that it is worse than useless to attempt to grow any lecruminous crop without being certain of the presence of the bacteria which eaable the plant to fix free nitrogen. It would be much better to fertilize heavily and attempt to raise some more profitahle crop than to introduce clover or beans or some other legume for the purpose of enriching the soil. It cannot he too strongly emphasized that unless the tubercles are present the leguminous crop is of absolutely no more benefit to a soil than wheat or potatoes.

While these organisms are pretty wenerally distributed throughout the earth, and it is quite possible in many parts of the country to grow almost any leguminous crop and secure these tubercles, it is also true that certain regions are practically devoid of the right kind of bacteria, and that unless some artificial means of introducing the germs be resorted to the crop will be a failure.

\section{ARTIFICIAL INOCULATION OF THE SOIL}

In the past there have been two methods used in attempting to bring about artificial in culation. Naturally where a certain leguminous crop has been grown successfnlly for a number of years the soil will become filled with tubercle organisms, and by transporting this earth to new fields the organisms will thus become available for forming the nodules in localities where they previously had not existed. This was the means by which the soy-bean organisus were brought from Japan, and there are very few places in this country where soy is now grown that did not receive their inoculation, indirectly at least, from the Japanese soil.

There two serious objections to soil inoculations, however. One is the expense, for it reyuires anywhere from 50i) to 1.500 pounds of earth per acre to pruduce a satisfactory growth of tubercles, and if this has to be transported for a larire farm, the cost is almost probibitive. There is still another and more serious objection, however, and that is the danger of transmitting pl int diseases by this methol. Several of the more serious diseases which attack crips are readily conveyed in the soil, and there are numerous cases on racord where diseases of leguminous aud other crops have been introluced into regions previously entirely free from them through an effort to bring abrut a soil inoculation of the tubercle-forming organism. ('onsequently, if any safer and cheaper method could be devised for making these germs available, it would be most desirable.

A few years ago certain German iuvestigators put upon the market a product known as uitrayin, which purported to be a pure culture of the roottubercle organism. Lhese cultures were ouly adapted to specific crops, for it lizs heen held inat eac a kind of legumin rus plant had a special germ better adapted to produce tubercles upon it than any other form, and for this reasun it was necissary to use one organism for clover, another for peas, and so 0 3. T' Tis prepuration, nitragrin, has been used with varying success abroad. Some experiments seemed to show that it was of the greatest value, while others are complete failures in demoastrating its worth. The failures so far ou tnumbsred the successes, however, that its manufacture has been abandoned, aud it can nu longer be obtamed. A few attempts have been made to use these cultur.s in this country, and while some very satisfactory results were obtained, the number of failures was even greater than abroad, the 
varying condition involved in transportation and the length of time which elapsed before the germs could be used being fatal to abuut 'l per ient of the material imported.

\section{MIPROVED METHOD OF INOCULATION}

A little more than a year ago the investigation of these nitroyen-fixing bacteria was bersun in the laboratory of plant phys olory of the Bureau of Plant Industry, with the hope of discovering some method of artificially inoculating soils which were devoid of the proper organisms, and iasuring their producing the desired result. It was soon found that the method in use by the German investigators was not adapted to the life of the organism: that is to say, the use of rich nitrogenous food material, such as decoctions of the host plant, were not calculated to produce an organism which would fix free nitrogen from the air. It was found that while the bacteria grew luxuriantly upon such media, they became less and le-s active, until eventually they lost completely this nitrogren-fixing power. It seemed as though the large amount of nitrates in the media upon which they were grown made it no longer necessary to draw nitrogen from the air, and consequently they deteriorated until they became of no more value than the common soil forms. It has been found, however, that by gradually reducing the am junt of nitrogen in the culture medium it is possible to greatly increase the nitrogen-tixing power of these germs, and that by proper manipulation their activity may be increased from tive to ten times that which usualıy occurs in nature. Practical field experiments have shown that of two cultures, one grown on nitrogen-free media and and the other on a medium rich in nitrates, the first will produce abundant tubercles, while the latter will be absolutely worthless and fail to produce a single nodule.

\section{DISTRIBUTION AND METHODS OF USE OF CULTURES}

Having secured an organism which was able to fix such a lurge amount of nitrogen, it was necessary to devise some metns of preventing tuis property from being lost, as well as to enable the cultures to be distributed in sufficient quantity to be of some practical use. It is now known that the bacteria, when grown upoa nitrogen-free media. will retain their hign activity if they are carefully dried out and then revived ia a liquid medium at the end of varying lengths of time. By using some absorbent which will soak ul' millions of the tubercle-forming organisms and then by allowing these cultures to become dry the bacteri 1 can be s.nt to any 1 irt of the Lnited states, or the world for that matter, and yet arrive in perfect condition. ()f course. it is necessary to revive the dry germs by immersion in water; and with the addition of certain nutrient $s 1$ ts the orjerin 11 number of bacteria is greatly increased if allowcd to stand for a short time. Frequent y twenty-four hours are sufficient to cause the water in a pail to turn milky white with the number of organisms formed in that time. Thus, bys nding out a dry culture, similar to a yeast cake and no larger in size, the original number of nitrogenfixing bucteria may be multiplied sutticiently to inoculate at least an acre of land. The amount of material thus obtained is limited only by the quantity of the nutient water solution used in increasing the germs. It is evident, therefore, that the cost of inoculating land is very small. The principal cost is in obtaining the organisms, but the methods perfected by the Department of Agriculture now make it possible to produce these at a comparatively 
small cost. Special facilities for increasing the culture on a large scale are being provided.

The way in which this liquid culture may be introduced into the soil varies somewhat with the character of the seed torbe : used and the area of the field to be treated. With large see $d$ it is often more convenient tolsimply soak them in fluid and then after they are sufticiently dry to sow them in the orinary way. In other cases it is frequently more feasible to introduce the linuid culture directly into the soil. This may be done? by spraying, or perhaps a simpler method is to mix the culture thoroughly, with a wasonload of earth and then to distribute and harrow this in just ias a fertilizer would be hanlled. Inoculations of this character have been tried on a large scale in practical field experiments, and the results have been $s_{2}^{n}$ satisfactory that the Department of Agriculture will probably soon be able to begin the intro duction of cultures into such localities as are now deficient in tubercle-formine germs. It should be born in mind that such inoculations are usually not necessary in soil that is already producing tubercles. While the introduction of fresh organisms will generally considerably increase the number of nodules, the effect upon the crop is not appreciable, and it is hardly worth the expenditure of time and labor necessary to make the inoculation. Wherever lewumes that fail to produce tubrcles are being grown, however, or in those localities where the soil is so poor that legumes will not grow and because of the lack of the proper organisms they cannot make a start, „every effort should be made to get the bacteria into the soil.

\section{Corn Improvement and Selection}

We are now just in the wake of the wave of awakened interest in corn improvement which has swept over the country the past three or four years. During that time many new theories have heen advanced and abandoned, and even those which have stood the test of time have been constantly modified as we have learned new facts.

Corn men now grenerally agree that yield is the most important consideration. even though the bigh yielding corn may have few ior none; of the fancy points catalogued as essential to the "ideal ear."

The first thirg for a farmer to do, who intends taking up practical corn breeding, or selection is to find the variety that is best adapted and gives best yield under his conditions. There are hundreds of varieties, and that they vary sreatly in yield when grown uniler the same conditions is easily seen by taking up the report of any varicty test of corn conducted by the experiment stations.

It is today. an established fact that the selection, say 100 ears of corn from the very best seed obtainable, that by close ohservation and examination, that hut very few of such cars will have all the good qualities desirable in such a variety, hence the necessity of a test by one who is thoroughly learnted first in what constitutes a des'rable corn for the general farmer, but the tests that may be of mcst value to the farmer are first, heft of ear, secuni. legnth of coh: third, length aud s'ze of kernel: fourth, the amount of life and oil or fat bearing por'ions in comparison to the whole, lastly, the shape of the kernel. The surest test of value being weight of grain in comparison to cob. Pick first your best ear, having the most of the above points in your judgment, shell it carefully, weigh the cob and the grain care- 
fully making a note the comparative weight of each, shell as many such ears as you may wish, making careful notes of each ear, have a plat of ground thorougbly fitted, in which remember first, the finely prepared seed bed-long enough so that the corn from one ear may plant one row, have this trial plat as far removed from other corn as possible, that there may be no mixing of pollen, give this plat rich attention, allowing no weeds or barren stalks to grow. As soon as the tassels begin to show and the ears begin to set or form, keep close watch and if from any cause there are stalks that do not set an ear or more cut it out, do not in all jour plat ailow even one stalk of this barren yariety to have a chance to shed its pollen amongst the fertile growing stalks. In this manner you will have laid the founclation for your coming crops of corn. At gathering time plck in good season allowing it to stand as late as possible without being caught by killng frosts, being very careful to put each row by itself giring it some number or mark by which you will know the row in which it was grown Be very careful that you do not store it at any place where it may come in contact with other corn and be very sure that it does not freeze, at least until thoroughly dried and remember one fact that all corn for seed will keep better until such time as it is wanted on the cob. When it is $r$ ady to shell for planting first, take each ear carefully, weigh it beforeshelling and the same after, this will give you the correct amount of cob and corn. Showing which are the best, as to the heft of corn compared to heft of cob, which decides the worth or desirability. By following this method for a few years, you will have brought out a variety of corn to your own liking and one that will surprise you as I think that no other grain will show the great improvement in so short space of time as corn, nor pay as well for the work and trouble that will have been laid out in this direction. We are positive in our opinion that the above named rules thoroughly carried out year after year, will be one of the greatest investments and one of the most pleasant occupations that any farmer can enter into, upon his farm.

\section{Seed Corn}

Illinois' annual corn corp, about $240,000,000$ bushels, is raised on nearly $8,000,000$ acres of land. It required al most $1,000,000$ bushe!'s of seed corn to plant the corn fields of this state.

If the character of the seed has any considerable inlluence upon the crop produced, then the production and use of the best possible seed corn becomes a matter of tremendous importance.

What is the quality of the seed corn planted by the lllinois farmers? To this question it will be necessary to study the character of seed corn under several difierent heads.

\section{UNIFORNIITY}

As a rule little attention has been given to the character of the seed corn; little examination has been made of the proportion of the corn to cob, of the purity of color, the space between the rows, the filling out of ends, the length, circumference, or shape, or of any of the impstant points which go to make up a good ear of corn.

It has been found by seed corn growers that the length, circumference or shape of the ear can be varied at will by selection, and there is every reason to believe that these characteristics can be so fixed that practically ail 
of the ears in a field grown from pedigreed, uniform seed will be of approximately uniform size and shape. Further it has been found that the number of rows of kernels on the cob, the filling out of the ends or other characteristics, can be improred by planting from seed having these characteristics.

It has bee demonstrated that it is not good practice to plant small kernels of grain of any sort. Therefore, it is not good policy to piant the tip kernels. As the butt kernels usually vary greatly in size from the kernels on the rest of the ear, it is a good plan to shell ofl and discard both the tips and butts of the ears selected for seed. Again, as the butts of the ears mature first and the tips last, it is probable that the parts nave been fertilized by pollen of an early or late variety from some neighboriug field: so by shelling off the butts and tips, part of the danger of mixed seea can be avoided. In general, shell otf the small and the extremely large kernels, so that the portion of the ear remainıng for seed has kernels of approximately uniform size. With most varieties of corn, about one-half inch of butt kernels and one inch. of tip kernels should usually be shelled off.

\section{VITALITY}

$U$ wing to a late spring or early frosts, it frequently happens that the seed corn does not fully mature. In this condition the ear is likely to mould and decay, thus destroying the vitality of the grain. As the majority of farmers in Illinois allow the seed corn to remain in the general crib during the winter exposed to the sudden and violent changes in temperature, such corn, full of moisture, will freeze, and consequently the life of the germ may be weakened or destroyed. The seed corn in central Illinois, selected from the crop of $1 s ! s$, was so much injured in this way that the university tests of the vitality of seed corn sent in by farmers from this section of the State gave an average of only 76 percent germination. Such seed was not fit to plant, but as no provision had been made by the farmers for drying and properly preserving seed corn, and as this was the only seed available it was planted with a resultant poor stand, light crop, and a loss of protits.

Immature seed should not be planted for several reasons: First, such kernels do not contain as much plant food as those which are fully developed, and thus do not provide as much nourishment for the young plants which conserquently, do not get so vigorous and healthy a start as those from mature seeds. Second, the excessive moisture in the immature seeds renders them liable to begin to germinate in the fall in the crib, and thus use up a part of their strength: or a sudden drop in temperature may freeze the corn and destroy the life of the seed.

Seed corn should test 15 per cent ritality; i. e., of the seed planted in the seed bed 4.; per cent should grow. If the seed does not give this test of vitality a poor stand will be che result. Nor is it wise for the farmers to try to make up for poor seed by planting a greater number of grains, because of seeds which give a test of vitality many of those which do grow lack strength and vigor and will consequently produce weak plants. Furthermore, an uneven stand will sure result, some hills being over-crowded frequently with weak plants), and other hills being left with perhaps a plants at all because of the unequal distribution of the seed that will germinate. Seed of low vitality will inevitably tend to the production of a poor crop. It is important, therefore, that the farmer make a test of the vitality in order that he may know the quality of his seed. A most simple, effective, and practical method 
of testing the vitality of seed corn is as follows: Fill common dinner plates nearly lerel full of fine sand, pour water over the sand until it is more than saturated, shake gently to level the sand, allow it to settle, and then drain off the surplus water. Push 50 kernels into the sand in each plate, turn a smaller plate over the sand to prevent too rapid evapuration of moisture. and set both in a warm place. Keep the sand moist and in seven days all of the healthy kernels should sprout. By counting the kernels sprouted the per cent of good seed can easily be computed.

\section{PEDIGREE}

As a matter of fact the history of the development of most of the strains of corn now grown in the State, is very brief With few exceptions no record has been kept of the various crosses, and but few varieties have been selected toward a particular type for a special purpose for any considerable length of time. There have been but few systematic or practical attempts at improvement, and the result is that we are, as a rule, growing mongrel or scrub varieties. A few varieties however, have been carefully selected, in accordance with definite ideas as to improvements, for about a quarter of a century and have developed certain characteristics, distinguisting them from other varieties. In such instances it has been found that, if the corn has been selected toward a uniform standard type, the yield has been increased because of $\mathrm{t}$ be production of uniformly better ears. The yields of varieties tested at this experiment station from 1889 to 1900 inclusive, show the same result. Also enough has been accomplished to prove that almost any characteristic desired in a variety can be fixed by persistent selection, and that these characteristics can be continually 1 mproved by further selection.

The development of the per ecnt of sugar in sugar beet furnishes a splendid illustration of the possibilities of plant breeding. Starting with ordinary beets with about 4 per cent of sugar, the French and German seed growers by selection have increased the sugar content to an average of 12 to 1 it per cent, making it possible to manufacture profitably sugar from this source. There is little doubt that there are as great or greater possibilities in the corn plant, and that these possibilities can be as easily developed as the increased sugar content of the beet. The development of our present breeds of cattie and other live stock plainly shows how careful, systematic, and intelligent selection and breeding have improved those breeds. We have developed the dairy type and the beef type from the same source; the light and drafthorse from the same type of breeding and selection.

Corn responds to selection as readily as do beets and cattle, and there is no longer any doubt but that varieties of corn can be further improved by similar methods.

it has been found that the chemical composition of the corn kernel varies, and the experiments conductedlby this station have conclusively shown that the proportion of the constituents of chemical composition can be varied at tne will of the Breeder, "Improvement in the Chemical Composition of the Corn Kernel." In other words, it has been found possible to increase or decrease the proportion of oil, or of starch, or of protein, by seed selection. When seed high in protein is planted, a product high in protein is the result and vice versa. The same thing holds true with seed high in starch, or oil.

What is true of the chemical composition, is eminently true of the physical characteristics of the ear; for instance, the shape of the Leamiug kernel 
has been changed by twenty-five years of selection from the original shoepeg shaped kernel to a broader, deeper grain with a deep ident. Along with this variation in shape of kernel has gone an increase in length of ear, and a slight increase in circumference. Again, in the case of the Boone County White variety, the tips of the original corn were poorly filled. This fact was due principally to the reason that the Buone County white ears are very long. As an ear matures from the butt, towards the tip, the tip maturing last, it frequently happened that the pollen was all gone before the tips of some of these ears which were well tilled, in other words, the ears all parts of which matured in time for the pollen to fertilize them, the best samples of this variety have become well filled at the tips.

Yellow Rose corn was originally a medium to shallow grained corn but by constant selection toward deeper kernels and deeper dent, the variety has developed a very deep kernel with an unusually deepindentation. It has been found at the university through five years of experimentation, that the amount of husks, length of shank, size of stalk, position of the ear on the stalk, the number of leaves, in fact every physical characteristic can be varied by the simple selection in a short space of time.

At present our meager records show only the incomplete history of the parentage of the varieties of corn. It is just as important that we know the character of every part of the corn plant, as that we know every characteristic of the stalk strongly influence the development of the ear; and it is probable also that we shall need to know the nature of the root development in order to breed intelligently.

\section{HOW TO GROW SEED CORN}

The farmer who is especially interested in corn can well afford to grow his own stock seed. He can select for those qualities he particularly desires, adapt the corn to his peculiar conditions of soil and climate, and continue to produce a constantly improving grade of corn.

The first essentia in growing seed corn is, that one obtain from some reliable corn breeder 30 or 40 ears of highly bred seed, of the variety desired. Corn suitable for growing seed is difficult to obtain. It does not exist in large quantities, bicause of the high standard of perfection which must be maintained in its selection, and so it must be very expensive, but the farmer can well afford to pay a high price in order to get it for breeding purposes. It is absolutely necessary that the farmer obtain this seed corn in the ear, because it is impossible to judge accurately the quality of seed corn after it is shelled.

An acre or more of good land should be selected which is located at a distance of about 40 rods from any other corn field (unless thick groves or hedges are between), and, if possible, further, especially in the direction of the most prevalent summer winds, in order that the corn may not be mixed by the pollen from other variecies or from low grade corn of the same variety. After the seed bed is well prepared and the field marked both ways, plant the corn from each ear by itself, either in plots about 9 or 10 hilis square, or in rows lengthwise of the field. The planting is best done by hand, and must be so done if the plot system is adopted. A square field of 36 syuare plots of 100 hills each is a little more than 1 acre: or 28 rows of 127 hills each make practically an exact acre, if the hills are 3 feet 6 inches apart ezch way. 
Discard all tips and butts and any other abnormal or mixed kernels and plant each plot or each row with corn from a single ear. What is left of the ears may be mixed together and used to plant a border around the acre field to futher protect it from foreign pollen. This border is, of course, cultivated with the rest of the field. Keep each year a carefully selected typical ear for purposes of comparison and to show the changes effected year by year.

As soon as the ears begin to set and the character of the stalks can be determined, go through the field and cut out all of the poor, dwarfed, or barren stalks, and also aūy volunteer or accidental stalks which may appear in the field, so that the pollen from these inferior stalks cannot fertilize the future seed. The same object may be accomplished by detasseling these imperfect stalks just as the tassels begin to peep through the leaves.

Husk each plot or row grown from a single ear separately. Examine the ears closely and select ears for the next year's seed acre from those plots or rows having the greatest proportion of ears true to type. The ears which produce this large proportion of ears true to type must have a prepotency for the production of ears of this uniform type, and by planting ears from such a crop, which has inherited this prepotency, and by following this meth od of selection for a series of years, a rapid improvement will take place.

After the required number of the very best ears has been taken as described for the next year's seed acre, a considerable quantity of highly bred seed can be selected for common planting or for planting in a separate field to produce larger quantities ot stock seed. This stock seed being but one or two generations removed from the highest type of seed, will naturally retain qualities and preserve characteristics of the highly bred corn.

Two systems of planting, which may be termed the "plot system" and the "row system," are both "xsed and both will doubtless give good results. It is thought that the plot system may eflect a closer in-breeding, but whether this is true, it is desirable or advantageous, is not yet determined. For simplicity the row system is recommended. It has been used for several years at this experiment station in the above mentioned corn breeding experiments by which marked improvement has been efĩected in the chemical composition of corn, and it has been adopted by several breeders who are taking up similar lines of corn breeding.-D. Shanul, Ill. College of .Agriculture.

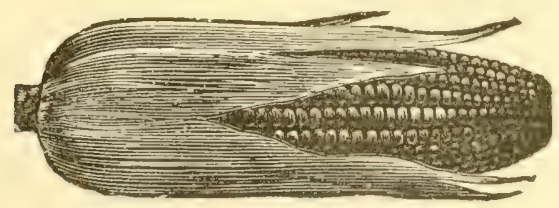




\section{Acslimation of Corn and How to Get Good Seed}

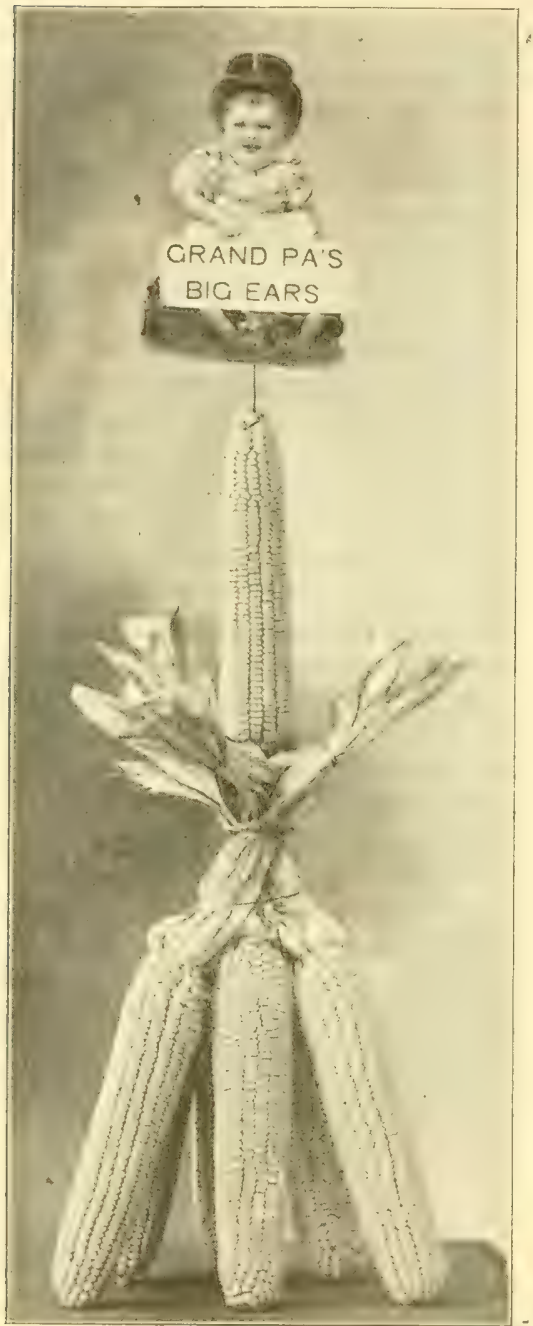

We are hearing a great deal said in regard to acclimated seed corn and of thoroughly breeded. seed corn and seed corn that will resist both drought, wet and cold, and many other points that to the practical thinking man seems very strange. There are leading men who are talking upon this subject and who are saying to their farmer friends, do not send away for your seed corn, but buy from your neighbor if you have not got it on your own farm and at the same time they are saying, plant thoroughly breeded blooded seed corn such as has been planted with the view that first, there shali be no barren stalks, second, a uniform color, size of ears, and with straight rows fully covering both tip and butt with deep grains finely set on the $c o b$, and so full of fat producing substances that the struck half bushels will weigh from 32 to 33 pounds. Do you for one moment think, that you can find a farming community where the ordinary farmer is growing corn with all or any great number of these qualities? The thinking man will at once say no, the ordinary farmer has not the time for all this, many of them are good judges of good corn, but how many know how to grow it to secure the above results, and how many of them have the time to spare in such tests even if they did understand the process fully: The next question then is, what is meant by thoroughly bred seed corn?? If we get the right iclea, it would mean simply that a man must plant but one kind and that grown at or near some particular farm or locality, for years, selection being made each year of those ears which show a strongly defined type. If this be done corn must be different from all other grain, in breeding vegetable or animal life.

We know from experience that breeding along these lines while it may give a smooth symetrical body it does not give strength, life or solidity. What in your estimation gives the best, strongest and heartiest cattle and 
hogs?? Nost assuredly not in breeding. Now the thinking practical man will choose first from the same strain to he of so kin from the miostrugred. We all know of the results of inbreeding bringing weak constitution unprotitable sickly stock: Then why not with corn? There seems to be a point in corn breeding which have not been brought to the attention of the people and to it we attach great importance. Our husiness for many years has heen the breeding and selecting of corn, for seed. Not the fancy kind for show, but that which the practical farmer wants, strong prolific and full of oil and life. What does the ordinary farmer care for straight rows or samencss of ears, so long as he gets a large yield, of well matured and sound corm, such as will meet the demands of commerce, give the greatest number of pouads of shelled corn per acre, fat his hogs and cattle make a big return on his investment, pay off the mortgage and allow him a fine carriage, in which to visit his friends or make his journey to town. The reputation of my corn has been universal for years, and it has been the wonder of many who have thought along this line, how it could be that my corn received the same recommiendations from north to south and from east to west, and yet to us there is no secret upon this subject. For years it has been my babit of sending to those who have grown our corn in Illinois, Missouri, Kansas, Nebraska, Minnesota and the Dakotas, to obtain from those states the best that have been grown, bringing it back and planting the same upen the pleasant ralley seed corn farm. This being the same strain of corn having been sent to these various different sections, and having become acclimated to their climate, being brought back here and grown upon our farm, gives it new life, new blood with strong vitality and prolific tendency, which it must in our soil and climate, and which makes it truly adapted to the growth of the best ancl strongest corn ever grown upon the face of the wlobe, ready for planting at all different points of the compass. This operation al drom the testimonials which we have receired from all those states mentioned fully convince me, that this is the true method of acilimating corn, that shall be a success from north to south and from east to west.

There is no man today but will admit that corn grown in our valley far out ranks any corn grown in any other part of the world. The have grown corm for the past thirty years, in this valley. We were many years ago convinced that the suil ind climate wou'd produce coln. better matured, stronger vitality, more prolific than any other section that we have ever seen. Tolay our most sanguine expectations are more than realized. There are now hundreds of thousands of bushels of seed corn being shipped from our city, to all parts of the U. S, Canada and Mexico and other foreign countries. It has required thirty years to demonstrate the fact of our theory along this line, but today, I assure you that no other section is as widely known for seed corn as the city of Shenandoab. What has thus firmly established this reputation and built up this immense trade? It must most assuredly be something substantial. Truth will prevail, if so our theory of acclimation, cultivation and selection must be right.

A large number of our readers, men as well as boys, are managing corn breeding plats, and to these we have a word of advice, two of them in fact: In most cases they will find where they have planted rows with one ear each that many of the rows are very much inferior to those adjoining. This means that the ear from which the row was planted was poor, perhaps low in ger- 
minating power, resulting in a thin stand, but more likely low in vitality. Its stalks at this time of the year probably from three to six inches shorter than the adjoining row.

These poor rows should not be allowed to produce pollen. Therefore as soon as the tassels appear go through and pull them out. That is, the tassels. You will need to do this about three times during the week or ten days in which the tassels are appearing. The stalks in this row will be fertilized by the pollen from the stronger rows adjoining or within a rod. This, however, is not the main object in detasieling. The main object is to prevent the pollen from these rows of low vitality decreasing the vitality of the better rows and thus reducing their value as seed for next year. Take your seed from the stronger rows and prevent their vitality from being reduced by pollen from the weaker rows. This is a matter of a very great importance.

Where our readers have not planted ears in separate rows, but have mixed the seed, go through and detassel all the poor stalks in the entire plat. We have always advised planting in rows because the differences between the rows of low and great vitality are plainly to be seen, and also because it is easier to detassel a whole row than it is to detassel a stalk here and there in the hill.

Another very important point must be borne in mind. The corn plant differs from almost every other plant in this: that it must have considerable of a stock before it will produce an ear of any value. Any stalk too small to produce an ear becomes a weed. The stalk is the factory in which the plant food is converted into grain, and must therefore be considerable of a factory that is, a pretty well developed stalk, before it will even attempt to produce an ear. You don't get a big ear on a small stalk, nor do you get a large proluct of anything from a small factory. It is different with grass. You may have an inferior growth of grass, but the grass that you have will be quite as valuable per ton as the grass taken from a larger crop. It may be better because it don't have so much moisture. The main object in growing corn is to produce the ear, and unless you have a considerable development of stalk you can't produce an ear of any size. In other words when the stalk is formed and the tassel and silks are dead, the plant is just beginning to do effeclive work. Heretofore it has simply been getting ready, and if it did not get a good ready then you can't have a good ear. For this reason, therefore, the corn breeder should cut out all stalks that have not sufficient development to enable them to start a good ear.

This is not practical in a field where corn is grown simply for commercial purposes. There is not time to do that. The way to avoid weak stalks in that field is to look after your seed plant and get seed of such vitality that it will , r oduce big stalks the next year. The weak stalks will have some value for fo der, if not for corn. Better let the weak stalks go in the field. In fact y vu car' $\llcorner$ do anything else, but avoid them by getting seed corn of your own uf such high vitality that unless some unavoidable accident happens to it it will grow a great big strong stalk and be ready to develop big ears in the field another season.

We hope our readers who are engaged in corn breeding will not forget these two points. They are very important when you come to think of the next year's crop. Good, vigorous seed and the adoption of our suggestion 
will help very much in the near future, not merely next year but for many years to come.

\section{Do Not Plow Too Deep.}

Last fall in order to demonstrate the advisability and importance of shallow cultivation in the latter part of the corn growing season, two corn plants were taken from tne field and mounted just as they had grown in the soil. All who have seen the specimens are convinced their previous beliefs notwithstanding that shallow cultivation is the only system after the second cultivation. The specimens taken for this purpose were selected from hills having but one stalk and growing under the most natural and ordinary conditions, such as are found in any average field of corn. One was taken up at the time that the corn was about three and one half feet high, the other when the shoots were coming out of the stalks. For convenience corn roots may be classified in two kinds, lateral and vertical roots or the feeders, and brace roots the lateral roots were found to be very numerous and from five to eight inches below the ground. They gradually took a lateral oblique course downward to about twenty to thirty inches in every direction and then went straight down.

The roots were found to have many fibers and rootlets penetrating the soil in every direction. It is these root hairs that get the food from the soil for the plants, these characters indicating the $r$ usefulness in gathering plant food from the surface soil.

\section{GROWTH OF BRANCH ROOTS}

The varieties of brace roots come out at the lower nodes about the time it begins to tassle, growing very rapidly and nearly vertical, with a slight outward curve. They are inclined to be very straight with few if any root fibers, terminating in a translucent delicate tip in th 2 moist sub-soil. The character and form of these roots ind cate that they serve two purposes, namely, to aid the stalk in holding the weight of the ear, and to get moisture from below. Their lack of fibers indicate that they are of little value in securing food. In the specimens that we took up these roots descended over five feet, into the sub-soil, thus showing their great penetrating power.

The lessons taught from these specimens are of great importance. In the ordinary method of cultivating especially the third time, the shovels are set deep and the soil ridged up against the hills of corn; this is of ten done to kill weeds, and because a farmer thinks he is helping the plants by such vigorous stirring of the ground. Now, what he actually does is to cut off threefourths of the length of those laterals or feeding roots, just at a time when the plant is exerting all its energy in stirring up food, in the ear and stalk, the roots in the center of the row are exposed or left with so little covering that they are injured by the sun and air. Evidences of this work are shown by the numerous white roots that accumulate on the cultivator shank. How many of the farmers who may read these lines, remember how after such a cultivation the leaves of their corn rolled up, they innocently believing that the heat and the drought were the cause, while most assuredly it was the cutting of the sustaining and feeding roots of the stalks.

\section{LOSS BY DEEP TILLAGE}

Just think what this means. Statistic tell us that the average yield of corn in the most favored states are unly about 23 bushels per acre. Ninety- 
four milliuns of acres considered. $N$.w if there were only one good. ear of corn to each hill, three feet six inches each way, we would average over fifty bushels per acre admitting that other factors eflect the yil ld Yet with from only two-fifths to one-half of its normal roo: system left the other threefifths to onc-half being destroyid by deep cultivating to do the work at the time the plant is at the climax of its growth it is litt e wonder that our corn does not mature and yield as much as we expect or by one-half of what it mignt. The writer has in mind two large f rms one on which seven to eight thousand acres of corn were grown the last seasnn. In both cases with the exception of a few acres, the corn was cultivated : s deeply as possible, the last time over with a re-ult that two-thirds of the crop d d not mature. The few acres given shailow cultivation produced well matured corn with a far greater yield per acre although under the same $\mathrm{c}$ ndition as prevailed with the above named exceptions. Is further illustration n cessary? To kill the weeds, cultivate deep and early, to conserve moisture and aid maturity cultivate shallow and late. Today we have'so many illustrations from reliable sources that we cannot help believe that the experience and results given in the above are wonderfuly true. Mist assuredly it is a great object lesson and one that should rot be forgotten by the thinking up-to date farmer.

The following cut $\mathrm{w} 1 \mathrm{l}$ give a fine illustration of the roots described so vividly in the above communication.-B!l. . L. Cotrell, Ioura . Anricultural colleye.

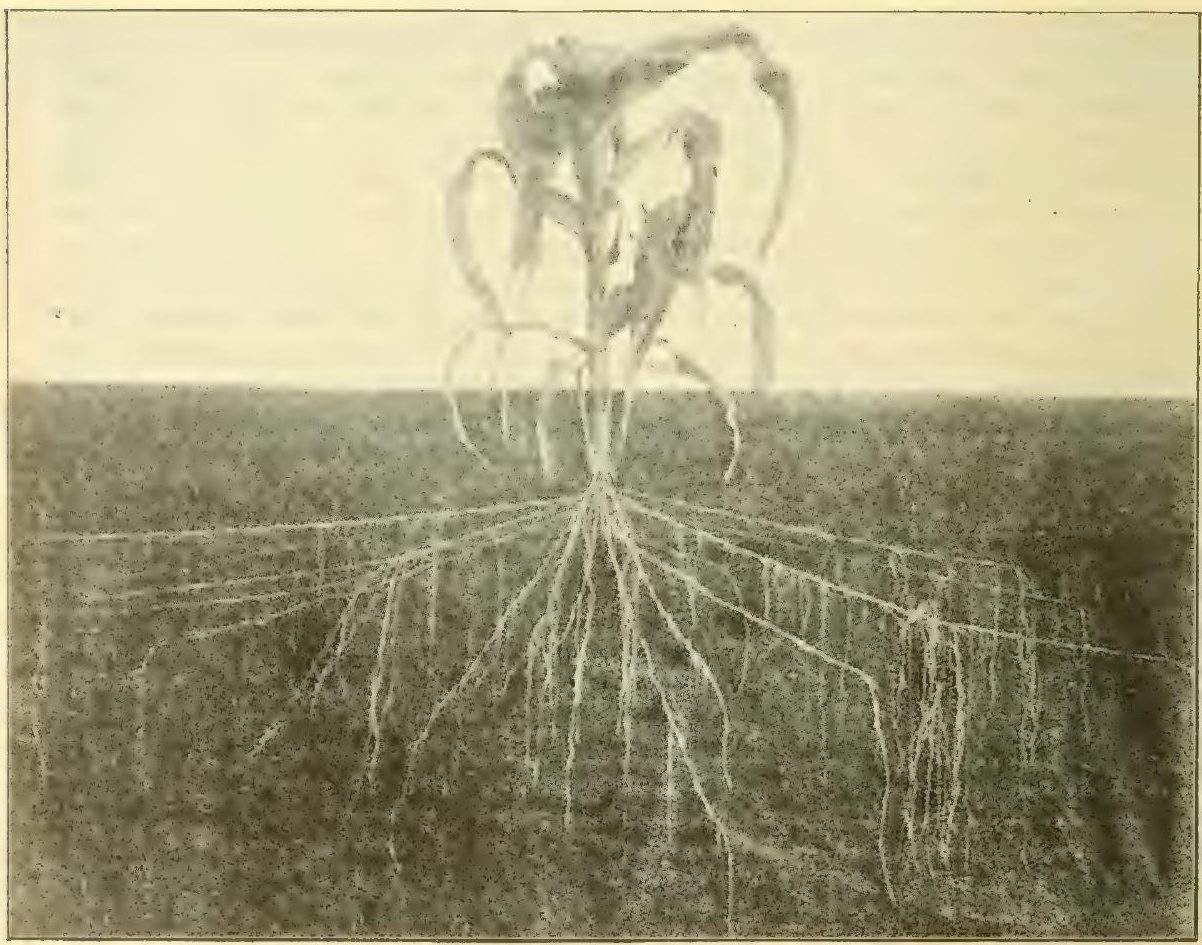




\section{The Tillage Problem}

The tillage prublem is one that confronts the farmer at the beriuning of spring's work and stays by him until the frost sto the flli, in fact it stays with him all the year to be most successfully carried out, he must know the land thoroughly and be ready at all times to give it such crops and tillage as is best adapted to each particular lot, each crop so planted that it will be in the very best condition for the one to follow, so that when one plants for the crop of the pres nt year he also has in mind the one to follow then if proper cultivation is not ofiered any kind of la d it becomes cloddy, hard and unproductive. A clod yields no nourishment to plants until it is cru hed, therefore. the physical condition of the soil bas much to do with the size of the crop. The soil may $b \geqslant t i$ led with an abundance of plant food, yet if it be hard and lumpz, it will not produc 2 maximum crops

The object of tillagre is two folà. First, to improve the mechanical condition of the soil, by breaking up and fining it, ss that the roots of the plants may ea:ily and freely find their way downward and through the soil: second, by giving warm h early in the sprins, by controlling a uniform conclition of moisture aud temperature through sut the growing season, afl'ording the soil mulch, and making available plant food, which is acted upon by air, water and fermentation, bringing it into a state of utility.

The tools used in tillage my be divided into th-ee general ciasses-deep, surface and compact. The ordinary p'ow bel ongs to the tools of the first class, and it may be truly said that good plowing lies at the basis of all successful agriculture.

True economy in farming is where large crops are produced on small areas, and when cultivated soil is deepened, th. root pasturage is correspondingly increased. By deep plowing we break up the hard pan, if too near the surface, and distribute food e'ements found in the sub-soil. Deep plow!ng should be done graduaı!y: and it may not be always best to nlow deep. Certain condition: must be taken into consideration; sand soils for instance and naturally mel!ow soils require les: depth in plowing. The furrow slice turned in plowing howev'r, shuld not be inverted, ut rather broken and pulverized in the turning. Clay land shou'd be plowed with ju lgm sat and never when it is too wet.

The time for plowing will d 2 pend upon t'ie season, the co dition of the soil and crops desired. Heavy soils, as a rule are henefitted by fall plowing and in many sections of our country such soils are often benefitted by being plowed several times. For most crops. it is better to do this some little time before the sfed is planted as a moder : tely c mpact soil is better than one of extreme loosenesś By employing the subsoil p'ow the advantages of deep tillage may be obtained. Eipecially is this true in preparing ground for orchards and root plants Subsoil plows are of many designs, and they are really plows without the moldboard and follow in the furrow uade by the ordinary p'ow, thus stirrin 5 the luwer soll and leaving it in the same position.

Surface tillage is usually confined to the uppermest three inches of the soil and may be carried on by the u ie of cultivators, harr ows, we zders, rakes, etc. It has for its object first, the making of a mellow seed bed where seeds maybe properly covered or plants set: secon ${ }^{7}$, the conservation of moistire by the producing of a soil mulch; third, it serves a means for the destruction of weeds and adds to the general improvements of soil conditions. 


\section{COMPACTING SOILS.}

The implements empl yed in the compacting of soils, are rollers, plankers or floats and their vilue depends largely upon the nature of the soil ${ }_{\text {sf }}^{*}$ and local conditions attending the seasons and the crops that are planted. With the light, loose, sandy or gravelly soils, where it is desirous to pack the particles of soil together, these compacting implements have an im jortant place.

Where land is seeded during a dry season the soil should be rolled in order to bring the moisture to the surface to hasten germination Where possible such a rolling sbould be followed by a light harrowing, thus restoring the surface mulch in order to prevent evaporation.

However beneficial this may be on some soils, yet all lands do not'respond to such treatment with equally good results. Clay land, for instance, may be injured by rolling, especially if fo'lowed by rain. If, however, land is plowed during a dry spell, it is a good idea to immediately follow the plowed land with a roller to crush clods, and to hoid moisture in the soil and"prevent drying out of the land. A good method with many crops is to roll before the seed is sown; then harrow, maki ig a good seed bed; afterwards drill in the grain.

Rolling serves a good purpose on many pasture lands in the spring, by pressing into the soil the roots of grasses that have bzen heaved"up by frosts during the winter. We have often followed this practice on meadows and pasture lands with excellent results. Wherever rolling is employed, the aim should be to restore the soil mulch by tillage just as soon as possible, which is shown in the accompanying cuts.

\section{Preparing the Ground.}

So much has been said in recent years in the agricultural press on the above topic that it is difficult to add anything new. On account of the different circumstances and conditions, it is impossible to lay down any one rule by which the farmer can safely be guided in the use of the harrow or the implements. His own past experience, if he has had any in this direction, will probably be his safest guide. Nevertheless, it is worth while to point out the object which the farmer may have in view or rather the conditions in the corn field which he should desire and which are essential to his greatest success, and then he can determine whether these conditions can be better secured by the use of the harrow or by some other implement.

A finely pulverized seed bed we find is very essential and must be had. There is no doubt todav that one cannot secure a too finely pulverized seed bed. In fact one may do the greater am nunt of their corn cultivation before the corn is planted by thoroughly working in this direction. One secures first, perfect assurance of a full stand of corn from the fact that each kernel is brought fully in contact with the soil in that condition that insures each grain the proper surrounding for producing a quick germination; second, in securing an even stand while if not so prepared and clods and trash are left and are brought in contact with the plantin $y$ the seed will from lack of moisture, too much air and heat be entirely killed or weakened and the gro * th retarded until such times as the rain has decomposed the clods and brought the soil fully in contact with the corn giving your corn from the same cultivation at least from one to two weeks variation in maturing, the latter often 
being caught by the frost, the damage being charged to poor seed when in fact it was due to the cultivation.

A satisfactory seed bed having been prepared and planted in due time with good seed, what next does the farmer desire? He wishes the corn to have the free use of every square inch of that field; he wishes freedom from weeds; he wishes to utilize the moisture held in reserve in the subsoil for the best pessible growth of the crop for the next ninety days.

When conditions are all right and the sun warm and the ground dry we would as soon as possible follow such cultivation with a corn plow or cultivator running deep and as near the row as possible without disturbing the corn, which will thoroughly kill all weeds that have been germinated and giving the ground between the rows deep cultivation crossing the same with a harrow, or better still the modern weed killer, a tool that we have found very efficient, but in its place with a grand effect one can use their harrow which gives a thorough cultivation until your corn may be from four to eight inches high when we use mostly the Eagle Claw or better still the Tower Surface cultivator. In crossing this with the weeder or harrow in this manuer the work is done most effectively, quickly and easily.

If the weeds are allowed to become deep rooted, then deep cultivation must be adopted, and this necessarily involves root pruning which, however advisable in certain climates and under certain conditions is certainly not advisable in the Mississippi valley. See cut of roots.

Once more we call the attention of our readers to the fact that a dust mulch of two or three inches shuts off to a great extent the evaporation of the water and utilize the main bulk of the stored water in growing a crop of corn. This must be done if we are to get the very best results. It is not possible for any man to grow a good crop of corn with the average rainfall, alone, of the Mississippi Valley. A good crop of corn can be grown only by utilizing the water stored in the subsoil, and to utilize this we must have resource to the mulch of dry dirt formed wherever you have surface, cultivation following a well prepared seed bed and shallow cultivation "cantot be adopted unless the soil is thuroughly prepared before planting. If planting is done amidst a crop of weeds, these in all probability will be so firmly established as not to be disturbed by the shallow shovel. Under such circumstances it is our practice to use deep shovels to destroy the first crop of weeds before the root system of the corn is developed to an extent that will render them liable to injury. Indeed, I would advise the complete destruction of weeds at all hazards, although it is much better to do this when they are young and tender.

There is another factor that should receive some attention, that is the leaving of the surface soil as sw, oth aüd level as possible after every plowing. A ridged surface exposes more soil to the drying action of the sun than a smooth one, whic 1 is another argument in fav, $r$ of shallow plows. This may seem a snall mat'er and jet the difference between success and failure in any busines; is often due to the attention paid to details and to "small things."

\section{Maintaining Fertility of the Soil}

To the farmer who has very rich land, as is the case in many parts of the west, the maintaining of the soil fertility may not seem of much importance, but in the course of time he will come to know how very important it is just 
as the New Whand farmer has long since learned. Many farmers in the westerustatis are already noticing the decrease in the yield of crops from older lands. and if hetter methols of farming are not resorted to, it will not ba math jears hore the application of commercial fertilizers will be necessary

The fertility of the soil is one of the great corner stones of prosperity to the people and the wealth of the nation is dependent upon it. We should be cartul w w better methorls of cultivation and return as much plant food to the soil as we take from it. The term fertile, as it is generally used, means the ability of a soil to produce crops. Although a sjil may be rich in plant foul it is uot reilly fertile unless the elements that coustitute this food are in available form.

The fertility of the soil may be maintained in many ways. First, let us investimate dilferent methods of tillage as to the etilect of each upon soil fertility. Many farmers harrest their : :ops early enough to let the land be fall plowed while others d n not work the land in the fall at all. The man who cultivates his land in the fall is the man who raises the largest crop from a given arca. lail tillage loosens up the land so that the water fiom the melting snow soaks into the ground, the land freezes and thaws to a greater dejth, which is very beneficial to soil that has a scarcity for available plant food. Fall plowing, also, turns up the subsoil to the action of the elements, and not ouly brings this soil with the dormant plant food to the top, but pulverizes it and breaks up the soil granules, so as to exposé much new surface of the soil grains t. the action of the elements. Thus tillage helps greatly in maintaining the fertility of the soil.

The rotation of crops nas been given much attention in the last few years by the leadingr farmers. Taere are several practical systems of crop rotation and of course the one to use is the one that best fits your condition and locality. Sil will not stand continual cropping without deterioration to some extent. Hery rotation should have some pasturage or meadow grass in it. C'hange the meadow or pasture from field to field as often as it can be profitably done. More than two grain crops should not be raised in succession from the same li ld if it be possible to raise some cultivated crop or some legume crop A catch crop or cover crop can easily be worked in between graincrops and with great advantage in most cases. If necessary, plow catch crops under for green manure. If possible, use a legume crop, either to harvest or for green manure, such as soy beans or cow peas, since these crops ank considerable nitrogen to the soil. Legume crops of one kind or another shou'd enter into all rotations, for nitrogen is one of the chief constituents which most soils are deticient in.

Barnyard manure is a so'urce of fertility which is sadly neglected by many farmers. If the crops if the farm are fed to stock and tae manure returned to th. lut in worl contition, the problem of maintaining the soil fertility becomes much simpler. Quite often the manure is piled up where the rain will percolate through it and take out the nitrates and other valuable constituents, carrying them down the ditches and into the creek or river. If manure canno: be hauled directly upon the land as it is made, it should be stored under cover or in a cement basin so that the liquid manure may be saved. The cheapest and best way to handle it, however, is to haul it out just as often as possible and if there is no cultivated land to receive it, spread 
it on the pasture and make two blades of grass grow where one grew before. Manure adds humus to the soil and humus is what much of the worn out land needs.

Commercial fertilizers are very expensive and farmers in creneral cannot afiord to use them where they have to compete with the farwer who has kept up the fertility of his soil by cheaper means and methods. Chemical fertili\%ers, however, are used a great deal in truck farming aud warket yardening to good advantage. Since so much depends upon the products of the soil let all of us who are interested in agriculture, strive to keep up the fertil!ty of the soil and thus help to increase the wealth of tha nation, and in adcition reap our own large harvests.

\section{Select And Care For Seed Corn.}

It is chosen before being injured by frost and kept in artifically heated rooms. Iowa.

Mr. Cownie tel!'s how the matter is hanciled on the farms of the state of

Over in one of the state board of con:rol oficics, there are 30 or 40 cigar boxes full of earth, out of which are growing great lusty corn stalks. It is from the seed selected last fall for our farms. We did not wait to select our corn until after the Irost had frozen the life out of it. 'There were selected from the corn of the same farms twice as many bushels of corn as would be needed for seed, the spring following, and this work was done in the first week of October. The result is that we have out of the kernels planted in those trial boxes a stand of 94 to 9.5 pərcent, and when the ears which are slightly molded are thrown out and the time comes to plant we will most assuredly have a stand of 100 per cent We are careful not to plant on the state farm corn which is not perfect the way to get perfect corn is to select it in the fall before the freezing frost comes, then keep the seedin artiticially heated and constantly warm quarters; in this way you will have 100 per cent grain from grain so treated. I want seed corn that has been kept in the artiticial heat all winter, it is the best. We had corn selected at Cherokee, kept in the cellar there at a temperature of a 1:0 degrees. Every grain of it sproured and came un with sturdy stalks in good sea:on. It is imposible to go to the corn crib and pick good seed, it cannot be done. The time to pick seed is in the fall, as I have stated. The boa d of control is competent to discuss the seed corn proposition. The state grows something like 1000 acres The products are all chopp ad into fodder. The instructions about selecting see $\lambda$ corn, have been issued annually to the superintendents of the different institutions. Last year all but nne inst tution followed the instructions, it bught twelve bushels of seed but ii) per cent of a crop. The other institutions grew a magnificent crop.

The danger of delay in selecting the corn in the fall, is that when the frost comes it will kill the germ In 1901 it was dry, warm weather without frost. Corn pi ked at any time in the fall of the year would germinate and grow, healthy stalks. In $19(1)$ frost killed the grain, and last fall it did the same thing. Had the board waited until November or December to select seed corn, it would have gone without. As it is by selecting it early before the frost, preserving it in hot quarters all winter and testing it, in the earth in the spring it has a prospect for a perfect yield and a bountiful crop. 
Each farmer who reads these lines, ought to be more interested in the selection and care for the seed that is to make his crop for the coming year. As the man who is employed by the state of Iowa to look after those matters, on the one hand there is but the interest and honor to prompt correct action. While on the otber, the full conditions in fact all the dependence of living in comfort and welfare of the family, would prompt the rigbt effort at the right time. I trust my farmer friends will take a lesson from the ex. perience and warning given by the director of the farms of the great state of Iowa.

Again we give you the experience of one in high authority, "upon plant making in a Dutch garden, published in a recent number of Everybody's Magazine, which greatly strengthens the writer in an opinion which he long since formed that farmers pay too little attention to the improvement and care of their seeds they are to use in making their crops. The article describes very conclusively how a Dutch professor of the Universtity of Amsterdam developed a new variety of clover, bearing four, five and even seven leaves. What this will avail to the farmer whose substance comes from broad acres of clover land, is not diflicu?t to determine. As a fodder and enricher of the soil, the value of the crop wi.l be increas $d$ to a very appreciable extent. Good luck certainly will come to those who substitute this new varity for the old three leaf clover. Yet the painstaking professor did nothing which the farmer had he the time and inclination could not have done. He simply assisted nature who is always trying to improve, carefully nourishing a few plants which bore four leaves. He saved and sowed the seed of the new crop; only those that bore four or more leaves were allowed to go to seed and so the process went on. Soon five leaves became abundant and after years of patient culling out, stalks with even seven leaves appeared, but none were developed with leaves above this number. It has long been taught that like produces like, even in plants and the wise farmer has already learned that if he saves his seed corn from stalks that bore three ears, in his new crop will be a much larger percentage of stalks of the same kind, and some with even four. Should th: culling process be carried on a few years, he will arrive very closely to a permanency of the three eared kind. If the farmer plants small potatoes ye $r$ by year in order to save the large ones for the market, nature will at last give up and reward him largely with the same kind, d just punishment for his greenness. Care and labor in the selection of farm seeds are always $m$ sre thin recompensed. While the market is full of that which is good there is always a demand at a higher price for something better. A farmer of our acquaintance procured at some trouble and expense a variety of oats which yielded much better than that grown by his neighbor; although the market was dull he found no difficulty in disposing of his crop at a figure 25 per cent higher than the current prices. What he did, anyone of intelligence and of good judgment can do. Every farmer should at least make a specialty of one thing: it will not only lessen the monotony and relieve the drudgery of farm work but will also prove a diversion and put money in the pocket of him who undertakes it.

We trust that each farmer will have had a lesson upon the desirability of preserving his seeds with their full strength and vitality so that he may raise such crops as shall be sure of giving a large yield and desirable grain. 


\section{Planting Corn}

"Planting corn is a very particular part of corn growing and should be carefully done by an experienced hand."

During a recent trip through four of the greatest corn states the writer estimated the loss from this cause alone, at fully $\$ 100,000$ to each county. From many personal visits to numerous localities throughout the corn states, during the past few years I have concluded that the average annual loss occasioned by having the stand of corn too thick, or too thin, at a very conservative estimate, is fully fifteen bushels per acre. This would average about seventy million bushels that are annually lost in the total yield of our corn crop, owing to poor stands of corn. Too thick a stand of corn is just as poor a stand as too thin a stand. Many farmers not realizing the importance of seed corn of the highest possible germinating power, almost annually.use seed corn not of the best vitality. They usually delay the selecting, if selecting it can be called, until they are almost ready to plant, when they pick the foundation of their corn crop hurriedly, and in many instances carelessly depending on "luck" for a good stand. There is no mistake so often made by the great masses of our farmers as the putting in of too much seed in the ground. It seems to me many are trying to grow two or three crops on the same ground at one time This mistake is often made by old farmers who seem to forget the sad results of former years and in my estimation there is more loss occasioned by over seeding than from floods, droughts and storms combined. I have in mind one of our farmers, who the past year left to his hired man the planting of his large crop and he put in at least twice the amount required. This mistake was to him a dear experience. It would seem that any man who had farmed for years would do better than to trust the planting of their corn to inexperienced hands. They had far better take the management of the planting of the corn. The result of biring inexperienced men in this direction was that at least twice the seed was planted that should have been put upon this piece of groudd. Every kernel grew; the season was wet and a wonderful growth of foliage was made and a vast number of ears were set by the thick foliage, and the wet and cold weather prevented so much from maturing. The result was a large number of nubbins and soft corn. Had this corn been planted with three to four kernels to the hill this one farmer would have had $\$ 1,000$ to $\$ 1,500$ more for his crop than he actually received from the same. This is but one of the many thousands we might mention and while many may not have as poor results as this farmer did, there are but few who have not suffered from the same cause, making it sure that if the farmer cannot attend to this matter personally he ought to hire one who cannot on?y drive so as to plant a straight row, but be sure that his planter is at all times doing such work as is wanted, as the right amount of seed placed at the right depth even dropping by the check row, or even distances apart with the drill. This in a great degree governs the returns that the farmer is to receive.

Very often again we have to face the problem of replanting; poor seed, cut worms and moles are what have to do with our stand so that very often we have a corn field that seems to the ordinary observer, as you will often hear said, it just amounts to no stand. What is to be done? In our opinion it is this: do not try to fill in or replant, but if you have what seems to be a half a crop give this good care and it will surprise you with great big fine 
ears of corn at wathering time, but if in your opinion it must be replanted put in the corn plow and the chag and plant it over with an earlier seed. In this way you may make it, but I always take the first planting if there is any show.

The careful farmer will first thoroughly test his seed corn before planting time, that he may know from the first what to expect from it, then he will he sure to so test his planter that he linows to a certainty the amount it will drop, then knowiag his ground he is fully prepared to get such a stand as he wishes. The next thing to consider is, what is a stand of corn?

Three to four stalks in a hill, when check-rowed, and the same amount when listed or irilled, makes a gool stand. That means one stalk where the rows cross ancl one stalk in the midile if drilled or listed. This is all I want on any soil or in any year. This amount, if of a large sized variety, planted in soil sufliciently fertilized to prouluce a full crop, will give a yield from 75 to 100 bushels per acre in all seasons that are favorable.

I often pass fields of corn with from four to seven stalks in a hill, whether check-rowed or drilled. No field can produce a good crop under such circumstances. When you observe this state of affairs you will see a lot of slim half starved stalks of corn, with two and maybe three, half starved, chaffy ears to a hill, the rest will be entirely barren. If the season be a dry one, very many of the hills will be without an increase.

On two fields, both having the same appearance as to amount, one was replanted the other not, and the one not replanted, had by far the better and more corn. The cases are very rare indeed, when it really pays to replant. We fincl in iny tcclay who advocate cutting and saving all the corn fodder but I contend that the farmer is only entitled to his share, the ground being entitled to enough to keep up fertility and manure a crop. I am of course growing corn for seed, I want all the vitality and strength left in the corn, as only a strong vigorous corn produced by a strong soil, will make such seed as can be depended upon, for the best results.

I find after land has heen so treated for a few years, corn will stand a six weeks' drouth and never faze it, and it seems to grow better each year it is thus treated. The reason I assign for it is, that turning under the stalks each year before they are fairly dried they soon rot which adds such qualities of fertilizing matter to the soil thit the growing plants are sovigorous that they sebd their roots deep into the subsoil and gather moisture, while plants growing on enfeebled soil have a weak st $t$ of roots, not penetrating to any great depth, and when (lrought strikes them they fire up) and produce nocrop. The bist results are what we all wish-try my plan and see what it will do for you.

\section{Early and Late Planting}

In old farmer named silomon, who must hare run an experiment station on his own account. laild duw s me rules for planting for the gruidance of his tenants: "In the morning saw thy seed, and in the evening withbold not thine hand; for thou knowest not whether shall prosper, either this or that, or whether they both shall ha alike good." It is simply another way of saying plant your corn when you are ready and do not try to guess whether the early planting or the late planting will be the best.

In 1901 late planted corn yielded the best crop, while the eariy planted corn was largely a failure. The late planted escaped the extreme heat which 
killed the tassels of the early and got sume benefit of the later showers. From this many farmers jumped at the conclusion that late plantediorn would be hest and planted their corn in $190 \%$ a week or ten days later than was necessary. The result was corn caught by the frost, or, if not, soft and chaffy.

No living man can tell when he plants his corn whether the early or late will be best. There is a limit before which he cannot plant successfully because there is not heat enough for germination; there is a limit after which it is useless to plant corn for a grain crop, for we know that except in years of abnormally great heat there will not be enongh heat units to mature it. Corn may be planted in central Iowa from the first of May to the first of June, preference being given by most farmers to the midule ten days in May, beginning with the 10 th on stalk ground and ending with the 20 th on sod. These periods will vary with latitudes either north or south, but in our opin. ion fully as much or more in nearby or adjoining farms, from the fact of the great difference in the lay of the land, the advantages of drainage, the methods of cultivation, etc. Each farmer to be successful and who makes his farm pay must thoroughly study his land and use good judgment as to what crop wi'l be best for each lot or field, then he must plan his rotation of crops in such a manner that each shall receive the change necessary or what might be termed rest. That will assure the bast results on such lands, as are liable to be cold or backward. I recommend thorough fall plowing on the great majority of land through the Mississippi Valley. In this way one may get an early start with the disc or drag. The next great advantage will be the thorough packing of the soil which has a great bearing upon the coming crop of all that portion of territory. By thus stirring the top early, the soil is being warmed up many degrees above what it would be if not so treated but one thing sure do not forget the fact, do not plant unil you have a thor oughly prepared seed b?d. We are fully aware of the great anxiety of the farmer to plant his corn as soon as he hears the click of the planter on his neighhor's tarm, but I consider the man will be safest who makes haste slowly but sure. Those days spent in discing and harrowing and preparing the seed bed before planting will be a great saving of time a wonderful factor in the thorough germination of the seed planted and will give the man great results. We then ask you to be sure if you are right and when so satisfied, do your work thoroughly and quickly.

\section{Corn Planting the Foundation of the Crop}

Do the farmers fully realize the great gain or loss that may accrue from the good or poor planting? With seed of the desired variety, with kernels of the right shape and right chemical composition, and with the desired power of proper germination, one may be certain of the coming crop so far as the seed and placing of it in the ground are concerned. After the seed comes the planting and the preparation of the seed bed, is another important item in all successful corn culture. We have said much from time to time about the thorough cultivation, before the planting of any crop, and at this time will merely mention the fact that one half of the cultivation ought to be done before the seed is planted. We should remember that the better the ground is prepared the better the crop of corn is sure to be, and that added cultivation before planting will tend to lessen the amount required by the growing crop. There need never be any fear of doing too much work in the prep- 
aration of the land. It is better to be a little late in planting a crop, and thereby being thoroughly prepared than to seed exa:tly on time ur a little early with a lack of proper cultivation. It is of course, very desirous to plant in good season, but it is far be?ter to be a trifle late, if necessary, and have the seed go into the moist earth in a suitable condition. With careful management it is possible to have all these conditions fairly favorable.

In the planting of corn there is one thing that deserves special attention and that is in regard to the number of kernels that each hill shall contain or the distance between kernels when planted in drills. This of course is a matter of personal opinion among farmers, and will depend more or less on what special use the crop is intended for or the fertility or richness of the ground upon which the crop is to be grown. The size and final development of both the ear and stalk will depend much upon the amount of seed planted. That is the greater the number of kernels in a hill or the closer the seed in the row the greater will be the tendency towards smaller stalks and smaller ears of grain. On the other hand if the seeds are less numerous in either will or row the effect will be to cut down the yield per acre. It may be said that more farmers prefer that three kernels to the hill as they have in their estimations the best results. This number in fact is the one usually set on and composes the ideal hill of corn. In the drill it is quite desirous that the seed be not less than eight iaches apart on the very rich ground aud not more than twelve to fourteen on ordinary fields of corn. Each farmer will have to be his own judge as he knows the soil he is planting, and set his gauge as be may wish knowing the soil in which he is planting. This matter of uniform planting now becomes not only an important one but a particular one as well. It is a difficult matter to always have the hand or horse planter to always drop the right number of kernels at just the right place, regulate the machines as we may. This is especially so in the case of the drili. The drill or planter may work their best but the seed will not always appear as desired. However the planter is not wholly to blame for all such irregularities. We may by the selection of seed after thorough testing it in the planter determine to a large degree this matter of uniform planting. When the kernels are of different sizes aud shapes there is no planter or drill that will drop the exact number of grains every time, nor shou!d we expect it to do so. The seed planted should not only be selected as to the pedigree and germinating qualities but as to uniformity and size of the kernel. The small farmer who is only planting a few bushels of corn would best,after his seed has been selected and shelled by himself or someone who with a good eye and judgment, spread upon the table and run or pick over the same, tbrowing out all small, inferior, cracked or long, light kernels A few hours spent in this selection will be wonderfully paid by the uniform dropping, the better stand of corn and better yield in busbels. Upon every ear the kernels will vary more or less as to shape and size, according to their location upon the cob, whether from the tip, the butt or the middle. The use of the entire ear including tips, butts and middles will not give or cannot make a uniform seed. Where only the middle kernels are used and the tips and butts are discarded better results with the planter are bound to result. In a recent test made at the Iowa Experimental Station in this regard it was found that where the entire ear was used the planter dropped three kernels sixty-six times out of one hundred. Four kernels, twenty-five times; five kernels, once; six kernels, once; two kernels, six times and one kernel once. From this it will be seen that only 
sixty-six per cent of the hills contained $t^{2}$ ree kernels. When the tips and butts were discarded the planter dropped three kernela, ninety-two times out of one hundred. In another instance where corn was used in which the length of germs differed considerably on the various ears only seventy-five bills out of every hundred contained three kernels, while the same ears when classified when placing those with shallow kernels by themselves ninety-five per cent of the hills contained three kernels, in one test and in the second test ninety-fcur. These trials show very plainly the importance of uniform seed planting in reference to the plants ard also to the uniform stand of corn to be had. In drilling corn the results would not be so very different and in every case we should be careful about the grading of the seed that we are to use. The more uniform and even we can make our hills and rows of corn the more uniform and better will be our yield of both grain and stalk. This is a matter deserving great attention, and something we can all be more careful about in our future planring. The little money expended in thoroughly picking the seed in testing the planter will be repaid more than a hundred fold in satisfactory yield of corn.

\section{Corn Experiments}

\section{[FROM WALLACE'S FARMER]}

Mr. T. S. Hunt, a student of the Iowa Agricultural college, is helping us with our corn work, and has just noted an effect of harrowing that may be of value to our young readers who have wet fields.

We are making a test of planting corn, at different dates and are taking the temperature of the soil at the time of each planting. The experiment is being made on fall p'owed land. The day each planting is made the land of that planting is thoroughly disked and then harrowed. Our first planting was made April 221 and the seconả planting A pril 27th Mr. Hunt found at the time of the second planting that the land on which the first planting was made had a temperature of 55 degrees, three inches below the surface. While the freshly harrowed land on which the secoud planting was made had a temperature of 50 degrees at the same depth. This shows that disking and harrowing had the effect of warming up the soil 5 degrees in five days. Some years ago the writer had a large area of land in another state to be planted with corn. It rained almost constantly until May 15th, and the soil was stiff and cold. It was so late in the season when the rain stopped that something had to be done immediately to prepare the ground for planting. We started disc harrows as soon as the surface became dry although the horses' feet sank three to five inches in the mud. If this disked land had been allowed to become dry it would have been very lumpy. Just as the disc soil became dry enough to crumple it was cross disked and this left it dry and mellow enough for immediate planting. A small lot was left as a test until it became suficiently dry to work in the ordinary way. This $m$ de planting so late that the corn was a failure while a heavy crop was secured on the land disked while it was wet.

Professor King in his book upon the soil says that it requires nine and two-thirds times as much heat to evaporate water from the soil as it does to warm an equal quantity of water in the soil 100 degrees. Does not this explain why Mr. Hunt and the writer found disking so effective in warming up the soil. The disking made a good surface mulch that prevented evaporated 
water from the soil and the consequent cooling of it and turned the full effect of the sun's heat into warming the land. Th's would seem to indicate that each farmer should be able to so handle his wet soil in such a way that it shall be warmer up and will grow and produce a crop as heavy and in as good season as the dry land. Must assuredly there is something to think of along this line.

\title{
The Cultivation of Corn
}

\author{
[By C. P. HARTLEY, ]
}

\section{.1ssistant in Physiology, Plant-Breeding Laboratory, Bureav of Plant Industry.}

GENERAL REMARKS.

The object of this article, like that in the Yearbook* for 1902 , is to present to farmers some suggestions as to the surest and quickest means of increasing the production of corn per acre. The writer feels certain that it is possible within a few years to double the average production of corn per acre in the United States, and to accomp ish it without any increase in work or expense. It is not to be understood from this that it is desirable to double the present corn crop, but that it is desirable to produce the same yield on a smaller number of acres and with less labor. If 60 bushels are raised on 1 acre instead of on 2 acres, the labor of plowing, harrowing, planting, cultivating and harvesting is greatly reduced. Some farmers produce from year to year an average of more than 60 bushels per acre, but the average of the entire United States for the pist ten years ( $23 \frac{1}{3}$ bushels per acre) shows that many are annually harvesting less than balf this quantity. Since the average crop in the states best adapted to corn grow'ng is bu: little above the general average of the entire country, it is evicient that the average is not lowered to any wreat extent by the poor crins in sections unsuited to corn growing. Noreover, the yield peracre in the New England States, with their poor soil and short growing season, is greater than in any other part of the country. This clearly indicates the possibility of greatly increasing the yield per acre in the corn belt. This is especially easy of accomplishment in the Southern States, where the present average is low and where the growing season is not shortened by frosts.

Practical corn growers will understand the impossibility of giving specific directinns regarding the best methods of planting and cultivating corn that would be applicable to any considerable portion of the United States. The soil or drainage of different farms is often so different as to demand different methods of culture. [See article] It is therefore only possible in a general article of this kind to tell what methods have been successful in some sections of the country and to discuss the general effects on the soil and crop of certain methods of plowing and cultivating, leaving it to the judgment of the grower to decide upon the best methods for his particular soil and climate.

The most valuable information regarding the growing of corn in any particular section can be obtained from unprejudiced observant corn growers of many years' experience: and the writer wishes to thank the hundreds who have so kindly given him such information. The fact that the experiences of growers in different localities and the reports of experiments from the various State experiment stations do not agree should not lower the 
estimation of the value of either. Such disagreement follows necessarily from the different soils, altitudes, latitudes and seasons. Conflicting published statements have caused some to cease trying to learn better methods from the experiences of others, but a study of the conditions will show good reasons for the conflicting results reported.

The methods of cultivation in general use in one section of the country differ greatly from those in another section. The implements and methods employed in Iowa are as different from those of Connecticut as these in turn are different from those of Georgia; and while these differences are to some extent due to the nature of the farm land or to the class of labor employed, they are to a still greater extent due to the conservatism of the farmers themselves. That certain kinds of cultivators or plows or methods of planting have been in use in Georgia or Iowa for many years does not prove that implements or methods found successful in other states might not be used there to advantage. It is much too common for a majority of growers in a locality to adhere to methods accepted as best simply because they have been followed for years. They often purchase a particular kind of plow, corn planter, or cultivator because it is the one in general use or the only kind for sale by the local implement dealer, without considering whether some other kind might not be better suited to their farms. Merchants or manufacturers are so familiar with the methods or machinery of their competitors that any time or labor saving system or device adopted by one soon comes into general use. A similar diligence and enterprise should be exercised by farmers. If every corn grower couid visit all the corn-producing states of the Union, the general result would be the discarding of poor and the adopting of improved methods. No section excels in all respects, but almost every section excels in some respect.

In the South Atlantic States the observant corn grower would notice the $u$ :e of terraces for preventing the washing away of the top soil. He would also see the advantage of spacing rows and stalks in the rows at distances suited to the fertility of the soil; and, where poor soil nec ssitates the pianting of the rows i) feet apart, he would percaive the economy of growing a soil enriching, leguminnus plant between the cori risws. On the broad prairies of the $W$ eitern States he would le arn methods of curtailing expenses by the use of plows, planters, cultivators and corn harvesters designed so that one man can work a large sumber of horses and thereby accomplish a maximum of work. With such imp ements one man c t1, without help, plant and care for 40 or 60 acres of corn in addition to his other crops. The same methois and implements are suitable for many farms where more tedious and laborious methods are now followed.

SOME LAND TOO POOR FOR PROFITABLE CORN GROWING.

While it is true that proper attention to seed selfition and methods of cultivation will grea-ly in :rease the average production per acre for all land now devoted to corn growing, it is equally true that the cultivation of corn will never be found protitable on very poor land for grain crops alone but may be grown on such land where the stalks a fodder have a large cash value for feeding. The plowing and cultivating of poor soil is as expensive as the plowing and cultivating of fertile soil. Corn growing should not te attempt- 
ed on such land until it is brought into a fertile condition by the growing and plowing under of leguminous crops, the application of manures, etc. In the meantime some of the crops that require less fertility than corn may be grown. It should be remembered that the nature of the corn plant is such that it will not produce grain unless the soil is rich enough to afford a considerable growth of stalk, and that the best yield of ears is not obtained unless the stalks have made a maximum growth. For this reason some other plants will produce small or fair crops on soil too poor to produce corn. A cotton plant adjusts its yield of int to the fertility of the soil, a small plant producing a small number of bolls containing lint of as good a quality as that from a larger plant bearing many more bolls. A hay crop is also in quite regular proportion to the fertility of the soil. This is not true, howerer, of corn. When poor soil dwarfs grass to half its normal size, the crop of hay is reducel by about one-half, but when poor soil dwarfs the corn plants to half their normal size it is probahle that there will bs little or no grain yield, and any ears that are produced will be small and inferior.

Fven in the best corn producing states there is some land so poor that farmers who persist in attempts to grow corn on it receive nothing for their labor. Such land, however, in a tew years' time can be made to produce good corn crops. The growers who are quickest to learn the futility of attempting to grow corn on impoverished land are those whose farms contain some poor upland fields and some fertile bottom land. They find it necessary to fertilize and renovate the poor fields or confine corn growing to the bottoms. In most regions creek bottoms and river valleys are particularly adapted to corn growing, as they usually have a fertile soil and a subsoil well supplied with moisture.

Another explanation of the low yield per acre on many farms is the amount of unsuited or unimproved areas frequently embraced within the boundaries of fields planted to corn. In many cornfields throughout the country may be seen portious or spots on which it is impossible for corn to thrive. Tnese may be clayey spots or swampy or undrained areas or ground adjacent to timber. It is too great a waste of labor to plow, harrow and cultivate such unproductive spots. They should be improved so that they will yield a profit, or they should not be planted at all. The poor clay spots should be enriched, the swampy places drained or filled, and the corn should be planted farther from the timber, with a strip of timber grass next to the trees. Many farms could be made more profitable by rearranging the fields in order to make them more uniform as regards moisture and soil fertility, so that the entire field may be treated as the character of the soil may demand. No field can be well tended if the corn rows extend through a portion too wet for cultivation when another portion is in best condition for cultivation.

MEANS OF PREVFNTING SOIL WASHING.

More land has been rendered unfit for corn growing by the washing away of the surface soil than by constant cropping. Soil washing must be guarded against if profitable crops are to be harvested from the same field for a number of years, and with proper attention in this respect the farm will become better from year to year. The effect of heavy rains is to wash out gullies and ditches and to carry away the soil and plant food as muddy water. If 
this is allowed to continue unchecked the fertility is reduced, the soil itself is carried away, and the land becomes less productive from year to year. One heavy rain will sometimes carry away from a field more soil than a man with a team and wagon could restore in a week. It is to be regretted that farmers in the newer and more fertile sections of the country are not as wide awake to the destructive effects of soil washing as they are in older sections, where the farms have already been injured by the rains of $p$ ist centuries, and where constant attention is now necessary to retain the fertility which is at some expense put into the soil.

ROLLING OR HILLY IAAND.

It should not be supposed that because land is rolling or hilly washing must take place. Some very hilly sections which have deep, porous soils, full of humus, wash but little, and that only when the ground is frozen to a considerable depth and thaws on the surface. Hard soils that do not readily take up the water that falls upon them wash much more than loose, porous soils. The most effective means of preventing washing is to cover the soil with vegetation and loosen the subsoil so that tre rainfall can penetrate and be absorbed instead of running otf. The rows of corn, moreover, should run at right angles to the direction of the slope. Terraces are also effective barriers to soil washing, and their use is to be encouraged. These methods could be profitably employed on the sloping lands near the Ohio and Mississippi rivers. It is the desire of most farmers to have straight corn rows, and on level land this is preferable, but on hills better success will be obtained by running the rows at the same level around the hills This will necessitate curved rows, but the c'xrves will usually not be abrupt enough to make cultivation difficu't; in fact, cultivation is thus rendered much easier, since it is not necessary to plow up and down the hill, which, to prevent soil washing, should always be avoided.

ABSORPTION OF RAINEALL.

The carrying away of soluble plant food and lighter portions of soil is not the only objectionable feature of soil washing. The water itself is likely to be needed during some portion of the summer. By loosening the subsoil and covering the surface with a growth of vegetation, the soil can be made so absorbent that the water will penetrate the ground and be held in reserve to sustain the growing plants during times of drought. It would seem that after a period of heavy rainfall, during which $s$ or 10 inches of water fell within a month, the soil and subsoil of all fields would be alike saturated, but such is not the case. The condition of the surface soil has much to do in determining how much of the rainfall will be absorbed. The condition of the subsoil is also important. If its moisture has been exhausted by lack of cultivation and injudicious cropping, it will absorb water more slowly than when it is already moist. Thus it is that the subsoil of some fields remains dry to a depth of several feet during a season of heavy rains, while that of otber fields absorbs water in sufricient abundance to sustain crops during periods of drought. To readily absorb the water that falls during times of heavy rains the surface soil must be loose 
and porous, so as to take up the water rapidly before it has time to accumulate, and hold it thus until by capillary attraction it is drawn to the subsoil.

Some very fine clay subsoils are so compact that they turn water almost as effectually as a slate roof. Such subsoils should be rendered permeable and the most $\in$ ffective and cheapest way to accomplish this is by growing deep-rooted plants; such as clovers, alfalfa, melilotus, etc. The roots of these plants penetrate the subsoil and, decaying, leave numerous ducts through which water from the surface soil will pass to greater depths. That this is exactly what occurs is proved by comparisons of plats of ground on which such plants have been grown with adjacent plats on which they have not been grown. The former plats are firm soon after heavy rains, because the water has found its way into the subsoil, while the latter plats remain muddy on the surface. Some subsoils are the reverse of those just referred to; instead of being too compact they are too open. A subsoil of coarse gravel may allow the water to pass through too readily, thus washing out and draining away the fertility. Such subsoils are not compact enough to supply the surface soil with moisture by capillary attraction. Soils of this nature are greatly benefitted by the plowing under of vegetable matter, which, besides adding greatly to the soil fertility, checks the rapid leaching through the subsoil and enables it to retain moisture better during dry weather. The application of vegetable matter improves the fertility and physical condition of almost all soils, regardless of whether the subsoil is compact or porous.

IMPORTANCE OF RETAINING SOIL MOISTURE.

The amount of moisture needed to produce a crop is much greater than would be imagined. In the case of corn, it is sufficient to cover the field with water to a depth of from 10 to 15 inches. (11) About three-fifths of this. quantity, or from t 5 to ! acre-inches of water, is absorbed by the roots and exhaled by the foliage of the growing crop.(b) Nore corn crops are cut short by an insufticient yuantity of available soil moisture than by any other cause. This is well demonstrated by the fact that fields situated by rivers or lakes in such a manner that the subsoil always contains sulli ient moisture seldom fail to produce gond corn crops. The greater portion of the corn-growing area, however. is dependent directly upon the rainfall fur its water supply, and it is for this reason that this matter is here considerid so inportant.

After the soil and subsil have become well supplied with m isture by the rains of fall, winter and sling, the next important cossderation is the means by which it can be retained in the soil constantly within reach of the growing crop. The effect of suashine and wind is to cause the moisture to pass rapidly from the soil directly into the atmosphere, and unless cultural methois are employed to lessen evaporation much of the soil moisture will pass into the air without benefitting the crop except in a very slight and indirect way. For the good of the crop as much of the soil moisture as possible p. 99 .

(a) Ninth Annual Report Wisconsin Agricultural Experiment Station,

(b) Experimental investigations into the Amount of Water Given off by Plants. Rothamsted Memoirs, by Lawes and Gilbert, Vol. I. 
should pass into the atmosphere through the plants. In this way it will carry the soluble plant food into the plants, whereas if allowed to evaporate from the surface of the soil it will leave the soluble plant food deposited on or near the surface, where it will be inaccessible to the roots until it is cultivated deeper into the soil or washed there by succeeding rains.

As the moisture from the surface evaporates it is replaced by moisture drawn from greater depths by capillary attraction, just as oil is drawn through the wick of a lamp to replace that which is consumerl by the flame. The rapidity with which moisture will evaporate from the ground depends upon the condition of the capillary tubes or pores that connect the surface with the deeper soil. Any dry blanket that can be placed between the atmosphere and the damp soil will check this evaporation. The most practical protection is a covering of finely pulverized dry soil 2 or 3 inches deep. By thoroughly loosening the surface layer, the soil particles are disarranged so that the capillary tubes are not continuous. In this condition the surface soil becomes quite dry and remains so without absorbing moisture from below, thus acting as a mulch and retaining the musture within reach of the plant roots. It is necessary that this soil mulch be fine, for, if composed of clods, air circulates between them and causes evaporation to take place from the soil below the surface. A rain, however, will wet the surface, causing the soil to run together and crust, thus restoring capillarity. This makes another cultivation necessary in order to renew the blanket of fine, loose soil.

FERTILIZERS AND CROP ROTATION.

The question of the chemical fertilizers best suited to the corn plant is too broad for aiscussion within the limits of this article. The corn plant needs plenty of food and for most profitable results should be grown on fertile soil. A soil lacking in plant food can, of course, be made to produce a crop of corn if the requisite amounts of nitrogen, phosphate, potash, and other essential elements be added and the soil kept in a good physical condition; but the growing of corn on very poor land is usually attended with very little or no profit, and the application of commercial fertilizers does not permanently improve the soil. It is usually preferable to spend a given sum of money in buying corn rather than to make the same outlay for fertilizers in order to raise the crop on impoverished soil. If the soil is of such a nature that the application of one or a few elements at a small cost will cause it to produce good corn crops, these elements should be supplied; bnt if the soil is little more than a foundation, to which must be added a large portion of the necessary plant food, corn growing should be suspended until the soil is permanently enriched by applying large quantities of barnyard manure or by liberal and contiuued growing and plowing under of leguminous crops rich in nitrogen.

Nitrogen, which is an essential element of plant growth and the most costly ingredient of chemical fertilizers, in a free state constitutes four-fifths of the atmosphere. By the aid of microscopic organisms $(a)$ leguminous plants, such as clovers, vetches, beans, peas, and the like, extract nitrogen from the atmosphere and store it in the soil in a form available to succeeding crops. This is one of nature's ways of applying fertilizer, and by work- 
ing in harmony with nature man can hasten these processes and render poor soils fertile in a few years' time and at but slight expense other than for labor. Soils enriched by the growing and plowing under of leguminous plants retain their fertility well, but no soil, unless it be a river bottom which is frequently renewed by overflows, should be planted to corn year after year. The fertility should be maintained and improyed by crop rotation and by the turning under of green crops, which can often be grown the same season with the crop grown for profit.

In sections where wheat, oats or other crops are harvested in early summer, it is almost always desirable to follow them with a soil improving crop that can be turned under that fall or the following spring. Clover sod, turned under in the autumn and then torn to pieces and well mixed in the soil by cultivation the next spring, furnishes one of the best seed beds in which to plant corn. This is the method employed by a Pennsylvania farmer who reports that his yield has not been less than 100 bushels of corn per acre during the past twelve years, with the exception of two seasons. He also practices frequent shallow cultivation in a manner well suited to conserve the soil moisture, and is confident that with average rainfall during fall, winter and early spring be can raise a fair crop without any rain from planting time until harvest. A field of his corn as seen in August, 1902, is shown in Pl. XIV, fig. 1, when it appeared that the yield would exceed 100 bushels per acre. A later rep ort gives 130 bushels as the average yield from 90 acres. Some implements used on this farm are shown in Pl. XIII, fig. 2-on the left a 4-horse or 5-horse cultivator, used in the spring for loosening and tearing to pieces the clover sod plowed under in the autumn, and on the right a planter made expressly to plant corn according to this farmer's idea of the best method for his farm.

Whatever may be the system of crop rotation, all fields which are subject to blowing or washing of the soil should be kept covered with some crop during the winter. This is usually advisable, even though the field is not subject to blowing or washing, and if the proper crop is grown during fall and early spring it will enrich the soil when plowed under. If oats are to follow a corn crop, clovers, cowpeas, soy beans, velvet beans, wheat, rye, or some other crop should be planted in the cornfield at the last cultivation, or as soon as the corn is cut. Although such crops may not have time to make much growth, they will protect the soil during fall, winter and early spring, and add to its fertility when turned under or uprooted by cultivation. The growing of beans, peas, clovers, etc., is a great help to the soil even though the seed be gathered or the vines cut for hay, but the turning under of the entire crop enriches the soil to a greater extent and on poor soils causes a very noticeable increase in yield for two or more years.

FALL PLOWING.

Fall plowing can not be recommended for all soils and localities, but should be more generally practiced than at present. If a cover crop or sod is turned under in the autumn, decomposition will increase the amount of

(a) "Bacteria and the nitrogen problem," by George T. Moore, Yearbook of the U. S. Department of Agriculture, 1902, p. 333. 
plant food available for the crop the next summer. "This is true to some extent even though sod is not turned under, inasmuch as the simple loosening of the soil admits atmospheric oxygen and increases chemical action upon vegetable and mineral matter. Fall plowing is one of the methods of combating grubworms, cutworms and cornroot worms, which are often destructive to corn. Because tne surface of ground plowed in the fall is drier at planting time in the spring than that of ground not so treated, it does not necessarily follow that there is less moisture in fall plowed ground. The fall plowing has enabled the rainfall better to penetrate the subsoil, allowing the surface to dry more rapidly. In the spring, fall-plowed fields usually contain much more noisture, but at the same time have a drier surface than fields which remain undisturbed until spring. In sections where there is much rain during the winter it is better not to harrow the fall-plowed land in the autumn. This is especially true of fine clay soils that run together and pack readily. In comparative tests of fall and spring plowing, preceding a dry summer, the fall-plowed fields have generally yielded better. The same is true of subsoiling. Deep spring plowing and spring subsoiling are likely to result in diminished crops, especially if done after the spring rains. The loosening of the soil to great depths admits air and facilitates the loss of soil moisture; it also interrupts the capillarity, so that moisture is not as readily drawn from greater depths, and during a dry summer there is not enough available moisture to support a good crop.

DEPTH OF PLOWING.

From the above, it is plain why there has been so much contradictory evidence regarding the best depth to plow for certain crops. For a deep, rich soil deep plowing is best, providing it is done in the fall or does not render the soil too loose and dry. For thin clay soils subsoiling is better than very deep plowing, because it does not turn the compact clay to the surface, yet at the same time loosens the soil to a good depth. The plowing should not be at the same depth from year to year, as by such a practice the soil is not mixed well and a hard surface is left at the bottom of the furrows where the horses walk and the plows drag. A little subsoil turned to the surface occasionally allows the elements to act upon it, liberating plant food, and as it becomes mingled with surface soil and vegetable growth the soil depth will be increased. To accomplish these desired results it is well to plow a little deeper each year for several successive seasons, and then for one season give a plowing at about half the depth of the deepest plowing. It is well to have the farm mapped, the various fields numbered, and records kept of the annual treatment and production of each field.

\section{PLANTING.}

Throughout all corn-growing sections of the country it is the general experience that corn planted early most often gives the best yield. Occasionally later plantings yield best, but they are exceptions. In 1902 the writer saw fields of corn in Georgia, planted in February, that yielded 40 bushels per acre, and others adjoining, planted two months later, that did not produce 5 bushels per acre. In the Northern States there is little choice as to time of 
planting. Corn must be planted as soon as the ground is sufficiently warm, in order that it may mature before early fall frosts. In the Southern States the growing season is long enough to allow planting at different dates, thus lessening the likelihood of having the entire crop cut short by drought. Growing conditions are more favorable in the spring, and corn usually produces better if planted at that time. Although the Southern summers are long enough to aflord plenty of warm weather, corn planted in the summer will ripen in less time and usually produces less than if planted in the spring. Fields planted early frequently escape attacks of the bud-worm, while later plantings of the same year suffer severely. As the result of many years' trials at different State experiment stations the best planting season has been found to be, respectively: Middle Georgia, March 15 to 20; Illinois, May 11 to 18; Middle Inrliana, May 1 to 11; Kansas, May 2; South Dakota, May 10 to 20; Iowa and Nebraska, April 25 to May 25.

Corn should, of course, not be planted in cold or wet ground simply because the calendar shows that the usual planting time has arrived: but by good drainare, fall plowing, etc., every farmer should strive to have his land in good condition to plant at the proper time. Underground drainage wil prove most profitable in the end, but as this is rather expensive it is some. times desirable to use low, flat land for corn before it is possible to have it tile drained. Sometimes such fields are plowed in small strips or "lands" 4 to 6 feet wide, and a row of corn is planted on the ridge or backfurrow of every land. This places the plants aboye surface water, and for this reason is satisfactory during wet weather, but the high situation of the stalks places them at a disadvantage during dry weather. The method of planting illustrated in fig. 3 gives more general satisfaction for such fields. The ground is backfurrowed in lands 8 feet wide, making thereby dead furrows every 8 feet. On each side, and 2 feet from each dead furrow, shallow rows are marked off, and in them the corn is planted. By this method the plants have drainage during wet weather and are better situated for enduring drought than when standing on the higher ridges.

A little more care can be exercised to advantage as regards chopping a precise number of kernels and covering them with mellow soil when the planting is done by hand, but the labor saved by the use of planters is so great that for profitable corn growing their use is indispensable. Moreover, if the seed bed is in the proper condition any good planter can be made to cover corn as satisfactorily as it can be done with a hoe; and, if seed ears having kernels of uniform size be selected and the small kernels at the extremities of the ears be rejected, good modern corn planting machines can be made to drop with sufficient accuracy for practical purposes. However, the yield depends to such an extent upon the proper number of stalks and their even distribution that too much stress can hardly be placed upon the necessity for selecting seed ears having kernels of uniform size and plates for the pl inter that will drop the proper number at the required distance. Every spring the planter should be thoroughly tested and adjusted until it will drop accurately the seed to be used. These are some of the many essentials that can be attended to before the rush of planting time arrives.

DEPTH OE PLANTING.

The proper depth to plant must be governed by the quality and moisture 
of the soil. If it is a stiff, heavy clay containing plenty of moisture at planting time, 1 inch is sufficiently deep; but if it is a light, open, dry soil, 3 or 4 inches is a satisfactory depth. If the corn is planted deeper than 4 inches much of the food suppiy stored in the seed will be consumed before the young plant can reach the surface and expand its leav's. Plants can not be made to send their roots deeply into the soil by planting the seed deeply. They can better be fortified against dry weather by planting the seed in a furrow: here is where the lister gets in its best work, covering it slightly, and then gradually cultivating the furrow full of soil as the plants grow. This requires some care, however, as the furrow should not be filled to any great depth until the plants have attained the height of a foot or more and are in a vigorous condition. This method of planting is especially well adapted to deep soils where dry weather is likely to prevail during the middle or latter part of the growing season. The lister, tne implement with which a large part of the corn is planted in the Prairie States, fulfills the requirements of this method of planting.

PLANTING WITH A LISTER.

The lister is used for planting fields that have been thoroughly plowed and also for planting directly in last year's cornfield or stubble field without previous preparation. This latter practice, however, is not recommended for shallow or stiff clay soils.

The results of a majority of the comparative tests in the deep soils of the states just west of the Mississippi river have been in favor of listed rather than surface-planted corn, and the increased yield of listed plats has been greatest in dry seasons. By planting in a deep furrow, as is done with a lister, weeds in the corn rows are more easily covered by cultivation, and as the furrow becomes filled by cultivation the root system is placed at a greater depth. The corn is thus better enabled to endure drought, and the stalks are not so easily blown down. On soils where corn can be listed without previous preparation of the ground, this method is profitable because of the labor saved, but it can be successfully employed only on very deep, loose soils. When the drill is attached to the lister, one man with three strong horses can do in one day all the work connected with the planting of 7 acres of corn. The drill is so constructed that it can be detached from the lister and used separately. By this means an additional man and horse are required to drill the corn in the furrows made by the lister. If the soil is stiff and heavy it should be well plowed and brought into good condition for planting before the corn is listed. A lister or a planter with lister attachment which lists two rows at once and makes a mark to guide the driver on his return, can then be employed. Disks or double moldboards, could be attached to the various makes of planters and check rowers, and thereby the corn could be planted in the bottom of furrows below the general surface of the field. For the reasons mentioned, this method of planting would be an improvement for many localities where extensive areas of corn are yearly planted by means of check rowers which leave the surface of planted fields smooth. See article entitled Prosperity and Expansion. 
PLANTING WITH A CHECK ROWER.

Perhaps more corn is now planted by means of a check rower than by any other device. This implement is adjustable, so that the spacing of the rows and the distance between the plants or hills in the row can be regulated to suit the requirements of the soil. By means of the wire chain stretched across a field one man and team can plant in straight rows in both directions across the field 12 or 15 acres per day, thus admitting of cross cultivation. Corn planted in this way can be kept free of weeds and well cultivated without costly hoeing or the cutting of weeds. A summary of numerous tests made by various State experiment stations shows that there is practically no difference in yield of corn planted in hills of several stalks each or drilled so that the stalks stand separately in the rows, provided there is the same number of stalks per acre in each case. The former system facilitates cultivation and the latter provides for a more equal distribution of roots throughout the soil. Check rowers are best adopted to large and comparatively level fields free from trees or stumps. Hillsides and sloping ground can not be planted in checks without increasing the liability to soil washing.

DISTANCES BETWEEN ROWS AND HILLS

The distances between rows and stalks or hills in the rows affect to a great extent the production per acre. A proper number of stalks evenly distributed, so that none will suffer from crowding and so that there will be enough to produce the greatest number of well-formed ears, constitutes the best stand for the production of ear corn. If planted thicker than this the weight of stover increases and the production of good ears decreases. If planted thinner the weight of the stover as well as of ears decreases. Smallgrowing varieties should be planted thicker than varieties producing tall stalks. The scope of this article precludes the giving of specific directions as to the best distances for planting the various strains of corn, but remembering that for greatest production rich soil requires thicker planting than poorer soil, each farmer must determine the best distances for his particular corn and soil. In 1897, 1898, and 1899 the Georgia experiment station obtained the best results by having the rows 4 feet apart and the stalks 3 feet apart in the row. In 1900 the conclusion was reached that for upland soils capable of producing from 35 to 40 bushels of corn per acre, rows 4 feet apart', with one plant every 2 feet, would yield a larger quantity of grain than any greater or less distance. As an average for eight years the Indiana State experiment station obtained best results from rows 3 feet 8 inches apart, with the stalks $10^{8}$ inches apart in the rows. On many farms of slight fertiliy in the leading corn states of the Mississippi Valley the annual yield is considerably reduced because the corn is planted as thickly as would be advisable on fertile prairie or bottom soils. Here, the thinner planting prac. ticed in regions generally less fertile could be adopted with advantage. Where the soil is so poor as to necessitate the placing of corn rows 5 or 6 feet apart, it is best to grow another crop between the rows. Pindars or peanuts, cowpeas, soy beans, or other leguminous crops are well adapted to this purpose. They enrich the soil and do not interfere with the growth of the corn. 
The distance for planting in a particular soil should be decided upon and che planter adjusted to plant accurately and regularly. Spots missed by the olanter, as well as those depleted by crows, insects, etc., greatly decrease che yield per acre. The custom of planting a little thicker than the stand f stalks desired is not a good one. It may meet the requirements for small oatches that can be thinned by hand to the desired stand, but hand thinning arge fields is too tedious to be profitable. If the seed shows a germination f 97 per cent or more in a thorough germination test and it is then properly lanted the stand will be almost perfect unless very adverse weather ensues, n which case all the plants will be so injured that the planting of the entire ield again will be preferable to replanting the missing hills and will be more asily accomplished. It is not only a waste of land to have missing hills in a ornfield, but also a waste of labor in cultivating them. If a field has been Irilled in but one direction and for any reason a poor stand is obtained, it can e replanted with a check rower set to drop one kernel at a time operated rithout the tripping chain. The check rower is driven at right angles to he rows of the first plainting and operated so as to plant just as it crosses ach row. For this purpose two men will usually be required, one to drive and one to trip the check rower as it crosses the corn rows.

\section{IMPORTANCE OF THOROUGH EARLY CULTIVATION}

The most successful corn growers realize the importance of thorough arly cultivation, thus preventing any check in the growth of the plants beause of weeds or crusted soil. The farmer should see that, from the time f germination to the maturing of corn, the plants are not subjected to any infavorable conditions, but are given an opportunity to make a steady, vigrous growth. If their development is checked from any cause they will ever fully recover, no matter how favorable the latter treatment. As a onsequence of heavy rainfall the stalks may increase rapidly in beight, and t the same time, for lack of cultivation or of plant frod, or for other reaon, they may be slender or of poor color. Thrifty corn plants are thick, trong, and of dark green color.

Horse weeders and harrows should be used when needed to break a surace crust or kill young weeds that start before the corn is up or large enough o be worked with other implements. During the first cultivation, or while he plants are very small, narrow shovels that throw the soil but very little hould be used, and fenders are usually found desirable to prevent the coverng of the plants (Pl. XIII, fig. 3).

\section{DEPTH OF CULTIVATION}

Many comparative experiments of deep and shallow cultivation have een made, and on the whole the resuits are in favor of shallow cultivation. here are but few occasions when deep cultivation is preferable. If excessve rains have packed the soil and kept it water soaked deep cultivation will elp to dry and aerate the soil. Breaking the roots of the plants must be voided so far as possible (Pl. XIV, fig. 2). If roots are broken the plants ill rapidly produce other roots, but it will be at the expense of the vitality nd food supply. After the plants have reached a height of 3 or 4 feet, the 
soil even in the middle of the rows should not be cultivated deeper than 4 inches, and 3 inches is usually better. For retaining soil moisture a loose soil mulch 2 or 3 inches in thickness should be maintained.

\section{FREQUENCY OF CULTIVATION}

The best answer to the question of how frequently corn should be cultivated is that it shou'd be cultivated often enough to keep down weeds and to maintain constantly a loose soil mulch till the corn has attained its growth. To this end a greater number of cultivations will be necessary when rains at intervals of about a week cause the surface soil to run together and crust. This crust must be broken and the soil mulch restored, or evaporation will soon rob the soil of its moisture. It is a mistake to think that the longer the drought the more frequent should be the cultivations. After a fine mulch of about 3 inches in depth has been produced, its frequent stirring is not necessary fxcept in so far as it is required to keep weeds from starting. The essential object of cultivation is to restore the soil mulch as soon after a rain as the condition of the ground will permit. If this time is allowed to pass and the ground becomes hard and baked dry, the crop will suffer greatly, for the cultivation of hard, dry ground breaks it up into clods, allowing the air to penetrate to greater depth and causing more injury than if such cultivation had not been given at all. All ob-ervant farmers have seen crops injured in this manner. Many crops are cut short by stopping the cultivator because the corn is too tall for the use of a double cultivator without breaking down the stalks. If the condition of the soildemands it, shallow cultivation should continue even though the corn is tasseling. See article entitled Do Not Cultivate Too Deep.

\section{Selection of Seed Corn}

\section{GOOD SHAPES OF EARS}

Fig 3 illustrates good forms of ears. These ears are well proportioned. Their butts and tips are good. The rows arestraight and the kernels uniform. The ears are full in the middle parts, showing strength, constitution, and good breeding. It is very $\epsilon$ ssential that an ear shows fullness in the middle portion, as this is the place where the greatest quantity as well as the best quality of corn will be found. Ears 1 and 2 would plant well together. Ears 3 and 1 are slightly better in shape than 2 and 4 .

The fact that the selection of seed corn has a broad bearing upon the amount of ccrn grown per acre, and fully governs the good or bad qualities of the same is without question; therefore, to those persons who are best fitted to make the best selections, at least to the general farmer, results have proven that he who has made the propagation and growing of corn a study, and whose mind runs in the right direction, who possesses a sound judgment and who is looking for that which will benefit the world at large, will receive the best results.

Selection is truly the plant breeder's magic wand and with its aid the ready thinking man has brought forth wonders; in fact, from the scanty yielding Indian corn he bas brought forth the mammoth golden ears, and from a yield of but a few h'ushels per acre, he has perfected that variety that will yield its hundreds of bushels. 
his lifetime to it with an indomitable perseverance he will most surely succeed and make great improvements. If selection is to benefit agriculture, it must be followed up incessantly for a type of corn that is not in a state of progression will very surely degenerate. It is true that there has been ever since the remotest beginning of agriculture a sort of unconscious selection, which is exemplified by the farmer when he takes the largest ear of corn from which to plant his crop, but this practice often leads to bad results.

A much better mode for the selection of seed corn is to go into the field and select from the first ears that are ripened, which are to be gathered from a uniform plant, healthy, strong and showing fully matured ears, not forgetting that the great point to keep in mind is weight of corn-not cob. The really effective part of plant breeding is intelligent selection, because it is effective. Selection gives the operator the opportunity of exercising his choice, and by proper exercise of his judgment and experience, he is able to aroid all needless conflict with the heredity tendency: in fact, he must work in the same direction with heredity in order to make his labor sufticient.

Although selection is of great importance in the development of a type, its oflice is of still greater importance in preserving that type; after a desirable variety has been secured, the ease with which it will degenerate will require the keen observation and careful selection with the same idea in view that guided the originator in his labors. We must therefore learn that eternal vigilance is the price of success, as man by his observation and experiments has transformed very many seemingly wortbless plants to beauty and goodness, but none more 80 than King Corn, as the riches of the Klondike make no comparison with the vast wealth we reap from the wonderful advance made in the yield by the man who has brought forth two ears where was but one before. I therefore consider that selection is the key that opens the great treasure box to the world. Hoping the above will strengthen my brother farmers to greater efforts and that all may reap the reward for the same.

\section{The Best Method of Corn Breeding}

The manner by which the general farmer may most assuredly get corn for seed best adapted for his farm and surroundings, a subject upon which we have written in other articles within this book, we give yet another article upon the same subject In our judgment a small plat by itself planted with the very best seed obtainable and thoroughly fertilized and worked and by the removal of all barren stalks detasseling all weaker growth, will in our judgment at once show its superiority and worth. There are a great many good farmers, who d" not believe that it will pay to detassel corn, that corn has always preduced barren stalks and that it will always continue to do so.

Some have a theory that the soil has something to do with the production of barren stalks while others are equally positive that it is due to climatic conditions, such as excessively wet weather. That corn has always produced barren stalks we are unable to dispute, because we have no figures that tell anything about it. That barren stalks can entirely be done away with in a given variety is very doubtful, at least this is true for a great many generations to come, but that the percent of barren stalks can be greatly reduced in a variety of corn, if proper precautions in seed selection be taken, the writer firmly believes. 
Experiments at some of our stations have proved this beyond a doubt. If we stop for a moment to inquire into the cause of barrenness, the most logical conclusion one can arrive at is to suppose that there must be a possibility to breed out $~ a$ tendency to produce barren stalks. "Like produces like" is a well-established fact in both plant and animal breeding. If we breed a Chester White sow to the Poland China boar, we would be greatly surprised should some of the offspring not resemble the sire in color and other characteristics. In other words, everyone is well aware of the influence of both parents on the offspring. The sheep breeder increases the prolificacy of his flock by selecting his rams and ewes that produce twins and the hog breeder prefers to cboose his boars from large litters for the same reason.

In the corn plant we have both male and female organs on the same plant. A barren stalk is one that produces no female organs or silks, but which does produce male organs or tassels. It is evident that a barren stalk is not a perfect one and hence the pollen which it produces partially partakes of this imperfection, and when such a pollen grain fertilizes an ovary, the result of which is a new kernel of corn, it is clear that this new kernel of corn must partially partake of the imperfection of the tassel stock. One would naturally suppose that 100 kernels produced by the union of the male and female elements from two normal plants would produce less barrenstalks than would 100 kernels that had been produced on perfect mother plants, but had all been fertilized by pollen stalks. Whenever pollen from barren stalks is allowed to fall upon the silks of other stalks we are simply propagating a bad character which ought to be weeded out as much as possible.

The above view of the situation leads to the conclusion that unless bar" renness is kept in check by detasseling that this undesirable quality would be increased to such an extent as to become alarming. It must be remembered, however, that we always have a great preponderence of fertile stalks in the field and that barrenness is only one of the qualities of a plant and hence may not always appear in the offspring, even though a tendency to produce barrenness is inherent in the kernel. In other words, this character may remain recessive for a number of years. Further, it should not be for gotten that it is only possible to transmit barrenness from the male side of the plant as the female must certainly always be fertile in order to produce kernels at all. These causes therefore operate against barrenness, increasing absve a ce:tıin reasonable pərcent. What we are to do, however, is to minimize barrenness as mucb as possible.

To illustrate that this can be done, we refer to some work accomplished along this line at the Minnesota Experiment station. This station has originated a variety of corn which is a superior yielding variety and which is also an early maturing corn. It is called Minnesota No 13 corn. For a number of years detasseling has be en carried on in the breeding plots with this variety and in 1903 it produced less than 1 percent of barren stalks, while other varieties, with which no care had been taken to eliminate barren stalks produced 20 percent of barren s'alks. Having established the fact that the tendency to produce barren stalks can be increased or decreased at will, the question naturally arises how shall we make use of these facts in practice? Will it pay to go through our main corn fields and detassel all barren stalks? The answer is, no.

At the same time we also say, don't select seed from the main crop, and 
one reason for that is because of the many barren stalks that are found there. Have a special seed patch or nursery for the production of your seed corn and in this nursery it will pay well not only to detassel all barren stalks, but to destroy all weak ones as well. If you have not such a seed patch on the farm this year, lay aside a strip along one side, or better still, a square in one corner of the main corn field and detassel all barren stalks there as soon as the tassels begin to appear and are well out of the sheath and before any of the pollen is ripe. Go through this seed patch or nursery every day or two for a week or ten days until the corn is fully tasseled out and each. day remove the tassels that have come out since the day before. By keeping up such detasseling for a number of years the tendency to produce barren stalks will gradually be decreased, and hence the yield will necessarily be correspondingly increased. Detasseling of the barren stalks should not be considered to increase the yield of the fertile or remaining stalks, as it will have noeflect on them whatever, but it will improve the crop in future years as has been shown above. This work is especially to be commended to those who took a good deal of pains with their corn last spring and who may have gone to considerable expense in introducing a good yielding variety of corn on their farms.

\section{BARREN STALKS}

Out of the five stalks in these two hills only one produced a good ear. Note how weak and sickly the non-productive stalks are compared with the productive one. Barrenness is one of the greatest sources of lo:s in corn growing. To the farmer who grows corn for the grain alone these barren stalks are worse than a complete loss. They not only deprive the productive stalks of food, moisture and light, but they produce pollen which fertilizes the silks of the good stalks and so reduces the vigor and future producing power of many of the good ears. Nubbins are simply a mild form of barrenness.

This subject of barren stalks is very closely related to that of "The Product of a Single Hill." (See Fig. 10.)

This cut gives an illustration of the class of stalks which produce the nubbins, or what is worse, nothing at all. The unproructive stalk in these two hills have kundreds of brothers scattered here and there throughout the field wherever the kernels from the ear that produced them were planted. Some of these brothers of course bore something but a large percent of the plants that came from that ear would be abut like four of those in this cutworse than nothing. ()n the other hand the stalks bearing the good ear would have hunireds of brothers threughout the field, which came from the same good ear it did, bearing - not nubbins or nothing at all as these are doing-but strong, vigorous stalks producing in turn, a large percentage of good vigorous ears.

This question resolves itself into one of getting rid of these unprofitable ears and of planting only vigorous ear-producing ones. On an average one stalk in every seven produces nothing because of barrenness. One acre in every seven planted to corn is worse than wasted because of these unproductive stalks. Yet a little time and care in selecting our seed corn-not a dollar in outlay is required-will materially lessen this enormous loss. We cannot pay too much attention to the careful selection of our seed corn. 


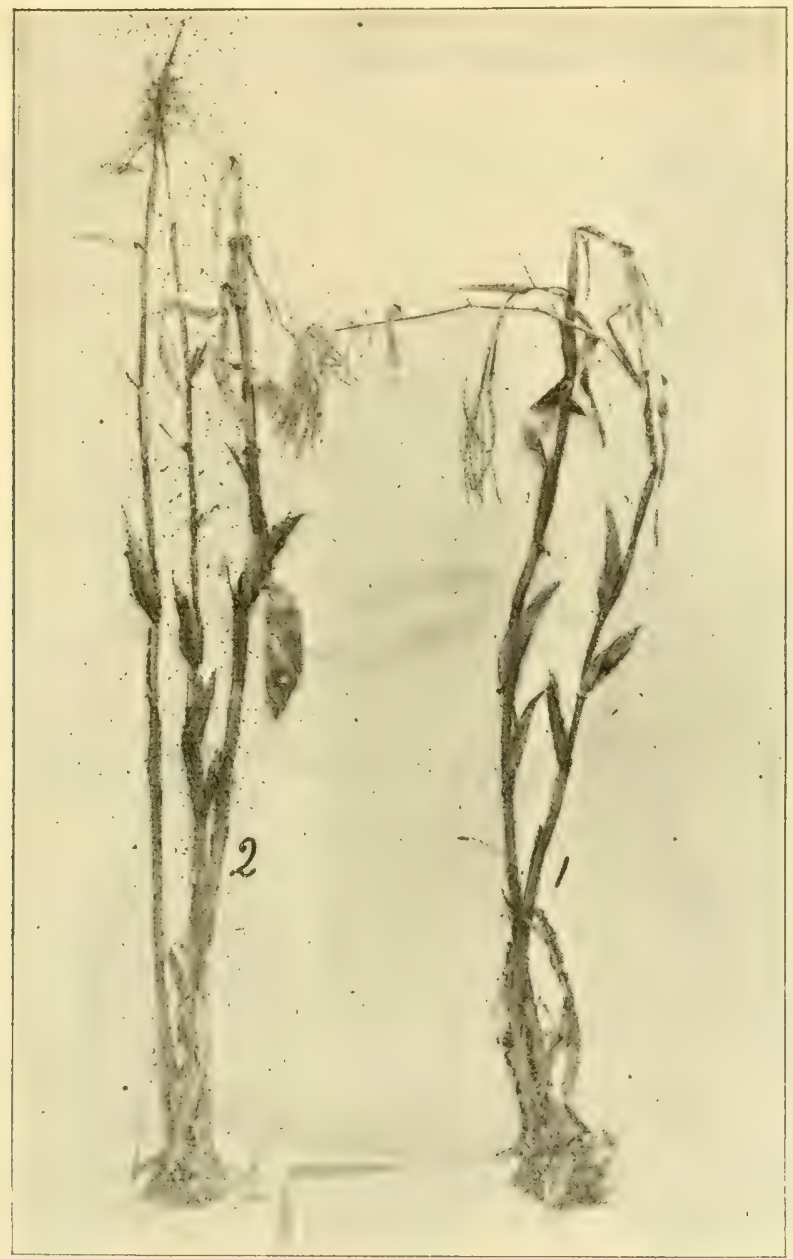

Fix. 11.

Prof. P. G. Holden of the Agriculture College of Iowa his fully studied the subject of barren stalki and their effect on the future yield of corn grown from pollen supplied from th॰m Seecut No. 11 and you will get a fair idea of his illustration from which y u will Jearn that the yield will be cut down wonderfully if the matter is not brought to the attention of the farmer in a forcible manner-thisu j ct tou hes the pocket-book. The results therefore are most easily br ukht to one's mind, in fact all the subjects brought out from illustrations selecter from the Year Rook are most vivid: such as you may find at any time in your own or your neighbor's cornfieln and coming as it does from so eminent and reliable a source as to b? contirm ne proof of its worth. It is said that the b sok learned farmer is no good. He does not deal 
directly with the farm but in this case we have the farm and the educated man combined. Study this matter fully, it will do you good

J. B. ARMSTRONG.

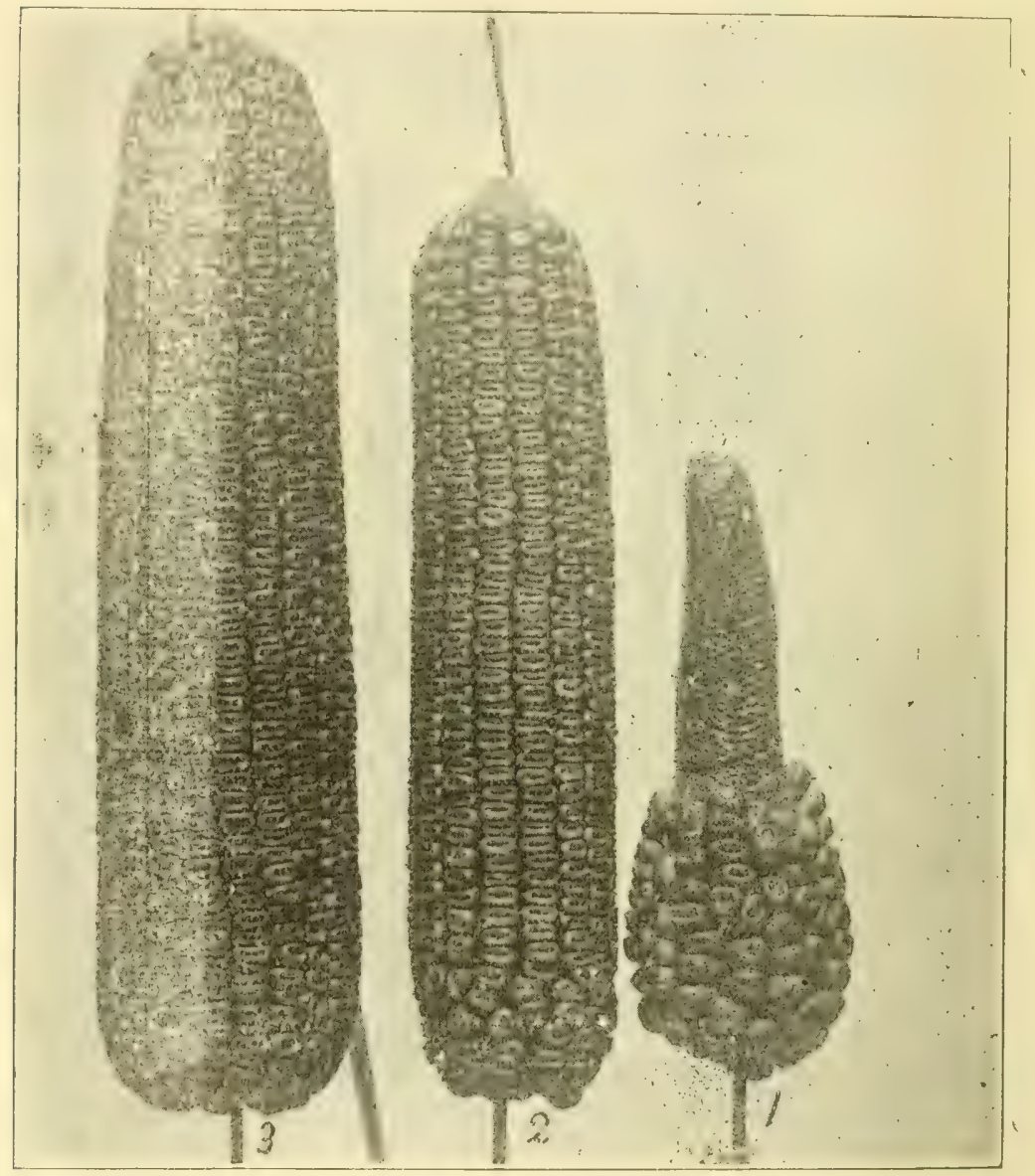

Fin, $1:$

PRODUCT OF A SINGLE HILT,

Fig. 12 illustrates what is too often seen in a single hill-a good ear, a poor ear and a nubbiu. We have seen this so often that we never stop to think what it means. Why do not all these stalks bear ears like No. 3? Being in the same hil, the conditions of soil, climate and moisture must have been ex ictly the same One could not have received more thorough cultivation than another. From the time the corn was dropped there was no good reason why Nos. 1 and 2 should not be as good as No. 3. Why, then, is there this wikle variation? Can we do anything to bring Nos. 1 and 2 up to the stamiard set by No. 3". We can. The diflerence in yield of these three ears 
was not due to differences in soil, climate or cultivation. The difference lay behind all this-it lay in the character of the parents planted. If we could locate all the stalks in the field which spring from the brothers of the kernel that produced No. 2 we would find that the great majority of them were ears, on an average, as good as it is. The same thing would hold true in the case of the parents of No. 1 and No. 3. This would lead us to the conclusion that the difference in these three ears is due to the difference in the producing power of their parents.

In our study of individual ears we saw the wide variation in the yield which different ears produced. We saw that while one ear yielded 90 bushels per acre, another ear beside it, which had exactly the same conditions, produced only 36 bushels. Some ears produced twelve times as many barren stalks as others and the same held true with the broken stalks. Now if we can select the ear which gives the large ear-proclucing stalks and leave out the one which produces the small ear and the one which produces the nubbins, we will have gone a long way toward materially increasing our yield for it is evident that this wide variation is due to the difference in the producing power of these two ears. In this work of selection the ear may be taken as the unit. While there is something in the individuality of each kernel, we are sure of getting good corn and a large increase in the number of good ears to the hill if we study our seed ears carefully and plant only the best. Fourteen ears on an average will plant an acre, therefore, if we put in one ear that produces a great many nubbins and barren stalks we greatly reduce our yield on that acre.

\section{Don't Get the Cultivator Too Deep}

T.he ground finely cultivated before the corn is planted will leave it in such condition that you may at the first plowing before the corn roots have spread out plow as deep as you wish to, as to fully kill and cover all weeds

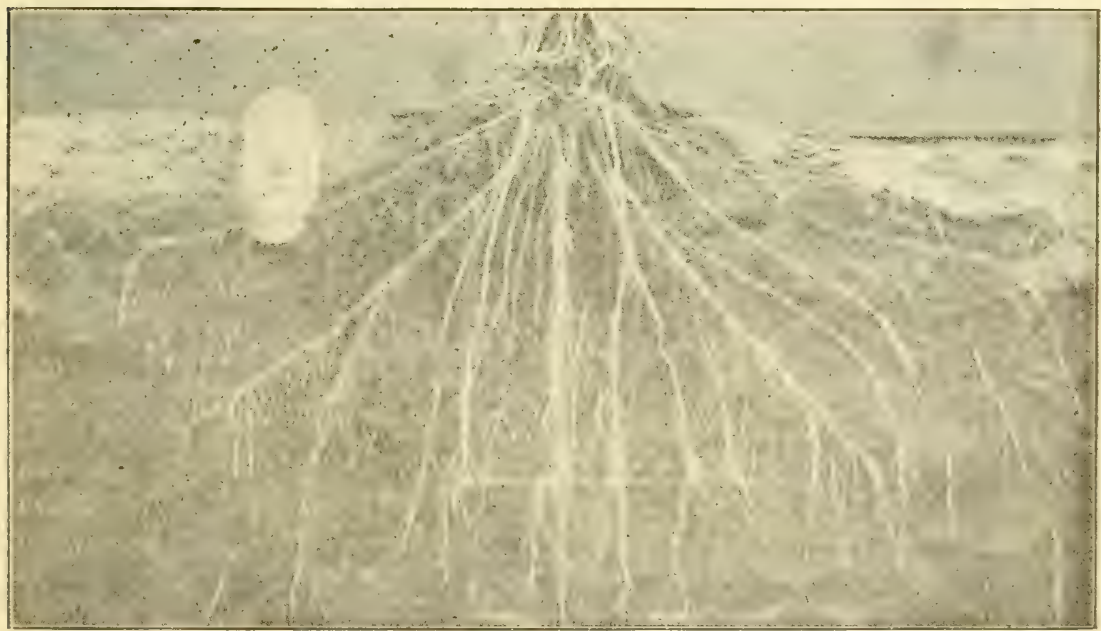

after which the cultivator must be run more shallow but never deep enough to interfere with the root system. 
Why deey enough to kill the weeds? Simply because you are trying to grow grass or weeds in the same field. We sometimes think that weeds actually poison the ground but whether or not, they take the strength of the land which should go to the corn, they rob the corn of its moisture, and hence they should not be tolerated.

Have you ever seen a cornfield in which weeds had come up after planting till they threatened to take the crop, and the farmer had gone through and tried to hoe them out and then got tired and quit? If you ever see that (and you may see it every year) just notice, please, the difference between the corn out of which the weeds have been cut or pulled, and the corn where they have been allowed to grow. Corn and weeds cannot live together in the same house.

Why not plow deep? Simply because by the time the corn is knee high the roots reacb from row to row and come up just as near the surface as they can get moisture. See cut: the top of the ford shows top of the soil. Why should you cut off these roots-why limit the pasture field of the corn plant? The amount of corn that you will get is proportionate root growth. If a man will take a day off and wash out a hill of corn for the purpose of finding out where the roots are, where they are feeding, he will do his corn more good than if he plowed corn that day. It is quite as necessary for the farmer to understand the anatomy of the corn plant as it is for the surgeon to know the bones and veins and arteries and muscles and ligaments and tendons and nerves of the man on whom he proposes to operate.

Another reason why you should not go deeper than necessary to kill the weeds is because you want to leave the space between the rows just as level as possible. You want to use all the field as a pasture for corn roots, and the corn root must have moisture. The more level you have it, the greater proportion of the pasture the corn roots can utilize. They must have moisture, and if the corn is ridged up it has better opportunity to dry out; hence there is less moisture and the roots must go deeper. Don't get the old idea that was prevalent when we were boys that you have to throw the soil up around the corn to keep it from blowing over. Nature has provided means for enabling the corn to stand u ) straight. It has provided an admirable root system for that purpose: thsrefore let nature run that part of the business. It should bə your aim to keep your soil in such shape that the plants will have the greatest spread of 100 is and the greatest supp'y of arailable moisture. Nature will look after the rest.

\section{Deep vs. Shallow Cultivation of Corn}

\section{By James .1thinson, Iss't. in . Agriculture at the Towa Experimental Station, .Ames, Ioura.}

The amount and d stribution of the rainfall throughout the corn belt is just sufficient to carry the corn crop through the average season. Indeed it is the comparatively light rainfall, together with a certain amount of sunshine and a given temperature, that creates thi , the greatest corn belt in the world. It is true that there are exceptional seasons when the rainfall is sufficient to safely mature a crop, and yet, as the science of cultivation becomes more fully understood, the damage to the corn crop on account of a meager supply of moisture is bəcoming very much lessencd. In the past the cultivator has been used largely as a weapon for destroying weeds. When 
its purpose was accomplished in this direction, its duties for the season were at an end.

The modern idea concerning the corn cultivator, or corn plow, as it is mostly called, attributes to the implement a three fold purpose, namely, the conservation of moisture, the destruction of weeds, and the aeration of the soil. Concerning the first factor mentioned, that of conserving moisture, there is no longer any dispute as to the great value of cultivation in this respect. King found a daily loss of more than three tons of water from an acre under cultivation than from the same area uncultivated, which loss was directly due to greater evaporation from the uncultivated soil. This would amount to a two-inch rainfall in the course of two months, quite enough to save a crop in a dry season. However, this great saving of moisture is not accomplished by any fixed number of plowings, as, for example, it is the practice of certain farmers to cultivate only $t$ wice while others practice three plowings. As a matter of fact it is impossible for anyone to say just how frequently corn should be plowed as so much depends upon climatic conditions. Every rainfall prepares the soil in the best possible manner for * the evaporation of moisture by leaving the surface soil filled with small pores, which act as water conductors between the lower soil and the atmosphere. Just as soon as the free water that enters the soil by the force of gravitation is arrested by the capillary forces in the soil it immediately begins to arise toward the surface by virtue of the same force that arrested its downward course. It therefore follows that the breaking up of these surface pores will check this flow of water into the atmosphere, hence the wisdom of making free use of the cultivator after heavy rains.

But there is less controversy over the importance of freouent cultivation than there is on the subject of depth to which corn should be plowed. And right here let it be said that the nature of the soil and the climatic condition are very important factors. Our experiments up to the present time favor shallow culture, that is, a depth of from one and one-half to two and one-half inches, as compared with a depth of four to five inches. In 1899 the yield from the shallow cultivation was seventy-two bushels per acre and from the deep sixty-nine bushels. In 1900 the crop that received shallow cultivation yielded ninety-three bushels per acre, while the deep culture crop yielded eighty-nine bushels. During a period of five years the Illinois Experiment station reports a gain of five bushels per acre from the shallow culture as compared with the deep. While these experiments are decidedly in favor of shallow cultivation, yet they cannot be accepted as applying under all circumstances. But let it first be explained why better returns are obtained from the shallow culture. It has been demonstrated by King that a three-inch mulch will conserve more moisture in a cornfield than one an inch deep, and yet nearly all experiments favor the shallow culture. The explanation of this seemingly contradictcry situation is found in the fact that while the roots of the corn penetrate the soil to a depth of four or five feet, it is, after all the surface roots that are the principal agents through which food elements enter the plant. Not that the lower roots are incapable of taking up plant food if it existed in the lower layers of the soil but that the conditions for the liberation of food elements are only favorable in the surface soil, where there is moisture, warmth and an abundant supply of air. It therefore follows that a crop can ill afford to part with any of its surface roots. I have often heard farmers say that they like to hear the 
cultivator tearing the corn roots, as they believe they are then doing some good. It is true that the plant will tend to develop a stronger system below this line of cultivation, but, as said before, there is but a scant supply of plant food in this lower soil upon which they can feed, their oftice being larkely the taking up of water. In a dry season it is especially injurious to a crop to destroy lyart of its root system, and indeed it is reasonable to suppose that no good will be accomplished by root pruning at any time.

However, there are conditions under which it may be advisable to plow to considerable depth. If a soil contains any considerable amount of clay, and the season would be wet, it may be necessary in order to warm the soil and destroy the weeds to plow or cultivate to considerable depth. On this topic John Cownie says: "In heary soil and wet weather shallow cultivation is a mere waste of time and labor, while deep and thorough stirring of the soil, leaving the surface between the rows somewhat rough, destroys weeds and assists in the evaporation of surplus moisture, and in addition deep cultivation allows the air to permeate the soil, to warm it and assist in forcing

growth. But with light soil and during dry weather, surface cultivation will destroy weeds very effectively, for growth is then slow and greatly retaried and the object should be to conserve moisture, and this is best accomplished by thorough and repeated stirring of the surface soil, leaving it as fine and sanooth as possible."

Shallow cultivation cannot be adopted unless the soil is thoroughly prepared before planting. If planting is done amidst a crop of weeds, these in all probability will be so firmly established as not to be disturbed by the shallow shovel. Under such circumstances it is our piactice to use the deep shovels to destroy the first crop of weeds before the root system of the corn is developed to an extent that will render them liable to injure. Indeed, I would advise the complete destruction of weeds at all hazards, although it is much better to do this when they are young and tender. In crder to cope with a variety of conditions we hare two sets of shovels with every plow, the deep ones to be used during the early part of the season if necessary, and the shallow ones when the rainfall is light and the weeds are well in check.

There is another factor that should receive some attention, that is the leaving of the surface soil as smooth and level as possible after every plowing. A rigid surface exposes more soil to the drying action of the sun than a smooth one, which is another argument in favor of shallow plows, I like the attachment on the Tower cultivator which levels the soil after the knives, leaving it smooth and level. This may seem a small matter, and yet the difference between success and failure in any busine's is often due to the attention paid to details to "small things." JAMES ATKINSÖN, Iowa Experiment Station, Ames, fowa.

The above fully carries out the ideas that for years we have been talking to our farmer friends and practicing on our Pleasant Valley Corn Farm.

J. B. ARMSTRONG.

\section{What May be Done to Increase the Yield of Corn}

\section{GOOD SHAPF OF EARS}

Fig. 16 illustrates good form of ears. All are well proportioned, have good butts and tips, the rows are straight and the kernels uniform. All the ears show strength, constitution and good breeding. Ears 1, 3 and 4, would 
plant well together. Ears:3 and 1 are slightly better in shape than cars : and 4.

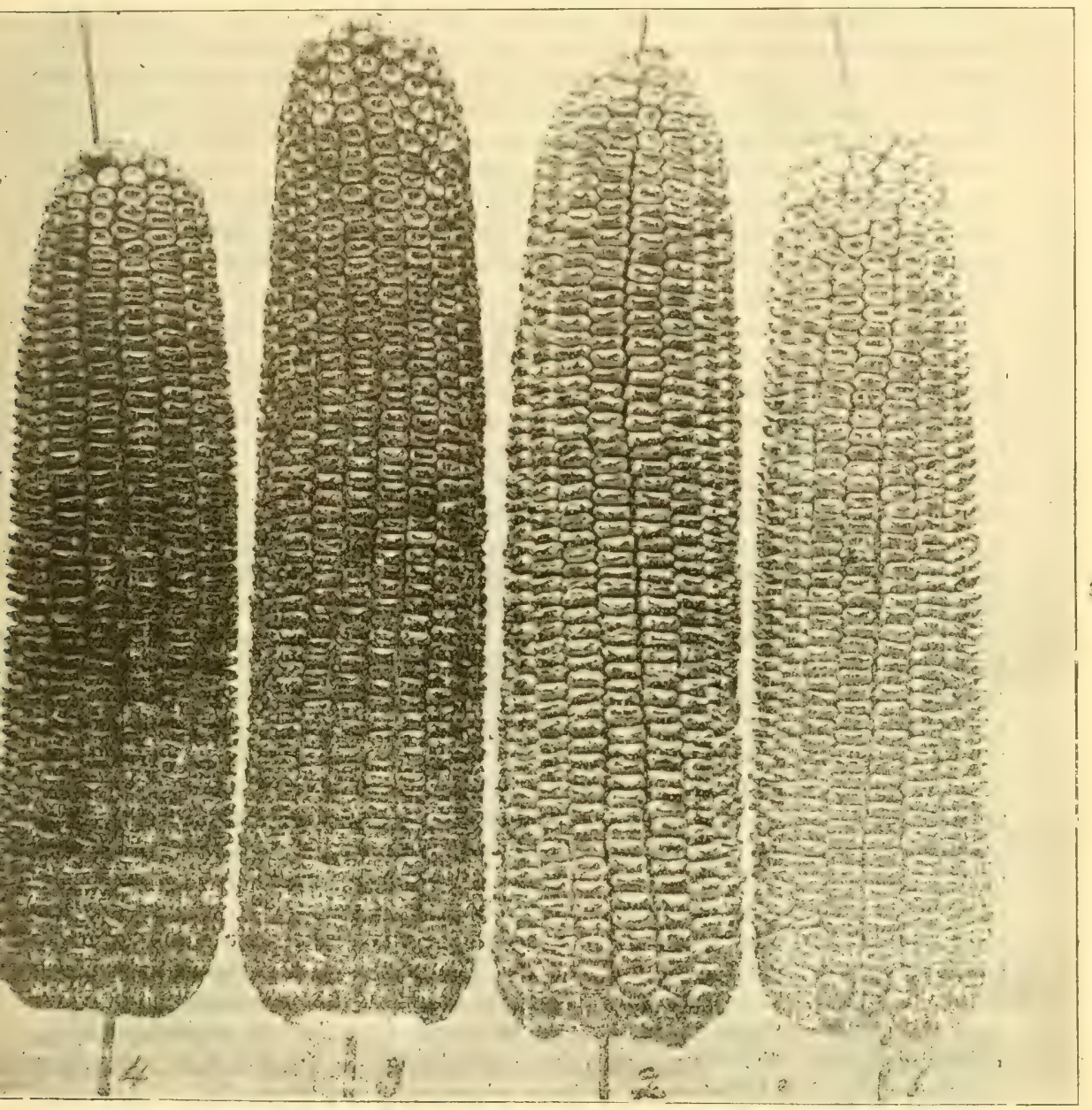

Fig. 16.

When we realize the possibilities that are wrapped up in a single ear of corn and then make the careful selection the importance of the subject demands we can, in a few years, greatly increase the value of the corn crop.

Recently the Journul gave an account of the success of corn breeding in Illinois, Kansas and Iowa. Missouri has done little or nothing in this direction. If we may believe Geo M. Tucker, instructor in soils and crops at the Missouri State University, he notes in a recent bulletin that Illinois has increased the average of her corn crop cluring the past ten years, 2:- per cent. In the same time Indiana has increased her average 12 per cent and. Iowa has brought hers up to 28 per cent, and Kansas and Nebraska 14 to 16 per cent, but Missouri has made but 1 per cent and in all these states the increase is 
due to corn breeding and selection and better attention to cultivation. Here we have before us a striking object lesson of what attention of this sight might do for Missouri. The acreage of corn in Missouri in the last year was $767,645,600$, and increase of one bushel to the acre would mean 7,645,600 more bushels of corn or an increase of over two millions of dollars in value. The state revenue by direct taxation last year was two million six hundred and thirty-two thousand dollars, so an additional bushel of corn to the acre would almost pay the whole direct taxation of the state. "Now" says Mr. Tucker, "if three, four or five bushels could be raised, two millions two hundred and ninety-three thousand, four million flve hundred and eighty-seven thousand or sixty-eight hundred and eighty-one thousand would be clear profit to the farmers of the state and five bushels to the acre would be an increase if all the farmers in Missouri paid attention to their seed."

Improved seed may be obtained if buying it of reliable seed growers. In planting those varieties of corn that have been degenerated by time and are producing $\mathrm{twisted,} \mathrm{spindling,} \mathrm{dwarfed,} \mathrm{abnormally} \mathrm{large} \mathrm{with} \mathrm{little} \mathrm{tendency}$ to produce strung stalk or healthy leaf. The farmer cannot expect to get a large yield of grain from the seed grown upon such field. It will be subject to a similar abnormal growth and a poor development. It is a well established fact that the quantity of the grain depends upon the plant that bears it, and the plant which had fertilized Seed plants should be strong and vigorous, with an erect symetrical and well developed stalk, tapering regularly from the base to the tassel with well developed broad leaves uniformly set upon the stalk, and no appearance of dwarfed or stunted ears at the various nudes but with one or two well developed ears and these born at a medium height above the ground. It is not adisible to select seed corn from large or abnormal plants, nor select large abnormally ears to plant. The result of that kind of selection will be to develop a tendency to produce plants that the soil will not be strong enough to bring to maturity and the grain must suffer in consequence. In a field or breeding plot there are always abnormally small and abnormally large plants but the actual adaption of the soil is measured by the average and not by the extremes. When everything had been done to secure a perfect stand there may yet be a relatively small number of ears in the field on account of the barren stalks. Many stalks that came from the best selected kernels may not bear ears. Therefore, it'is necessary in order to secure a large yield to detassel the barren stalks in the breeding field in order that they may not pass their barrenuess along through the ears which their pollen reaches. The farmer who desires to breed up his own seed must have a breeding field at some distance from his other corn if possible. This field must be kept in a good state of cultivation, the barren stalks must be detasseled as soon as their tassels appear and further selection may be advanced by detasseling others than barren stalks if they are not considered suitable. Then when the crop is made there should be a selection of seed ears by measurement, weight, etc., not only with the eye to the ears themselves but also the plants which produce them. Then by selecting the best kernels from the best ears for use in the breeding field another year, the farmer can soon breed up a corn perfectly adapted to his surroundings.

It used to be the idea and is often carried today, in selecting seed corn, that a big ear with large kernels was the nearest to perfection, but a great variety of tests made by our best thinking corn growers have proven to me conclusively that big ears may be least desirable. Seed of a variety which 
have been grown on a rich soil for a number of years have acquired the habit of using large quantities of plant food and developing large plants and large ears out of this food. Now it is evident that if seed of this description is planted on thin soil, it will exhaust the food supply in its effort to build a larger plant for the larger ear which it is in the habit of growing and the result is, a crop giving a large yield of fodder and a small amount of grain. The reverse is also true and seed from thin soil will reach the capacity of its growth long before it has exhausted the soil and the result will be a smaller yield than the soil is capable of producing. It should therefore be the object of each farmer knowing as he ought to, his farm soll, and possibilities to select such seed as may be adapted to it, and make his selection according. I find many farmers who are growing on the same farm several varieties of corn; this is all wrong as when this is done the corn will become mixed and while the first year they may do fairly well this second planting will usually be a sickly failure. Get first, what seems to you best, give it the best of cultivation and attention. Secure with care your seed and you will surely do yourself good and by thus doing raise the standard of yield from year to year.

\section{The Possibilities of Selection and Association}

The following cut fully shows to what extent selection and cultivation can do for our corn crop. Several years ago the writer found a stalk of corn which attracted his attention by the strong growth of stalk and leaf on which there were five medium ears of corn;from this stalk the best ear was selected for an experiment for the following year, at which time this corn so selected was planted in a small plat from which the stalk and tassel, which we show you in above cut, was grown with two strong heavy ears, also shown in cut, the strangest part of all. Upon this one stalk was the tassel, wnich you will note by the cut, is very different from the ordinary tassel.

It had one hundred fully formed ears of corn, the husks were perfect in shape as was the the cob which was tully covered with minature kernels, even the silks being present, all, of course, of minature size. Had this stalk of corn been grown in some section where the frost had not killed it so early we would have had a better illustration of what nature may do with corn when the right selection is made. Many will say tbis is only a corn freak; it may be so, yet there were several other stalks in the same plat that bore the same minature ears upon the tassels fully covered with husk.

From this we have a fair hint of what may be possible for man to occomplish with corn. Did it ever occur to you how closely the life and a prosperity of corn is bound up and connected with man. And were man with his thoughts and mind to be wiped from the earth and all conditions for growing corn were left as now, corn could not survive him more than one year. Other grains, grasses, fruits and vegetable would survive, not so with King corn.

Man by his magic touch has so transformed him that the human family must be his associates and the finer and wore prolific will be the varieties of corn. It is but a few years, in fact, not further back than many that read this article will remember, that the only corn had or being cultivated was the little nubbiny, spotted, squaw, eight rowed corn.

But a few years since the man of thought began to study the possibilities of improvement along this line may we then not look forward with great confidence to a greater and grander improvement that will surely come within the life time of the working, thinking, educated farmer of today. 
We find that in the study of corn growing and the more intense farming that the student who had once started on this subject never finds the place at which to stop, but euls his time only as the stalk of corn: when its work is

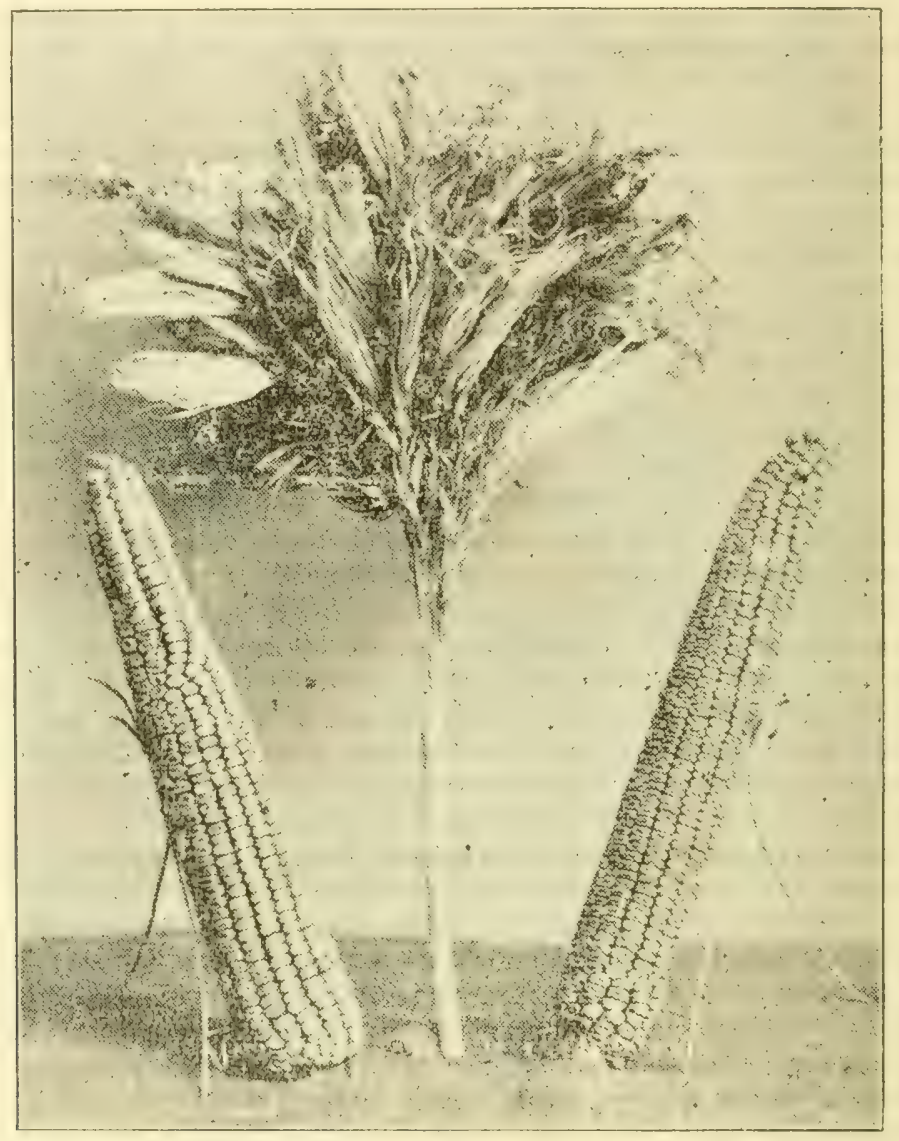

finished the harvest is at hand, the frost has come, then he most happily passes from earth.

\section{Laying Corn By}

Some of the farmers in the corn-belt are beginning to appreciate the fact that the olu idea of "laying the corn by" in early July and permitting it to battle with the elements and work its own way to maturity without further pursuing or assistance is a grave error. The past few seasons have many illustrations of the value of latter cultivation which will be apparent. It is not a question as to whether you should concede the correctness of some other fellow's theory, but purely a business proposition. Will you leave the field to take its chances or will you give it further protection, to the exent of possibly 20 to 40 cents worth of labor per acre, with a possible gain of not only 10 to 20 bushels per acre, but of $a$ "wuch béttér quality? No matter 
whether you wish to sell the corn or feed it, a perfectly matured crop is worth much more per bushel.

With the unusual rainfall that we have had in May, June and early July, and continued cool weather, we are quite likely to get hot, dry weather in in the latter part of July and August. Damage is sure to come from two sources should this prove true to any great extent-first, loss of moisture by evaporation; second, the crusting of the surface or crusting beneath the mulch, and shutting the air out of the soil, both of which can be prerented by additional and later cultivation of the right kind, and especially is this true and very important if a fairly heavy rain should come after your last cultivation.

At this writing, now past the middle of July, our soils are full of moisture, and the corn crop in a very healthy and rapidly growing condition. If this moisture is conserved, and the surface of the moist soil kept from crusting, an enormous crop of choice, well matured corn may be garnered. True, the cultivation must now be done with a one-horse cultivator, and the driver must walk behind it; this, to most farmers, looks like a slow and expensive job; but stop-don't consider the pari of labor and expense without considering the possible returns.

\section{SOME MARVELOUS RETURNS}

Mr. Arnold Martean of Pawnee county, Nebraska, raised 84 busbels of fine, well finished corn per acre in 1893, while his neighbors got from 15 to 30 bushels of low grade corn, due to the fact that they laid their corn by and left it to work out its own salvation while Mr. Martean put forth a little effort and saved fully 50 bushels of corn per acre that was lost to them.

Another man in Franklin county, Nebraska, in 1902, raised over 60 bushels of choice corn per acre by going over his corn two times after his neighbors had laid their corn by. From this neglect they only got from 15 to 20 bushels of very light, chaffy corn.

Another very remarkable case was the result of an unintentional cultivation after a heavy rain in 1901 . This was the year of extreme heat for a period of more than two months. In Fillmore county, on the 7 th of July, covering a small district of country they had nearly four inches of rain. The man referred to was about half through cultiváting his corn, preparatory to laying it by, when this rain came, and as soon as the ground was sufficiently dry he cultivated the balance of the field. Whën harvest tifne came he was surprised to find that he had from 15 to 18 bushels more corn per acre on the land cultivated after the rain than from the part cultivated before the rain. We could quote many similar results, but this is enough to contince anyone that there is much to be looked for from the right time, and the right kind of cultivation.

SOME REASONS, WHY,

We fully appreciate the fact that it . ks not sufheient that a man should know what to do, but he should know why hexdoes it...

Air and water are two principal elements necessary for healthy and prolific plant growth and development. Now with the ground so full of moisture and corn in a very fine, healthy condition, it tands every man in hand to see that he does all he can to reach the highest possible yield. When we come to realize that with a firm surface, as left after a rain, that as high an one and a half quarts of water will be lifted to the surface by capiflary attraction 
and lost by evaporation from a square foot of soil in a single day, and even as high as two quarts during such conditions with kigh wind and high temperature such as prevailed generally in July, we are then in position to seek the remedy. When we come to realize that with the soil loosened and made fairly fine, to a depth of three inches, would lose but a very small per cent of this amount, and but very little would get away, why should we not try at least a small piece for comparison? The experiment will be very valuable in two ways-first, it will add busbels to your corn crop; second, it will prove the correctness of this principle.

REGULATE THE AIR

Air in the soil is a very important element; shut it out to some degree and you will see the plant begin at once to turn yellow and cease, to a great cicmee, to grow, no matter how abundant the moisture may be.

One of the most marked illustrations of this fact was taught out on the Burlington model farm in 1903. For several previous years this land had be en put to small grain by simply disking. The fire guards had been plowed parallel with the railroad, which ran angling through the field. This ground was :lowed in the spring of 1903 fully six inches deep, packed and harrowed and sowed to oats; as the work was pretty thoroughly done the field looked to be level. When the oats were about six inches high there was a sudden and heavy rain of about two inches, which resulted in settling the surface very firm. As soon as the surface was ary enough to permit, we harrowed the field with a combined weeder and harrow. Then followed eleven days of hot, dry weather, at the end of which we chanced to notice a peculiar and very interesting condition. Running parallel with the road were streaks of light green colored oats, and darker green color. Close investigation showed that the light green streaks were the result of the open furrows, left by plowing the fire guards. The rdin had settled the field so there was a slight depression, and in harrowing the field the teeth passed over, leaving a packed, crusted surface, which had shut out the air; the leaves were narrower, shorter stalks and lighter color, while the back furrow was higher and the harrow teeth had cut deeper, loosening the soil more fully.

There was a narrow strip of oats, with taller coarser stalk, wider and longer leaf, and a darker color. To nothing can we attribute this except the increase of air in the soil where the harrow cut deepest and a decrease where the surface was not loosened. We have noted several similar conditions with corresponding results, all of which point to the importance and value of watching and habdling the soil in your cornfields until the corn is made.

Never use the expression again-that of "laying the corn by." It's a bad idea to get into the minds oi the corn growers that the growing corn cropcan be advantaged by stopping its cultivation, and this when it gets shoulder high or thereabouts.

Let the thinking farmer next year test this matter fully by selecting an acre or more, at the time he lays by his field, put a one-horse cultivator into it, keep it going until the corn is glased, and note the increase. He will find that in that cultivation he made his easiest money.-Nebraska Farmer.

\section{The Harrow in the Cornfleld.}

So much has been said in recent years in the agricultural press on the above topic that it is difficult to add anything ner. On account of the differ- 
ent circumstances and conditions, it is impossible to lay down any one rule by which the farmer can safely be guided in the use of the harrow. His own past experience, if he has had any in this direction, will probably be his safest guide. Nevertheless it is worth while to point out the objects which the farmer may have in view, or rather the condition in the corn field which he should desire, and which are essential to his greatest success, and then he can determine whether these conditions can be better secured by the use of the harrow or by some other implement.

A good seed bed having been prepared and planted in due time with good seed, what next does the farmer desire? He wishes the corn to have the free use of every square inch of that field; he wishes freedom from weeds; he wishes to utilize the moisture held in reserve in the subsoil for the best possible growth of the crop for the next ninety days. How can he best gain these three points, each of which is essential to the growth of a first class crop of corn?

What may happen to prevent it? Several things. A soaking rain may happen followed by a hot sun. This will not interfere very much with the growth of the weeds, but on heary lands it may form a crust and prevent the more tender corn from pushing itself into the sunlight. If there is nothing done, the weeds may attain such a hold that it may not be easy to eradicate them by surface culture, and with anything else than shallow culture he may not be able to secure the mulch of dry dirt so essential to the utilizing in the most complete way of the stored water.

In view of these contingencies, which are very likely to occur, our preference would be to immediately follow the corn planter with a shovel plow cultivator, or disc, and give very deep cultivation before the corn appears, running as close as possible to the drill or planter marks without disturbing the corn and thus bury what weeds have already sprouted and securing deep cultivation at the start. We would then foliow with the harrow and harrow right along, first crosswise until the corn was up and keep on harrowing so long as the ground was in fine condition and no damage was done to the young plants, using of course, a light slanting toothed harrow. It is not necessary to say that we would under no condition use the harrow on very wet land for the reason that it would not kill the weeds nor would it hetter th ? condition of the land; neither would it promote mulcb. We would wait until the ground was àrying ofi, then would not harrow late in the evening for the rcason that there would not be enough sun heat to kill the weeds; nor would we care to harrow on a cloudy day.

Just how long the harrow can be used depends on circumstances. When the corn is a couple of inches high, it is not advisable to harrow very early in the morning as there is more breakagre befo:e th sun $t$ ughens the leaves and blades. When the conditions are all right, the sun warm and 1 he ground dry, one may apparently do a great deal of damage with the harrow and yet at the same time do the corn sreat benefit. The beauty of harrowing is that it enables you to get close to the stalks, even raking through the hills if the harrow be light enough an: slanting toothed, thus thoroughly breaking up the crust and at the same ime killing all the weeds.

Inder conditions where it is possible to use the harrow thus effectively, corn needs but comparatively little work afterwards, providing it has bad deep cultivation between the rows to begin with. About all that is necessary afterwards is to create the dust mulch in order to conserve moisture, and this 
cannot be done without killing the weeds. Shallow cultivation without any kind of implement then becomes practicable. If the weeds are allowed to become deep rooted, the deep cultivation must be adopted, and this necessarily involves root pruning which, however, is not arlvisal)le in the Mississippi Valley.

Once more we cali the attention of our readers to the fact that a dust mulch of two or three iaches shuts ofl to a great extent the evaporation of the water and utilizes the main bulk of the stored water in growing a crop of corn. This must be done if we are to get the very best results. It is not possible for any man to grow a good crop of corn with the average rainfall, alone, of the Nississippi Valley. A good crop can be grown only by using the water stored in the subsoil and to utilize this we must have resource to the mulch of dry dirt formed wherever you have surface cultivation following a well prepared seed bed and deep cultivation before the corn is up. Keeping these points in mind, which need only be stated to win the approval of every reader, the farmer can determine fur himself when to use the harrow and when to let it alone.

\section{Our Method of Corn Cultivation.}

We are receiving communications very often asking many questions in regard to our views on all subjects pertaining to corn growing. Our manner of planting and cultivation, the different tools we use upon our farm, the number of times that we cultivate our corn and what time it is best to lay our corn by, etc. In a former communication we bave given answer in a general way to many of these questions but just now in our latitude the planting of corn is the one which is the thought of our farmer friends and is foremost in their mind. We will give you what seems best to us on our seed corn growing farm. I wish if it were possible that our ground might have been fall p!owed. The ground has been left as rough as possible. At springtime it would have been so thoroughly frozen up that many of the worms and insect would have perished and the soil wou'd have been given new life for the coming year but if we are to plant upon ground not fall plowed we would start the stalk cutter as soon as the stalks are fully dried and do the best job possible and follow this with the stalk rake burning at once all such trash as we may gather. This we would follow as soon as convenient with the disc as this will so fix the ground that most of the weed seeds still left will very soon germinate and grow: then comes the best opportunity that you will have at any time for killing the great crop of weeds which are sure to spring up. This may be done with the drag, the weeder or any other light cultivator. () ur next operation is to start the lister making our rows as straight as possible having it deep into the ground but not planting the corn. This we would follow with a high wheeled corn planter; dropping the corn if possible to the arerage of three in a hiil on high ground, four on rich land, using the check row.

In this manner of planting you derive the advantage of both methods of planting. to-wit: the planter, the check row and the lister system and by this method your corn is in the ground in shape that it may be easily tended in both airections. Our first cultivation would be with the two-rowed cultivator following in the lister rows as with listed corn filling in the rows of corn covering the roots over far down in the ground and giving the stalks better 
protection from being hurt by the root louse or the wire worm and of the advantage of cultivating both ways. After making two plowings with the double-rowed disk cultivator we turn and cross this with the largle ('law which leares the ground smooth and level. For ten years this has heen our method of cultivating and it has done us good. I have stated in a former communication that I have two sets of implements which I use, the tworowed cultivator being the first and the Eagle Claw the second, although any of the small shovel cultivators may do as well. We find that when our ground is leveled up we may use the weeder with great success as one horse and man will be able to go over at least 20 acres per day. This leaves the ground in fine shape. Our custom is to keep this cultivation up with the Vagle Claw and weeder as long as we can work the corn witout injury. Do not quit because your neighbors do or because the 4 th of July has arrived, as each plowing after these dates bring you many bushels of finely matured corn. Do not forget that eternal vigilence and intelligence and hard work makes a bountiful crop. Among the very best surface cultivator is the Eagle c'law. This is one of the first gotten our for this worn and has always kept at the head of the procession. I have two different makes of weeders, both good. One thing I wish to say to all interested, don't be in a hurry as to planting your corn. You can do better work for your crop by thoroughly pulverizing the soil and getting your seed bed in such shape that when you do plant there wili, if the weather be favorable, be nothing to stop the germination or growth of your corn.

\section{Corn Breeding Or Selection.}

Twenty-five years ago we started the study of corn with the view of the possibility of getting a larger ear, strogger stalk, a greater amount of foliage, a more prolific bearer and a greater amount of ieeding value and today looking back over those years of study and experiment we can hardly realize the great progress we have made in this direction. Our first venture along this line being with corn grown in central Illinois and taken to northern Michigan. The wonderful growth of the foliage, stalk and corn was the talk of those who saw it, and was convincing proof to me that there was a great possibility along this line brought out by this little experiment. Our study years ago, as many of the readers of this paper will remember gave our efforts and the Farly Yellow Rose, corn much notoriety but such things only promptcd us to greater efforts until our corn was given first place at the Experimental and Testing Siation at Ames, Iowa, and when we were informed by letter from Secretary Wilson t.en in charge of the Agricultural Station that our corn had made the wonderful yield of 10 bushels per acre and had shelled ti2! poundis from 70 pounds of ears wh ch beat all competitors we realized as never before that our eflorts were not in vain and that we were on the right track. that in fact we were doing the world and the farmers grood although our enthusiasm was sightly chilled when we in our honest way showed the letter to a farmer friend he very cooly asked what we paid for such a recommendation, and well do I remember the answer given to him at that time. "There are some things that can be bought but no such letter of recommendation could be bought from Secretary Wilson who wrote the letter." Soon after this one of the most progressive farmers who had bought his seed from me and who had grown a wonderful fine crop of one hundred acres or more said he was feeding several car loads of cattle and weighing them every week so 
as to know just the amount of grain they were making from each bushel of corn and he found that when he stopped feeding our variety of corn and commenced feeding corn bought promiscuously from the surrounding farmers his cattle lost fully twenty-five per cent of the gain that they were making when feeding upon our corn. This was positive proof to me that our corn which had been awarded 7 pounds more weight of shelled corn per bushel than other varieties was the corn that would lead the world. We were not theorists, no scientists, but were working on honest undisputed proof from facts. Soon the Experimental and Testing Stations commenced work along the line that we had been following for years. The subject of selecting and improving corn with a view to securing the largest amount of gain has begun to take hold of the mind of the farmer only in the last year or two. In two or three years more farmers will all be thinking on the subject and then we may expect progress at a very rapid rate. When a country is new and the mind of the farmer is intent on paying for his farm and erecting suitable buildings, cattle are just cattle, hogs are just hogs and corn is simply corn. But when the stock breeding has been established on a firm basis, we begin to have improved cattle, improved hogs, improved sheep, and improved corn.

The farmer begins to realize that there is corn and corn and that some seed corn is worth a great deal more than others in the same way that he has realized that there are cattle and cattle and some breeding cattle are worth many times as much as others.

The object in breeding corn, is to secure a type of stalk and ear suitable to the district in which it is grown. Similarly the object of the farmer in breeding cattle is to secure a type adapted to his environment and to the market. Why grow eight rowed corn such as the Indians grew on a farm that will grow twelve, fourteen or sixteen? Why grow this last on farms that will grow eighteen, twenty or twenty-four? Why grow an ear eight inches long when the land will produce a ten inch ear or even better"?

There are many things involved in the breeding of corn besides the shape, the circumference and the length of the ear. Why grow corn that has 30 per cent of barcen stalks when by careful breeding a variety can be developed that bas ten per cent, five per cent or even less? The bre ding of corn inrolves a careful study of this question: what is t e cause of barren stalks? It is too thick plantiug or some injury to the stalk or unfavorab'e conditions under which the ear cannot develop? Or it is in addition to this a particular kind of corn mixed with the seed which under no ci cumstances weuld produce an ear tut the pollen of which fallin? upon fertile stalks will produce grain which under no circums ances would proluce a bearing stalk in the future? We do not regard this point as altogether settle 1 hut it is worthy of the most careful study. It is a fact that the original of the corn was earless and produced grain on the tassel as it sometimes does now on suckers but in a long slow process of evolution and not yet en:irely completed, a barren stalk is the result.

That we have for years been trying to solve by cutting out all barren stalks and planting only such corn as is produced by strong healthy stalks and baring fully matured ears that are tinely covered at both butt and tip which produces a variety which under proper cultivation produces an ear or more for every stalk.

All hreeding whether of cattle or corn, must take into consideration the enviromment. Hence corn breeding is most intimately connected with corn 
growing. There can be no successfui breeding without the very best kinci of culture as there can be no successful breeding of live stalk without the most careful breeding. The most highly bred corn if poorly cultivated in a had season will produce inferior corn, the merit of it however, being that it will do better under unfavorable circumstances than corn not properly brec. In fact, the breeding of corn or any other grain must proceed aloner the lines already well established in live stock breeding, and the same mistakes nill occur.

Any number of farmers will be taken with the cross craze in corn breeding just as they liave been with live stock breeding and will motet with the same disappointments. Other men will think that everything is in the meed and neglect the cultivation. Still others will not take adrantige o mucd-

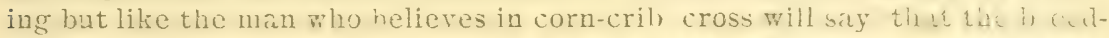
ing goes in at the month and that rich land makes big corn me dator wiat kind is planted.

Nevertheless the breeding of seed corn will proceed. The subject has taken full posession of the best informed ant thinking wen atous wir., lite and the farmer who buys his seed corn has learned the fact that the intelligent, thinking man, who is making corn his life study will be more apt to bring out and place before the people not only corn that will grow, it will combine length of kernel the per cent of corn as compared to cuh, the recuing quality, the time of maturity, the amount of foliage, the per cent of barren stalks and many other questions that make or mar the desirab.lity of each variety.

\section{Adapting Corn Varieties}

We are always learning something new about the corn plant. ()ne thing, new at least to a good many students of the corn plant, is that corn varieties differ so greatly in their characteristics that success or failure with corn depends on the selection of the right varieties for certain fields. It is not unusual to hear of a man declaring that the variety of corn he grows is one of the most profitable in the world, will give most astonishing yi: lis. The fict is that he is growing it on a location that is admirably suited to it. We are now coming to have varieties of corn adapted to uplancls and to lowlands, to rich land and to poor lacd and it may soon be that we may add tiat variety adapted to the thor ugh worker and the slipshod farmen, but thu- fal t has been fully demonstrated that thuse varieties grown on rich bo:tom lave for a length of time will not do nearly so well when changed to hisher and thinner soil until they have fully adapted th-m-elves to the great chan re so that it is often the case that two fumers in the same neighborhood may buy seed corn from the same grower, one have a fihe crop to matu e early, bearing large, fine, sound, heavy ears," while the neighbors get very unsatisfactory and light chafiy corn, the one says, "my failure is from the fact that my seed was not acclimatea" while the neighbors think the acclimat on was just right but in our judgment the adaptability of the corn was wrong, as one had a hill farm and the other a bottom farm, hence the great difference.

The lowland variety may do very well on the upland in a wet year, but in a dry year proves almost a failure, while the variety adapted to the upland yields well even in bad seasons. At the present time this difierentiation is only brginning to be made. During this summer corn growers would di; well to watch the beharior of corn on lowlands and uplands. At the present time 
we have only very meager data by which to figure out what kind of corn a man should select for the bottom lands and what kind for the uplands. Some of our experimenters are only now just beginning to study the corn plant from this standpoint. We have, however, much to hope for from our agricultural colleges in this matter. The students are taking great interest in such matters and are taking up every phase of corn growing. This study of varieties is one that may well engross the attention of some of the brightest minds.

The above is very good and yet the man who has by association learned the various different varieties of corn is fully aware that the large heavy eared variety, such as require a long season and great quantities of plant food, must necessarily be cut short of the same when put on hilly light soil, while the same land will grow fairly well the smaller and quicker growing varieties.

\section{The Farm Boy Who Aspires to be A Farm Manager}

True leadership is a rare quality. Few men possess it. A successful farm manager is a man who is a leader and organizer of men; a leader of thought along agricultural lines; a leader in accepting and putting into practice new agricultural truths which are almost certain to increase the protits of the farm, writes W. H. Stevenson in Wallace's Farmer. There, fore, the young man who aspires to prepare himself for a farm managerwhether the farm is to be his own or another's, aspires to reach a goal which is worthy of the most earnest eflort, persistent work and years of self-denial, for we believe that his reward will be ample, not only in a financial way, but also in the consciousness of a life well spent amid the surroundings which usually tend to bring to their best development a man's mental, moral and physical qualities.

The farm boy of today who accepts farm management as his chosen line of work, enters a fiela of endeavor which calls for ihe very best there is in him. He cannot afí and acquire scientific knowledge which pertains to the widely diversified facts which will always stand as all important factors in his work.

Valuable experience regrarding many practical subjects can be gained on the farm, where the young man comes face to face with certain problems day by day, but that more fundamental strength which springs from scientific knowleclge can best and most easily be acquired in these latter days in our agricultural colleges. We have ample proof for this statement in the splendid records made by young men in all parts of our country. Almost without exception, where we find an agricultural college graduate in a farming community there we find a man who is doing something of real merit not only to better his own condition, but also to lead his neighbors to fuller appreciation of the pressing need for better method; and greater knowledge regarding their farm work. Aud who can measure the value to any community of a leavening element at once so potent and helpful?

The young man who is to take charge of a farm needs this lárger training because a new agriculture is dawning; an agriculture with more numerous and complex problems; an agriculture which demands that hand work must be combined with head work; an agriculture which will not give a bountiful return to the man who knows only how to plow, harrow, reap and sow but an agriculture which will abundantly bless the one who brings to his as- 
sistance every resource of a fertile brain as well as a skilled hand. This is true in part because the virgin fertility which nature so lavisbly bestowed is rapidly showing the effect of a system of husbandry which has been characterized in many instances by reckless expenditure of soil fertility. These soils, though cropped continuously, have not been so exhausted but that intelligent, scientific care will make them profitab'e for ages to come.

But just this one phase of farm management, if carried to a successful issue, will require clear thinking and much study. In addition, diversified crop production, physical soil conditions, and rotation must be studied, and the intelligent and successful management of a herd of improved live stock requires skill of an exceedingly high order. These, in brief, are the conditions which necessitate trained brains and trained hands. Therefore, because there are on the farm so many complex problems for solution-problems which tax every resource of even the best equipped men-how important it is that our young farm manager give his time and strength to lay broad and deep the foundations of his agricultural education.

Grant that the young man has a good general education: that it is his good fortune to have a scientific agricultural training and a goodly fund of practical experience, but if he has these and has not qualities of a business man his most earnest efforts cannot wrest success from the unfavorable conditions which will confront him on every side. Every successful farm manager emphas zes again and again the fact that he really knows the business methods, practices business methods and is business-like. It is the business farmer of today who is able to sort over the scientific and theoretical facts which are given to the world-pick out the practical and valuable and apply them in a business-like way to the business of farming. The successful farmer of today is a business man because the conditions of his work make it absolutely neces-ary; he is a farmer because he chooses to be. He is successful in proportion as he brings business methods to bear upon his every transaction. Recall, if you can, a present day successful farm manager upon his forty acres or upon a priucely estate who is not a business man.

This fact did not carry in many sectious the same weight more than half a century ago; then the farmer accumulated money and added to his acres year after year more because of favorable circumstances than because of any particular business ability which he possessed. Then vague business methods were in vogue amung the early settlers in many sections: little money was in circulation and barter was the principal means of exchange. In those days the wants of a farmer's family were few-the means for meeting them perhaps were even fewer. But today things are changed, the farmer and his family live in a luxurious age, and luxury, we must remember, always costs money. Therefore, if the farm manager is to meet the larger demands made upon the land for increased profits be must depend for success upon the practice of methods which have made the great commercial enterprises of the country successful. Certainly broad-gauged comprehensive business methods were the underlying factors which made for the success of these enterprises.

The farm manager needs a liberal scientific education, business training and ability. Does be not also need in a full measure that peculiar gift which we sometimes call good judgment? It is a characteristic not easy to describe, and yet bow important it is; for good common sense, and good judgment in applying it to the many and varied operations on the farm often 
measure a man's true worth as a farm manager. The young man who is striving to fit himself for this work should ever be on the lookout to strengthen his good judgment. It is a rare possession. It is secured and strengthened by the exercise of the faculties of good common senve, observation, tact and experierce. It cannot be obtained dishonestly; it will not be used injudiciously. cood judgment wiln aid the farm manager to systematize his work. System above all things must be the way to success $(n$ the farm. It is the secret of great husiness success. In ryy few lines of business, however, are there as many disturbing elements which interfere with nicely laid plans as in farming operaticns. The manager may pl n the work with consummate skill but at mospler ic changes ard the pressicg demands of various crops at the same time often bring cowfusicn and disorder to even the mo:t carefully regulated establishment. Therefore, to mret these emrrencies, the manager must do consid rable thinking and vise planning, and just here is where his groch jucgment will scre kimwell, for all too oiten conditicns are such as to compel him to cut loose from precelent and srope along into new and untricd ways. The way must be Iugged atd a!most blocked at times with un-

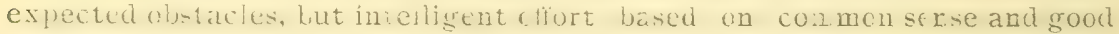
judgment is a powerful lever with which to remove these hindrances. He who wisely uses this lever leads his own business on to victory and success.

(hur sicce:sul farm manager will master bookkteping. The business on a majority of farms consists of several departments The business man makes use of hisset of bouks in many ways, but in none so much as to learn just what departments of bis business are making or losing money. Is it not essential that the famer (i) the same thing? Bookkeeping is a lighthouse to the busiress man: it will as unfailing guice the farmer past many a shoal and breaker a ad of $t \in \mathrm{n}$ enable him to reach a harbor of safety which might otherwise be unknown to him. A simple system oi bookkeeping not only will be a source of satisfaction to the farmer but will also prove financially protitable. Wou'd it not be helpful for him to know, as nearly as the actual cost could be approximated, the amount experded in producing a certain fleld of corn, wheat, oats or hay; to know what it cost to raise his calves and yearlings and fit his stock for the markets: just how much it costs to keep his milk cows a year: what his macbinery, help, repairs, incidental expenses, etc, cost. A knowledge of these points will enable bim to really know his own affairs? na be master of them: without this linowledge it is not easy for him to discover the leaks and $\in Y^{\prime}$ n mighty aperturcs through which the floods of hard times, low prices and pooi crops carry the protits and gains.

Again, the yourg man who aspires to be a farm managcr will endeavor to be a cartful man. Care is a mighty safesuard agrinst many a loss, many a catastrophe: carclessue.s is a withe:ing blint that dwarfs and clestroys everything within the range of its influence.

The conclusion of the matter is this: The thoughtful young man on the farm who is planning to make farming his life work will ea nes ly enclearor during his days of preparation to build into his life ard character those elements of strength which will prepare him to met with asisuranee and ability the prob!em and perplexitiss which in the ulmess of time will anfailingly meet him face to face on the farm.-Wallace's Furmer.

\section{What Is The Form?}

The farm is a factory for converting the inert mineral matters of the 
soil and the elements of the air into food products for either man or beast.

The highest type of these factories are those which turn out only the finished product. Why not have all our farm facto:ies of this type? Thy not turn this material into beef, mutton, pork. hutter, exrs, etc.. etc, before they leave the farm where this transformation was begun?

The farmer is the one wbo is most competent to run such a factory. There are no complicated engines necessary, no hired, skilled lahorers or engineers. Instead of this a good sound judgment, a practical man-one who at least enjoys his calling, who knows a good horse, cow, hog or chef p and who enjoy dealing with nature. To such I wish to say: It requires on]y about twelve pounds of feed to make a pound of butter. Why not condense your results into p oducts of this kind and save the freight on all that extra bulk? If the man at the other end of the line can buy your grain and rough feed and make money by the operation after paying all this freight surely the farmers can find still greater profit in feeding these foods where they are grown. Every pound of grain and roughage produced in this middle West should be fed right here where it is grown.

Not only would this practice insure greater immediate return, but it would also insure a continuance of the producing powers of our lands. ()ur section of the country has been especially favored in its natural endowment of soils and climatic conditions, but nevertheless it is only a question of time when wasteful or improper methods will produce the conditions now found in the East, where hu. dreds of farms have bzen abandoned because the occupants could no longer make a living on them. There are a very large number of farms in this section that have had their productive capacity very greatly reduced already.

In days past it was talked that our rich prairies could stand the soil robbing process for any length of time, but many farmers are learning by sad experience that their day of judgment is fast coming and if they are to preserve their beautiful homes and solid bank accounts they must return to the farm the amount of fertilage that rightly belongs to it, or soon the lock will be fastened and the account closed, until such methods are adopted as shall bring to our lands the richness which once was there. And there is no better and quicker way to get the knowledge required than to read some of the best farm papers, using your ow 1 best judgment as to your own farm or factory. But on one point do not forget the best of all kinds of seeds and stock. Give them the care they need in an intelligent way and your bank account will grow and your factory pay forever.

\section{The Farmer Waking Up}

He sees object lessons in the improved crops of his neighbors, in the fine bred horses he is driving as he takes his family to town, before the fine new carriage that he has just got, and he begins to wonder how he can afford so fine a rig. He begins to think and observe and soon concludes there is something worth knowing and doing that he has not yet acquired. We trust that many such will now read the ideas advanced of those who are leaders in this direction, and the readers of reliable farm journals where in their best judgment it would seem possible for them to do. But a few years ago, we knew of a certain young lady who was presented with a fine watch, but to her great mortification and distress it would not run, and on taking it to the jeweler he informed her that it had not been wound and consequently in that condition 
could not run. What was the trouble? Merely this: she bad turned the stem the wrong way, and that was all that was wrong with the beautiful watch, and this is the trouble with a great many things along the agricultural lines, they are not started in the right way and never will go until they are started right. Land will improve itself if left alone, but nature's process is so slow that its owner will never get any good from it. He will have to start it and keep it wound up if it makes him anything. Thousands of men know better than they do simply because they have never been wound up and started. They read with great pleasure the improved methods of doing things, they are wonderfully interested in the fine development of agricultural implements and of science in regard to their business but they get no practical good from them because they never make a start. It is easy to get in the habit of thinking that all these discoveries and methods are for the so called advanced scientific or fancy farmers only. But I assure you they are not; they are for everyone and it is surprising how simple some of them are, how easy it is to get them and how much good they will do after one gets started. The time has now arrived when the common farmer must be what we term up-to-date. In this we mean the one who nas learned to grow such crops and animals as will sell for the highest prices, such as will pay the interest on our hundred dollar land instead of as formerly on ten. This may be done, in fact is being done. New ideas, tools, seeds and methods. The old is past, the new is here, strive to lead the procession and others will follow.

\section{An Article of Great Interest to All}

\section{DOES IT PAY TO SPRAY POTATOES?}

Does it pay to spray potatoes? is the question which is asked by growers of that universal vegetable, and as for a vast majority of them the question remains unanswered, while each season the problem becomes more pressing. The experiment stations of New York and Maine have of late years giyen large attention to this subject, and the answer of both stations to the query is emphatically in the affirmative. The New York station (Geneva) recently has issued a bulletin on the subject, prepared by Profs. Hall, Eustace, Stewart and Sirrine, which is so timely that we make generous extracts from its pages. And for the photograph from which the illustration of the simple but effctive sprayer herewith is produced we acknowledge obligations to Prof. Hall. The illustration shows just how the work is done in the experience conducted on the farm at West Rush and suggests to any "handy" farmer how to make one out of materials at hand or very easy to secure.

The experiments made were taken up as a result of the tremendous losses suffered from the ravages of late blight. A conservative estimate, says the bulletin, places the loss during 1903, in New York state, from preventable diseases at fifty bushels per acre; for in many districts the crop was hardly worth digging, and, so far as known, there were no considerable areas where diseases did not do more or less injury. These figures indicate a loss to the state, largely unnecessary, of nearly $\$ 10,000,000$; for the area devoted to potatoes in recent years has been about 400,000 acres, and the average value of late potatoes at harvesting time this season was about 50 cents a bushel.

Experiments made last year at the station and at Riverhead, Long Island, confirmed the belief held by all students of potato diseases that spray- 
ing with bordeaux mixture will prevent most of this loss: and tests made during the past season at the same places and at six other localities in the state lend most emphatic support to the belief. The potato grower who sprays thoroughly every year insures his crop against serious damage from blight and rot, and in a season when disease is epidemic will make enough profit to repay the cost of treatment for many years. For example, the gain from spraying at Geneva in 1902 was 123 bushels per acre and in 1903, 118 bushels a gain for the two seasons, at the lowest allowable figure, $\$ 1$ a barrel for potatoes, of $\$ 80$. Allowing each application of the spray mixture to cost $\$ 1$ per acre, a very liberal estimate, this profit would allow the station to spray potatoes for thirteen years, making six applications each year, and come out even if no further damage from blight should occur. Is there any potatogrower who believes that thirteen years will elapse before blight again strikes the potato crop of the state?

To meet the objection that the tests made in 1902 on the station grounds were too limited fairly to determine the effectiveness of spraying, arrangements were made with six farmers scattered over the state, who co-operated with the stations in the tests, three near Phelps, from six to eight miles from Geneva, one at Southampton, on Long Island, nne at West Rush in the Genesse valley, south of Rochester, and one at Charlotte, north of Rochester. Each grower was to give the crop only such condilions, culture and care as he would ordinarily; to spray as often as he thought best, using his own mixtures, apparatus and methods, and to keep an itemized account of the ex. pense of spraying. The station merely required that a portion of the field fairly representative of the whole be left unsprayed and the product weighed for comparison with the yield on an adjacent acre of sprayed rows.

On the total area of 6116 acres sprayed in the six experiments in different parts of the state, there was a total increase in yield of 3,746 bushels, or an average of 61.24 busbels per acre. At 50 cents per bushei the increase was worth $\$ 1,873$. Subtracting from this amount the tctal expense of the spraying, $\$ 296.49$, there is a remainder of $\$ 1,576.51$, which is the total net profit. This is at the rate of $\$ 25.77$ per acre.

The authors of the bulletin point out that some farmers report failure and are inclined to condemn the practice of spraying, but they declare that the disappointment is largely due to two preventable sources of failure. First, it is necessary to spray at the right tim. Spraying is a preventive of plant diseases, not a cure; and if treatment be delayed until signs of damage begin to appear but little good will be likely to result. When the leaves begin to turn brown at the edges and curl up, the little plants which grow within the potato leaves and stalks and cause the disease have already become thorough. ly established inside the tissues and are out of reach of any spray mixture. Though the foliage be thoroughly drenched with spray each day after this time, the infected plants are certain to die quickly if weather conditions be right. Spraying to be effective must be done before any signs of disease appear.

Second, it is necessary to spray thoroughly, for unless the entire surface of the foliage be protected by a film of bordeaux mixture, some of the tiny germs (or seeds) of the disease may find a spot on which to germinate and from which to send their little tubes down into the tissues of the host plant. In time of moist warm weather the potato is growing rapidly and new surface is constantly being exposed. 
Mate the imrleaux with good stone lime slacked grarlually by adding just enough water to keep it moist, not to flood it. When slaked, dilute with on:-thind or unc-half the water required hy formula, and add the dissolved copper sulph ste diluted with the rest of the water. The common formula for hratic for potato spraying is il lbs. copper sulphate, 4 lbs. fresh stone lime, and 50 gallons of water,

For poisoning the bugs add to the amount of the mixture you will use in covering rize acie, one pound of paris green or its eyuiralent in white arsenic in the form of arsenite of lime.

This latter material is cheaper and better than paris green. It costs $a b$ ut our-third as much per pound, and is equal in poisoning properties to twic as much varis green. It requires some time and thought to prepare, however. It is male and used as follows: Dissolve one pound of white arsenic and $f$ ui pounds of salsoda (washing soda) in on gallon of water by boiling 15 or 20 minutes. This makes the stock solution, which can be bottled and kept un:il desired fo use. For spraying potatoes add two quarts of the stock solution (one-ha!f pound white arsenic) to the quantity of bordeaux required to cover an acre. This is equivalent to an application of one pound of paris green per acre.

In using the white arsenic stock solution with bordeaux mixture prepared by the potassium ferrocyonide test it is always advisable to add lime a lit.le in exess of the amount required to satisfy the test in order to preven "the possibility of injuring the foliage. In our experience it has not injurte the fo!iare in the least when used with bordeaux. If used in lime the foliage will be injured.

Tis bulletin is of direct alvantage to the potato grower everywhere But ii may be of even larger value in its suggestion ard proof of the elfect. ivene s of spraying in modifying the ravages of plant diseases. How greatly the artion suffers from these causes is indicated by a a report just issued h. t:e de artin 'nt of agriculture on "Plant Diseases in 1903." This shows that many mil ions of dollars were lost to agriculturists and horticulturists in the [n.ted states and the island possessions in 190; by plant diseases and parasit.s. ()ne of the largest items of loss was from potato blight and rot, the ravages of which were particularly severe in New York, Pennaylvania, Onio, Michigan and Wisconsin. The cotton rot in Texas prevailed to a greater ex!ent than for many years before, the loss being estimated at \$2,000,000 . Rice blast has spread rapidly, and in the past six years the loss from this cause has been $\$ 1,000,000$. One comparatively small item in cucumber downy rust, which in the trucking section near Charleston, S. C., alone cost the truck farmers $\$ 100,000$. Tomato blight and tomato rot in Porto Rico caust d the loss of almost the whole of these two crops. The ravages of black rot in the grape were destructive, but the experts are receiving encouragement i. their efiorts to develope a vine that will resist. Of general interest to the South is the rapid spread of the watermelon wilt. In Ottaway county, Ojio, the loss from peach leaf curl was $\$ 50,000$. Under such conditions there can be no doubt that the use of the sprayer must become universal if the American tiller of the soil is to save himself from destruction. The ordinary farmer has but to try any of the recommendations made and he will be so thoroughly convinced of their reliability that he will very surely follow them fully but from such authority and what you will find in the following from 
the Agricultural Bureauat Washington will be fully convincing and if followed make you much money.

\section{Potato Culture.}

\section{INTRODUCTION.}

This bulletin is not intended as a complete treatise on potato culture. The discussion of varieties and manuring has been merely touched upon, the importance and intricacy of these subjects meriting fuller treatment in a separate publication. But special attention has been given to the most profitab'e amount of seed, and as factors in this question the proper distance between seed pieces and other closely related subjects have been briefly treated. Some other cultural questions have also been considered. In regard to funguous diseases the reader is referred to Fdrmer's Bulletin No. 15 of this Department, "Some destructive potato diseases." Methods of combating insect enemies are treated in Farmer's Bulletin No. 1!!, "Important insecticides."

The potato (Solumum Tuberosum) is a native of America,though it is widely known as the Irish potato because of its general use in Ireland Aside from its universal cultivation in gardens it constitutes an important field crop over the greater portion of the country. The value of the annual potato crop of the United States is approximately $\$ 100,000,000$. Yields of $2: 00$ or 300 bushels per acre are frequenclv obtained over large areas, and there are not a few records of more than 500 bushels. These encouraging figures stand in bold relief against those giving the average yield for the Inited States, which is less than 100 bushels per acre.

\section{SOIL AND ROTATION.}

The potato is grown in every State and Territory, and naturally on a great variety of soils. Indeed, it has been grown on nearly every class of soils, but this fact does not minimize the jmportance of selectlng for the potato the find of soil best adapted to it. The ideal soil for this crop sbould be one so light as to offer no great resistance to the enlargement of the tubers, so applied with organic matter as to be rather moist without being wet, and so rich as to furnish an unfailing supply of fertilizing ingredients. A rich, sandy loam abundantly supplied with organic matter and naturally well drained is preferable. Stiffer soils may be rendered suitable for the potato by drainage and by the incorporation of farm manures: or better by plowing under green erops. Very heavy clay should be avoided if the farm contains any lighter soil. Recently cleared ground suits the potato. Sandy soils, if not too subject to drought, may be fitted for this plant by the addition of organic matter. It is claimed that potatoes grown on sandy land are of better quality than those grown on stiffer soil.

The potato requires a rich soil, bat even more important than natural fertility is a proper mechanical condition of the soil. Artificial fertilizers may be substituted in part for natural fertility, but they are effective only when the soil is in such a condition as to furnish a constant supply of water. The potato should have the best soil on the farm, since it is more exacting in this respect than the other staple crops and since the product of an acre is generally of greater value.

The success of the potato is largely dependent on the crops preceding it 
in the rotation. If clover, cowpeas or other leguminous plants are grown just preceding potatoes, its stubble furnishes organic matter and adds to the store of available nitrogen in the soil. Corn after sod frequently precedes potatoes, and this is generally regarded as the best rotation.

Rye is sometimes sown in late summer or fall and plowed under so as to lighten a heavy soil. Buckwheat and other plants have also been used for the same purpose. On light soils and in rather mild climates, crimson clover for green manuring may advantageously take the place of rye where early planting of potatoes is not specially desirable. One year, or at most two years, is as long as a field should be devoted to continuous potato culture, although this crop is sometimes grown for more than two years in succession on the same land. This latter course taxes heavily the fertility of the soil and necessitates liberal manuring; moreover it inv lves considerable risk of injury from funguous diseases, especially from potato scab. A clean crop of potatoes can not, as a rule, be grown on land which in the preceding year produced scabby tubers. The germs ( $f$ the disease once in the soil must be starved out by growing on the infected field other crops, such as grass or grain for several years. In certain localities in the central part of the United States and elsewhere the following three years' rotation has given highly satisfactory results on farms where potatoes are extensively grown: Fall wheat, in which clover is seeded in spring; second year, clover, plowed under in fall or winter; and third year, potatoes. In some localities the uncertainty in obtaining a catch of clover renders this rotation inexpedient.

Detailed directions for the preparation of one class of soils would not apply to others, hence it can only be said that preparation should be deep and thorough, and that unnecessary compacting of the soii shou'd be avoidel. Plowing can scarcely be too deep, provided that much of the subsoil is not brought to the surface; when practicable, the depth should be gradually increased from year to year. Though the tubers are usually formed within (5) inches of the surface of the ground, the roots feed deeper. At the Utah Station a very large proportion of potato roots were found 12 inches below the surface. At the New York State Station potato roots penetrated to a depth of 34 inches. Girard, in France, measured single roots nearly 6 feet long growing on rich soil, deeply prepared. (See fig. 1, p. 7.)

Practical experience, as well as the extent of the distribution of potato roots in the soil, emphasize the importance of deep and thorough preparation of the soil for this crop Whether fall plowing is advisable depends on a variety of local considerations. In general in a mild climate fall plowing of light land exposes it to leaching; on the other hand, fall plowing is sometimes necessary, as, for example, when a field is badly infested with injurious insects.

\section{MANURING.}

The potato requires liberal manuring. Barnyard manure usually affords a large increase in the crop, for not only does it supply nitrogen, phosphoric acid and potash, but it improves the mechanical condition of the soil. However, its direct application to the potato affords conditions favorable to potato diseases, and thus injures the quality of the crop. For this reason the best practice is to apply barnyard manure to corn or grass the year before potatoes are grown. If it is considered necessary to apply it directly to the potato crop it should first be well rotted. 
If for several years before potatoes are planted the land has been properly manured with farm manures, or with green crops plowed under, commercial fertilizers can be advantageously used on most soils. Generally, a complete fertilizer should be used-i. e, one which contains nitrogen, phosphoric acid and potash. The farmer is justified in supplying all three of these fertilizing ingredients, unless by previous tests he has learned that on his soil a certain one of them can be safely omitted.

of nitrogenous fertilizers, one of the best for potatoes is the quick-acting nitrate of soda. Of phosphatic fertilizers, superphosphate is wreferred. Among potash fertilizers the sulphate of potash has been found to afford a better quality of potato than kainit and muriate of potash. Ashes are extensively and effectively used to supply potash to potatoes.

Numerous special potato fertilizers are on the market, their chief peculiarity consisting in a higher percentage of potash than is contained in the ordinary brands of mixed commercial fertilizers. American experiments indicate that a fertilizer mixture for potatoes should contain a high percentage of potash.

Since the proper position of fertilizers with reference to the seed pieces doubtless depends on the character of season, soil, and manure, no general rule can now be given further than to caution the reader against applying the fertilizer in immediate contact with the seed piece.

\section{VARIETIES.}

The following are among the most widely grown varieties: Early, Early Ohio, Early Rose, Beauty of Hebron, and Triumph. . Hedium and late, Burbank, Rural New Yorker No. 2, Empire State, Mammoth Pearl, White Star, and Dakota Red.

These are standard varieties, and though not necessarily the best, they seem to have given general satisfaction.

PLANTING.

GENERAL DIRECTIONS.

The rows should be laid off as close together as practicable without interfering with horse cultivation. Generally the seed pieces should be dropped in furrows made in the level field and not on ridges. However,low ridges are advantageous for an early crop and on poorly drained land. In covering the seed pieces, whether they are planted flat or on ridges, it is well to leave a small, sharp ridge marking the line of the row. In some localities, however, where excessive moisture is not feared the opening furrows are only partially filled after planting, leaving a depression along the row to be filled by the use of the smoothing harrow or other implement. In planting late in the season this course is sometimes advisable.

The pieces may be dropped by hand in the open furrow, or a potato planter may be used, dropping and covering the seed pieces at one operation. There are several potato planters that do very satisfactory work, but their cost restricts their use to those who plant a large acreage in potatoes or to cases where several farmers can use one together. Their more extended use is perhaps desirable, since they save a considerable amount of labor and erable the potato grower to take full advantage of even a brief period of favorable weather at planting time regardless of scarcity of labor.

There is not sufficient evidence now available to determine whether 
there is any dificrence in yield due to the cut surface of the set being placed upward or downward when planted. Probably there is no loss in letting the seed pieces fall as they will from the planter or from the hand:

In the preparation of the ground and in lanting, the earth along the line of the row should be compacted as little as possible consistent with thorough work, and hence the team should be made to walk between the rows whenever pasible instead of aloug the drill. There is a simple potato corerer constructed somewhat like a triangular snowplow, with the wide end forward and a portion of the point or apex cut away so as to leave a narrow opening at the rear. $\therefore$ o special implement, however, is required for this purpose.

TIME OF PLAN'IING

Each community is the best juge of the proper date for planting. Where potatoes are grown for the early market the aim is to plant as early as possible, without subjecting the young plants to severe cold. 'The crop should be planted at such a dat as to bring the stage of growth during which the tubers are rapidly developing at a time when there is ordinarily dry weather

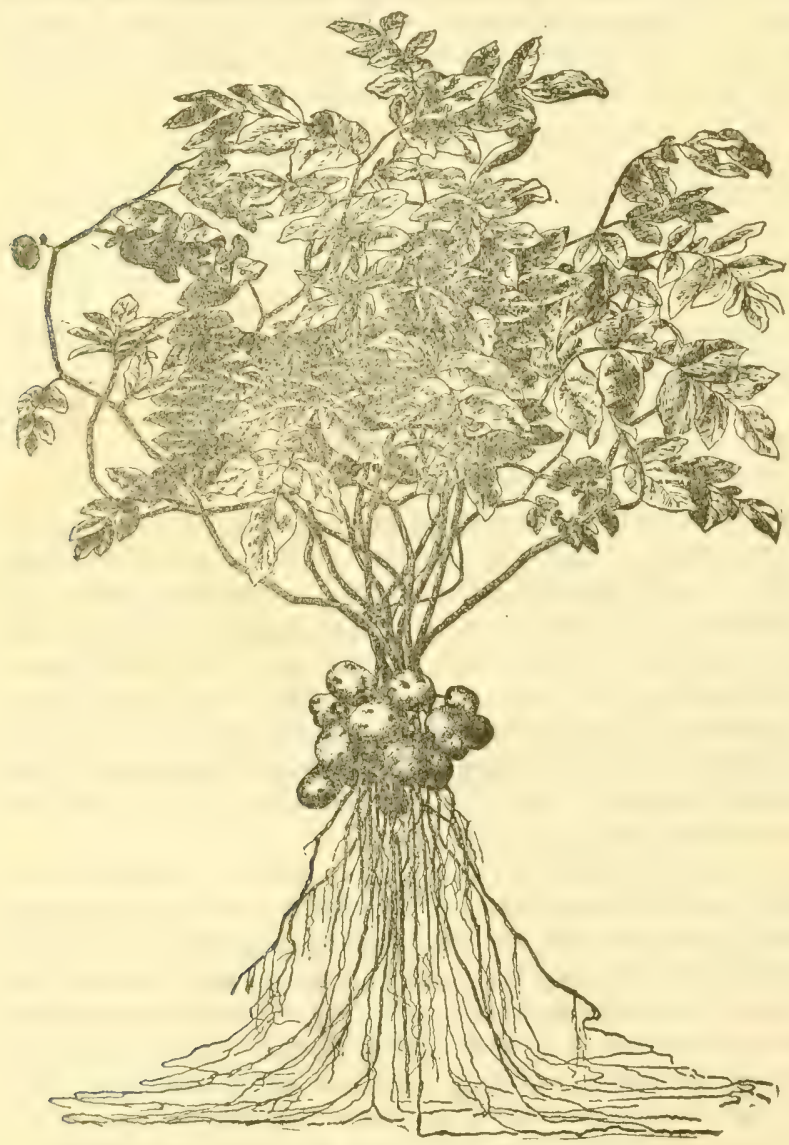

FId. 1.-Entíré plànt, showing root system. is most certain varies with the locality, and each potato grower should so time his planting as to be least affected by drought. Where the growing season is long the crop that is to be stored over winter should be planted very late, so that it may remain in the ground until cool weather. On the other hand, where the season is short, late varieties should be planted in time to ripen before frost.

DEPTH OF PLANTING

The roots of a young potato plant grow, not directly from the seed piece, but from the under. ground joints or nodes of the stem. From these underground nodes also grow the short stems which bear the tub- 
ers at their extremities. (See fig. 1.) Hence the seed pieces should be placed deep enough in the soil to permit several of these joints to form below the surface, so as to aflord room for an ample supply of roots and tuberbearing stems to grow.

Many experiments have been made to ascertain the best depth for planting. The results, with some exceptions, favor planting not less than $t$ inches deep. The favorable effects of deep planting were especially marked on wellprepared, friable soil and in dry seasons.

Very deep planting is open to objection because of the increased labor of harvesting and the langer of a deficient stand when weather conditions are unfarorable. Very sballow planting reduces the yield and injures the yuality of the crop.

To test the eflect on the yield of using seed potatoes from diflerent localities, sereral varieties of potatoes yromn in Vermont and Maryland were planted in both states. The seed grown in Termont wave lavirer yielas both in Vermont and in Maryland than seed grown in Maryland.

It has been found adrantayeous to change seed potatoes erery few years. but from the suall amotint of detinite experimental data now available we believe no linal conclusion can be drawn as to the eflect of the practice. To make the change, tubers of the desired strain may be sent to the grower at a distance, and after two years' cultural under new conditions the stock may be brought back to its original home.

A common practice in the regious where a second crop can be grown on the same land in the same year is to plant in the spring a smali area with Northern seed potatoes, replanting the resultins tubers in Juiy or August, and using the crop produced in the fall for the main spring planting. By this course seed is renewed frequently without sacrificing any of the advantages resulting from the use of second-crop seed stock, such as freedom from sproutling, etc

\section{SEED END V. STEM END}

When potatoes are cut in half through their smaller diameter we hare a seed or bud end more or less crowded with eyes and a stem or butt end on which there are few eyes. (See fig. $\stackrel{2}{-1}$ p. 14.) The experiments to determine the relative value of cuttings from the stem end and from the seed end of tuber have been numerous. The majority of these showed that the yield was greater when the seed end was used. The superior productiveness of the seed end as compared with the stem end was maintained, whether the halves of the potatoes, the thirds, or smaller cuttings were employed

In a few instances, however, the results suggest that the general superiority of the seed end may not be maintained with some varieties and with immature seed tubers.

\section{EFEECT OF SPROUTING}

The growth of sprouis before planting is made at the expense of the tubers from which they draw their support. Hence if these shoots are rubbed oli before planting there is a total loss of the nut:iment contained in them. Moreover, numerous weak shoots grow from the injuredeye. To prevent these evil consequences of premature sprouting, secil potatoes are stored in a dark, dry, cool place. In spite of all precautions the tubers sometimes sprout: but when practicable only potatoes that have not sprouted should be selected for planting. 
If the eyes appear dormant in spring, seed potatoes may be exposed to the light and warmth for a few days before planting so as to promote germination and prompt growth. If long exposed, sprouts will form and careful cutting and planting by hand become necessary, so as to avoid breaking off these sprouts.

\section{QUANTITY OF SEED POTATOES PER ACRE}

A bushel of potatoes (60 pound) may contain 240 quarter-pound tubers. When the seed pieces are planted a foot apart in 3 -foot rows an acre requires 14,520 sets. When tubers averaging 4 ounces are employed an acre requires at these distances 60 bushels for planting whole potatoes, 30 busheis when halves are used, and 15 bushels when quarters are planted. In a number of tests the amount of seed cut to two eyes, spaced 1 by 3 feet, averaged 13 bushels per acre, the usual range being from 10 to 14 bushels. In 18 experi. ments with many varieties the average amount of seed cut to single eyes was at these distances 6.3 bushels per acre, the usual range being from 5 to 7 bushels, though the varieties with large tubers bearing few eyes required considerably more seed.

Results which follow in these pages suggest that it is generally advisable to plant at least 15 to 30 bushels per acre.

\section{SIZE OF SEED PIECES}

In the size of the seed piece planted the practice of different farmers varies widely, some advocating a liberal use of seed and others claiming equally good results from small cuttings. To aid in settling this question the State agricultural experiment stations have numerous tests of seed pieces of different sizes. Taken separately these experi nents show a certain amount of divergence in results, as might naturally be expected of tests conducted under widely different conditions However, the majority of these tests, and especially the figures expressing the average results of all available American experiments, may be sately taken as indications of what the farmer, under ordinary conditions, will generally, but not always obtain.

The effect of size of seed pieces on yield of crop will be treated here under three distinct beads: (1) On the total yield; ( 2 ) on the gross yield of salable potatoes, and (3) on the net yield of sulable potatoes; i e., after deducting the amount of seed planted.

\section{EFFECT ON TOTAL YIELD}

In making up the averages below it was found practicable to use the results of 19 tests of single eyes $r$. 2 eye pieces, 4 tests of 2 -eye cuttings $r$. quarters, 17 comparisons of quarters and halves, and 44 tests of halves $t$. whole potatoes. The results of other experiments less completely reported were used for the purpose of corroboration.

The following table shows the average results of these tests, including potatoes of all sizes:

Acerage differences per acre in total yields from different seed pieces.

\begin{tabular}{|c|c|c|}
\hline & Bushels. & Percent. \\
\hline 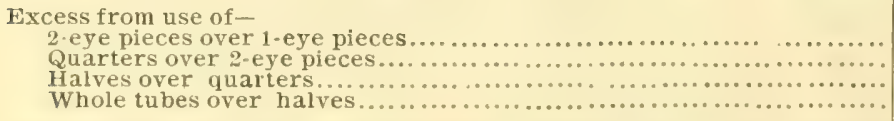 & $\begin{array}{l}26 \\
15 \\
24 \\
31\end{array}$ & $\begin{array}{l}21 \\
16 \\
18 \\
18\end{array}$ \\
\hline
\end{tabular}


If we compare all the total yiclds with the total yicld produced by single eyes we have an increase of 21 per cent for 2 -eye pieces, 41 per cent for quarters, 67 per cent for halves, and 96 per cent for entire tubers. The total yield resulting from planting whole potatoes is practically double that obtained by planting single eyes.

Thus far we have considered only the total yield, i. e., large and small potatoes, and have found that the total yield increases somewhat uniformly as the size of the seed piece is increased. Hence, if it is the aim simply to secure an enormous yield without much regard to expense, in contests for prizes, etc., a lavish use of seed is justifiable. The farmer and gardner, however, have to consider other factors than the total yield, for a heavy crop may consist very largely of tubers too small for the market, or the great expenditures for seed when large pieces are planted may more than counterbalance the increased yield. Before noting the gross and net yields of large or salable tubers, resulting from seeā pieces of different sizes, we may consider the causes inducing a somewhat regular increase in total yield accompanying the use of larger seed pieces.

Several causes operate to increase the yield when large seed pieces are planted. The larger the cutting the greater generally the number eyes and the number of stalks. The young shoot, before it develops a strong system of feeding roots, is dependent for nutriment on the material stored up in the seed piece; hence the more abundant this supply the more vigorous the growth of the plant and this increased luxuriance is not confined to the early stages of growth, but is marked throughout the growing season. Inrestigation has shown that severing the connection between the seed piece and the growing vine, even after the latter is thoroughly rooted, reduces the yield of potatoes.

The danger of partial or entire failure resulting from an imperfect stand is much greater with small cutting than with large seed pieces. The small pieces with extensive cut surfaces are liable to perish should the season be unfavorable, either through excessive moisture or drought. The sprouts from small cuttings being weaker reach the surface with difficulty, or fail entirely on soil not properly prepared.

\section{EFFECT ON GROSS SALABLE YIELD}

By averaging the results of the experiments referced to above, we find that the actual increase in the potatoes of salable size due to using larger seed pieces was as follows:

Average differences per acre in gross salable yields from different seed pieces.

\begin{tabular}{|c|c|c|}
\hline & Bushels. & Percent. \\
\hline 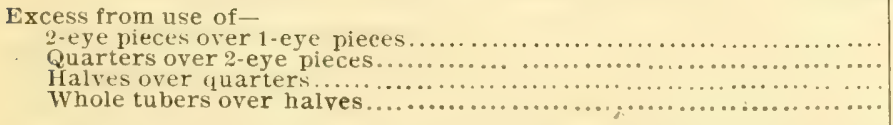 & $\begin{array}{l}23 \\
10 \\
15 \\
14\end{array}$ & $\begin{array}{l}21 \\
15 \\
15 \\
10\end{array}$ \\
\hline
\end{tabular}

Every increase in the size of the seed pieces was followed by an increased gross salable yield. 
Before concluding that the largest seed pieces are the most profitable it becomes necessary to deduct from the crop the amount of seed planted. It is plain that the increas $d$ amount of seed potatoes required when larger pieces are used may more than counterbalance the increasc in yield obtained.

The true test of profit is the market value of the crop produced, less the cost of ser il planted. Should the quantity of seed potatoes used be subtracted from the total yie? d of large and small potatoes or from the salable crop? If small or unsalable seed potatoes are planted, then the former course is the proper one. but since large or medium tubers (either eatire or cut) are generally select d for secd purposes, it seems best to subtract the seed from the salable crop, thus ascertaining the net salable yield.

The following table shows the actual average results for the net salable yicld: that is, the crop a:ter deducting the suall potatoes and the sced used:

\section{- treruye difierence per acre in net sulable yield from different seed pieces.}

\begin{tabular}{|c|c|c|}
\hline & 'Bushels.I & Percent. \\
\hline 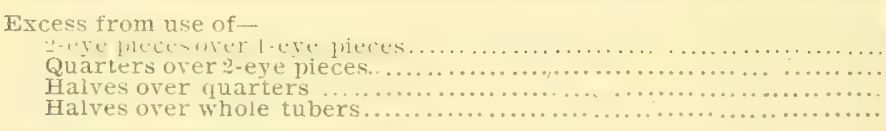 & $\begin{array}{r}15.0 \\
7.0 \\
5.0 \\
8.5\end{array}$ & $\begin{array}{r}14 \\
15 \\
6 \\
8\end{array}$ \\
\hline
\end{tabular}

The amount of the net salable crop rose with the increase in the size of the cutting employed, but when the whole potatowas planted the figures declined on account of the large amount of seed potatoes which had to be deducted. The above figures indicate a very slight advantage in planting halves rather than quarters when the price of seed and of crop procluced are the same. As a matter of fact, spring prices are usually somewhat higher than fall prices. A high price for seed potatoes may make it profitable to plant smaller piezes'as, for example, quarters) than would be economical where seed and crop command the same price per bushel.

\section{GENERAL CONSIDERATIONS ON THE AMOUNT OF SEED POTATOES.}

In the following diagram 100 represents the total yield from planting single eyer. The tigures may be read as hushels per acre, if it is constantiy borne in wind that we are talking about soils of such character as to average 10) busheis of larise and small potatoes per acre when planted with 1-eye pieces.

The lirst group answers the ruestion, "That size of seed pifce generally affords the largest yield of large and small potatoes?" The second group answers the query: "W at size of seed piece generally gives the greatest yield exclusive of small potatoes?" The third group offers an answer to a still more important yuestion: "What si\%e of seed piece generally produces the largest rield after deducting both the small potatoes and the amount of seed planted?" 


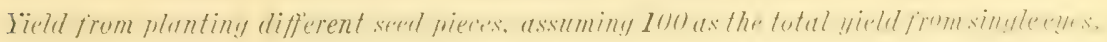
RELATIVE TOTAL YIELD.

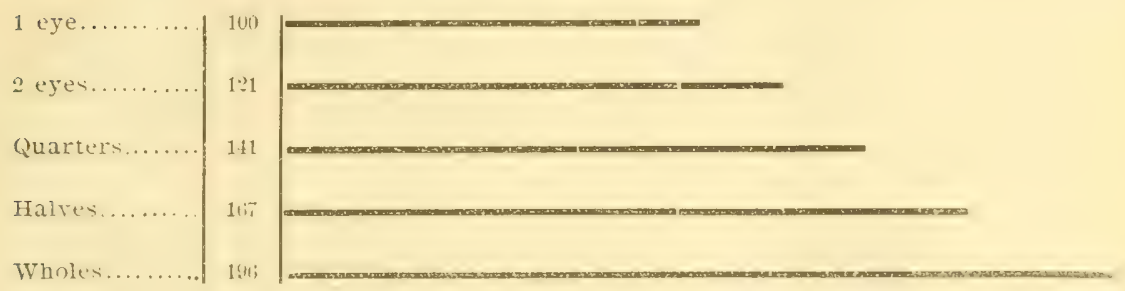

RELATIYE GROSS SALAILE YIELD.

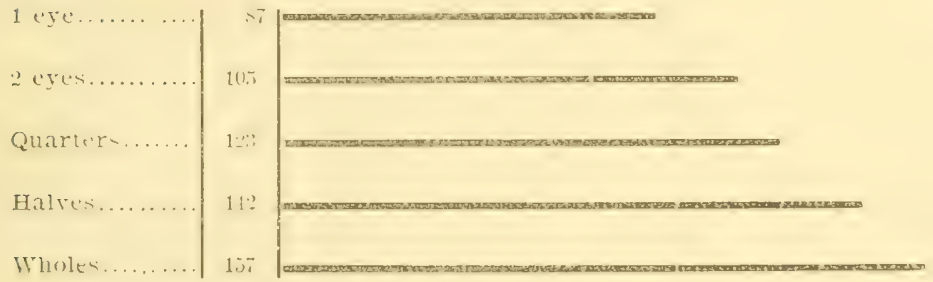

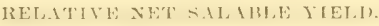

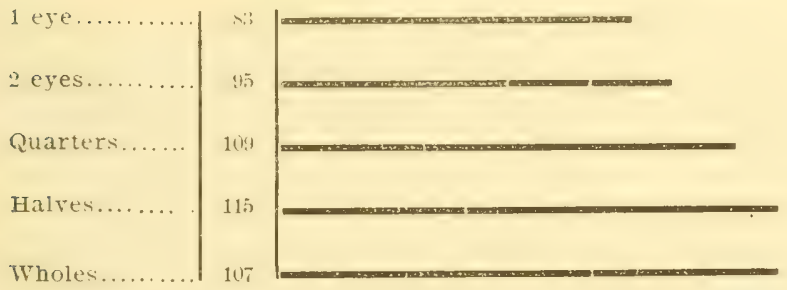

Taking as the correct measure of profit the yield of salable potatoes less the amount of seed used, we see by the third section of the diagram that with seed and crop at 1 he same price per bushel it was more profitabie in these tests to plant halves than smaller'cuttings and whole potatoes.

If we take account of the rield of small potatoes the advantage of large seed nieces is even greater than the firures in the la-t setion of the diagrani would indicate, for the yield of small potatoes is greater with large than small seed piece?. Where large quantities of small potatoes can be profitably utuliz $d$, as, for example, as seed for the second crop, the potato planter may therefore use quite larye sef pieces with advantage.

On the other hand, the high r price of potatoes in spring than in fall is an argument in favor of planıing quarters rather than halves oi whole tubers. A number of investigators have noted that large seed pieces (either large cuttings or entile notatoes) aftord an earlier crop tban very small cuttings, a matter of much intwrest to growers of early potatoes. However, some growers bave repor: ed that uncut potatoes germinate more slowly than large cuttings. Most of those who raise potatoes for the early mariret use large cuttings rather than whole potatoes.

In this connection it may be said that the seed-end half gives an earlier 
crop than the outer half. This suggests the expediency of cutting a potato leagtiwise when halres or quarters are to be planted, thus securing on each liece bine onore of the eyes which germinate first. Another advantage of cutting lingthwise is that it insures a more even distribution of the eyes on the screral pieces. (If course this system is not practicable when very small cuitings are io he mate from long, slender potatoes, since the large amount of expriscu : firface would render the long pieces susceptible to injury both from moisture and dryness.

If it is liesired to cut the potato into small pieces the operator should beGin at lac sicw end, and the pieces shonld be cut in a compact shape, and of as neity winal si\%e as is practicable without leaving any piece entirely devoid of cy. There are special implements for cutting potatoes, and their use is refurtcil as enalliog a man to cut four or live times as many bushels

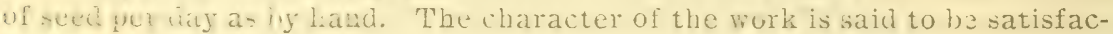
tory.

No definite rule can be given as to the best size of the seed piece, for Lhis depebal, omeshiat o: the distance between the bills and on the character uf the sult and season. Another important factor in letermining the prope ancunt of seci ho lariety. Sume varieties are ahle to produce a crop alusos an labe from small inttings as from large pieces. Thu=, in several Quferwe uts, the rarfety Clark $N 0.1$ has given indications of this capacity to produce well even with light seeding.

\section{SIZE OF SEED TUBERS}

A study of more than a bundred experiments testing the relative values of large, medium and small uncut tubers confirms the general law that an increase in the weight of seec planted allords an increase in the total crop. The yield of salable potatoes increases less rapidjy than the total yield. With whole potatoes as seed the salable yield reached its extreme upward limit in one test when tubers weighing about half a pound were planted; in another when those weighing 4 ounces were cmployed. The limit of profitable increase was reached with tubers wcighing $4 \frac{1}{2}$ and 3 ounces, respectively. The size of seed tubers selected becomes a matter of importance when they are to be cut, for we have seen that the heavier the cutting. the larger the total yield, and seed tubers for cutting should be of such size that their halves, quarters or other divisious shall not be extremely small.

\section{CAN SMALL POTATOES BE PROFITABLY USED FOR PLANTING?}

Whether or not to use uncut small potatoes for seed is an important question on which farmers are divided. Some present the plausible argument that the use of undersized potatoes results in degeneration. If this claim is based on the results of experience it should determine practice, but if the conclusion is simply a generalization based on the fact that large seed. usually give b st results the reasoning is defective, and the question remains open. The potato tuber is not a seed, but an unverground stem, and the relations existing batween seeds and their progeny do not necessarily exist between a tuber and its descendants. Others hold that potatoes just below marketable size, if shapely and suliciently mature, may be used without serious deterioration, and that for economic reasons their use is especially de-

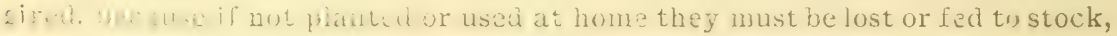
for which purpose their value is usually smaller than the market price. 
The result of tests at a number of experiment stations have uniformly indicated that small tubers uncut can be used for seed purposes without detriment to the succeeding crop. It may still be urged. however, that the choice of small seed year after year will result in degeneration. (1) this question the information is meager, but two experiments, extending orer Cour and eight years, respectively, have been reported in which no degeneracion resulting from the continued usc of small potatoes from the preceling crop was apparent.

Although the exidence seems fairly conclusive that small un tut seed pocatoes may sometimes be used with prolit, we cannot advise that fmall seed cubers be selecteâ year after year from it (rop which has been srown from mall potatoes.

Girardis iarestigations in France justilicel the usual practice of the most orominent agriculturists and horticulturists in carefully selectiog reed potacoes. By sclecting fur several generations average-sized tabers from the oest hills he allectco a considerable improvement in proutuctivencss. To ascertain the best hills by aigging each is exceedingly laborious, but (firard ound that the best hills in an erenly manured field contsiuius only one ra-iety were th se in which the rines wcre most vigorous. Selection was thus -endered ez sy by means of stakes placel besilie the luxuriant plants. This correspondence betreen the vigor of veretation and jield of tubers bas been irequent?y nuted a: the state ag? icultural experiment stations, copecially with secr? ri.ces of difierent sizes. in which case the growth of viucs lis in proportion to the size of the seed piece planted. American experiments indicate some advantage in selecting seed tubers from the most productive hills.

Potatoes of irregular shape and injured tubers should be rejected as unit for planting.

\section{NUMBER OF EYES ANDD WEIGHT PER SEI}

Many potato growers cut tubers into pieces containg one, two or more eyes, laying greater stress on the number of eyes than on the size of the cutting. Extensive experiments at the Indian s station and elsewhere prove that of the two factors, number of eyes and weitht of piece, the latter is more important. Of course it is aesirable that each piece, whether large or small, should contain at least one eye, and it has been generally profitable for it to ba of such size as to contain at least several eyes; kut whether it has one or many eyes it is important that the seed piece be heavy enough to furaish abundant nutriment to the shoots which spring from it. A single eye may give rise to several stalks, for each eye is a compound bucl or cluster of ouds. An eye can be bisected, and each half may then grow successfully if it is not a victim to dryness or decay, to which its exposed condition subjects it.

In one series of experiments it was found that the number of stalks growing in a hill was less dependent on the number of eyes than on the size of the seed piece, whether cut or entire. In general, as the number of eyes per piece increased each eye became less prolific in sending up stalks, so that there was less crowding of stalks where large seed pieces with many eyes were useci than would be xpected irom the large numbir of eyes pianted. After n-merous experiments touching on almost every aspect w this subject the inrestigator alrised that tubers be cut $=0$ as to make each piece of aconstant size or weight, whatever the number of eyes that might iall to iis share. 


\section{NUMBER OF CUTTINGS PER HILL}

A custom not uncommon among those who plant small cuttings is to drop two pieces in each hill. They usually gret a larger yield by so doing than by plantin single pieces, the increase generally, though not always, being sufficient to pay for the excess of see:. This does not prove the practice profitable, for better results may be secured by planting a single piece weighing as much as the combined weight of the two pieces which would have been dropped in one hill. Thus the labor of cutting is considerably reduced and, what is more important, larger pieces improve the chances of get+ing a good stand in an unfarorable seasın, loecause they have less exposed surface than two small pieces of equivalent weight, hence are less liable to dry out excessively when drought follows planting. They are also better able to resist rotting if wet weather prevails.

\section{NUMBER OF STALIKS PER HILL}

The most comuon objection urged again planting large sced pieces is, next to the expense, the dangur of having the bills so crowded with stalks, aut cons: whenely with tubers, that a larese proportion of the putatoes nerer derelop to marketuhe size. The chjection is probally va'id for entire tubers, and also for halves planted very close in the row. The evidence available does not purmit un to conciude thit in the case of quaters used as seed there results any injurious crowding, and it may he questioned whether halves give rise to this trouble wlen planted under favorable conditions and at considerable distance apart.

The number of stalks that can be aảvantageously grown in each hill varies greatly with variety, season, soil, and distance avart. At the Indiana Station it was found that when uncut tubers of 1 to 5 ounces were planted in hills 3 feet apart the gross y iel of large potatoes and the net yield of large potatoes increasea with every increase in the number of stalks per hill ul to 9) stalks fur Burbank and eight stocks for Beauty of Hebron, growing in both cases from tubers weighing $t_{\frac{1}{2}}$ cunces. Eight stalks per hill would probably be excessive for distances less than: feet each way. In experiments in Maine, extending over several years, 6 stalks per hill grave larger yields than 4 to 2 stalks, the amount of seed planted being the same in each case.

As to the effects of thinning the stalks, recordrd experiments are inconclusive, and with ordinary seed pieces it appears to be unnecessary.

\section{DISTANCE BETWEEN PLANTS}

In deciding on the proper distance at which to plant potatoes it is necessary to take into consideration tbe size of the seed piece that is to be emploved. In general, small seed nisces should be planted close and the distance allotted to each hill should be greater as the weight of the piece is increased. Close planting for small cuttings is best attained, not by narrowing the row to less than about $2 \frac{1}{3}$ or 3 feet (for if the distance is much less

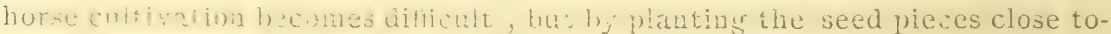
gether in tbe row.

To frame a general rule giving best distances for seed pieces of different sizes is plainly impossible, for the distance at which the largest yields is obtained depends also on the variety, the season, the soil, and the fertilizers. Howere, the resalts of some of the investiotions coreriag this matter afford help in deciding on the proper distance under varying conditions. 
It has been shown that if very small cuttings are used, and if the soil is fertile, the distance can be reduced to (; or!) inches without sacriticing the yield, provided the season happens to be farorable, but this is not wenerally advisable.

On rich s il cuttings of considerable size can be advantageousiy planted as close as 12 inches.

Checkihg ellects a saving of labor in cultivation, and also in planting and harvesting, when these latter operations are performed by hazd: hence expensive labor and the absence of machines for planting and harresting the crop are conditions in favor of caecking. For planting in checks a variety can be chosen which makes a large growth of vines and which forms many tubers in each hill, thus more completely utilizing the space at its disposal than could a variety with small vines and few tubers. In checking there is danger on rich soil that some of the tubers may grow to an objectionable size. Potato growers in attempting to obtain a phenomenal yield, as in contests for prizes, almost universally plant in drills rather than in hills, and place the seed pieces from 8 to 15 inches apart.

The advocates of planting in drills claim that by this methodalarger yield can be obtained, and experience seems to confirm the correctness of this view. The few experiments that bave been made on this question are not entirely conclusive, though the majority of them favor drills.

Although no fixed rule regarding distance of planting can be given, the following general considerations are widely applicable:

(1) For maximum yield of salabie potatoes plant in rows as narrow as can be conveniently cultivated.

(2) Crowd small seed pieces close together in the row, increasing the distance with every increase in the size of the seed piece; avoid on the one hand such close planting as to greatly reduce the average weight of the tubers, and on the other such wide spacing as to leave any considerable portion of the soil unshaded by the full-grown vines.

(3) As a rule, the richer the land the less required distance between sets.

(4) Varieties with strong growth of vines or which set many tubers in a hill should have greater distance between plants than is necessary with less vigorous varieties

\section{CULTIVATION}

Soon after planting, and again just as the young plants are beginning to appear above ground, the field should be harrowed, inclining the teeth of the harrow backward. This is a cheap method of cultivation, since a wide space is covered. It is also effective in destroying small weeds, in leveling the ridges left in planting, in preventing the formation of a surface crust, and in keeping the land covered with a mulch of dry earth, thus conserving moisture within the soil below. Subsequent cultivation should be frequent so as to accomplish these same ends. Almost any pattern of cultivator may be used, provided it is made to do shallow work. However, if the ground has become packed the first cultivation may be deeper. Experience and exact experiments generally favor flat or nearly flat cultivation. Excessive hilling during cultivation intensifies the injurious effects of dry weather. It also results in breaking many of the feeding roots between the rows. The frequent use of the cultivator should be substituted as far as possible for hoeing. If a severe frost is apprehended soon after the plants come up, the tops should be covered by throwing a furrow to each row. 


\section{MULCHING}

While mulching with bay, straw, leaves, or other litter frequently increases the yield and is specially valuable in tiding orer a season of drought, it is not generally practicable on farms where potatos are grown on a large scale. It: place is in the garden rather than in the field. It is a substitute for cultivation, and it is generally cheaper to maintain a soil mulch by frequent cultivation than ro apply litter. If a mulch is $\epsilon$ mployed, it can be applied over the entire surface or in the furrow above the seed pieces, or between the rows. Nulching in the furrow is not commended by the results of tests in Colorado. Louisiana, and Michigan. In striving for a large yield, with little regard to cost, or to insure against drought, mulching is useful.

Material intended to serve as a mulch should first be exposed to the weather, so as to cause the sprouting of any seed it may contain. It is better to apply a mulch after potato plants haye made some growth, as an earlier application may result in smothering some plants and in injury from late frosts.

HARVESTING AND STORING.

The death of the vines is the signal for digging the main crop. For the early market potato growers do not wait for this, but are governed by the size of the tubers. As long as any portion of the vine is green the tubers can continue to grow. At the Vermont station White Star potatoes, planted May ${ }^{\prime}$ ), yiclded 1(i, bushels per acre of merchantable potatoes when dug Auguit 2.: : 2:it bushels Septemler 1; 30:3 bushels September 12, and 35:3 bushels September $\cdots$. More than one-third of the merchautable crop was made after September 1. At the above dates the averare size of all tubers was, respectively, :3.7, 4.4, 5.2 , and 5.7 ounces, respectively. These figures show the importance of protecting the foliage from the late blight by spraying, and they also allord some data as to the rate at which potatoes derelop late in the season.

In garciens very early potatoes are sometimes obtained by carefully removing a few of the larger tubers from the growing plant, replacing the soil and allowing the smaller potatoes to continue growing ("grabbling"). Experiments conducted in Germany by Wollny and Nobbe, and in Austria by I.eydhecker showed little or no loss as a result of this operation carefully done. The large amount of labor required prohibits "grabbling" except when early potatoes are selling at a price rery much higher than can be expected from the later crop.

In harvesting a large area a high-priced potato digger is frequently used; hand digging with a four-tined fork is probably the best method on small areas, though many make use of a potato hoe or of a plow. Careful handling always pays, and extreme carefulness is necessary, especially with the early crop, to prevent injury to the tender skin of the immature potatoes.

In harvesting, as well as in storage, potatoes should be exposed to light as little as possible. In storing potatoes a low temperature is required. The potato tuber is uninjured by a temperature of 33 degrees $\mathrm{F}$., and one authority gives the freezing temperature of potatoes 30.2 degrees $\mathbf{F}$. Warmth favors sprouting, which injures potatoes both for planting and eating.

SECOND-CROP POTATOES.

In most of the territory south of Maryland, Kentucky and Kansas two 
crops of potatoes are frequently grown in one year on the same land. In the warmer portions of these threestates, and indeed a little farther north, a second crop can sometimes be produced. The I gricultural Fxperiment Station at Manhattan, Kans, had fair success when -... days elapeci between planting the first crop and digging the second, hut a wrowing season of 14. days proved too short for two crops.

The second crol is grown by methods somewhat ditlerent from tbose employed with the main crop. Swall potatoes from the early crop are extensively used for seerl, and these should be plantel whole for with nnly a small slice removed), for when cuttings have been planted in lugust or Sentember a poor stand has generally resulted.

It is best to allow the crop which is to furnish seed potatoes for the second crop to remain in the ground until the rines are entirely dear. How ever, the culls may be used even when the early crop is dug beforc complete maturity. To prepare these culls for wrompt growtb and to climinate those too immature to sprout, the small potatoes are expo-ed to the limht in a shady place for several days, or until they hecome rreenish: then ther are spread out on the grouud in a single layer and a little the dirt sifted among them, covered with straw or pine neelles, and the bed kept constantly moist. "The potatoes will sprout earlier if before bedding them under the straw a small piece is clipped ofl' one end and rejected."

Planting time varies from the last of July in Virginia to September in Florida. For the Gulf States, and others with similar cliuate, the usual time for planting the fall crop is the first half of August. Plant without ridering in furrows about 6 inches deep. In the bed select only the potatoes that liave sprouted. Drop them in the freshly opened and moist furrow. cover at once with about an inch of soil, leaving a depressed row to be filled hy subseyuent cultivation. In covering with the hoe the man should walk in the row and thus compact it. Professor Massey recommends the use of a bome-marle coverer consisting of an ordinary plow beam and handle- with a crossbar in front, to which are attached two spiked teeth a foot apart: behind these teeth is a roller. By planting deep the moisture of the soil is made available to the young plants, and by covering lightly prompt growth is insured. For the second crop an early variety should be employed.

The advantage of second-crop potatoes is their superiority in keeping qualities. In a warm climate potatoes dug in June or July can not well be kept without sprouting, and thus injuring their value for eating and planting, while the second crop, dug in October or November, can be kept perfectly through the winter and late into the following season.

Recently the claim has been made that the second-crop potatoes excel ordinary potatoes for seed purposes. It is undoubtedly true that unsprouted second-crop seed potatoes are better than sprouted potatoes from the main crop. This makes the use of second-crop seed popular in portions of the South where unsprouted seed potatoes are difficult to obtain. Recent experiments at the Kansas Experiment Station indicate a superiority for second-crop seed even as far north as Manhattan, Kans. There in 1890 secondcrop seed produced a crop 27 per cent larger than main crop seed of the same varieties. In the following year the excess was 70 per cent in favor of seed potatoes of the second crop.

Whether or not the continued use of second crop seed propagated by means of culls results in degeneration seems at present an open question. 
Many sucessful growers have employed second crop seed for a number of yeari in succession. Many of those who grow early potatoes for market use northerm seed in spring to ohtain potatoes for planting the second crop, which in turn is intended as seed for the next carly crop. Thus the advantaves of second (rop seed and of frequent renewal of the stock are secured.

\section{SUMMARY.}

(1) A rich, sardy loam, well drained and well supplied with vegetable matter is the best soil for the potato. Stiffer land may be improved as a potato soil by green manuring and drainarye, and lighter solls can often be made sufficiently rich by the addition of green manures and fertilizers.

(*) Potatoes should not, as a rule, be grown continuously on the same land, but should be alternated with other crops. Barnyard manure may be freely used, but should, as a rule, be applied to previous crops in the rotation.

(3) If commercial fertilizers are used, a mixture containing nitrogen in form of nitrate of soda, phosphoric acid as superphosphate, and potash as sulphate, and in which potash predominates, is recommended.

(4) Preparation of the land should be deep and thorough.

(i) Planting without ridging generally affords the larger yields, but a stiff soil and the desire for an extra early crop sometimes necessitate planting on ridges.

(i) The best time for planting depends on the climate of each locality. The planting should be so timed as to bring the period when the tubers are rapidly forming at a date when the average rainfali is ample.

( 7 ) On mellow, well drained soil decp) planting (3 to i) inches) is best, especially when the season happens to be dry. For the early crop, or on stiff soil with a tendency to bake, the depth of planting may be decreased.

(\&) The use of the harrow before the plants are all up and frequent shallow cultivation afterwards, until the vines shade the land, are advisable.

(9) Seed potatoes grown in New England in several tests proved superior to Maryland seed both in New England and in Maryland. However, the data seem insufficient to determine definitely the relative value of seed potatoes from different climates.

(10) Cutting the seed pieces a few days before planting appears to exercise no injurious influence, provided, of course, that the cuttings are carefully stored in the interim.

(11) The yield from planting the seed or bud end is generally greater than from the stem or butt end of the tuber. The eyes on the seed end are the first to germinate, and bence are especially important when an early crop is desired

(12) Exposing unsprouted tubers in a warm place before planting hastens growth, but if continued until sprouts form (which are rubbed off) the yield may be considerably reduced.

(13) Experiments indicate that it is more important to cut the tuber into compact pieces of nearly uniform size than to so shape the pieces as to have a definite number of eyes on each set. No piece should be entirely devoid of eyes, and the majority of the seed pieces should be large enough to support at least two eyes, and better three or more.

(14) At distances of 1 by 3 feet, and with seed tubers averaging 4 ounces, an acre requires of quarters about 15 bushels.

(15) The total yield increases with every increase in the size of seed 
piece from the single eye to the whole potato. This increase occurs hoth in the large and in the small potatoes, but chiefly in the latter.

(16) The gross yield of salable potatoes (largre and medium) also increases with the size of the seed piece from one eye to the whole potato.

(17) Tae net yield of salable potztoes (found by subtracting the amount of seed potatoes and the yield of small potatoes from the total yield) increases with every increase in the sime of seed piece from one eye to the half potato. The half potato affords a larger net salable crop than the whole potato, on account of the excessive amount of seed required in plantings entire tubers. Taking the average of many experiments, it was found that for every 100 bushels of net salable crop grown from single eyes there were $11 t$ bushels from 2 eye pieces, 131 bushels from quarters, and 1:3!) bushels from halves, but only 129 bushels from planting whole potatoes.

(18) These results favor the use of halves as seed pieces if seed potatoes and crop are assumed to be of $\epsilon q u a l$ value per bushel, but when seed potatoes command a very high price quarters may be used to advantage.

\section{Potato Diseases and Their Treatment}

\section{INTRODUCTION}

A number of diseases aflect the Irish potato in this country, and the losses they occasion are often a serious drain on the farmer's income. The object of this bulletin is to briefly describe the most important diseases and to outline methods of treatment which experience has shown to be successful in holding them in check.

\section{POTATO LEAF BLIGHT, OR EARLY BLIGHT}

\section{(Alternaria solani (E.\& M.) Sorauer.)}

This disease is widespread and destructive. It is confined to the leaves and green stems, and appears about the time the tubers begin to form, but may be noticed earlier if the growth of the plants has been checked in any way. The first indications of its presence is the appearance on the leaves of grayish brown spots, which soon become hard and brittle. The disease progresses rather slowly; the spots gradually become larger, especially along the edges of the leaflets. At the end of ten days to two weeks half of the leaf surface may be brown, withered, and brittle while the rest is of a yellowish green color. Three weeks or a month may elapse before all the leaves succumb. The stems in the meantime remain green, but they too finally perish through lack of nourishment. The tubers stop growing almost as soon as the leaves are attacked, and as a result the crop is practically worthless.

TREATMENT

Early blight may be held in check by the application of the fungicide Bordeaux mixture. This is prepared and applied as follows: Pour into a 50gallon barrel 25 gallons of clean water; then weigh out 6 pounds of crushed bluestone, or copper sulphate, and after tying it in a piece of course sacking suspend the package just beneath the surface of the water by means of a string tied to a stick laid across the top of the barrel. In another suitable vessel, such as a tub or half barrel, slack 4 pounds of fresh lime. Slack the lime carefully by pouring on small quantities of water at a time, the object being to obtain a smooth, creamy liquid, free from grit. When the lime is 
slacked add sufticient water to make 2-) gallons. As soon as the bluestone is dissolved, which will require an hour or more. pour the lime milk and bluestone solutions torether, using a separate barrel for the purpose and stirring constantly to ellect a thorough mixing. It sometimes happens that sufficient lime is not addcr, and as a result the foliage may be injured. To be certain that the mixture is safe, hold a steel knife blacle in it for two or three minutes. and if the polished surface of the blade shows a copper-colored tinge add more lime, but if it tays bright the mixture is safe to use. Application of the mixture should begin when the plants are 4 to 6 inches high, and should be repeated at interva!s of twelve to fourteen days until five or six treatmen's have been made. IBy adding $x$ onnces of Paris green to each barrel of the Ijordeaux mixture a combined fungicicle and insecticide is obtained, and thin will prevent the attack - of the Colorado potato heetle. the liea beetle. and other insects. Bufore adding the Paris green it should be mixed with a small yuantity of water, and when a thin paste is obtainea this should be thoroughly stirred into the barrel of Bordeaux solution.

The succers attending the application of the Borde?ux mixture depends in large measure upon the thor,ughness with which it is applied. To reach all parti of the plants above ground with a fine spray reruires a grood force pump and a suitible nowle. The knap-ack sprayer, now on sale in nearly every section of the country, will be found one of the most useful machines for sprayin tields of :; azres or lesi. lor larger plantations more powerful macnı - nhould ba used. A cheap and sarviceable apparatus, well suited for this work, may be made by mounting a good, strong force pump on 'a barrel. and then placing the barrel and mounted pump in a light wason. The entire outlit, including barrel, pump, hose, nozzles, operator, and boy to drive, may be drawn hy one horse. As the wagon is drawn slowly between zhe rows the man in the wagon may operate the pump and at the same time time keep the mixture stirred. while two others on the ground hold the nozzles and direct the spray over the plants. The noz\%le found to be best suited to the work is the Vermorel. This is now offered for sale by pump manufacturers and dealers in sefds and agricultural implements in various parts of the country. Where there are only a few plants to treat. simple devices for the application of the fungicide, such as watering cans, the syringes used by florists, etc., may be 'used.

\section{POTATO BLIGHT, LATE BLIGHT, OR ROT}

\section{(Phytophthora infestans (Mont.) de By.)}

This disease attacks the leaves, stems, and tubers. Generally the first noticeable effect upon the leaves is the sudden appearance of brownish or blackish areas, which soon become soft and foul smelling. So sudclen is the appearance of the disease in some cases, that fields which one day look green and healthy may within the next day or two become blackened as though swept by fire. The rapid spread of the disease, which is caused by a parasitic fungus, is dependent in large measure upon certain conditions of moisture and heat. A daily mean or normal temperature of from 72 degrees to 74 degrees $\mathrm{F}$. for any considerable time, accompanied by moist weather, furnishes the best conditions for the spread of the parasite. On the other hand, if the daily mean or normal temperature exceeds 77 degrees for a few days, the development of the disease is checked. This fact explains why the fungus seldom occurs to any serious extent in sections where the mean or normal 
daily temperature excects 7 ilegrees for any length of time, and probahly why it appears later than the clisease discussed under the former heading.

The tuber allected with the disease show depressed, dark-colored areas on the surface while within are blotches and streaks of a brownish or blackinh color. Other diseases may produce similar effect. so that in this case the changes are not so characteristic as those shown by the leaves. Fur many yearsit wan believed that most of the injury to the potato wan clue to this diseare, but recent in restigations have shown that view to he erroneous.

TREATMENT

The same treatment as recommented for early hight should he followed here, and will be found to prevent the l,lighting of the tops and rotting of the tubers. In regions where late blight is known to occur. care should be taken to hegin the application of the Bordeaux mixture before the attaiks of the fungus. In all this work it must be constantly kept in mind that the main object is prevention rather than cure. Benefit will undoubtedly result if only clean, healthy potatues are used as seed. Decayed and discolored tubers should be fed to the hogs, as it is poor policy to plant them.

\section{BROWN ROT}

\section{(Bacillus solanacearum Smith.)}

This disease occurs in many parts of the South, and in addition toattacking the potato, is found to seriously injure eggplants and tomatoes. In the case of the potato, the leaves, stems, and tubers are allected. The disease usually manifests itself by a sudden wilting of the foliage and soon the whole plant may become aflected, the leaves and stems shriveling and then turning brown or black. The disease reaches the tubers through the stems, producing a brown or black discoloration of the tissues and ultiwately a complete breaking down or rotting of all the parts. Brown rot is caused by a bacillus, a minute organism, which multiplies in the tissues and through its action produces the eflects mentioned. Various insects, such a Colorado beetles, flea beetles, and blister beetles, serve as carriers of the disease. These insects may feed on d diseased plant, and in their visits to adjoining healthy ones infect the tissues through bites and possibly in other ways.

TREATMENT

Throughout the South, namely, in South Carolina Mississippi, Alabama, and adjacent States where this disease is known to occur, a thorough system of spraying, such as recommended for early blight, should be followed. In addition, all diseased vines should be removed and destroyed as soon as possible, and the tubers should be dug and either used at once or stored in a cool, dry place. In planting it would be well to avoid land which has just been used for tomatoes or eggplants, and finally seed tubers from localities where the disease is absent should be used if practicable.

\section{POTATO SCAB}

\section{(Oospora scabies Thaxter.)}

Scab is one of the most widespread diseases affecting the potato. Injuries of various kinds may produce a roughened surface, but it is safe to say that most of what is known as scab is due to the attacks of a minute parasite fungus, first studied and described by Dr. Roland Thaxter, of Harvard Uni- 
versity. The effects of the disease on the tuber are plainly noticed in scabby patches and blotches are su common we believe any one can identify it.

\section{TREATMENT}

I'otato scah may be successfully coutrolled by treating the seed before planting. Two fungicides are used for the purpose namely, corrosive sublimate solution and fo:malin solution. To prepare the first, dissolve? ounces of corrosive sublimate, or bichloride of mercury, in about 2 gallons of hot water and after ten or twelve hours dilute with clear water so that the whole (juantity makes 1; gallons. Corrosive sublimate is a poison and must therefore not be placed where it can fall into the hands of children or irresponsible persons. To prepare the formalin solution, mix 8 fluid ounces of commercial formalin (otherwise known as 40 per cent formic aldehyde) with 15 gallans of water.

To treat the potatoes with the corrosive sublimate solution, immerse them for an hour and a half in the liquid and then spread out to dry.

Finally cut and plant in the usual manner. A large barrel is a convenient receptacle for the solution. The potatoes may be placed in a coarse sack and suspended in the liquid, care being taken to wash the tubers before dipping, provided they are very dirty. All treated tubers should be planted in order to avoid danger from the poison upon them.

It has been shown that the formalin is fully as eflective against scab as the corrosive sublimate solution, and as it is far less dangerous it will probabably come into more general use. In treating seed with this preparation the whole potatoshould be soaked for two hours in the solution already described. After soaking, the potatoes may be dried, cut and planted in the usual way, care beingtaken not to allow them to become contaminated by coming in contact with bags, boxes, or bins where scabby potatoes have been kept In practice it is found that 15 gallons of either of the foregoing solutions will be sufficient to treat 20 to 25 bushels of potatoes, taking ordinary precautions of course not to waste too much of the fluid as each lot of tubers is dipped.

TIP BURN, LEAF BURN, OR SCALD

This disease of the leaves occurs in many parts of the country and is often confused with early blight. The tips and edges of the leaves turn brown and these discolored areas soon become hard and brittle.

The burning or scalding may occur at any time and as a rule is the result of untavorable conditions surrounding the plant. Long continued cloudy and damp weather followed by sezeral hot and bright days is very apt to result in the burning of the foliage. This is especially the case on soils carrying a comparatively small percentage of moisture. When the weather is cloudy and damp the tissues of the potato become gorged with water and this has a tendency to weaken them. If the sun appears bright and hot while the leaves are in this condition, there is a rapid evaporation of the moisture stored up in their cells. The evaporation may be faster than the supply furnished by the roots, and if this continues for any length of time the weaker and more tender parts first collapse, then die, and finally turn brown and dry up. Tip burn may also occur as the result of protracted dry weather. 
Numerous factors are involved in the matter, so that only general statements are possible. Every ellort should be made to keep the plants in good growing condition, for if they become checked through lack of proper food or cultivation or both they are more apt to burn. It is a fact that where the Bordeaux mixture is used for other diseases burn is less a jt to occur, and this furnishes another instance of the remarkable properties of the fungicide. Brielly, therefore, the plants should be kept as vigorous as possible by good cultivation, plenty of available food, and the application of Bordeaux mixture, as recommended for early blight.

\section{ARSENIAL POISONING OF POTATO LEAVES.}

In many sections where Paris green in water is applied to potatoes injuries are produced which cannot be distinguisned from early bli rht hy auy ordinary examination. It frequently happens, therefore, that farmers are led to beliere that their potatoes are allected with early blight and other diseases when the trouble has been brought on by themselves through the improper use of Paris green. Injuries resulting from the liee of this substance are very apt to occur where llea beetles hare eaten the foliage. Tne arsenic attacks the tissues at such points, and as a result more or less circular brown spots are produced, having for their centers the holes caten out by the llea beetles. By combining the Paris green with Bordeaux mixture, as already described, these injuries may be wholly avoided.

\section{CONCLUDING REMARKS.}

The cost of the work of spraying as described here will depend to a considerable extent upon the kind of machinery used and the price paid for labor. With suitable apparatus and labor at $\$ 150$ per day; potatoes may be sprayed six times for about $\$$ per acre. This estimate is based upon experiments extending over several years and includes the cost of chemicals as well as labor. The cost of treating scab is mainly in the labor involved in dipping and drying the seed and seldom exceeds 1.; cents per acre. Much attention has been given to the eflects of Bordeaux mixture on the growth and yield of potatoes aside from its value in keeping parasitic foes in check. It has been shown conclusively that it pays to apply thispreparation if for no other purpose than to induce a more vigorous growth. Three or four applications of the mixture have in many cases increased the yield of potatoes 50 per cent, so that no matter where the crop is grown or whether disea-es are present or not the writer feels warranted in recommending the application of the mixture on the ground that its use will yield a handsome return.

\section{Humus in the Soil}

DON'T FORGET IT-YOU MUST HAVE HUHUS IN THE SOIL

It seems like telling the same story over again, but we must talk a little more about humus, or the vartially decayed vegetable matter in soils. You see that feliow on the adjoiniog farm who is p'oring and puttine in corn the third year in succession. He will put in oats next year, spring wheat perhaps the next and then take three more crops of corn and sell it all on the market. He js probably a renter on a year's lease and has a landlord who does not know anything about farming. What is that landlord forcing the tenant to do? Rob the soil of the humus. For what did the Lord of all farms put that humus in the soil? He had tro or three things in mind. ()ne was 
to warm it up in the spring by its slow decomposition. Another was to enable it to ahsorb water in a wet time and to hold it and give it out slowly in a clry time. Another was to keep the soil particles apart so that they would not bake, and anotior was to keep it from washing. Still another was to have ou hand a constant source of nitrogren, and another, a source of carbonic ac d hy inears of which the plaut roots could take up the mineral matier. That is what the lord of the farm and of the soil had in riew when he commenced putting humus in all soils capable of sustaining vegretation. And now this fellow is spoiling the work of the great master. He is trying to exhaust that humus. The more he cultivates it the more rapid is the action of the atmosplere, aud in time he will have nothing but gas, which has gone into the air and ashes which remain in the soil, and his soil will become a muck in a wet time and bake in a dry time. It will have no reserve moisture. If will wash away by the rains and the fellow will think that the soil has been exbausted. Probabiy it might be as well to let him think so and go eli sominhere else. In point of fact, however, it is not exhausted, and there is just as much potash and phosphoric acid in the soil as there ever was, only the great warmer of farmers has locked it up, turnded the key and put it away where this fellow will not find it.

Now, just this is tiae irouble witl nearly every soil naturally sood that it is said to be exhausted in all these states of the central West. That is the irouble over in illinsis ou lands rich beyond the dreams of avarice 1 hat are being rented year after year for grain crops until they are refusing to respond and the fel'ows think the clinate has changed or there is somrthing wrong with the administration. That is the trouble with rented farms all

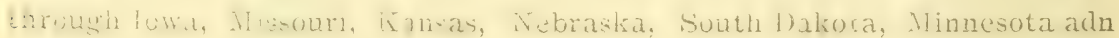
away out in the Red River valley.

If you will go with me to portions of Mississippi, Alabama. or Florida, I will show you tnousands of farms with their once beautiful mansions, surrounded by parks, trees and shrubbery, which today are a total wreck. Thousands of acres of beautiful farm land on which apparently nothing will grow except shrub palmetto and sickly wire grass and yet at one time those farms were wor: h from $\$ 100$ to $\$ 200$ per acre, today they may be bought from $\$ 5.00$ to $\$ 20$ per acre. And why? For years they grew cotton which was sold throughout the world and made their owners rich. The day of judgment has passed, the richness (f the soil was sold, the land was literally robbed, no humus left. The soil once black and rich, today has the appearance of bleached ashes, no life, and cannot respond to the farmer's call until it has been recuperated with that which brings new life and no one plant can so surely rive the needed relief as clover.

We do not blame the tenant, who probably cannot holphimself, but the owner ought to know better, and if the tenant does not know better it is time for him to subscribe for an agricultural paper and learn something.

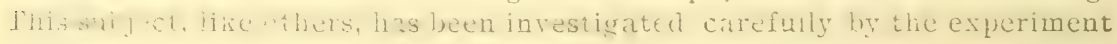
stations, and the following is the result in Minnesota:

Where there is 33 per cent humus in the soil at the beginning, four years' cultivation in given crops brought it down 3 per cent; one-seventh of it was gone. On a plat of similar soil, part of the same plat, where the rotation was wheat, clover, wheat and oats, one crop of clover in four years, the per ecut of humus rose to :in per cent, showing how easy it is not merely to stop She waste. but to actually increase the humus in the soil. For better bring- 
THF STUDY OF PHYSICAL GEOGRAPHY UY THE FARMER.

In the meantime, what is the practical farmer to do, who realizes that he does not possess the knowledge of physical geography and geology necessary for intelligent comprehension of the practical problems in connection with the tillage of the soil, in order to supply the defects in his early education?

First. let the farmer procure a copy of any one of the numerous standard modern elementary text-books of physical geography. No farmer of average intelligence and a fair knowledge of the English language, who will bring to the task a mature mind, more or less practical experience and observation, and an earnest desire to learm. will firl any difficulty in mastering the subject, as set forth in such a text-book, in a very short time He will not find it necessary to learn so very much that is entirely new to him, but he will be brought to see the relations and bearing of many facts that he was a!ready familiar with. He will frequently be -urprised to discover what a fund of valuable information he had sathered from experience and observation, l, tt had not been al, e t. use because his attention had never been called to the bearing and relation of these facts.

If there are youn members of the family who are studying or have studied physical weonraphy in schoul, they can materially assist their elders in the study: and, furlh roore, it will be a great stimulus to these young reople if they find the subject has a practical side of such importance that their parents are interested in it. The practical knowld dge and experience of the mature man will supplement the theoretical knowledge of the student, and they will be mutually helpful to one another.

THE STUDY OF GEOLOGY BY THE FARMER.

Hav'ng become familiar with the subject of physical geography, the next step should be to take up the study of some elementary work on geology. In selecting a text book the name of th:author is not of so mach importance as that the work itself be up to date. The science of greology is advancing so rapidly that all the publishers of standard text-books find it necessary to make frequent revisions, and only the latest editions should be used. It is a (quite generally accepted opinion among those who have never studied geology that it is so profound not to say mysterious, a science that only those with college training can comprehend it. Such an opinion is entirely erroneous: for while it is true that the geologist who wculd undertake original investigation, either in the field or in the laboratory, must be well grourded in the sciences of mineralogr, chemistry, l hysics, biology, astronomy, and mathematics if be expects to take at place among the leaders of the profesion, it is a no true that the-e investierators are able to expound many of the compl. $x$ problems in scolngy in lanwuage carily c: mprehended by any person of ordinary calication: and this has bien done in ti elemutary textbooks in use in the schools.

In no other vocation, with the possible exception of mining, is a knowledec of the fundamental principles of erology more necestary than in farming. It might even be questioned whether the miner is able to utilize the teaching of geology as fully as can the farmer; for while the miner must posess some knowlenge of structural geslorg. gaincd eitber from bouks or from espresece and observation, the farmer finds a lspowledge of all the subli virion- of gevlogr eymally serviceable to him. A knowlectge of dynamic, 
structural and physiographical geology gives him an insight into the origin and characteristics of the soil, the tillage of which constitutes so larre a part of his vocation, while a knowledgre of historical geology shows him how all the plants and animals with which he has to deal have slowly developed from lower and simpler forms. In fact, the work of the farmer and stuck breeder in improving cultivated plants and domesticated animals is simply a continuation of the process of improvement carried on by nature before man existed and for a long perict after his alrent, and before he had dereloped in the scale of intelligence to the point where he began to recognime the benefit to himself that would result from his taking advantage of the corces of nature to shape animals and plants to his rapidly increasing recls and want:

There are very few practical farmers who will not find it profitabie to devote souse time to the study of pbysical geogrally and geology af ter thelr minds have matured and they have aciuired a store ff practical esperience.

The extent to which the study should be carried must necessarily be determined by the tastes and intellectual bent of the indiditiai concerued, hut it should certainly be sufticient to enahle him to read intelligently the whrous reports i-sucel by the l nited States and his own -tate geological surrey. He should wake himself thoroughly familiar with these reports. at leat so far as they deal with the conditions in his own state, or with broader and more general problems with which he has to deal as a mactical farmer and business man In this day of world-wide competition it is not sullicient that the farmer shall be acyuaintra with his local conditions only. He musi fromsess a general knowledge of the conditions surrounding those with whom he is to compete in supplying the world with its food products. Commercial geograpby is a subject with which all producers as well as all dealers should be familiar.

No doubt many farmers who read the above will say that this is simply theorizing, and that it is not practicable for a farmer to undertake such a course of study. It is hoped that the writer may be excused for stating that he is and has been for twenty years a practical farmer, and that the above opininns are the outgrowth of his personal experience as such.

\section{ESSENTIALS FOR THE PROGRESSIVE FARMER}

With the knowledge above suggested the farmer is in a position to keep abreast of new levelopments along agricultural lines by kiceping in close touch with the agricultural college aul experiment station of his own State and with the Uaited States Department of Agriculture. He will also be in a position to take up lines of investigation and experimentation for himself on his own farm that will not only add to his prosperity, but will give him a added interest in his farm life.

HOME STUDY OF SOH, PHYSICS

In nearly all of the more progressive agricultural colle ges of the country,

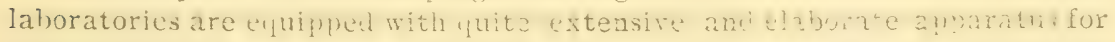
the study of soil puysic;, as is fully described and illus'ratcd in a recent publication of the United State. Department of Agriculture. " 5.11 farmers who can take a course in soil physics in one of these institutions should do so; but there are thousands of intelligent, progressive farmers who cannot spend the necessary time away from their farms. These farmers, however, need not feel diszouraged. There are a great many very important problems in soil physics that 
must be solved on the farm if they are ever to be solved, and, indeed, the value of laboratory training and study depends entirely upon the character, experience, and practical knowledge of the soil, and its behavior under actual lield conditions, possessed by the teacher. The ultimate object of all study of soil physics hy those who are titting themselves for practical farmers is to become so thorougly acyuainted with the various types of soil with whicli they are likely to have to deal in actual farm operations that they will be able to rexomnice tirem as soon as they see and handle them, and to know the crop-producing powers of each unter the conditions where they are found: to be able tu devide what methods of tillagre will place each in the best fucsilule condition for the crop to ba grown upon it under varying climatic a Bulletin No. 12i of the Ofice of Experiment Stations.

conditions, and how best to supply any lack of food that may exist.

There is no doubt that most of this knowledge must be acquired in the lield, under actual farm conditions. Laboratory methods of instruction that will assist in acquiring this knowledge without obscuring the objects sought are to be commenied. But the time and energy of the student must not be so taken up with mastering the details of the methous adopted for establishing certain facts as to lose sight of the ohject for which these facts are sought. The teacher must constantly keep before the mind of the student the practical application of the principles demonstraced in the laboratory.

STUDY OF MECHANICAL CHARACTERISTICS OF' SOILS

Every practical farmer should know something of the mechanical charicteristics of ditrerent types of so:1, and particularly of those with which he has to deal on his own farm. If he can bave made for bim, by some competent person, mechanical analyses of the various types of soils with which he has become acquainted through prictical experience and observation, he will be als e to ste the catuses of some of the prollutive peculiarities of these soils that he has aiready observed but cannot explain, and in many other ways the knowledge gained from these analyses $v$ ill be of value. For a practical farmer to undertake to become an expert sil analyst is however, a waste of time. The same may be said of nitrogen and specific gravity determinations and many other laboratory proc sies required of students in some of the agrizultural cullsges. "Art for art's sake" is nowhere more out of place than in laboratory instruction in soil physics for the praciical farmer.

REQUISITES FOR THE SUCCESSFUL TEACHER OR INVESTIGATOR

The above remarks do not, of course, apply to those who are fitting themselves for teachers or investigators in the theory of soil physics. for to them laboratory mork is of the bigaest importance, and such work offers a very in. viting field of usefulness for those who are fitted for it. It is most important, however, trat every teacher or inrestigator in agriculture should be thoroughly familiar with the soil and all farm operations. He should know bow the dirl rent soils behare under different methuds of tillige in the field, uncler all the varying climatic conditions that are to be met with in the conutry where he is located; and in addition to this he should have a broad general knowled re of conlitions. method-a aud results in other parts of the worli Hestrould have a good working knowlerl ge of greology, physics, and chemistry, in so far as they apply to the soil and plant production, and he should not only he familiar with the results ohtaincel by specialists in laboratory investigation. in soil physics, but also with the methorls used in their 
inrestigations. Without these qualifiations he cannot be a succesiful teacher.

The farmer sbould have the same general knowledge of the soil, agricultural methods, and climatic and economic conditions as is neeled by the teacher or investigator. He should alio ba acquainted with the results obtained by these investigaturs, though he need not be able to perform the laboratory manipulations. There are thousands of suciessful businesi men who never attended a business college and who know nothing of the methods of instruction employed in them. Altbough many of our hest famers attained their success without dire:t assistance from the arricultural colleges and experiment stations, all of them have profitel very largely from the indirect benefits they have receivel from these institutions, which have, by investiGation and teaching, adcled so enormously to the general store of knowledge. This knowledge has become pub ic property, and has benefited thousands of men who have never come in direct contact with any of these institutions.

\section{RELATION OF THE SCIENTIST TO THE FARMER}

Farmers as a class are conservative, and they have not been as quick to grasp indirect benefits as those engaged in other vocations. 'The reason for this is largely their failure to realize how, by a little efiort on their part, they can fit themselves to make arailable the vast stores of more or less theoretical knowledge accumulated by the scientists.

On the other band, there has been, and still is, a tendency on the part of some scientists to balittle the ralue of the knowledge and experience of thcse unacyuanted with the mere macbinery that they bave used in obtaining their knowledge. A better understanding is, however, being brought about between the practical farmer and the experiment-station worker. The very best men in the agricultural colleges and experiment stations frankly admit that many practical farmers who know litt!e or nothing of the methods adopted by scientists, nevertheless, have. by observa:ion and practical experience, gained such a knowledge of the soil and its requirements for crop production that they can. from a simple examination of the soils with which tbey have become acyuainted, make a rcliable estimate of their cropproducing capacity

What is needed is that the scientist should be thoroughly acquainted with the soil acel p'ant growth under actud lield conditions, and should know the actual results of the various methods of tillage and farm management, although he does not perfurm any of the actual operations of the farm himself, and that, on the $o^{\prime}$ her hand, the farmer, should keep himself posted as to the actual results of the investigations carried on by the scientist.

All information given to the farmer by the scientist, either in the class ro' $m$ or through the publications or pullic lectures, should de 1 with results and not with details of the methods by which those results were obtained. Only such information should be given concerning the details of the methods used to t's obtain the results as will enable the farmer to $j$. die intelligently of the value of those results. And in giring these details the scientist should be ahsolutely frank in admitting the defects and limitations of his methols. Field conditions cannot be duplicated in the laboratory, and laboratory results will not hold good under field conditions, although certain general principles may be demonstrated by laboratory methods. 


\section{CROP ROTATION, METHODS AND VALUE}

Among the many problems that may and should be worked out both at the agricultural experiment stations and upon private farms, few can be found that are of greater importance and of more universal application than that of crop rotation.

Some very significant facts are brought out in the article upon "Practices in crop rotation," contributed to the Yearbook for 1902 by George K. Holmes, of the Division of Statistics. Department of Agricultural. He says:

"Haphazard is a mild word to describe the jmpression given by the reports of the correspondents with regard of the rotation of crops in many countics and parts of counties of the Iuited States. Although there may be an annual change of crop on the same land. this change is souncertain, so unsystematic, that at first it seems imposible to establish order out of the chaotic mass of particulars."

In another place Mr. Holmes says:

"A diminution in the degree of rotation hardly appears until Ohio is passed, and then the diminution is ar dhat ustil in the longitude of midcle Kansas rotation is of the simplest, when existing at all."

In the same article, speaking of the use of fertilizers, is the following:

"There are still extensive regions in the United States where barn manure is considered a farm nuisance. In a county in Oreron the neighbor is welcome to haul away this manure, and that neighbor islikely to be a thrifty German with a larse garlen: in other ()regon counties the mauure is burned. In a california county the manure is lumped into ravines: it goes to the creek in Oklahoma: it is hauled to a hole in the ground or put on one side of the field in Kansas: South Dakota farmers burn it to be rid of it, and sometimes burn it for fuel. In North Dakota farmers haul barn manure to piles and leave it there until it disappears: farmers in Missouri deposit it by the roadside, and in Idaho scrapers are used, and it is 'often seen piled as high as a barn.'

In many counties between the Mississippi River and the Pacific Ocean farmers not only find barn manure a nuisance, but they have a grierance against it, claiming in South Dakota that it proluces dog fennel, elsewhere that it produces other weeds, and in various counties that it has such an effect of 'poisoning' the soil that farmers are afraid of it."

The foregoing statements are all true but they ought not to be. One can not help exclaiming in the worts of Polonius, "Tis true tis pity: and pity 'tis "tis true." Not only are these statements true when applied to the localitier mentioned, but they wculd be equally true of many other localities.

The farmers are not alone to blame for this condition. In the article ruoted the statement is uade that "The farmer is in a rut, lacks initiative, and needs help to get out." This is true and to a certain extent always will be. Are the agricultural colleges and experiment stations doing all they might do asd ought to do to help the farmor out of this rut? In soue states, yes; in others, no. It would not be difficult to name some agricultural col-

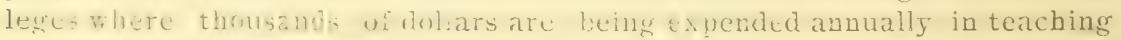
youre farmers bow entmcal anci physical ana?ys s are made where abolutely nothing is being done in a practical, systematic, scientific way to test the value of crup rotation and the application of manures under ordinary field conditions. Is there zot, thun, some ground for the "contempt of hook farming " mentioned by $M /$ r. liolmes as being felt by some practical farmers, anci 
are not the colleges and stations in part to blame for the condition mentioned?

WORK IN CROP ROTATION AT EXPERIMENT' STATIONS.

There may be experiment station farms in the United States where it is impracticable or needless to carry on work in crop rotation but it would be difficult to imagine where they are located. Most, if not all, should be carrying on experiments, not with oye but with many systems of croprotation. This work should be carefu ly planned and systematically and uninterruptedly carried on for a long succ sssion of years. In fact there is no limit to the length of time to which it should be extended. It will become more and more valuable as time goes on. It should embrace not only those rotations which the experience of practical farmers has indicated as best adapted to the local conditions in the state; but it should also include others, both good and bad; those that seem to be bad may prove to be good, and those that prove to be bad may be as valuable, as object lessons, as those that give better results.

In connection with this work of crop rotation many other lines of work could be carried on, such as studies in the movement and conservation of soil moisture, application of fertilizers, methods of tillage, nitriflcation, leaching of soils, efrect of green manuring, and the growth of leguminous plantsetc. But these should be considered as accessory to the main problem of crop rotation Crop production through a long term of years should be the crucical test of the value of any rotation, and these results should never be obscured by the introduction of any side line.

As a rule, it will not be advisable for the practical farmer to carry on more than one, or at the most two, rotations on any one farm. A system of crop rotation should be planned to last for generations, and should not be undertaken without careful consideration. The farmer should become thoroughly acquainted with the subject befure be adopts any system. This he ought to be able to do by applying to his own state experiment station The men in charge of the work there ought to be able to furnish him with more, and more valuable, information than he can obtain from any other source. Here, then, is a field for the practical application of the science of soil physics where close cooperation between the pzactical farmer and the scientist can be mutually beneficial.

COMPARISON OF HUMID AND SEMIARID REGIONS.

Mr. Holmes, previously quoted, makes the following statement in the article mentioned: "In semiarid regions barn manure needs to be used cautiously on unirrigated land." He also mentions "the limitations of the semiarid regions," and finally says: "Unirrigated lands in the arid and semiarid regions labor under such limitations that they can not be compared with other parts of the country in such a manner as crop rotation." These statements, like the others quoted, are in the main true, but the limitations of the semiarid regions are not as restricted as might be inferred from the words quoted. Neither does it seem true to the writer that crop rotation in semiarld regions is so different from crop rotation in humid regions that the two can not be compared. On the other hand, it would seem that a comparison of the problems lnvolved in crop rotation in the humid and in the semiarid regions would be of value in bringing out certain fundamental principles involved in both. The limitations are mainly in the kind and number of crops 
that can profitably be produced in the two regions, and the difference in this respect is not so great as might at first be supposed, as will be seen from an examination of the rotations given below.

The main differecce in the nature of the problems involved, between the humid and the semiarid regions, is that in the humid regions the most important object sought is the conservation of the soil fertility or plant food, while in the arid and semiarid regions it is the conservation of soil moisture. Of course, neither of the.factors can be disregarded in either region, but the relative importance of each is as stated. In other words, the farmer in the humid region is mainly interested in the chemical problems involved, while in arid and semiarid regions the most important problems are those of soil physics.

USE OF BARNYARD MANURE.

What has been quoted from Mr. Holmes concerning the need of caution in using barn manure is true, and it is true because the physical effects produced by an application of the manure are often of greater importance than the chemical ones. It is quite freqnently the case that the bad physical effects of the application more than offset the beneficial chemical ones. But when this fact is recognized and due consideration is given to these physical effects, manure can be applied in semiarid regions with beneficial resuits without danger to the physical condition of the soil In summing up the results of some experiments in the applicatlon of manure to wheat, conducted by the writer in $18 \$ 7$ and 1899 , and publisbed in Bulletin No. 79 of the South Dakota experiment station, the following statements are made:

The farmer should fully understand that while the application of barnyard manure to the soil is certain to have a beneficial effect by adding to the store of plant food, its effect may not be apparent in the results of the first crop after the application, and that the immediate mechanical or physical eflects upon the soil may be either beneficial or detrimental, depending upon the character of the soil, the kind of manure, the time and method of application, the nature of the crop, and the character of the season as to moisture and temperature.

The soil of the farm should be considered a bank in which the surplus resources of the farm, in the form of plant food, should be deposited with the understanding that the surplus can not be withdrawn at once, but is to remain until such time as the conditions are favorable for its utilization. With our light rainfall and retentive soil the danger of loss from leaching is very slight.

From our experience and observation we believe we are warranted in recommending as the surest method of guarding against the possible bad physical effects of the application of the manure that it be applied to land intended for corn instead of wheat; that it be hauled direct from the stable during the late fall, winter and spring, and plowed under in the spring. The corn will be likely to be benefitted, and the wheat crop that should follow the corn will probably be improved as much or more than it would be if the manure were applied directly to that crop.

CROP ROTATION AT SOUTH DAKOTA EXPERIMENT STATION.

The writer has been engaged in experiments in crop rotation at the South Dakota experiment station for the last seven years. Below is given a 
list of the various rotations which have been carried on continuously and systematically for that period and are still under way:

1. Flax, barley, millet, wheat, corn.

2. Wheat, oats, peas (fed), $a$ wheat, roots.

3. Oats, wheat, fallow, wheat, corn.

4. Wheat, barley, peas (plowed), a wheat, corn.

5. Wheat, oats, corn, flax, millet (fed).

6. Wheat, barley, peas (cut), a wheat, corn (fed).

7. Wheat, corn, wheat, oats.

8. Wheat, corn, oats, millet.

9. Wheat, corn, (manured), wheat, oats.

10. Wheat, corn, oats.

11. Oats, fallow, wheat.

12. Barley, millet, wheat.

13. Barley, peas (cut), wheat.

14. IVheat, wheat, fallow.

15. Wheat, wheat, corn.

16. Wheat, fallow.

17. Wheat, corn.

18. Wheat, vetch.

19. Wheat continuously, no manure.

20. Wheat continuously, manured every five years.

21. Wheat continuously, manured every three years.

22. Wheat continuously, manured every year.

23. Wheat seeded to brome grass, brome, brome, flax, wheat, corn.

24. Wheat seeded to brome grass, brome, brome, wheat, corn.

Space will not permit more than the briefest meation of the results of these experiments; but in order to bring about the beneficial effects of a proper rotation uncler aria conditions the following table and explanation are given. The season of 1900 was one of the most unfavorable experienced here for many years. Crops on many neighboring farms were a complete failure on account of the lack of sufficient moisture at the proper time, while the season of 1901 was a fairly favorable one. The yields given are the averages for plats in the aforementioned rotation, grouped together according to the kind of crops which inmediately preceded the wheat and oat crops, respectively.

The following table shows that the average yield of wheat from 30 plats was but 915 bushels per acre for 1900 , while that from the same number of plats in the same rotations was 16.38 bushels for 1901 .

The average yield of oats from 8 plats was 20.69 bushels per acre for 1900 and 47.87 bushels for 1901 . These figures fully bear out the conclusions arrived at from previous considerations, that 1900 was a very unfavorable and 1901 a fairly favorable season; but in spite of the very unfavorable conditions which prevailed in 1900 there were 12 plats out of the 30 that yielded on an average 14.27 bushels of wheat per acre. Four of these had been summer fal

"Where the words "cut," "fed," and "plowed" are used in parentheses after a crop they indicate whether the crop was allowed to mature, and was cut or harvested in the usual manner, was fed off by stock before it reached maturity, or was ploved under for green manure. The word "manured" following a crop indicates that barn manure was applied at time of planting. 
lowed in 1 1,1, , i had raised a crop of corn, 1 a rop of potatoes, and 1 a crop of peas which had been plowed under. The other 18 plats yielded an average of only li..: bushels. Of these, $t$ had raised oats in 18.19, 3 peas, 1 retch, 4 millet, and 6 wheat.

() i the plats of oats raised in 1900 , the ; that followed wheat yielded only $12(; ;)$ bushels per acre, while the three that followed corn produced $2 x .7,5$ bushels per acre.

Yields of wheat and oats in different rotations compared for an unfavorable and a favorable season.

\begin{tabular}{|c|c|c|c|c|c|c|c|}
\hline \multirow[b]{2}{*}{ Rotation. } & \multirow{2}{*}{$\begin{array}{l}\text { Num- } \\
\text { ber of } \\
\text { plats. }\end{array}$} & \multicolumn{3}{|c|}{1900} & \multicolumn{3}{|c|}{1901} \\
\hline & & Straw. & Grain. & $\begin{array}{l}\text { Ratio, } 1 \\
\text { to- }\end{array}$ & Straw. C & Grain. & $\underset{\text { to }-}{\text { Ratio, } 1}$ \\
\hline Wheat after- & & Lbs. & $B u$. & & Lbs. & $B u$. & \\
\hline 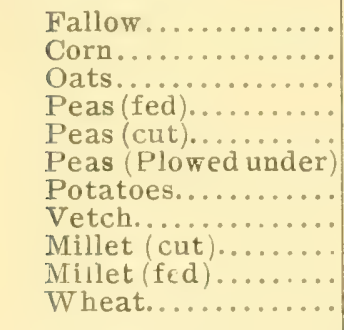 & $\begin{array}{l}4 \\
6 \\
4 \\
1 \\
2 \\
1 \\
1 \\
1 \\
3 \\
1 \\
6\end{array}$ & $\begin{array}{l}2,375 \\
2,280 \\
1,150 \\
1,920 \\
1,645 \\
2,290 \\
2,300 \\
1,620 \\
1,773 \\
1,77 \\
1,415\end{array}$ & $\begin{array}{r}1500 \\
13.91 \\
3.96 \\
7.16 \\
4.66 \\
14.83 \\
13.33 \\
7.16 \\
655 \\
1050 \\
3.60\end{array}$ & $\begin{array}{l}2.64 \\
273 \\
484 \\
4.46 \\
587 \\
257 \\
288 \\
3.77 \\
4.51 \\
281 \\
6.63\end{array}$ & $\begin{array}{l}2848 \\
2,958 \\
2,558 \\
2,660 \\
3,020 \\
2,980 \\
2,870 \\
2,580 \\
2,770 \\
3,020 \\
2,805\end{array}$ & \begin{tabular}{|l|}
15.66 \\
1735 \\
1675 \\
3816 \\
1466 \\
17.00 \\
17.16 \\
15.33 \\
1633 \\
16.33 \\
1546
\end{tabular} & $\begin{array}{l}3.03 \\
2.84 \\
2.54 \\
2.44 \\
3.43 \\
2.92 \\
2.79 \\
2.80 \\
2.83 \\
3.08 \\
3.02\end{array}$ \\
\hline Average... & $\ldots \ldots$ & $\overline{1,86^{7}}$ & 9.15 & 1. & 2,824 & 16.38 & $\ldots$ \\
\hline \multicolumn{8}{|l|}{ Oats after- } \\
\hline $\begin{array}{l}\text { Wheat.............. } \\
\text { Corn... .......... }\end{array}$ & $\begin{array}{l}5 \\
3 \\
-\end{array}$ & $\begin{array}{l}2,046 \\
2.280 \\
\end{array}$ & $\begin{array}{r}1263 \\
2 \times 75 \\
\end{array}$ & 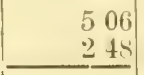 & $\begin{array}{l}2,358 \\
2.343 \\
\end{array}$ & $\begin{array}{r}4814 \\
47.59 \\
\end{array}$ & $\begin{array}{l}153 \\
1.54 \\
\end{array}$ \\
\hline Average & & $\stackrel{2}{-}, 163$ & 2069 & & 2,350 & 47.87 & \\
\hline
\end{tabular}

It will be seen that in the case of the wheat an increased yield of 8.04 busbels was obtained where the wheat followed summer fallow, corn, potatoes, or peas plowed under, while the advantage of raising oats after corn instead of after wlieat was 16.12 bushels of oats. As a bushel of wheat is usually worth from three to four times as much as a bushel of oats, it would have paid better to have raised wheat after corn and oats after wheat in all the rotations.

The yields of both wheat and oats for 1901 were quite uniform and fairly good, although they were undoubtedly 2 or 3 bushels less than they should have been, judging from the growth of straw. This reduced yield was caused by the very hot weather in July. It will be noticed that the heaviest yields of grain were from plats having the lightest growth of straw, and the lightest yields of grain were from plats having the heaviest straw, showing, as has frequently been observed, that where there is a very rank growth of straw the damage from hot winds is usualiy greater than where the growth has not been so luxuriant. There seems to have been no advantage from 
sowing wheat on summer fallow or corn land. In fact, the summer fallow plats fell below the average by 0.72 bushel per acre.

While we should guard agrainst forming too positive opinions upon an experience limited to six years, the evidence so far obtained certainly points very strongly toward the conclusion that, during years when there is a sullicient supply of moisture and a suitable temperature properly distributed throughout the growing season, good yield of wheat may be obtained from our average prairie soils, where the crop is properly put in, without much regard as to the kind of crop the land has raised the preceding season. But when the supply of moisture is leficient for the season, or is not properly distributed, a fair averaged crop can be produced where a suitable rotation is practiced, while partial or total failure will result where wheat is sown after a crop that does not leave the soil in the proper physical condition. In short, it would seem that our soils, after twenty years' continuous cropping, have a sufficient supply of plant food to produce good crops, provided the physical condition of the soil is such that there is enough water to make this supply of food available to the plant.

\section{CONCLUSION}

From the results of the above experiments and from a residence of $t$ wenty years in the semiarid regions, the writer feels waranted in stating the opinion that in no part of the Lnited States is the subject of crop rotations of greater importance than in the arid and semiarid regions.

Crop rotation is only one of the many soil problems that should be worked out in the fieid at the experiment stations and by farmers upon their own farms: and the farmer and the scientist should keep in close touch, so that each may profit by the experience of the other.

\section{Practical Farming.}

The following will form one of the chapters of the book, "Practical Corn Growing," which J. B. Armstrong has written and which will soon be issued. Mr. Armstrong wrote this article a number of years ago and has had time to observe wnether or not he was correct in his contentions, and now, after giving close observation, he intends to put it in the book exactly as he wrote it ten years ago.

How to grow corn and other grains and keep up the fertility of the farm, that it will make a paying crop, ought to be the study of every tiller of the soil. As the world will always have to depend upon the great corn belt of the United States for its supply of the best and most prolific corn seed, and of those varieties that grow the strongest, that resist the drought and hot winds, that best give the most amount of fat-giving quality; this being the case, it is necessary that every farmer do his best that we may not disappoint the world and at the same time reap the rich reward of bountiful crops.

It must be evident to all observing men that the old idea that anyone could farm successfully is fast being abandoned and the people are beginning to learn that preparation for successful farming is as necessary as in any of the professions and that those who are keeping at the front are those who read, think and experiment; that thorough preparation is the first thing that each one should practice. Second a thorough knowledge of the land that they are to cultivate and next the proper seed to be used, especially in corn. The old idea that corn is corn is true, but that the seed grown by the intelli- 
gent specialist with the view in mind that first vitality, sturdy, strong stalk, broad leaf and prolific tendency are the requisites to a paying crop it being evident to every mind that such seed bought from a reliable grower and properly cultivated will do away with the low general yield.

I am thoroughly conyinced that the farm papers, especially in the corn belt, who are adrocating the holding of farmers associations, who are asking for the views of those who are prosperous in that direction are doing a wonderfully good missionary work and ought to be fully sustained with a liberal patronage and the individual farmer, while he must to a certain extent diversify his farming. he should take some one thing as a specialty and do a great amount of work along that line, and then be sure to give your neighbors your experience.

One such farmer with whom we talked but yesterday says: "Five years ago I read your little book. 'Hints on Corn Growing;' and it awakened in my mind a new train of tbought. I procured some improved seed and did my very best to make a good crop and with me the results have been wonderful. My yield for the five years that I have grown it on 80 to 240 acres has made an average for all of these years of 67 bushels per acre. The best year was 5.2 bushels. Now mind, all of my corn is weighed in at the time of gathering, and this year I weighed in from the fielu $4: 00$ bushels and sold the same after being in the crib (it) days and delivered it in the market seyen miles distant and only had $t 1$ bushels of strinkage. I wish all farmers could understand the ralue of thorough sjstem and correct methods as well as I do at the present time. The experience those five years and the efforts $t$ hat I have made are convincing proof to me that one has only to study. read and practice what he may find in those farm papers being so thoroughly scattered throughout our broad land. At least I receive this year three hundred dollars more for the crop of corn that I have to sell than I should have gotten had I not planted reliable corn and that grading at the head. Just such trials and test are what bring out the grand results. Hoping that the above may stimulate many of my readers to a better and stronger effor $\mathrm{t}, \mathrm{I}$ am,

\section{The Sick Farm}

The Delaware Agricultural Experiment Station has recently published Bulletin No. 65 which is unusually suggestive to men who are thinking about fertility, commercial fertilizers, and in general about the methods of increasing crop production. The title- "The Bacteriological Analyses of Soil"might scare some reader and for that reason we have chosen a different heading for our article. We assure them that a bacterium (singular for bacteria). is something that one need not be afraid of and it is well that we should know just how he is helping us.

The bulletin goes on to state that forty-nine analyses of the typical soils of the United States showed as an average result that they had in the first eight inches enough nitrogen to last for ninety crops, enough phosphorus for 500 and potash for 1000 and yet these same soils where the chemist has found so much fertility may under certain conditions become so utterly barren of results to the farmer as to lead him to believe that they are actually devoid of plant food.

The bulletin goes on further to state that the soil at Rathamsted. England, which had been cropped with wheat for fifty years without manure and 
which had consequently been exhausted producing only eight bushels per acre, still contained pbosphorus, in which it was especially exhausted, to last a hundred years to come. We have seen this identical piece of land and saw two or three crops of wheat growing on it. The reason this plot, with a supply of phosphorus to last a hundred years, had become exhausted was simply because it was not in shape to be available for the plants.

You say what has this to do with microbes or bacteria? A very great deal. The trouble with the Rothamsted soil, and the trouble with nearly all so-called exhausted soils, is not that they are deficient in the elements supplied by commercial fertilizers but because they are deficient in vegetable matter-humus-something for the bacteria or microbes to feed on. It is through these that the unavailable forms of plant focd become available. To quote from the bulletin:

"When regetable or animal matter is incorporated with the soil it undergoes a process of decay. In this decay certain products are formed which react upon the insoluble or unzvailable forms of plant food in the soil and render them soluble and available. This iatter decay is brought about through the agency of myriads of bacteria present in the soil."

Here is an idea which may be quite new to many of our readers and yet it explains a good many things that happen in their experience. You must use vegetable matter in order to make your mineral matter available to plants; in other words, to allow digestion and assimilation to gro on. The bacteria of the soil are simply cells and they do work quite similar to what the cells which outline the glands of our own bodies do in the process of digestiou. No matter how much food we may have in our stomachs, or the stomachs of our live stock, it does neither them nor us any good unless it is aigested. If our digestion is out of order, or we take something indigestable into our stomachs, we run to the drug store to get patent medicines. If something is the matter with our land which we do not understand we buy commercial fertilizers. What we need in either case is to get our digestive system at work regularly without tonics or stimulants, and the best tonic you can give your land is vegetable matter. This wili start digestion to work by giving it something to work on and the rest doeth itself. Man suffers from the indigestion; so does the soil. and the worn out soil is simply one that has a bad case of dyspepsia. Give it something for the bacteria to work on and they will increase and multiply and digest even the rocky particles, thus furnishing available plant food. Then give it thorough cultivation so as to enable it to prepare food for the plant, and you have solved the problem.

There is a closer relation between man and the soil than we sometimes imagine. Both of them are liable to indigestion and as the man who has indigeition falls away in flesh because he is using more force than his system is supplying him from day to day so soil that is troubled with indigestion is using up plant food faster than it can be made avaible in the soil and it, like a dyspeptic man, goes into a decline and is said to be worn out. We do not think the good Lord intended the soils of the Mississippi valley to be worn out in ten, fifty, or five hundred years and they will not be unless the farmer allows them to get an attack through the neglect of inficiency of either acute or chronic indigestion. 


\section{A Green Manure Crop}

A subscriber living in Grant township, Ind., writes: "I have a field of fifteen acres. black ground and clay, that needs green manure. The field has been in timothy four years. It is in corn this year and in making some changes in fielts and rotation I find it desirable to plant corn again in this tield. I want a top dressing or covering for the ground through the winter. What would you do, sow crimson clover, cow peas, mommoth clover, rape or rye? Which is best? When and how to sow?"

We could not advise you to sow crimson clover on your fifteen acres that are now in corn. If it were possible to get this clover to grow in the corn, it would be just the thing to sow. It should be sown some time in August, say about the first or 1.jth, but this is a time when we usually have rather dry weather in this latitude and the corn plant takes up about all the moisture in the soil and if the seed germinates at all the plant is likely to die. If the corn could be removed at that time and the soil prepared for the seed, you would likely get a good stand. The same is true of cow peas and soy beans, only there is more liklihood of getting a stand of these two plants. These, however, would not furnish a covering for the ground during the winter. What is needed on this lavi is a nitrogen gathering plant and it is hardly possible for you to grow that this fall. This, however, depends upon the season.

Rape, in this latitude, freezes down in winter and cannot be pastured with safety after freezing weather comes. If five or six pounds of seed be sown sometime during the present month, considerable pasture could be had about the first of September and until freezing or frosty weather. By sowing rye a corn crop can be.grown and some pasture secured from it, but aside from the humus it would form, it does not benefit tha soil any except that it furnisbes a covering during the winter season. We hold that farmers can afford to sow a rye crop or other crop for the special purpose of keeping the ground covered and preventing washing.

You do not say what rotation you desire to use, but if you wish to get this field into clover again you can do so by sowing rye this fall and seeding hearily to clover in the spring and either cutting the rye crop or pasturing it. A good clover and timothy sod can be grown and at the same time pasture the rye field. If it is necessary to plant this field to corn next year, we would let the rye go until it was ten inches or a foot high, plow it down and thoroughly pack the soil before planting. Do not let such a crop get too heavy before plowing it for corn. A heary crop of this kind turned under has a tendency to separate the furrow slice from the subsoil and cut off the rise of moisture.

What would we do? We would sow rye then to clover and pasture the field and not plant to corn next year. This field has already produced five crops that are quite large users of soil fertility. No one can hope to raise maximum crops in this section and follow the above system. Timothy yielding 2500 pounds of hay per acre, removes $81 \frac{1}{2}$ pounds of plant food which in the above case has removed 326 pounds of fertilizer per acre. If another crop of corn is removed from our correspondent's field the total plant food consumed would be 647 pounds par acre. What would we do with this field? We would right-about fice in our treatment and try to regain the vast amount of plant food rumoved from its soil. This field is your bank. The 
Creator placed on deposit there material with which to grow crops for you. He limited the amount of the deposit and trusted you to keep' up the bank account by annual or biennial deposits. Let's not take any more from this bank until a good big deposit has been made. Let's make amends for the past abuses on what the God of nature has stored up for us. Let's be friends of this black and yellow bank by feeding it with chemical fertilizers, by harnyard fertilizers, and by growing these crops which will extract plant food from the air and delve deep in to the lower depositories for that placed there for our use.

\section{Warming Up The Ground.}

It is a common mistake to suppose that the chief reason for digging or plowing the lancl is to separate its particles. On the contrary, we are obliged to add to the labur of loosening up the soil that of recompacting it by harrows and rollers before we can intrust seed or plants to it for a summer's growth. No doubt the plowing and pulveruation facilicates, exmansion of roots aud helps during dry weather, but no healthier, handsomer gromth is obtained by it than we often see on surface not worked at all.

Twenty years ago we learned, partly by accident, that it was not necessary to plow the land deeply in order to secure a maximum crop, and since that time we have never, excepting for purposes of experiment and comparison,turned our land more than four and a half to five inches_deep.

\section{SOIL AND CROPS.}

Perhaps the question will be asked: "What $k$ "nd of land have you and what crop do you grow?" And the answer is a clay loam clay subsoil, and the crops those general in the central states, excepting that we grow some tobacco.

Our land was in part cleared before the year 1800 , and in the past $t$ wenty years our maximum yield per acre thirty-six bushels wheat, eighty five of corn, two bundred twenty-five of potatoes and 1,700 pounds of tobacco; it may thus be seen that our land is far from sterile. We pin our faith to breaking. at the depth mentioned, and then thorough!y working the soil to the very furrow bottom before entrusting seed or plants to it.

Thoroug pulverization of the soil as deeply as broken is of rastly greater importance than the depth of breaking, and we will insure any man a better crop on one half his field, broken four inches deep and cut in perfect condition for the crop, than on the other half broken eight inches deep and fitted for seed with two harrowings.

Did you ever stop to think what the forces of nature are doing year after year to assist vegetation to exist and flourish even in times of extreme drought?

\section{HOW ROOTS GROIV.}

For every blade of grass that grows up to be cropped by the teeth of our stock, cut by the mower or to perish by the frosts of winter there is, comparatively speaking, a root that goes lown into the earth. If we could examine these roots with a glass of high power we would find that they are covered with mouths to take up food for the plant. A p ant root does not bore its way through the soil like a gimlet; neither does it force its way like a nail driven by a bammer. By means of a mi? acid that it secretes from its tip, it 
alissolves its way, and after a start is made its expansive power is sufficient to burst even a stone.

Hence it is not necessary, nor is it even desirable, that the soil in which the plant roots (levelop be as loose as the proverbial ash heap. Now, we go back to the point at which we stopled to speak of the manner in which the roots of the plant make their way through the soil. It is grenerally supposed that most of the plant roots which go deep into the subsoil are seeking for moisture rather than for plant focd, and the supposition seems a reasonable one, for the reason that by far the greater part of fertility in ordinary soils is contained in the upper six inches while the greater part of the soil moisture, of course, lies deeper.

When we break up a tield we break un the connection which nature has established between the top soil, in which the plants get the most of their food, and the subsoil from which they get the moisture necessary to dissolve that food, for plants take all their food in lluid form. If we do not re-establish that connection by use of the barrow, roller and drag, and if we hare a mass of clods and trash at the furrow bottom, the growing crop must suffer even in seasons of moderate drought.

\section{No Money in an Average Crop.}

Whether it be corn, wheat, oats or grass, there is no muney in an average crop. Take the average corn crop for instance, of any state in the Inion. Figure out for yourself the average cost of production which you can do within a few cents, and then take the average price either you will soon learn that you have small rents on the land or the interest on the money invested. The only way that a man can figure out that he is making money on an average price is to count his time at a great deal less than it is truly worth. Farmers must learn in making their estimates to figure the cash value of their labsr. If you have to hire another man to do the work you have, you cannot alford to hire yourself at any less price. We don't care to make the figures but prefer that the farmers make 1 hem, themselves.

The farmer who grows an average crop or less, gets a living and if he gets rent for land or interest for money be must take it off from the price of his own labor. The money is made in growing crops above the average. Thirty bushels of corn per acre will pay expenses, fifty busbels will furnish a nice profit. It costs more to raise a fifty bushel crop than it does to raise thirty: it costs more to husk and it costs more to prepare the ground but the difference is far less than $t \times$ enty bushels of corn per acre.

The average wheat crop of the Uni ed States or particularly of Inwa is not far frow fourtee $n$ lusbels per acre, worth in the market about eight dollars or less, counting two-fifths for the rent. The farmer must furnish the seed, prepare the groud, cut and thresh the crcp. He can very easily see that he is not getting much for his money in a deal of this kind.

The difference between an average crop and a paying crop lies in the adoption of a rotation that will maintain the fertility of 1 he land: second, a better preparation of the seed bed. This requires a little more labor but is more a matter of judgement and clear thinking than of labor. The next diflerence is the better care of the seed. This may cost more but in general costs only a little more time and the use of a good fanning mill in blowing out the light and small grains, and screening out sp:outing grains if such there be. The paying crup costs perbaps a pound of twine more to the acre, four 
cents per bushel for the thresher and a little extra for the hands. The same applies to the corncrop. Given the proper rotatian and cultivated with brains and it costs not a great deal more to grow a paying crop than an arerage crop, until the time of husking and it does not cost twice as much to husk a fifty bushel crop as it does to husk a twenty-five busbel crop.

If the farmer gets it clear in his mind that an average crop never pays and the protit of grain growing is altogether in growing more than an average crop, he will have male a long start in beirig an up-to-date farmer. He will then begrin to study the method of bis ground and its surrounding as to the overflow, draining, etc., he will study to find the crop best adapted to every particular location and the varieties of crop th it will be of most value in a mony way, and yet at the same time preserve the fertility of his land. He will strive to adopt such methods as will insure the largest crop on the least number of acres. He will study the great advantage of improved seels and up-to-date implements for cultivation. He will spend his spare time in reading one of the up-to-date Agricultural Papers, edited by men who are thoroughly and practically in touch with the farmers ard the one in which he will find many communications from farmers who are fast forging to the front. We do not wish you to understand that we mean faucy or book farming. Less acres. more intense farming, better seer's, up-to-date tools, etc. We may put more work on the crop than we get paid for, but as a generai rule if we put more work and especially more bard thinking on a crop we get extra value for additional work and clear thinking.-Wallace's Furmer,

\section{To Prevent Potato Blight.}

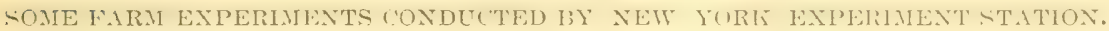

Fur years scientists and investigators hare held that the diseases responsible for far the greater part of what is called "b.ight" are largely preventable, ard bave advocatc the use of borleaux m xture as an easy, cheap and practical remedy for these diseases. But new methods gain a fonthold in farm practice only slowly and after convincing proof of their value, so spraying potatoes for diseases has not been generally practiced.

Experiments conducted at the Geneva station by F. H. t.ull, F. C. Stewart, $H$ J Eustace and $F$. A. Sirrine have shown striking succeis in spraying.

In bulletin No. 241 of that station are given results securcd by five farm. ers in spraying potatoes, and the ligures pri sented sould gn far to convince the most skeptical that the use of bordeaux mixture pays.

These "farmers' test" were carried on by the potato growers without dictation or criticism from the station. each farmer using bis own apparatus, preparing his own mixtures, spraying as many or as few times as he chose and giving his fields jus: such care as seemed best to him. The staticn merely arranged that a sufficient area of each field should be left unsprayed as a check and that the yields on the checks and on equal sprayed areas should be carefully weighed when the potatoes were dug.

In all sixty-one and one-sixth acres of potatoes were sprayed in diflerent parts of the state, and comparisons with the check acres showed an increase in yield, due to the spraying, of $3,7+6$ bushels, or an average of 111 , bushels per acre. The total expense of the spraying was $\$ 2 y+.4$, which suhtracted from the value of the increase at 50 cents a bushel, leaves $\$ 1,57650$ as the total net profit, or $\$ 25.77$ an acre. 
In the second year's test of a ten-year experiment to be carried on by the station in two places there was a gain at Geneva of \& bushels to the acre from three sprarings and of 11s bushels from five sprayings. Cn Iong Island the raius were $3: !$ and $5(i$ hushels per acre from three and five sprayings respectively.

\section{Red Clover And Varieties.}

l'erhaps no plant in this state has more friends than red clover and justly so, as it is a rood yielder, a splendid forage, and a grand soil enricher-on this point I seriously doubt whether its eyual grows within our borders. It has been my foulest dream to establish clover in the rotation on my farm. I hare not yet mecerded in wrowive it to my satisfaction, having made more failures than successes. This I regret for as a legume it was my earliest love. In my dreams I live again amcng the hills of Missouri where I grew

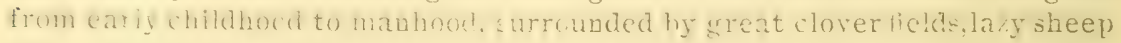
and lowing herds. I sow red clover every year on two of my bluegrass pastures not subject to orerllow. It makes a splendid variety in the pasture. On lanc's subject to overflow I sow alike. This little clover should have more friends. It makes good pasture and an excellent quality of hay, practically free from dust It will stand more overflow of water than any other tame forage plant. I had sereral acres contiuually under water last Nay for twenty days. It came out looking vers sickly, but in a few days regained its ivlor and made a good growtb. furnishing lots of nice pasture the rest of the season.

Brome grass bas no place on the tillable lands of this state. IThy should we spend our time asd energy in the cultivation of a plant which in the end furnishes us a better quantity, a poorer quality, and of a lower feeding value than our old time, honored, frined-timothy? I will not take time to write abont this grass. It's all right. Just throw a dash of red clover seed in the hopper when seeding. Your stock will enjoy it and your land will be benefitted. In regard to the wild bay of the bottom lands. I can truthfully say, I never liked it. It is too coarse and woody. But why w-ite of a dying cause? Its days are numbered. I can as best but sing its requiem

It cannot stand close cutting every year and never gets a chance to reseed itself. Blue grass tco has entrenched itself. It nerer retreats, but with bull log tenacity alvances its skirmish lines year after year and always wins the battle; the big grass must go I tip my hat, I say good bye, without a tear or sigh. Its very abundarce has caused our farmers to partially exhaust the fertility of their soil because it was $n$ t aecesary for them to grow legumes.

"Many" a flower is blown to blush urseen and waste its fragance on the desert air," but barley is one of the unnuals that will be on my list of forage plants as long as I grow stock. 'I like to feed it, my stock, both horses and cattle do well on it. It is especially good for milch cows. It cures a nice light green. It is dustless. My stock clean out their racks more completely whenI feed barley hay than any other forage I have, with the possible exception of sorghum. My stock requires a much less grain ration when $\mathrm{I}$ feed it. I use the common bearded variety. I sow as soon as the frost is out of the grouzd. I cut in the early dough stage, arout the 18 th or 20 th of June. If I hare not grown it as a nurse crop, I plow up the ground and sow to sorghum or millet at once. Barley will cut from two to three tons per 
acre. In many parts of California and the extreme West. Work horses are fed no grain ration, fed absolutely nothing but barley cut in the milk stage.

\section{The Early Man.}

Many farmers are too slow in planting their corn crop in the spring, They are slow in starting to break the soil, in pulverizing the soil: and, last, but not:least, in planting after they are ready. It will alway- pay in the long run to commence breaking the soil as soon as possible after the ground. has settled in the spring. Then you will not be so crowded with your work As a general rule the early man is ahead in plowing as well as in cutting up his corn crop, thus having less langer from early frost in the fall. In the last few years we have tried to plant our corna- early as possible in the spring, so that we would not have to be crowded during haying time. I ast season while we were getting realy to plant we were talking with one of our neighbors about early corn. We told him we preferred planting iuring April, because we had a better crop and it matured earlier. "Well," he said, "I believe I will wait a week or two yet." Before that corn of his was cut up he said that we hit the time and he missedit. ()ur crop did a great deal better than his, which was just over the fence.

Another advantage for us is that our ground is so rich that when corn is planted late it makes very large and tall stalks, while on the otber hanci early corn is not quite so tall. If the early corn is frosted down it will be early enough to plant it over. The first and second plowings make a large per cent of the crop, and the man with the early corncan plow his corn before the hot season comes on, which is so hard on both man and beast. In the early season one clay or week makes a great ditterence with corn, for if a man gets his corn plowed over before the May rains he will have the start of weeds; but on the other hand, should we have a week or more of wet weather before the later corn is large enough to plow. the weeds would have the start in the uncultivated fields.

\section{Value of Rape as a Hog Food}

In the second annual report of the Wisconsin Agricultural Experiment Association the abore subjest is discussel by Mr. ('. E. Jones, of Waukesha county, Wis., who says:

"My experience in using rape as a forage plant for pigs has been growing the last two years, although we have been growing rape for about live or six years. We farmers came to the conclusion that in order to raise hogs the most economical and thrifty way was to grow a bulky, succulent food for them to graze upon. By doing this you will enlarge the frame (or body) of the growing pig and expand his digestive system which will give him the the power to digest grain feed closer.

Pigs fed in this way will make a quicker growth with les grain feed required for one pound of gain. The pig feeding experiments at our experiment station where rape was used as a forage plant will prove this to you. It even took less grain feed per pound of gain where rape was used than where clover was used. My experience has tanght me that in order to produce rape as forage you need other pasture connected with it, such as clover, rye, etc. When you have a variety of feeds which sharpens their appetites. your piss will not be troubled with scours. Two years ago Iscwed one acre of rape 
conncicd with clover pasture. The pigs took as readily to the rape as to the clover. It is best to allow rape to harden or until some of the lower icaven tura brown before pasturing. By feeding at the proper stage you will have better results. The latter part of the season when old pastures are getitug shurt and dry. pe are in need of a foragre crop for pigs. Rape is the very phanc lhat fills the bill of fare. I'sing rape as a forage will gire us an mportunify to change our pigs on diflerent ground. This keeps down disease aud produces cleanliness. Last season I plowed up our old hog yard and sowed rape.

It frotuced enough forage for eight brood sows from September until winter. This is just the food for the brood sow. Pasturing on rape will make her more active and hasten growth of frame. It seems the only true way of making a good mother of her. The kind of soil we have grown rape on is a sandy loam. About two pounds of seed should he sown broadcast per acre. Sow when the grouna is moist or just before a rain so as to give it a start. Fou can sow rape from early spring until late in August. Allow me to urge upon every member of the experiment association who raises hogs to prepare a smail piece of ground, sow it to rape and use it as a pasture crop for the pigs this coming sea-on. Study the results and see if you (lo not reap a benefit and profit from it."

We feel that it is almost impossible to over-emphasize the importance of the rape crop for hor feeding purposes. Tape comes in at a time when other pastures are heginning to dry ul, and (iuring August, September and October if one has a small area inio which he can turn his hogs he will find that it will eflect a very large saving in the amount of grain required.

There are those who a ve had a iittle hard luck while pasturing rape on account of the skin of bogs becoming blistered. Where there is any indication of this taking plate it is an excellent idea to turn the hogs out of the rape at night and keep them out until the crop has become well dried off the next morning. It is entirely practical to sow rape even as late as the first of August, and yet obtain considerable food before the ground freezes in the fall. Of course, in this case there must be moisture in the surface soil to germinate the seed at once, otherwise a crop may not result

There are but few farms but what have some wet or awkward corners .nat cano: the workich a cullivated at the time that other crops are planted. We have ten sow math ines, it but very small and have eujoyed the pleasure of seeing the look of satisfaction and pleasure exhibited by that hog or

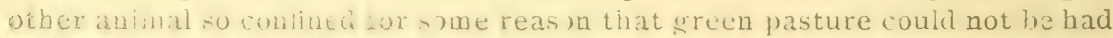
sayiug in our imasinatiua. oh how grood and acceptable and if no other place is available so soon as the wheat, oats or early potatoes are taken from the ground, plough an acre and sow to rape and you will be surprised at the great amount of feed you will get from it before frost will kill it giving your hogs health, fat and comfort and just the time it will be most wanted.

\section{Improving Our Grain Crops.}

We have on several occasions called attention. through these columns, to the fact that graius could be improved by the use of a system of graling that wouli sefiate the plump heary grain from that which is light and shrunken. The alvice riven in tue past has been based on a somewhat extensive practical experience, backe? by result, obtained at a number of experiment sta- 
tions. A world renowned seedsman and plant breeder, Mr. H. L. J. de Vilmorin, in a paper given in the report of the Loyal Agricultural,iociety takes an entirely opposite view of the matter. He says:

In concludiug these notes on selection, it appears advisable to tolich upon a point to which certain people attach great importance, but on which my opinion does not agree with that usually held. I refer to the custon of collecting seeds from some certain part of a plant in preference to another. There is no idea more prevalent in gardening than that of the superiority in seeds from the base of the central stem over those of the top of the same stem and especially over those of the lateral branches. I have made, and had made, experiments on this subject, and I have invariably found no difference among the seeds collected from various parts of the same plant with respect to the proportion of single and double plants obtained. I bare repeated these experiments many times on urnamental plants with respect to the doubling of flowers, on vegetables with respect to the size and yuality of the roots, and on cereals with respect to the yield in weight and appearance of the seed, and I have always found that while individual plants may differ from each other with respect to the transmission of character, yet from the same plant there was a great uniformity of results obtained. The larger seeds produce slightly more vigorous plants in the earlier periods of growth, but do not give any guarantee of ability to transmit superior qualities. When a plant is known to be thoroughbred and its ahility to transmit its own character has been established I should always prefer the smallest seed that came from it, although collected from the part of the plant which is considered the least farorable in the common opinion to the largest seed taken from the part believed to be the most farorable of a plant whose pedigree is less certain.

It would seem to smack of audacity for the average man to set up his opinion on matters of this kind opposing so eminent an authority as Vilmorin and in view of this we can but resort to some data given in a report of the Ontario station that bears directly on this subject. So speaking of bis experiments in barley Prof. C. A. Zivitz says:

The exp riments with the dillerent selections of seed hrley extend over a period of six years, the averare results for the whole priod beingr as follows: Large plump seed, 53.8 bushels of grain per acre, 1.5 tons of straw per acre, and 49.5 pounds of grain per measured bushel; small plump seed 50.4 bushels of grain per acre, 1.5 tons of straw per acre and 488 pounds of grain per measured bushel: abil shrunken seed, 115 bushels of grain per acre. 1.4 tons of straw per acre, and t! 1 pounds of grain per measured bushel. From these results it will be seen that the large plump seed has given an average of nearly 8 bushels per acre more than the shrunken seed and a little over "; bushels per acre more than the small plump seed.

Speaking of the elfect of seed selection in the case of spring wheats, the same experimenter says:

The experiment in seed selection with spring wheat has now been conducted for a period of eight years The average results for the eight years show that large plamp seed produced 2-[.7 bushels of grain per acre, 1.t tons of straw per acre, and grain which weighed 5!) 1 pounds per measured bushel; that the sma!l plump seed produced 15 bushels of grain per acre, 1.3 tons of straw per acre and grain which weighed 58.3 pounds per measured bushel; and that shrunken seed produced 11;.7 bushels of grain per acre, I.2 tons of 
straw per acre, and grain which weighed $56:$ pounds per measured bushel. The plump seed produced grain which was heavier than that produced from shrunken seed the difference being $\delta$ bushels per acre in favor of the former. The large plump seed, therefore, gare practically 30 per cent more grain per acre than that which was produced by the shrunken.

In the case of oats the results were even still more striking than with barley and spring wheat. Professor / zavitz found that during a period of seven years large plump oats gave an arerage yield of 62 bushels per acre, the grain weighing 3.3 .2 pounds per bushel: that medium sizo produced 54.1 bushels per acre, the grain weighing :3:.' pounds per bushel; while the small seed produced $4 \mathrm{i} ; \mathrm{i}$ bushels per acre, the grain weighing 31 s pounds per measured bushel. It will be seen in this case that the large oats produced 15.t bushels per acre more than that produced by the small seed, or an increase of 33 per cent

In the face of results like these, coming from one who is noted for his accuracy in scientific matters of this kind, we cannot but believe that the greater vigor of plants grown from large plump seed in the early part of the season is apparent throughout the entire growing season, and that at threshing time the difference is still as noticeable as ever, viewed from the standpoint of bushels per acre. To our way of thinking it would be just as reasonable to say that the small pis of a litter is of equal merit for breeding purposes as the larger and better proportioned ones, as to say that a small kernel from a wheat head will produce the same results when sown, as a large plump one.

There has been so much said of late as to corn breeding and how to improve corn and it seems those who are working along this line have forgotten the fact that oats and wheat are governed by the same laws of nature and that they will just as readily respond to selection, good soil and cultivation as any other crop grown. The fact is, our wheat, oats and other grains are scrubs, and have not been improved by breeding, although they can be improved as readily as corn by selection and breeding. The fact that on our rich land the average of oats is about 32 bushels to the acre, showing that we are raising scrub oats, and also that we are not raising as much of that as we could if our system of cultivation was better. The same thing bolds good with wheat, and I think in a greater extent. In our stock breeding we realize that like produces like, we know the same thing now about our corn and the same thing is true about our oats, If we sow scrub, light, inferior grain we certainly will raise the same kind as we sow; if we sow grood, heary, perfect seed, we will raise that kind. We can breed good by sowing good seed, as surely as we can raise goud cattle by using good bloocl. Too often we think that anything will do to sow that will come up; if we want to improve our oats and wheat we must sow only the heaviest grain The seed should be run through one of our hest fanning mills, that will save only the very heaviest grains. It may be desirable to run the grain through the second time. It will take some work to thus prepare the seed. In this way you will hare seed that will raise good heary grain. The grain grown from this seed will weigh at least 2 to 4 pounds to the bushel more than the ordinary grain. T'his means an increase of 6 to 10 per cent and instead of our average yield being 32 bnshels to the acre, will be from 40 to 75 for oats and 30 to 40 for wheat. These small gains of a few bushels per acre will easily pay all the taxes or interest upon the farm. 
We hope that the farmers will pay as much attention to improving their seed oats and wheat as they Go to improving their stock, and when they do this they will get better crops and make more money.

We consider the above an object lesson that should be studied by every thinking farmer and if ful!y carried out to the is sst of their opportumities will result in a fine paying proposition.

\section{The Score Card And The Common Farmer.}

VITAL POINTS MISSED IN SCORING CORN VALUE.

Plant Should Not Be Grown For Its Beauty But For Its Meat And Mill Producing Qualities-Some Important Things Overlooked In Score Cards.

That there is a good deal of clap trap about corn judging is not to be denied, and Professor J. T. Willard, director of the Kansas experiment station, writes a timely criticism of the methods employed in some quarters. He says:

"Within the last few years great interest has been awakened in the possibilities of improvement in corn and it has been dem snstrated that by intelligent selection strains may be produced in which protein, starch or fat is made the dominant cliaractcristic. The agricultural colleges are gising marked attention to instruction in corn judging, the agricultural papers exploit the subject, and the hard-headed, practical farisers are beginning to think that there may be sumetbing of value in it.

$\wedge l l$ of this interest is right, and if rightly yielded must bring valuable re. turns but from much that appears it would seem that some of the most vital factors in malime up one's juderment on a variety of corn are almost, and in some cases completely, nerrlected. To rationally juldre corn we must keep) constantly before us the object f $r$ which corn is prounced. Thourh a handsome plant, corn is not grown for ornament: though an ear of corn may be a thing of beauty, beauty is not the aim jn its production By far the greater portion of the corn crop is produced and used directly for feeding purpo:es.

The remainder, not required for seed, is used in certain industries in which one or another of its constituents may possess a special value. For the great majority of farms, therefore, that corn is hast which will proluce the most nutriment per acre. The production of nutriment per acre, considering now the earsonly, will denend upou (1) the weight of the shelled corn peracre and (2) upon its chemical composition. Here, then are the vital points in corn production-yield and composition-yet neither of these appears on the ordinary score card, though, of courss, some of the points considered in scoring have a direct bearing on them.

\section{SOME DOUBTFUL SCORE CARDS.}

"The score cards emphasize points that have much to do with the beauty of the individual ear, but have little or no bearing upon its practical value. Varieties are judged with reference to an arbitrary standard selected as a type, notwithstanding the fact that the type of any variety of corn is altered by a change of climatic relations. It is insisted upon that the ends of the cob must be well covered with grain, that white corn have little white cobs, and yellow corn red cobs, and that the rows must be straight.

"All these are merely fancy points, conformity to which does not insure, or even tend toward a maximum production of nutriment per acre. 1t might even be argued that possession of a cob which is not always filled to the ut- 
most limit is a variety characteristic that is to he sought rather than to be discarled, since it indicates a habit of growth which in certain seasons might be taken advantage of to extend the length of the rows of grain.

"We have seen how quality has been made subservient to fads in respect to color of pure-bred cattle; we see in the judging of poultry how the practical points have been almost surpresed by the fancy in scoring. Should we not take pains to avoid any such degeneration in corn judging?

"Corn judging will lack very much of being on a practical basis until a variety is judged hy its crop producing power tirst. The chemical composition of the corn is the next consideration, after which accessory and fancy points may recieve some attention.

PROTEIN THE THING.

"A variety producing thirty bushels of handsome ears per acre should not receive a moment's farorable consirleration as compared with one producing thirty-five hushels of ears, however deficient in beauty the latter may be.

"Differences in composition cause eyual weights of corn to have dillerent values. Coru beiner deficient in protein and our most abuudant grain, a var iety showing yield equal to another. but hiving a higher percentage of protein, would possess superior value. So, toil, fat; though containing the same elenents as carbohydrates, contain them iu diflerentprovortiou, and weight for weight, posses a bout two and onf-fourth times as great feeling value.

"Fifty-six pounds of corn containing 7 per cent of fat would have about as great feeding value as fifty-cight pouncls of corn containing only 1 per cent of fat, the amount of protein being supposed to remain the same in the two cases.

"'Handsome is as handsome does.' Let us judge varieties of corn on a recorl of past performances, rather than of promise for the future, based merely on good looks."

\section{Utilizing the Wet Places}

There are to be seen a great many wet places in cornfields where a stand of corn is entirely lacking. T'hroughout the corn belt the ground that is liable to remain unproductive on account of wetness will amount to an exceedingly large area. It may seem at present as though it is difficult to do anything to prevent this ground from growing up to weeds during the balance of this season.

While cornfields are generally reluctantly patched, yet we believe that it often pays to patch them. In some cases draws that have dried out are being sown to millet, while in other cases, sorghum is being planted. Of course, these crops are not sown in rows and no attempt is made to cultivate them. The fields are cultivated just the same as if no crops were sown in these places, but the shovels are lifted out while crossing the draws. By the last time the corn is cultivated a little damage may seem to be done by the tramping of the horses, but it is surprising how much fodder may often be obtained in spite of a little rough treatment, especially if the season happens to be reasonably dry after seeding. Where sorghum is used it is advisable to sow somewhat thick, using it at the rate of from 80 to 100 pounds of seed per acre. When sown in this way sorghum makes a most excellent fodder, and will be found to be palatable for all kinds of stock. It is usually cut with the 
mower, altbough in case the crop is not very heavy it may be hanalca with an ordinary self-binder.

Sometimes it is practicable to plant a little early-naturing corn in these low places. As the draws usually run in an ancular direction across the lield it is impossible to check the corn so that it will matcl: the rows, bence it is just about as $\pi$ ell to make no attempt to check it. but to drill in the seed. Of course the shovels must be raised when the field is crossed, and while this corn may not be large when the regular crop is laic! hy, it may be possitse to obain all the way from twenty to forty bushels per acre from these places that would otherwise go to waste. Pride of the North and Lourfellow Dent are varieties that mature in about ninety days so that it is possible throughout a large area of the corn belt to sow even as lace as the 1st of July and yet obtain a reasonably good stand. It is necessary hefore pianting to thoroughly set hack all weed wrowth hy the use of the seed disc. This is hignly important, as but little opjortnnity will bo antinder for cultiration during the growing season.

\section{More Depends on Grass Than Any Other Crop}

The late Senator Ingalis of Kansas, during his long life of public service said many good thinge in an eloutuent and charmin manner. The folluring is taken from one of his notable addresses on Agriculture:

"Next in importance to the divine profusion of water, light and air, those three physical facts which rencler existence wosible. may bo reckmed the universal beneficences of mrass. Lying in the smobine amoner the hattercups and dandelions of May, scarcely hiwher in intelliwence than those minute tenants of that mimic wilderness our earliest recoll wions are of urass: and when the titful fever is ende?. and the foolish wrangle of the market and the forum is closed, grass heals over the scar which our descent into the hosom of the earth has made and the carpet of the infant becomes the blanket of the dead.

"Grass is the forgiveness of nature-her constant benediction. Ficlds trampled with battle, saturated with blood, torn with the ruts of cannon, grow green again with grass, and carnage is forgotten. Streets abandoned by traffic become grass grown, like rural lanes, and are obliterated. forests decay, harvests perish. Howers vanish, but grass is immortal. Beleaguered by the sullen hosts of winter, it withdraws into the impregnable fortress of its subterranean vitality, and emerges upon the solicitation of spring. Sown by the winds, by wandering birds, propagated by the subtle horticulture of the elements which are its ministers and servants, it softens the rude outlines of the world. It invades the solitude of deserts, climbs the inaccessable slopes and pinnacles of mountains and modifies the history, character and destiny of nations. Unobtrusive and patient, it has immortal vigor and aggression Banished from the thoroughfare and fields, it bides its time to return, and when vigilance is relaxed, or the dynasty has perished it:silently resumes the throne from which it had been expelled, but which it never abdicates. It bears no blazonry of bloom to charm the senses with fragrance or splendor, but its homely hue is more enchanting than the lily or the rose, it yields no fruit in earth or air, yet should its harvests fail for a single year, famine would depopulate the work."

\section{The Score Card}

As applied to corn growing and judging in our opinion, an object lesson 
allin: the attention to certain points or rules adopted by certain orcanizafions to be used for the parpose of making award to the person showing an ear of iorn having the most of the points thus described in such Score Card ard has notbing to do with the real value of the corn as to weight, yield or Gedrahilty, time of maturity and therefore has no hearing upon the work of the farmer or the breeder or the honest man who may be at the head of our Lestue stations or state iarms who are working along well delined lines and ..h are felectine frou the best planting under various conditions and cultiahon walsing tests of dillerent combinations of crossing and watching the results in this way they are brought in close connection with nature. The writer has spent many years in such study and fully understands the difliculties under which one must work. It takes time and patience. Prof.J.T. Willara of the Experimental Station of liansas, in an able article publised in the Diovers Journal in which he called attention to the score card and said:

"It has its merits, it should not be forgotten that the most important iactor: yield per acre and chemical composition, are not taken into considcration in the core card. He is inclined to think that tos much attention is being directed to fancy. points and not enough to the points of real value. l'of. Willard says: 'Let us judge varieties on a record of past performance rather than of promise for the future, based merely on good looks.'

Commenting upon this article, one of our contemporaries recently said: "F is true the score cari should emphasize those pints that contribute most to the yield per acre, and yet we cannot help but think that it has contributed to this end as much as any other factir. It has taught us that it is not necessary to have 'homely' looking corn in order to have a large yielding corn, and experiment station offi zers would do well to get into line instead of belittling the efforts of those scientists and workers who have been improving our varieties of corn and teaching others to do the same during the last decade. We though that the blunder made by the Minnesota Station along chis line was sufficient example to prevent its repetition. That station started out to acclimate and improve a variety of corn that would outyield anything on the market. We understand that after a time this object was attained, but so homely was the corn, owing to the neglect of these 'fancy' points in selection that seedsmen could not dispose of it. Consequently this variety has fallen into disrepute, and the workers of that station are now

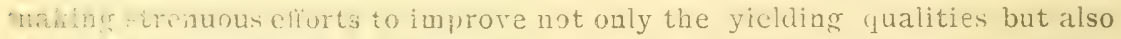
the mitrarlappearance of this corn. This example should stand as a warnlug to inen who are filled with fear over the danver of getting good looking corn that does not produce the pounds per acre"

In reard to the "blunder" made by the Minnesota Station, we wish to say th 1 that station has not made any blunder as theircorn itself has proved. It is yuite evident that our contemporary has been misinformed on this parícular point. It is true that when the Minnesota Station began the improvement of corn varieties by breeding and selection, tnose conducting the work did not lay a great deal of stress upon "fancy points" because they deemed yield por acre of far greater importance than mere outward appearance of the ear, and we most decidedly think they did well. It is also true that now, since yield has been obtained, they are giving some attention to appearance; never, however, do they lose sight of the fact that the past performance records, as regards yield per acre, are of far greater importance than mere fancy points. That great progress has been wade at the Minnesota Station 
in plant breeding is generally known to those informed upon that subject and to read of the great "Blunder" was therefore no little surprise to us. Class Bulletin No. 14, recently written by l'rol Coates I'. Bull, who now has charge of corn improvement at the Minnesota Station, was issued May 10, 1!n1. and amply sets forth the fact that the Minnesota plant improvement las biought forth important practical resilts. Their corn, Minn. No. l:3 for instance, which yielded an averagre of th i bushels during a four years trial, when subsequently selected according to the method in use at that station for tire consecutive years, increased its yielding callacity by 16.3 busbels per acre. In other works, the average yield from $! 4$ to ' $/ 7$ was $4 \$ .1$ bushels, while from "lu to "0:3 the average was lit." bushels per acre. Where the "Bluniler" comes in is diflicult to see when riewing the results from a standpoint of practical utility.

In regard to the fact that seedsmen were unwilling tc handle the corn of the Minnesota Station, we are not aware of any such cases and we happen to be well informed upon that point. In 1903 and 1901 the demand for this "homely" corn was far in excess of the supply, and further, a record from experiment station distributions to farmers in various parts of the state gives, in nearly erery case, a satisfactory report. Asicle from this, the South Dakota Station has found it acceptable fur conditions in that state: Wrisconsin and North Dakota are also cultivating its acyuaintance. To keep a new variety of grain up to its full yielding capacity a system of constant selection must be practiced, and this to be eflectire, must be based upon capacity to yield a large crop. Corn is no exception and will deteriorate rapilly if not selected with care. Unuer common methculs, a bighly bred variety will run down to an inferior quality, and this is jrobably what happens under seedsmen's management.

These in brief, are some of the facts regarding the corn, Minnesota No. 1:3. to which lresumably, our coutemporary refers. It would scem that the Minnesota Station has been grossly misepresentecl, and we are wlal to, at least, in part, correct the error. It is very easy for those of the score card school, to temporarily lose sight of the real value of an ear of corn. The yield per acre is what the farmer wants, and what the farmer wants, is also what the merchant and the manufacturer wants. It is perfectly true that the qualities set iorth in most score cards are to a certain ertent rajuable, but the yield cannot be measured entirely by looks. What do the factory men care ahout looks so long as they can get the yuantity and yuality suited to their purpose: What is there left of the beanty of an ear of corn after it lias been shelled, the cob burned or ground and the grain ground into forty diflerent manufacturing products: Tield is also what the feeder wants, and little does the steer or hog care whether his corn is pretty to look at or is homely so long as he gets quantity and quality.

It is not the purpose here to ridicule or lienounce the score card for it has a purpose and fills it well when in the hands of the proper teacher. But it is the purpose to call to mind the fact that yield is first and of greatest importance. Experience in corn breeding has amply demonstrated that it is not necessarily the good looking ear or the one scoring highest according to the score card that should be used in the improvement of varieties, but the one wnich yields most shelled grain and shows by its progeny that it has a strong prepotency to produce an abundant yield per acre. Let us first look for yield, early maturity and such other practical points as may suggest 
themselves and let appearance and fancy points be of secondary importance.

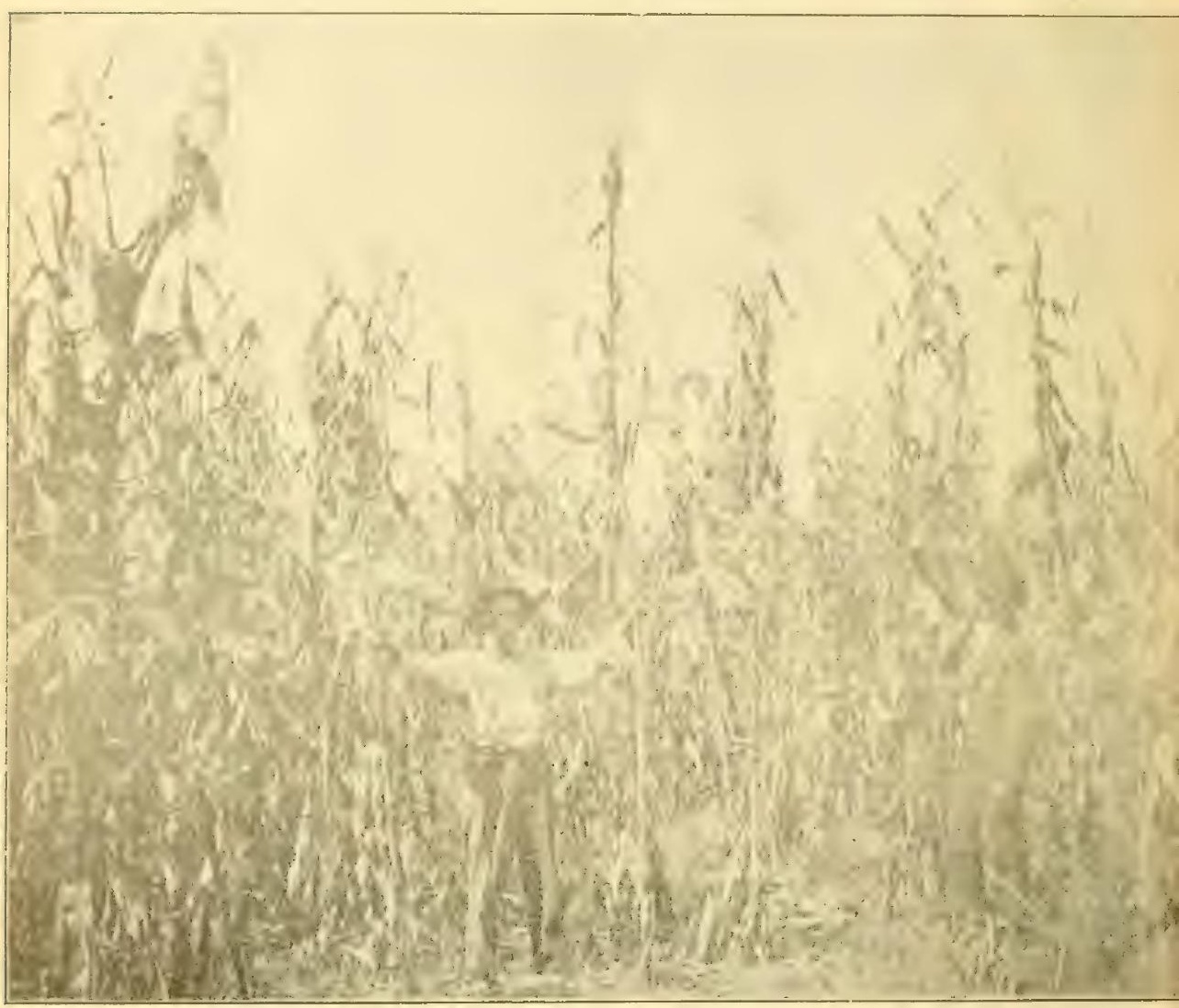

\section{Intense Cultivation}

Cut of a Cornfield that by Intense Cultivation and Improved Seed turned out 140 Bushels per Acre.

In the production of all irinds of crops we must have more intense cultivation. No matter what crop or in what section of the world, the more and better the cultivation the better the crop. It is a recognized fact that intense cultivation and civilization go hand in hand, and we must in truth say the same for the new and better education.

We get our living from the earth and mostly from the farm. By reference to page 23 , you will note what is said in regard to abandoned farms. Had the people who cultivated those farms had the knowledge we possess today and have been able to give those farms the intelligent and intense cultivation as we understand it, there would have been no abandoned farms. The first idea of each farmer is the money consideration. We all want money. But it must not be obtained in such a way thai we rob the soil and make no returns, hence the better knowledge. 
Again there is no place on the farm for the lazy man, and $\mathrm{I}$ am positive that money can be made on the farm if we only work with ener wy in a rational and scientific manner, first planning our work with judgment and thought then carying it out faithfully. We cannot blame those of the past for not doing all they ought, for in their time the people did not possesis the knowledge that we may so easily have at this time.

The agricultural world had not awakened up to the fact that they would be requires to feed the people of the universe, and furnish the sustenance that would support the workers in all the industries of the world, that they were in fact the chosen ones who could and would sustain the mechanic, the merchant, the manufacturer, together with the other thousand of industries. Tollay we face this problem. This being the case how important then must it be that we must be learned in all that pertains to the farm, in such a manner that we may set the best there is from the soil. First, by knowing all that pertains to the soil anil second, all that yertains to intense farming in all its difierent forms. When we have mastered these points we occupy the high pnsition of master of the situation and be able to raise 100 bushels of corn per acre easily. See cut.

We note the fact that in many of the farm papers that there is fear expressed that our boys will not itay on the farm. This may in many cases be true yet it has been our ohservation that the farm boy who has had the right training and surroundings will not forget the old home, and the honorahle rocation of his father, nor the gentle teachings of his mother. But he will

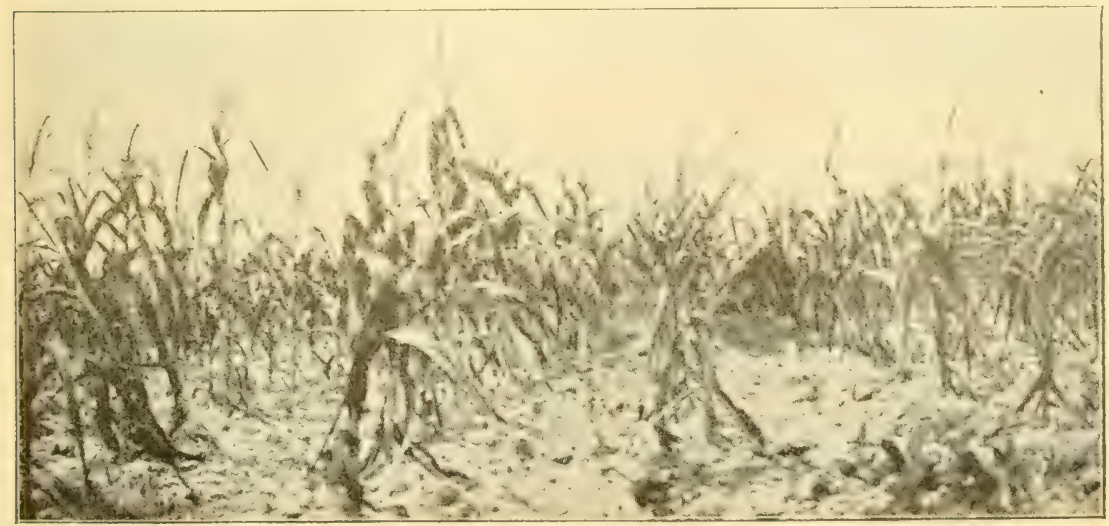

Cut of a cornfield that from poor cultivation, poor seed and lack of know. ledge turned out fifteen bushels per acre.

read and thirst for more and better knowledge. He will seek the agricultural schools in which he will be an earnest worker and when his education is finished he will hasten back to the old farm home with that pride that justly belongs to the honest student. When he will be prepared to impart to others that knowledge that shall and will enthuse and engage others in the great work of progress and the good to be derived from such learning and observation will obviate their many ruined cornfields.

The men who guide our nation today were boys from the farm one day; 
the men who shall take their places in the future are yet on the farm. They are getting the inspiration. and the grand work will roll on: the farm boy will he the one to fill the high positions of our vation, and make farming the most honorable calling amongst the peorle, ani with the latest improved implements and methods of todiy the most profitable rocation that can be found. It raises the standard of morality and intellect, it gives one a life of toil and at the same time enjoyment of yuiet and rest with which no other occupation can compare, for their old and declining days. The art of science is nothing but knowing how to do while that intenseness is but doing with a will what we have to do in a right way. This can and will be done. But let me say to the fathers and roothers who have the first training of the young. do your best to make the home and surroundings as happy and as pleasant as possible for the young children, but do not forget the one fact while you are loing this keep this one point in riew. The farm home, the

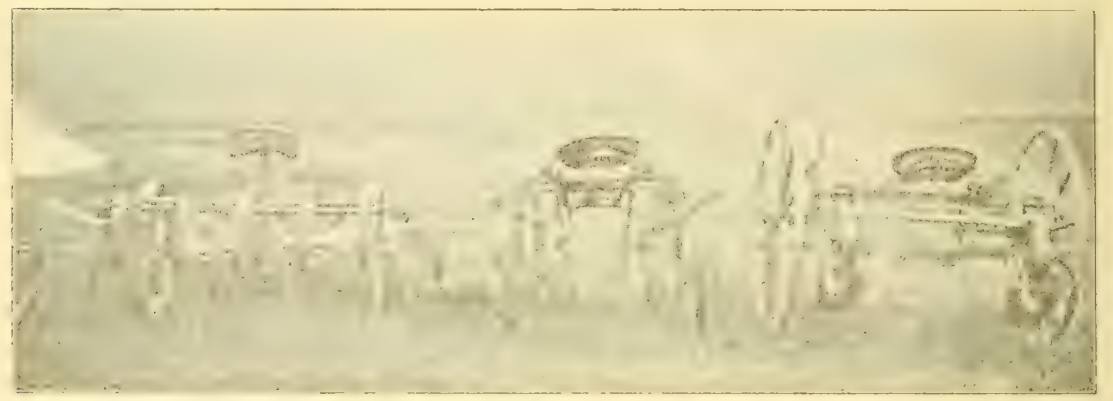

Farm machinery that was used in growing 100 bushel per acre.

farm association and the farm papers have them of the purest type. The first impresion of the youmg and the one that stays with lisem the longest are those of youtl, and will come to their assistance in after life when most needed. Occasionally the son or daughter while ye ung and thoughtless will wander away. yet when they come to that point when they must face the realities of life those early teachings and surroundings come back with double force. Then will the education obtained in their younger days under the above teachings be in great worth in rounding out their happily declining years.

I most sincerely hope that all who have thoroughly studied this volume may and will understand its teachings, and prosper by the same. And I trust at least it will do all such lasting good.

Truly yours,

J. B. ARMSTRONG.

The ripe fruit is dropped at last without violence, but the lightning flashed and the storm raged, and strata was deposited and up torn and bent back and chaos moved from beneath to create and fiavor the fruit and color the flowers on your table today. 
A

Page 15. A twenty acre farm.

Page 31. Agriculture at the head.

Page 48. Acclimation of corn and how to get good seed.

Page 67. Absorption of rainfall.

Page 140. A green manure crop.

Page 97. Adopting corn varieties.

Page 35. Bacteria and the nitrogen.

Page 80. Barren stalks problem.

Page 42 Corn improvements and selection.

Page (i1. Corn planting the foundation of the crop.

Page 63. Corn experiments.

Page 95. Corn breeding or selection.

Page 114. Can small potatoes be profitably used for planting.

Page 117. Cultivation.

Page 13:. Crop rotation, methods and value.

Page 134. Crop rotation at South Dakota experimental station.

D

Page 8. Do not sell the farm.

Page 51. Do not plow too deep.

Page 71. Depth of ploughing.

Page 72 Depth of planting.

Page 74. Distance vetween rows and hills

Page 75 Depth of cultivation

Page 83. Don't get the cultivation too deep.

Page 84. Deep versus shallow cultivation of corn.

Page 102. Does it pay to spray potatoes. (An article of great interest to all.)

Page 116 Distance between plants.

Page 60. Early and late planting.

Page 109. Effect of sprouting

Page 110. Effect on gross saleable yield.

Page 112. Effect on net saleable crop.

Page 129. Essential for the progressive farmer.

\section{F}

Page 69. Fertilizers and crop rotation.

Page 70. Fall ploughing.

Page 76. Frequency of cultivation.

H

Page 34. How legumes improve the soil.

Page 141. How roots grow.

Page 7. Introduction. The feeder and the breeder.

Page 68. Importance of retaining soil moisture.

Page 75. Importance of thorough cultivation:

L

Page 90. Laying corn by.

M

Page 33. Must maintain soil fertility.

Yage 55. Maintaining fertility of the soil,

Page 66. Means of preventing soil washiog.

Pagre 10ti. Manuring potato ground.

Page 11s. Mulching.

Page 15L. More depends on grass than any other crop. 
Page 115. Number of eyes and weight per set.

Page 116. Number of stalks per hill.

Page 142. No money in an average crop.

Page 23. Possibilities of farm education.

Page 5t. Preparing the ground.

Page 59. Planting corn,

Page 71 . Planting.

Page 73. Planting with a lister.

Page 74. Planting with a check rower.

Page 82. Products of a single bill.

Page 89. Possibilities of selection and association.

Page 105. Potato cultivation.

Page 10\%. Planting potatoes. (General directions.)

Page 1:1. Potato diseases and treatment.

Page 122. Potato blight. (State blight or rot.)

Page 123. Potato scab.

Page 137. Practical farming.

Page 1I0. Quantity of seed potatoes per acre.

$R$

Page 67. Rolling or hilly ground.

Page 93. Pegulate the air.

Page 130. Requisites for successful teacher or investigator.

Page I31. Relation of the scientist to the farmer"

Page 144. Red clover and other varieties.

Page 43. Seed corn.

Page 57. Selection and care for seed corn.

Page 65. Some land too poor for profitable corn growing.

Page 109. Seed end versus stem end.

Page 110. Size of seed pieces.

Page 114. Size of seed potatoes.

Page 119. Second crop potatoes.

Page 120. Summary.

Page 127. Soil problems for practical farmers.

Page 130. Study of mechanical characteristics of the soil.

$\mathrm{T}$

Page 9. The farmer's sons and daughters.

Page 11. Thoughts for father and mother on the farm, intelligent and pro. fitable farm knowledge.

Page 128. The study of geology by the farmer.

Page 143. To prevent potato blight.

Page 145. The early man.

Page 149. The score card and the common'farmer.

Page 151. The score card.

Page 138. The sick farm.

Page 134. Use of barnyard manure.

Page 150. Utilizing the wet places.

Page 145. Value of rape as hog food.

W

Page 86. What may be done to increase the vield of corn.

Page 100. What is the farm?

Page 133. Work in crop rotation at experimentalstation.

Page 141. Warming up the ground.

Y

Page 113. Yield from planting different pieces. 


HAlh 5 1906 


\section{LIBRARY OF CONGRESS \\ ||||||||||||||||||||||||||||||||||||||||||||||||||

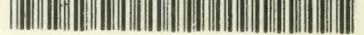

무뎌다 59 